\title{
An overview of the Romanian Gelechiidae (Lepidoptera) summarizing the current knowledge in an updated and annotated checklist
}

\author{
Zoltán Kovács \& Sándor Kovács
}

\begin{abstract}
Summary: This study of the Romanian Gelechiidae fauna deals with 317 species placed in 80 genera arranged in two different lists. The main list comprises 293 species in 78 genera currently accepted for the Romanian fauna, including 286 named and 7 other so far unidentified and probably undescribed species. 269 species (almost $92 \%$ ) were identified from examined material, the other 24 are derived from the literature. 30 species are recorded for the first time for the Romanian fauna: Aproaerema cinctelloides (NeL \& Varenne, 2012), A. suecicella (WolfF, 1958), A. semicostella (Staudinger, 1871), Dactylotula kinkerella (SNellen, 1876), Bryotropha patockai ElSNer \& KARSHOLT, 2003, Aristotelia decoratella (STAUDINGER, 1879), Psamathocrita argentella PIERCE \& Metcalfe, 1942, Ptocheuusa paupella (Zeller, 1847), Metzneria diffusella EnGleRT, 1974, Monochroa tekovella KosoRíN, 2020, Athrips aquila JunNiLAINEn, 2010, Chionodes ignorantella (HERrich-SCHÄFFER, 1854), Gelechia senticetella (STAUDINGER, 1859), G. dujardini Huemer, 1991, Scrobipalpa acuta Povolný, 2001, S. selectella (CARAdJa, 1920), S. gallicella (Constant, 1885), S. nitentella (Fuchs, 1902), S. monochromella (Constant, 1895), S. thymelaeae (Amsel, 1939), Scrobipalpula tussilaginis (STAINTON, 1867), Ephysteris deserticolella (STAUdINGER, 1871), Lutilabria lutilabrella (MANN, 1857), Caryocolum amaurella (HERING, 1924), C. petryi (Hofmann, 1899), C. pullatella (Tengström, 1848), C. blandulella (TutT, 1887), Teleiopsis laetitiae Schmid, 2011, Xenolechia aethiops (HumPHREYs \& WeSTwOOD, 1845) and Stenolechiodes pseudogemmellus Elsner, 1996. There are 6 other new additions, their records were overlooked and not included in the checklists: Apodia martinii Petry, 1911, Monochroa conspersella (Herrich-SchäFfer, 1854), Ptycerata cryptoxena (Gozmány, 1952), Scrobipalpa salicorniae (Hering, 1889), Lutilabria prolata JunNilainen \& Nupponen, 2010 and Agonochaetia terrestrella (Zeller, 1872). Additionally, 78 first records for the different regions of Romania are provided. The previously unknown females of Aproaerema incognitana (GozmánY, 1957) and A. semicostella (STAUDINGER, 1871) are described. A misinterpretation is shown in the literature concerning Bryotropha azovica BIDZILYA, 1996. This species is currently known only from Ukraine (type locality) and Romania, all other records of B. azovica sensu KARSHOLT \& Rutten, 2005 from Turkey, Cyprus, Greece, Bulgaria and North Macedonia are based on misidentifications and represent a different, as yet unnamed, species. An annotation is given for all listed taxa summarizing the current knowledge: the general distribution, the first Romanian record, the regional distribution and a concise enumeration of recent collecting sites based on both material examined and literature. Detailed data are given only for the first Romanian records or those of the regions of the country, and in the case of a few rarely recorded species. The habitats and collecting methods are mentioned, but concise data referring to the biology are only exceptionally given. The 23 species for which no material could be found for examination are treated as in need of confirmation. In a second list are treated 24 species and 2 genera mentioned earlier from Romania, but currently deleted from the checklist, out of this 8 species and 1 genus are now deleted: Aproaerema larseniella (GozMÁNY, 1957), Helcystogramma albinervis (GERASIMOV, 1929), the genus Pectinophora Busck, 1917 including P. gossypiella (SAunders, 1844), Bryotropha plebejella (ZELLER, 1847), Ptycerata furfurella (STAUdinger, 1871), Oxypteryx nigritella (Zeller, 1847), Chionodes nebulosella (HeInEMANN, 1870) and Scrobipalpa salinella (ZelLer, 1847). Replacing the Gelechiidae in the latest Romanian checklist (RÁKosy \& GoIA 2021) with this list is recommended.
\end{abstract}

Key words: Romania, Gelechiidae, faunistic overview, annotated checklist, first records, deleted species.

\section{Introduction}

The Gelechiidae has long been one of the most neglected and poorly known families of the Lepidoptera. During the last 40 years or so there has been a growing worldwide interest in their research resulting in important publications which considerably facilitated and stimulated the studies of regional or local faunas: e.g. the Gelechiidae fauna of Central Europe (ELSNER et al. 1999), the revision of the European Gelechiinae (HUEMER \& KARShOlT 1999, 2010), revisions of the Palaearctic Gnorimoschemini (PovOLNÝ 2002) and of a series of genera, such as Ornativalva GozMÁNY, 1955 (SATTLER 1976), Chionodes HüBNer, 1825 (HuEMER \& SATTLER 1995), Athrips Billberg, 1820 (BidziLya 2005b), Nothris HüBNER, 1825 (KaRsholt \& ŠUmPICH 2015), Megacraspedus Zeller, 1839 (Huemer \& KARSHOLt 2018), Holcophora STAUdinger, 1871 (BIDZILYa et al. 2021), worldwide revisions of Caryocolum GREGOR \& PovolnÝ, 1954 (Huemer 1988), Bryotropha HeinemanN, 1870 (Rutten \& Karsholt 2004; KaRSHOLt \& RUtTen 2005), Mesophleps HÜBNER, 1825 (Li \& Sattler 2012), Agonochaetia Povolný, 1965 (LANDRY et al. 2017), and most recently a commented checklist of the European Gelechiidae 
(Huemer \& Karsholt 2020) and their DNA barcode library (HuEMER et al. 2020).

In Romania the study of the Gelechiidae was neglected for a very long time, in the majority of the publications only a few data were provided, mainly as part of regional faunistic studies (e.g. MANN 1866; Rebel 1911; Popescu-GoRJ \& DrĂGHIA 1964, 1967, 1968; WIESER et al. 2000), catalogues of collections (e.g. Popescu-Gorj 1964; Nemeş \& DĂnilă 1970; KöNIG 1975; Kovács \& Kovács 2001), and rarely records of species (e.g. NeMeş 1968; POPESCU-GorJ 1985a; Kovács \& KovÁcs 1994, 2002a, 2002b). Their number in the checklists reflect the degree of their knowledge: 61 in Caradja (1899), 74 in CARADJA (1901), both which refer to Dobrogea, Muntenia, Moldova and Oltenia, and 174 in CzeKelius (1918) referring to Banat, Crișana and Transylvania. The first recent attempt to gather all published data was the work of POPESCU-GORJ (1984), as part of the checklist of the Romanian Microlepidoptera. Unfortunately it was only a simple list comprising 176 Gelechiidae species. The first critical reassessment of the Gelechiidae fauna in Romania (KovÁcs \& Kovács 2000) became possible only after the publication of the European revisions cited in the first paragraph, it was based on the combination of an overview of the literature together with the study of the material in the L. Diószeghy collection (deposited in the Székely National Museum in Sfântu Gheorghe) and of the authors' collection, which resulted in the identification of 239 species. The previously mentioned study was also the basis of the Gelechiidae family in the last two checklists of the Romanian Lepidoptera by RÁKosY et al. (2003), giving 250 species, and RÁKosY \& GoIA (2021), comprising 260 species.

Over the last two decades an important amount of gelechiid material was collected by the authors, several new studies were published on a continental level (see above) and significant changes have taken place in the systematics of the family (KARSHOLT et al. 2013, HUEMER \& KARSHOLT 2020), however, the latter were not reflected in the latest Romanian checklist (RÁKosy \& GoIA 2021), all these factors justifying the reassessment of the Romanian Gelechiidae fauna.

Abbreviations used:

BIN - Barcode Index Number;

EPPO - European and Mediterranean Plant Protection Organization;

HNHM - Hungarian Natural History Museum, Budapest, Hungary;

LMKK - Landesmuseum Kärnten, Klagenfurt, Austria;

MGAB - „Grigore Antipa” National Museum of Natural History, Bucharest, Romania;

NJ tree - Neighbour Joining tree;

TLMF - Tiroler Landesmuseum Ferdinandeum, Innsbruck, Austria;

ZMUC - Zoological Museum, Natural History Museum of Denmark, Copenhagen, Denmark.

\section{Material and Methods}

To compile this owerview we examined a rich material of more than 9,600 Romanian specimens of the Gelechiidae. The overwhelming majority came from our own collection together with the material in the L. Diószeghy collection deposited in the Székely National Museum of Sfântu Gheorghe. Additionally, a few specimens from the collections of M. Brătășeanu (deposited in the Museum of Brașov), V. Albu, V. Dincă, L. Rákosy and the late V. Vicol were also studied. Some data were kindly provided by M. Stănescu (curator at MGAB), Zs. Bálint and G. Katona (curators at HNHM). The genitalia of almost every species were examined. If the identification based on external characters alone was difficult, e.g. in specimens belonging to the genera Aproaerema and Scrobipalpa, we made as many genitalia preparations as necessary to identify all of the specimens. In the case of 13 species DNA barcode sequences of the mitochondrial COI gene were also obtained. Identification was usually made by the authors, but a couple of species were determined or confirmed by O. Karsholt, P. Huemer and Z. Tokár, all these are mentioned in the annotations. The data obtained were combined with the results of a critical re-evaluation of the literature. Included in the checklist are 7 species which remain unidentified and are probably undescribed taxa. Invasive species are also included.

The systematic list follows the higher classification proposed by KARSHOLT et al. (2013), at generic and at specific level we follow the European checklist of Gelechiidae (HuEMER \& KARSHOLt 2020). Synonyms are not provided as they are listed in that checklist.

An annotation was compiled of all listed taxa summarizing the current knowledge: the general distribution based on literature; occasionally also host-plant data; a summary of the most important literature data for the Romanian distribution, including, if possible, the first record; and a concise list of recent collecting sites based mainly on the examined material, but occasionally also on the latest publications. The regional division of the country follows RÁkosy \& GoIA (2021: 6-7), but we reduced their number from 8 to 7 by disregarding the very small and very heterogeneous region Maramureş and Satu Mare (MM SM) and unifying Maramureş with Transylvania and Satu Mare with Crișana, in view of the natural zoogeographical connections. Detailed data are given only in the case of the first Romanian or regional records, and of a few rarely recorded species. The habitats and collecting methods are mentioned, but concise data about their biology are only exceptionally given. The occurrence of those species for which no voucher material has been examined is considered uncertain and in need of confirmation.

Following the traditions in the case of the first Romanian records and confirmed species, figures of the adults and/or genitalia are provided. The genitalia 
figures are schematic sketches, usually made from free floating genitalia, of which only a few were unrolled.

Finally, we compiled a second list of the previously recorded, but currently deleted taxa. All of these species are also mentioned in the main list by their genera or subfamily if the genus is deleted, but details are only given in this second list.

\section{Results}

In the present study we deal with a total of 317 Gelechiidae species placed in 80 genera, in two lists.

The main list comprises 293 species placed in 78 genera, which are currently accepted for the Romanian fauna, including 286 named and 7 so far not identified and probably undescribed species. We examined voucher material of the great majority of them ( 269 species, almost $92 \%$ ), only 24 are derived from the literature.

The following 30 species are the first records for the Romanian fauna, 28 of them were not mentioned before: Aproaerema cinctelloides (Nel \& VARENNE, 2012), A. suecicella (WolfF, 1958), A. semicostella (STAUDINGER, 1871), Dactylotula kinkerella (SNELLEN, 1876), Bryotropha patockai ELSNER \& KARSHOLT, 2003, Aristotelia decoratella (STAUDINGER, 1879), Psamathocrita argentella Pierce \& MetCalfe, 1942, Ptocheuusa paupella (Zeller, 1847), Metzneria diffusella ENGLERT, 1974, Monochroa tekovella Kosorín, 2020, Athrips aquila JunNILAINEN, 2010, Chionodes ignorantella (HERRICH-SCHÄFFER, 1854), Gelechia senticetella (STAUdINGER, 1859), G. dujardini Huemer, 1991, Scrobipalpa acuta PovolnÝ, 2001, S. selectella (CARADJA, 1920), S. gallicella (CONStant, 1885), S. monochromella (Constant, 1895), S. thymelaeae (AMSEL, 1939), Ephysteris deserticolella (STAUDINGER, 1871), Lutilabria lutilabrella (MANN, 1857), Caryocolum amaurella (Hering, 1924), C. petryi (Hofmann, 1899), C. pullatella (Tengström, 1848), C. blandulella (TutT, 1887), Teleiopsis laetitiae SCHMID, 2011, Xenolechia aethiops (HuMPHREYS \& WeSTWOOD, 1845) and Stenolechiodes pseudogemmellus ElSNER, 1996. The following two species have already been included in the lists, but without evidence that has now been obtained: Scrobipalpa nitentella (FUCHS, 1902) and Scrobipalpula tussilaginis (STAINTON, 1867), thus they are also considered first records.

There are 6 other new additions in the checklist. Although previously reported from Romania in the literature, they were overlooked and not included in the recently published Romanian checklist by RÁKOSY \& GoIa (2021): Apodia martinii Petry, 1911 (GozMÁnY 1958: 264), Monochroa conspersella (HERRICHSCHÄFFER, 1854) (Neacşu \& DrĂGHIA 1973), Ptycerata cryptoxena (Gozmány, 1952) (BIDZILYA \& KARShOlt 2021), Scrobipalpa salicorniae (HerInG, 1889) (HuEMER \& KARSHOLt 2010), Lutilabria prolata JUNNILAINEN \& NUPPONEN，2010 (JUNNILAINEN
\& NuPPONEN 2010) and Agonochaetia terrestrella (Zeller, 1872) (Huemer \& Karsholt 2010).

We confirm from voucher material the presence of 2 species that had earlier been considered to be uncertain: Bryotropha plantariella (TENGSTRÖM, 1848) and Scrobipalpula diffluella (FrEY, 1870) (Kovács \& Kovács 2000: 25, 33).

The identifications of Iwaruna biguttella (DuPONCHEL, 1843) and Psamathocrita osseella (StAINTON, 1860) are considered uncertain and needing confirmation, because the examined voucher material lack the abdomens and so the study of the genitalia was impossible.

Further, there are 7 so far unidentified species mentioned, probably all are undescribed and still are under study: one species each of Aproaerema, Dichomeris, Apatetris, Aristotelia, Chionodes and two of Caryocolum.

Our studies of a large series of Bryotropha azovica BIDZILYA, 1996 collected from the Romanian Black Sea coastal zone revealed that in the literature the name B. azovica covers two different taxa. We conclude that Bryotropha azovica BIDZILYA, 1996 is known only from Ukraine (type locality) and Romania. All other records of $B$. azovica sensu KARSHOLt \& RUtTEN, 2005 from Turkey, Cyprus, Greece, Bulgaria and North Macedonia (KARSHOLT \& RUTTEN 2005: 104; LePIFORUM, accessed 12 April 2020; BOLD Systems, accessed 10 December 2020; HuEMER et al. 2020: supplementary material 2 , NJ tree 16 ) represent a different, as yet unnamed, species. To correct this taxonomic problem a paper is in preparation by $\mathrm{O}$. Karsholt, O. Bidzilya, P. Huemer, Z. Kovács and S. Kovács.

The previously unknown females of Aproaerema incognitana (GozMÁNY, 1957) and A. semicostella (STAUDINGER, 1871) were identified in the studied material and are described hereunder.

The current level of knowledge does not allow us to establish the correct taxonomic status of 5 taxa treated here: Monochroa sepicolella (HERRICH-SCHÄFFER, 1854), Scrobipalpa monochromella (Constant, 1895), Caryocolum pullatella (TENGSTRöm, 1848), Ephysteris diminutella (ZELLER, 1847) and Agonochaetia terrestrella (ZeLLER, 1872). Details are given in their respective annotations.

The material examined also provided data for 78 first records for the regions of Romania: 18 species in Banat, 2 in Crișana, 19 in Dobrogea, 15 in Muntenia, 8 in Oltenia and 16 in Transylvania. RÁKosY \& GoIA (2021) omitted records of 6 species: 3 in Dobrogea and 1 species each in Moldova, Muntenia and Oltenia. These are now included.

A total of 20 records for different regions of the country were deleted because their voucher material was found to be misidentified or incorrect literature data were given: 4 species in Banat, 6 in Crişana, 4 in Dobrogea, 3 in Moldova and 3 in Transylvania. This results in a total of 104 additions and corrections to 
the regional distribution of the Romanian Gelechiidae fauna.

Among the 24 species derived from the literature there are only 3 where the cited publications leave no doubt about their identity, the original descriptions of Mirificarma rhodoptera (MANN, 1866) and Lutilabria prolata JUNNILAINEN \& NUPPONEN, 2010 were based on Romanian type material (MANN 1866: 353; JUNNILAINEN \& NUPPONEN 2010: 28), while Pragmatodes parvulata (GozmánY, 1953) was confirmed by DNA barcoding (HuEMER et al. 2020, supplementary material 2, NJ tree 9). The following 15 species seem to have been reliably identified, but we did not find voucher material for confirmation: Aproaerema patruella (MANN, 1857), Neofaculta ericetella (GEYER, 1832), Dichomeris marginella (FABRICIUS, 1781), Brachmia procursella ReBel, 1903, Monochroa palustrellus (Douglas, 1850), Mirificarma interrupta (CURTIS, 1827), M. mulinella (ZelLer, 1839), Chionodes continuella (Zeller, 1839), Gelechia asinella (HüBNER, 1796), G. basipunctella HERRICH-SCHÄFFER, 1854, G. rhombelliformis STAUDINGER, 1871, Scrobipalpa murinella (DuPONCHEL, 1843), Phthorimaea operculella (ZELLER, 1873), Teleiodes saltuum (ZELLER, 1878) and Pseudotelphusa tessella (LinNAEUs, 1758). All of these must be confirmed in due course by voucher material. The presence of 5 species is doubtful and they certainly are in need of confirmation: Aristotelia brizella (TREITSCHKE, 1833), Ptoheunsa inopella (Zeller, 1839), Apodia martinii Petry, 1911, Aroga aristotelis (Millière, 1876) and Caryocolum klosi (ReBel, 1917). There remains an unnamed Aproaerema sp. that needs further study.

The following genus and 11 species-level taxa were described exclusively or partly from Romanian type material: Carpatolechia CĂPUŞE, 1964; Aproaerema montanata (GozMÁNY, 1957); A. aureliana CĂPUŞE, 1964, currently a junior synonym of $A$. anthyllidella (HüBNER, 1813); Anarsia innoxiella GREGERSEN \& Karsholt, 2017; Ptycerata pudicellus (MANN, 1861); Megacraspedus devorator Huemer \& KARSHOlt, 2018; Megacraspedus similellus HuEMER \& KARSHOLt, 2018; Mirificarma rhodoptera (MANN, 1866); Filatima transsilvanella Kovícs \& Kovács, 2002; Lutilabria prolata JUNNILAINEN \& NUPPONEN, 2010; Carpatolechia dumitrescui CĂPUŞE, 1964, currently a junior synonym of $C$. decorella (HAWORTH, 1812) and Pseudotelphusa istrella (MANN, 1866) (MANN 1861, 1866; GozMánY 1957; CĂPuŞE 1964; KovÁCs \& Kovács 2002a; JunNILAINEN \& NuPPONEN 2010; Gregersen \& Karsholt 2017; Huemer \& KARSHOLT 2018).

Scrobipalpa caliacrae (CARADJA, 1932) was treated as endemic to Romania by RÁkosy (1998: 259), despite being described and mentioned only from Bulgaria (Balchik) and never mentioned from modern Romanian sites, but included in the checklist of the Romanian Microlepidoptera by POPESCU-GoRJ
(1984: 128). Currently it is considered to be a junior synonym of the widespread S. salicorniae (HERING, 1889) (HuEMER \& KARSHOLT 2010: 181). Filatima transsilvanella Kovícs \& Kovícs, 2002 was also considered endemic to the Carpathians by RÁkosY (2013: 70, as Filatina), including it in a list of four 'subspecifically differentiated isolates' although no subspecies was ever described and RÁkosy does not give a subspecific name. The species seems to be widely distributed, subsequently being recorded from the southern Ural Mountains (JUNNILAINEN et al. 2010: 38). Currently none of the named Romanian Gelechiidae species listed here is considered by us to be endemic.

The following 3 invasive species were identified: Sitotroga cerealella (OLIVIER, 1789), Phthorimaea operculella (ZELLER, 1873) and Tuta absoluta (MEYRICK, 1917).

A total of 38 species from Romania have been barcoded, data of 24 of them were already published by Huemer \& Karsholt (2018) and Huemer et al. (2020), one released data was obtained from the BOLD Systems, the remaining 13 species were successfully sequenced during this study.

The genera Pectinophora Busck, 1917 and Ochrodia Povolný, 1966 and 24 species mentioned from Romania previously, but currently deleted from the checklist, are commented on in the second list. 18 of them were misidentifications or there were well-founded arguments that their records are based on incorrect identifications: Dichomeris acuminatus (Staudinger, 1876), Acompsia minorella Rebel, 1899, Helcystogramma albinervis (GERASIMOV, 1929), Pectinophora gossypiella (SAUNDERs, 1844), Thiotricha coleella (CONSTANT, 1885), Bryotropha plebejella (ZelLeR, 1847), B. umbrosella (ZeLLER, 1839), Isophrictis lineatellus (ZeLLER, 1850), Oxypteryx nigromaculella (MiLlière, 1872), $O$. libertinella (ZELLER, 1872), O. nigritella (ZELLER, 1847), Sophronia chilonella (TreitschKe, 1833), Mirificarma flavella (Duponchel, 1844), Chionodes nubilella (ZETTERSTEDT, 1839), Scrobipalpa feralella (ZELLER, 1872), S. suaedella (RICHARDsON, 1893), Ochrodia subdiminutella (STAINTON, 1867) and Sattleria pyrenaica (PetrY, 1904). Of the remaining 6 species recent studies revealed that they were misidentifications of species that had not previously been recorded from Romania. The misidentifications with the correct identifications are: Aproaerema larseniella (GozMÁNY, 1957) with Aproaerema cinctelloides (NeL \& VARENNE, 2012), Ptycerata furfurella (STAUDINGER, 1871) with P. cryptoxena (GozmánY, 1952), Chionodes nebulosella (HEINEMANN, 1870) with a probably undescribed Chionodes species, Scrobipalpa stangei (Hering, 1889) and S. salinella (Zeller, 1847 ) with $S$. salicorniae (HERING, 1889) and $S$. costella (Humphreys \& Westwood, 1845) with $S$. hyoscyamella (STAINTON, 1869). 
Among the above listed deleted taxa the genus Pectinophora Busck, 1917 comprising P. gossypiella (SAUNDERS, 1844) was not included in any of the Romanian checklists, and 7 others were removed from the latest Romanian list (RÁKosY \& GoIA 2021): Aproaerema larseniella (GozMÁNY, 1957), Helcystogramma albinervis (Gerasimov, 1929), Bryotropha plebejella (Zeller, 1847), Ptycerata furfurella (STAUDINGER, 1871), Oxypteryx nigritella (ZELLER, 1847), Chionodes nebulosella (HeINEMANN, 1870) and Scrobipalpa salinella (ZELLER, 1847).

Mainly to avoid any confusion, we list here 4 taxa now deleted from the latest Romanian checklist (RÁkosy \& Goia 2021) because of synonymy: Caulastrocecis CHRÉTIEN, 1931 is a junior synonym of Ptycerata ELY, 1910; Megacraspedus separatellus (FISCHER VON RÖSLERSTAMM, 1843) is a junior synonym of $M$. dolosellus (ZELLER, 1839); Eulamprotes BRADLEY, 1971 is a junior synonym of Oxypteryx ReBel, 1911 and Sophronia ascalis GozMÁNY, 1951 is a junior synonym of $S$. grandii HERING, 1933.

Finally we propose replacing the Gelechiidae in the latest Romanian checklist (RÁKOSY \& GoIA 2021: $53-62,212-221,275,277,282,288)$ with this list.

\section{The annotated systematic list of the Gelechiidae currently accepted for the Romanian fauna}

Gelechiidae Stainton, 1854 is one of the most species rich families of Lepidoptera. The majority of the species are mono- or oligophagous, but both their host-plants and life history strategies are of exceptional diversity. In Europe 110 genera and 880 species are known (HUEMER \& KARSHOLT 2020), in Romania 78 genera and 286 named and 7 unnamed species are recorded.

Anacampsinae Bruand d'Uzelle, 1851 includes the tribes Anacampsini and Chelariini. In Europe 89 species, in Romania 41 are known and one unnamed species is also mentioned.

Anacampsini Bruand D'Uzelle, 1851 is similar with that known from the earlier classifications except the genus Sophronia, which was transferred into Gelechiinae (KARSHOLT et al. 2013). In Europe 67 species, in Romania 32 are known and one unnamed species (Aproaerema sp.) is also mentioned.

Stomopteryx HeInemann, 1870 is a widely distributed Palaearctic genus, in need of taxonomic revision. Currently there are known almost 70 species, from Europe 17 are recorded and 4 from Romania.

Stomopteryx detersella (ZelleR, 1847) is widespread across Europe, North Africa and the Near East (ElsNer et al. 1999: 50). In Romania it was mentioned from Dobrogea already by MANN
(1866: 355), other old records are from Banat (REBEL 1911: 413; RotHSCHILD 1912c: 179), Moldova (NemeŞ \& DĂNILĂ 1970: 183) and Oltenia (STǍNOIU \& ChimişLiU 1993: 43). It is widespread and locally common in Dobrogea, probably more widespread across the southern part of the country than currently known. We collected it on artificial light.

Stomopteryx remissella (ZELLER, 1847) is widespread across the western Palaearctic. It is variable with at least two different phenotypes, possibly a species-group despite the genitalia do not show discernible differences (ELSNER et al. 1999: 50, plate 23 figs 288, 288a; JuNNILAINEN et al. 2010: 55). Barcoded specimens from Europe cluster into 8 different BINs (HUEMER et al. 2020: supplementary files, NJ tree 51). In Romania it was recorded from Transylvania (Sibiu) by CzeKelius (1924: 256) and recently from Dobrogea (KovÁCs \& Kovács 2000: $35)$. We possess a large series from several sites from Transylvania and Dobrogea. The first records for Banat (Băile Herculane, Domogled, 25.VI.1982, 1 đ, legit V. Albu, coll. S. \& Z. Kovács) and Oltenia (Schela Cladovei, $100 \mathrm{~m}, 22 . I X .2019,1$ o, legit \& coll. S. \& Z. Kovács) are published herewith. Our material externally is variable as well, specimens from Transylvania and a few from Dobrogea are similar with those figured by ELSNER et al. (op. cit.), but some specimens from Dobrogea differ, recently two of them have been barcoded (TLMF Lep 27420 from Hagieni, TLMF Lep 27443 from the Măcin Mountains) and clustered into the BIN BOLD:ADR2152 together with specimens from Croatia and France $(S$. remissella $\mathrm{H}$ in HuEMER et al. 2020: supplementary files, NJ tree 51). Further studies are necessary to clarify their exact taxonomic status.

Stomopteryx flavipalpella JäсKH, 1959 is distributed in Portugal, Spain, France, Italy, Germany and Austria (KARSHOLT 2004-2020, accessed 14 April 2020). Corley (2014: 241) assumed that the Portuguese specimens may represent a different species. The barcoded specimens from southwestern Europe cluster into 3 BINs (HuEMER et al. 2020: supplementary files, NJ tree 51). In Romania it was recorded only from the Apuseni Mountains (Rimetea) based on a single specimen (RÁkosy \& WIESER 2010: 42). We collected the species in the same area: Apuseni Mountains, Trascău Mountains, Piatra Secuilor (Rimetea), 5.VII.2000, genitalia prep. 2217/ð/ Kovács, 2 đ, 8 O ; Apuseni Mountains, Gilău Mountains, Scăriţa-Belioara, 900 m, 17.VII.2015,

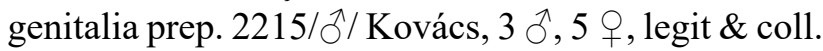
S. \& Z. Kovács, all attracted to light in xerothermic mountain meadows. These records are of a great zoogeographical importance representing the first collecting sites of $S$. flavipalpella eastwards of the Alps. Material collected in Romania has not yet been genetically examined. 
Stomopteryx hungaricella GoZMÁNY, 1957 is local in central Europe and widespread across southern and eastern Europe, the Near East (ELSNER et al. 1999: $50)$. There has been much confusion around its record in Romania. STĂNOIU et al. (1979: plate 30 fig. 3) just figured the species, but not mentioned it in the text. Unlike VICOL (1998: 192) we did not considered this a valid record. Kovícs \& Kovács (2000: 35) and KovÁcs et al. (2002: 77) confirmed its presence with data from Transylvania (Viişoara), but during this study we observed that these records are erroneous, the voucher specimens in fact are $S$. remissella. Later the species was recorded from Dobrogea (Hagieni) by SzÉKelY \& Cernea (2007: 133, det. S. \& Z. Kovács). We examined the following material: Dobrogea, Casimcei Plateau, Dobrogei Gorge, 13.VIII.2001,

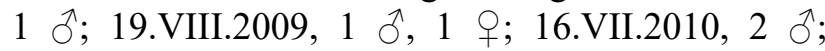
26.IX.2010, genitalia prep. 1780/ठ/ Kovács, $2 \hat{\jmath}$; 18.VI.2012, 1 o; 1.VI.2014, 1 đ, 3 P ; Hagieni forest, 26.VII.2006, 3 ô, 1 o ; 27.V.2007, 1 ก; 2.VII.2015,

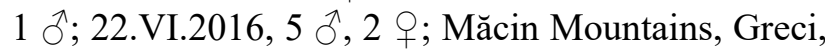
$250 \mathrm{~m}, 23$.VII.2011, genitalia prep. 2228/§/ Kovács, 1 ठో; 15.VI.2012, 1 ô; 1.VII.2015, 11 ơ; 18.VI.2016,

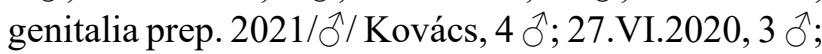
Măcin Mountains, Pricopan Peak, 150 m, 19.VI.2016, 2 đ; Cotu Văii, 25.VIII.2017, genitalia prep. 2218/क्/ Kovács, 5 Ô, 1 क; 16.VIII.2019, 4 กิ, legit \& coll. S. \& Z. Kovács. All were attracted to light in warm and dry meadows. It is widespread but not common in Dobrogea. The symbol for Transylvania must be deleted in Rákosy \& Goia (2021: 60).

Aproaerema DURRANT, 1897 currently comprises also the taxa which in the past were assigned to the genera Lixodessa Gozmány, 1957 or Syncopacma Meyrick, 1925. The latter was recently synonymized with Aproaerema by AARVIK et al. (2017: 71, 163) and accepted by HUEMER \& KARSHOLT (2020) and HuEMer et al. (2020). In Europe 30, in Romania 19 species are known and one unnamed species is also mentioned. Aproaerema larseniella (GozMánY, 1957) is deleted from the Romanian checklist.

Aproaerema patruella (MANN, 1857) is distributed in southern, central and eastern Europe (ELSNER et al. 1999: 50). In Romania there are old records from Sibiu (Czekelius 1924: 256, as Anacampsis) and the Retezat Mountains (GozMÁNY 1953: 184, as Stomopteryx), but the latter was based on misidentification, the specimen in fact is the holotype of Aproaerema montanata (GoZMÁNY, 1957) (GozMÁNy 1957: 116, as Syncopacma). However in the latter paper GozMáNY (1957: 115) mentions again patruella from Romania, but without further data. A record from the Noroieni forest is doubtful (Ardelean 1998: 168, as Syncopacma). The presence of the species in Romania needs confirmation.

Aproaerema coronillella (TREITSCHKE, 1833) is widely distributed in southern and central parts of Europe (ELSNER et al. 1999: 50). In Romania it was recorded from Dobrogea already by MANN (1866: $355)$, later mentioned from most of the country except Muntenia (RÁKosy \& GoiA 2021: 60). Recently it was collected in the Eastern Carpathians, Transylvanian Basin, Apuseni Mountains, Oltenia, Banat and Dobrogea (legit \& coll. S. \& Z. Kovács), in warm open habitats, locally in large number. The collecting data indicate the presence of two generations at lower elevations, but it is single-brooded at higher altitudes.

Aproaerema incognitana (GoZMÁNY, 1957) is locally recorded from Austria, Romania, Ukraine, the southern Ural Mountains in Russia (JUNNILAINEN et al. 2010: 56), Germany, France (LePIForum, accessed 12 April 2020) and Italy (HUEMER \& Wieser 2020: 463). In Romania it was recorded from the Transylvanian Basin (Viişoara) (Kovícs \& Kovács 2000: 35; Kovács et al. 2002: 55, 77). Only a few specimens were collected later. Material examined: Transylvanian Basin, Viişoara, 26.VII.1998, genitalia prep. 1022/ð// Kovács, 2 đ̊; 11.IX.1999, genitalia prep. 1176/ठ̂/ Kovács, 2 đं; 27.V.2000, genitalia prep.

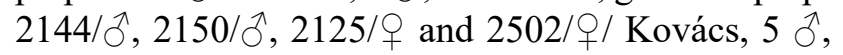
4 ๆ; 27.VIII.2011, genitalia prep. 2490/ふ// Kovács,

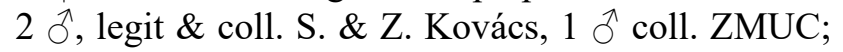
18.V.2002, genitalia prep. 2152/ふ/ Kovács, 1 ठ, legit C. Bere, coll. S. \& Z. Kovács. The collecting data suggest the presence of two generations, adults are on the wing in May and again from the end of July to the beginning of September. Despite in the original description it is mentioned at least one female (GOZMÁNY 1957: 118) the genitalia were not studied. We present it hereunder for the first time. Females (Fig. 1) in average are slightly smaller in size (9-10.5 $\mathrm{mm}, \mathrm{n}=4)$ than males $(10-11.5 \mathrm{~mm}, \mathrm{n}=12)$. The female genitalia (Fig. 2): papillae anales short, as long as segment VIII; apophyses posteriores almost 2.5 times longer than papillae anales; segment VIII short with a semicircular sclerotisation on the middle of the dorsal side of the posterior margin; apophyses anteriores as long as segment VIII; ostium bursae rounded, but its shape looks different depending on its position; antrum conical, connected to segment VIII with long, lateral, ribbon-like processes; posterior part of ductus bursae a gradually tightening sclerotized tube, anterior part of ductus bursae and corpus bursae membranous, without signum.

Aproaerema sangiella (STAINTON, 1863) is widely distributed in Europe and the Near East (ELSNER et al. 1999: 51). In Romania it was only recently recorded from the environs of Satu Mare (ARDELEAN 1998: 168) (doubtful data), Crişana and Transylvania (Eastern Carpathians, Transylvanian Basin) (Kovács \& Kovícs 2000: 37, 2001: 98), the Apuseni Mountains (Rimetea) (RÁKosy \& Wieser 2010: 54). The first records for Dobrogea, Oltenia and Banat are published herewith: 
Dobrogea, Cetatea Histria, 20.VII.2011, genitalia prep. 2212/ふ/ Kovács, 2 ठै; Murighiol, 22.VII.2011, genitalia prep. 2179/ふ/ Kovács, 1 §ं; Oltenia, Hinova, 150 m, 21.IX.2019, genitalia prep. 2496/Q/ Kovács, 1 O; Banat, Băile Herculane, 250 m, 24-25.IX.2019, genitalia prep. $2431 / \widehat{\delta} /$ Kovács, $1 \hat{\sigma}$, legit \& coll. S. $\&$ Z. Kovács. We also examined material from the southernmost part of the Baraolt Mts, Lempes Hill, 29.V.2007, genitalia prep. 2371/ふ/ Kovács, 2 औ, legit V. Albu, coll. S. \& Z. Kovács.

Aproaerema cinctella (CLERCK, 1759) is widely distributed in the Palaearctic region except the northernmost parts (JUNNILAINEN et al. 2010: 57). In Romania it was mentioned from Dobrogea already by ManN (1866: 355, as G. ligulella S. V.) and later

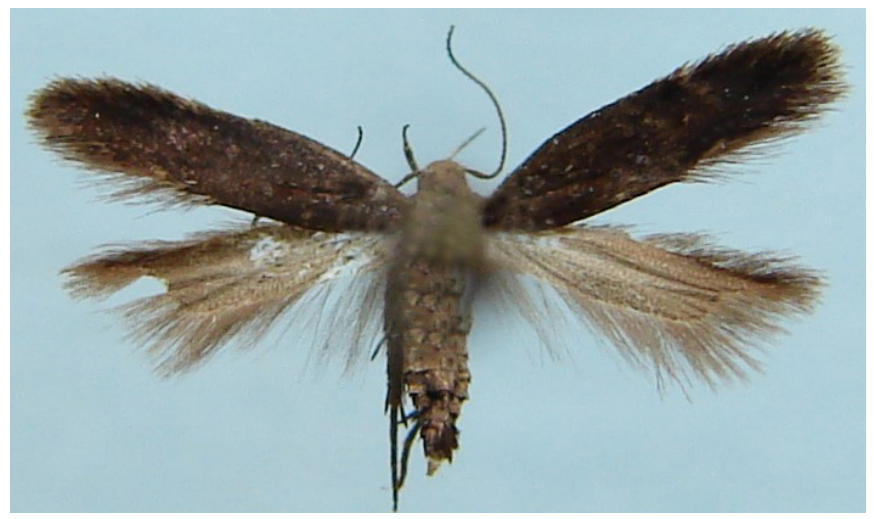

Fig. 1. Aproaerema incognitana (GozmáNY, 1957): adult, female, wingspan $10 \mathrm{~mm}$, Transylvanian Basin, Viişoara, 27.V.2000, legit \& coll. S. \& Z. Kovács.

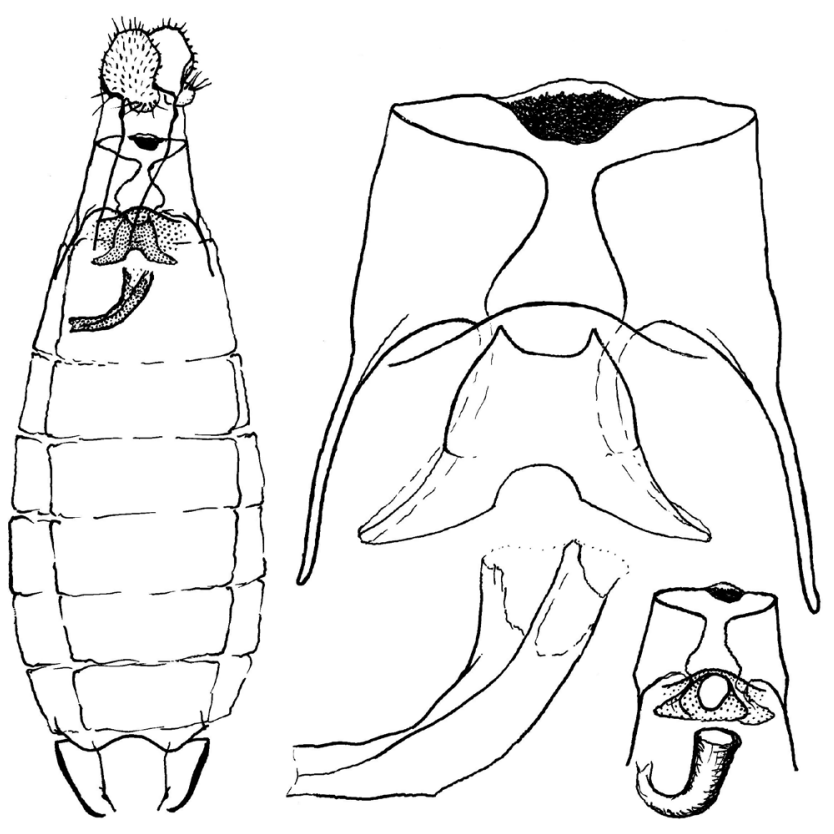

Fig. 2. Aproaerema incognitana (GozmáNY, 1957): abdomen of the female (left), enlarged segment VIII, antrum and posterior part of ductus bursae (right above), genitalia prep. 2502; variation of antrum and posterior part of ductus bursae (right below) genitalia prep. 2125, all in ventral view, same data as Fig. 1. from the whole country (RÁKOSY \& GoIA 2021: 60), but the re-evaluation of the data is necessary, because some of them may refer to the similar A. cinctelloides. Verified material is only from Transylvania: Bicaz Gorge, Harghita and Ciuc Mountains, Giurgeului and Trei Scaune Depressions in the Eastern Carpathians, and Lechința in the Transylvanian Basin, legit \& coll. S. \& Z. Kovács.

Aproaerema cinctelloides (NEL \& VARENNE, 2012) (Figs 3-4) was described from Corsica, currently is known in the southern part of Europe from southeastern Germany, and Czech Republic through Lower Austria and Slovakia to North Macedonia and Greece (Nel \& Varenne 2012: 12; Segerer \& Huemer 2020: 147; ToKáR et al. 2021: 11). First record for

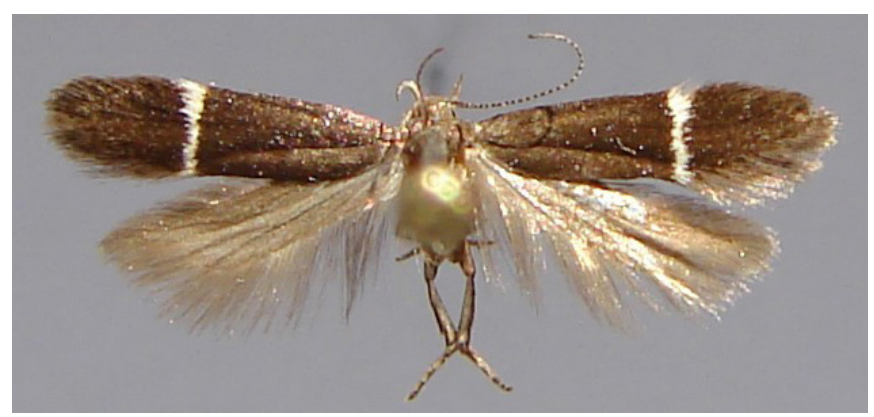

Fig. 3. Aproaerema cinctelloides (NeL \& VARENnE, 2012): adult, male, wingspan $12 \mathrm{~mm}$, Baraolt Mountains, Sfântu Gheorghe, 13.VI.1982, genitalia prep. 2411, legit \& coll. S. \& Z. Kovács.

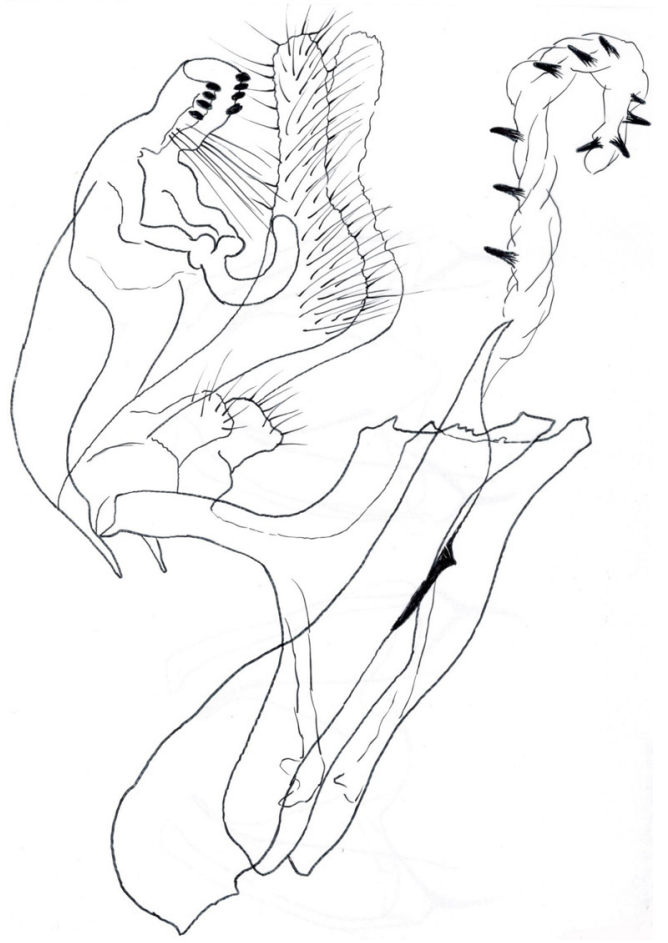

Fig. 4. Aproaerema cinctelloides (NEL \& VARENNE, 2012): free floating male genitalia in lateral view, Perșani Mountains, Vârghiș Gorge, 6-7.VIII.2002, genitalia prep. 2098, legit \& coll. S. \& Z. Kovács. 
the Romanian fauna: Eastern Carpathians, Baraolt Mountains, Sfântu Gheorghe, 13.VI.1982, genitalia prep. 2411/ふ/ Kovács, 1 ठै; Bicaz Gorge, 4.VII.1987,

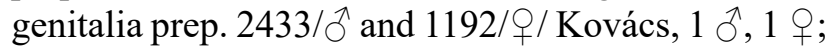
Vârghiș Gorge, 700 m, 6-7.VII.2002, genitalia prep. 2098/ð̊/ Kovács, 1 ô, 1 क; 26.VI.2016, genitalia prep. 2103/ð/ Kovács, 2 औ; Gurghiului Mountains, Brădești, 600 m, 9.VI.2003, genitalia prep. 2097/ कै/ Kovács, 2 ; ; Harghita Mountains, 700 m, Miercurea Ciuc, 13.VI.2003, genitalia prep. 2095/ð/ Kovács, 1 ô; Ciuc Mountains, Racu, Cseretető, $650 \mathrm{~m}$,

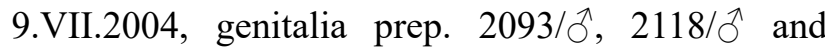

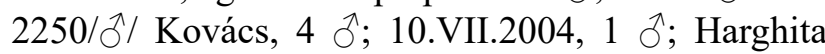
Mountains, Királykútja, 10.VII.2004, genitalia prep. 2099/ठ/ Kovács, 1 đ๋; Ciuc Mountains, Șumuleu valley, 22.VI.2015, genitalia prep. 2119/ $/$ / Kovács, 1 đ̊; Ciuc Mountains, Muntele Păgânilor, 6.VII.2017, genitalia prep. 2116/ठ̂/ Kovács, 3 đ; Apuseni Mountains, Întregalde Gorge, 600 m, 17.VI.2006, genitalia prep. 2114/ð/ Kovács, 2 đ; Transylvanian Basin, Glodeni, 24.V.2003, genitalia prep. 2096/ $/ /$ Kovács, 10 đ̇; Toldal, 28.VII.2007, genitalia prep. 2113/ふ// Kovács, 1 ठૈ; Banat, Dubova, 200-300 m, 17.VI.2021, genitalia prep. 2390/ふ/ Kovács, 1 $\delta$, all legit \& coll. S. \& Z. Kovács; Transylvanian Basin, Miluani, 22.VIII.2002, genitalia prep. 2104/ô/ Kovács, 1 ô, legit C. Bere, coll. S. \& Z. Kovács. It seams to be more widespread in Transylvania than A. cinctella. In the Bicaz Gorge it flies in the same habitat and period than A. cinctella and A. azosterella.

Aproaerema wormiella (WOLFF, 1958) was only locally recorded from Italy, Germany, Austria, Slovakia, Hungary, Latvia, Denmark, Sweden, Finnland (ElSNER et al. 1999: 51), Estonia (AARVIK et al. 2017:71) and Ukraine (BIDZILYA \& BUDASHKIN 1998: 13). In Romania it was known from the Transylvanian Basin (Lechinţa, 31.VIII.1996,

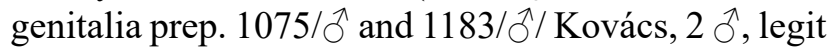
\& coll. S. \& Z. Kovács; Bărăi, Cluj County, steppe habitat, 440 m, KLM Lep 06006, legit C. Wieser, coll. LMKK) (KovÁcs \& KovÁcs 2000: 37; HUEMER et al. 2020, supplementary material 2, NJ tree 10; BOLD Systems). Only a few additional specimens were collected later from the Transylvanian Basin (Glodeni, 26.VIII.2011, 1 §), the Apuseni Mountains (Trascăului Mountains, Rimetea, 5.VII.2000,

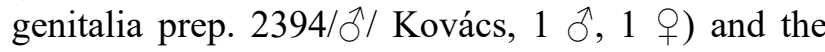
Eastern Carpathians (Gurghiu Mountains, Brădeşti, 600 m, 16.VIII.2011, genitalia prep. 2117/ふ/ Kovács, 1 đ; Trei Scaune Depression, Mestecănișul de la Reci, 4.VIII.2012, 2 đ; Ciuc Mountains, Șumuleu valley, 800 m, 20.VI.2018, genitalia prep. 2112/ð/ Kovács, 1 §), legit \& coll. S. \& Z. Kovács.

Aproaerema azosterella (HERRICH-SCHÄFFER, 1854) has for a long time been confused with other species of the genus, due to its unrevised type material. The taxonomic status and the distribution of the species was only recently clarified and proved to be distributed in southern Europe, southern parts of western and central Europe, Ukraine, the southern Ural Mountains in Russia and Morocco (BIDZILYA \& KARSHOLT 2013: 77, 82). The species was treated as Syncopacma sp. 1 by ELSNER et al. (1999: 52) and subsequently by Kovács \& KovÁcs (2000: 37). In Romania it was recorded from Satu Mare (Ardelean 1998: 168) (doubtful data) and the Eastern Carpathians (Bicaz Gorge) (Kovács \& Kovács op. cit.; BidzILYA \& KARSHOLT op. cit.). Recently it was collected also from other Transylvanian sites (Apuseni and Gurghiu Mountains), legit \& coll. S. \& Z. Kovács.

Aproaerema ochrofasciella (ToLL, 1936) is distributed in eastern and northern Europe, very local in central Europe, extending eastwards through south-western Siberia to the Russian Far East (JunNILAINEN et al. 2010: 58). In Romania it was only recently mentioned from the Transylvanian Basin (Glodeni), the southern part of the Eastern Carpathians (Baraolt Mountains) (Kovács \& Kovács 2000: 37) and Dobrogea (Măcin Mountains) (WIESER et al. 2000: 33). Recently it was also collected in the Apuseni Mountains (Turda Gorge) and in the Bodoc Mountains in the Eastern Carpathians, legit \& coll. S. $\&$ Z. Kovács. The record for Dobrogea was omitted by RÁkosy \& GoiA (2021: 60).

Aproaerema taeniolella (ZELLER, 1839) is widely distributed in Europe and the Near East (ELSNER et al. 1999: 51; BidZILYA \& BUDASHKIN 1998: 13). In Romania it was recorded from Transylvania (PÁveL 1898: 18; RothSCHILD 1912a: 29; CZEKELIUS 1918: 45; DiósZeghy 1930a: 285; PoPescu-Gorj 1964: 36; SzABÓKy 1994: 349; Minuț 1998: 74; Kovács et al. 2002: 55), Moldova (CARAdJA 1899: 205; NeMEŞ \& DĂNILĂ 1970: 183; RÁKosY et al. 1998: 21) and Oltenia (RÁKosY \& GoIA 2021: 60). Recently it was collected only in the Transylvanian Basin (Viişoara, Toldal), legit \& coll. S. \& Z. Kovács.

Aproaerema montanata (GoZMÁNY, 1957) is known from Romania, France, Italy, Switzerland, Ukraine, Turkey (ElSNER et al. 1999: 52; BIDZILYA \& BudASHKIn 2009: 19; KARSHOLT 2004-2020, accessed 12 April 2020), Croatia, Bulgaria and Greece (Z. TOKÁR pers. comm.; BOLD SySTEMS). The species was described based on a single male specimen collected in the Retezat Mountains, 1200 m, 28.IX.1927, legit L. Diószeghy (Gozmány 1957: 115). Later it was recorded from the Transylvanian Basin (Toldal) and the southern part of the Eastern Carpathians (Perşani Mountains) (Kovács \& Kovács 2000: 37) and without locality data by KovÁcs \& Kovács (2001: 98, coll. L. Diószeghy). Recently it was collected in the Apuseni Mountains (Rimetea, Scăriţa-Belioara) and the Southern Carpathians (Vâlcan Mountains, Vaidei Gorge, 13.V.2016, genitalia prep. 2168/ठึ/ Kovács, 
1 ठิ; Dubova, 200-300 m, 23.IX.2019, genitalia

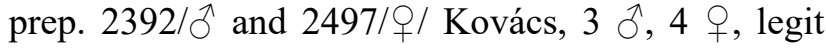
\& coll. S. \& Z. Kovács). The collecting data indicate the existence of two generations: adults are on the wing from May to June and again in August and September. The specimens of the first generation are larger (males 13-13.5 mm) than those of the second one (males 11-12.5 mm, females $11-12 \mathrm{~mm}$ ). The sexual dimorphism is evident, the males have costal and tornal white spots only, while the females possess a white transverse fascia at tornus. There are the first records for Oltenia and Banat.

Aproaerema albifrontella (HEINEMANN, 1870) is distributed from northern Italy through central Europe, the Baltic countries, Ukraine and the southern Ural Mountains to southern Siberia, Mongolia and China (JunNILAINEN et al. 2010: 58). In Romania it was mentioned from the Retezat Mountains (DiószeGHY 1930a: 285) and Crişana (Ineu) (CĂPuşe \& Kovács 1987: 61; Kovács \& Kovícs 2000: 37, 2001: 98). CĂPUŞ̧ \& Kovács (1987: 62) also recorded Anacampsis ignobiliella [sic!] HeInEmann, 1870 from the Retezat Mountains, ignobilella currently is a junior synonym of $A$. albifrontella (HUEMER \& KARShOLT 2020: 72). The latter record was not confirmed during the revision of the Gelechiidae in the L. Diószeghy collection by Kovács \& Kovács (2001: 98), the re-examined specimen proved to be Bryotropha similis (STAINTON, 1854). Recent data are from the Apuseni Mountains (Rimetea) (RÁkosy \& WIESER 2010: 54). We collected it in the same site.

Aproaerema cincticulella (BRUAND, 1851) is distributed throughout the continental Europe, Turkey, the Near East and Siberia (JunNILAINEN et al. 2010: 59). There are 4 old records from Romania: in Transylvania from Sibiu (CzeKelius 1918: 45) and Cetatea de Baltă (KovÁcs \& Kovács 2001: 98), in Banat from Băile Herculane (20.VI.1926, legit D. Czekelius) (ReBel 1927: 118) and in Moldova from Câmpulung (PeIU \& Nemeş 1970: 59). Recently it was mentioned only from the Perșani Mountains (Bogata forest) by ALBU \& ALBU (2018: 20). The records from Ineu (Crișana) and the Retezat Mountains (CĂPUŞE \& KovÁCS 1987: 61) have been based on misidentifications, the specimens in fact are $A$. cinctella (Kovács \& Kovács 2001: 98). Consequently the symbol for Crişana must be deleted in RÁkosy \& GoIA (2021: 60).

Aproaerema vinella BANKES, 1898 is locally distributed in almost all Europe and the Near East (ELSNER et al. 1999: 51). Its first mention in Romania was made from the Retezat Mountains by GozMáNY (1953: 184, as Stomopteryx biformella SCHÜTzE, 1902). The record from Ineu (Crișana) by CĂPUŞE \& Kovícs (1987: 61) was a misidentification (Kovács \& Kovács 2000: 37). The same Kovács \& Kovács (op. cit.) recorded it from the southern part of the Eastern Carpathians (Mestecănişul de la Reci, Baraolt Mountains) and RÁKOSY \& WIESER (2010: 54) from the Apuseni Mountains (Rimetea). Recently it was collected in several sites, locally in large number, from the Eastern Carpathians, Apuseni Mountains, Transylvanian Basin and Banat (Băile Herculane, 250 m, 16.VI.2021, genitalia prep. 2491/ð// Kovács, 2 ○, legit \& coll. S. \& Z. Kovács). It is the first record for Banat.

Aproaerema linella (CHRÉTIEN, 1904) is locally distributed throughout the central part of Europe from France to Romania (ELSNER et al. 1999: 51) and Ukraine (BIDZILYA et al. 2012: 25). In Romania it was recorded from Moldova (NemEş 1974: 208), Muntenia (RÁKosy \& Goin 2021: 60) and Dobrogea (Kovács \& Kovács 2000: 39), but the latter was misidentified, the re-examined male genitalia proved to be $A$. semicostella (StAudinger, 1871). Data from the environs of Satu Mare are doubtful (ARDELEAN 1998: 168). Recently the species was collected also in the Apuseni Mountains (Gilău Mountains, ScărițaBelioara, $900 \mathrm{~m}$, 17.VII.2015, genitalia prep. 2185/ふ/ Kovács, 2 Oૈ, 1 + ; 1.IV.2017, genitalia prep. 2149/ð/

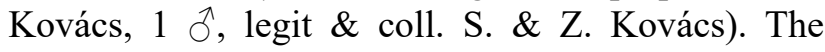
collecting data of the few available specimens indicate the existence of two generations. It is the first record for Transylvania, the symbol for Dobrogea must be deleted in RÁkosy \& Goia (2021: 60).

Aproaerema suecicella (WOLFF, 1958) (Figs 5-6) is distributed from Western Europe to Central Asia (ElSNER et al. 1999: 52). Barcoded European specimens cluster into two geographically separated BINs (HuEMER \& KarShOLT 2020: 121). First record for the Romanian fauna: Dobrogea, Hagieni forest, 17.IX.2004, genitalia prep. 2480/ふ/ Kovács, 2 ठૈ; Cotu Văii, 25.VIII.2017, genitalia prep. 2477/ô/ Kovács, 1 đ̂, legit \& coll. S. \& Z. Kovács. Material collected in Romania has not yet been genetically examined.

Aproaerema captivella (HERRICH-SCHÄFFER, 1854) is distributed in scattered localities in Europe (ELSNER et al. 1999: 52). In Romania it was recorded from the Retezat Mountains (DiószeGHY 1930a: 285, as Anacampsis sarothamnella ZELLER, 1868), but according to GozMÁNY (1953: 184) the record was a misidentification, the specimen collected by L. Diószeghy on 13.VII.1922 and identified as A. sarothamnella by T. Uhrik-Mészáros in fact is Stomopteryx biformella SCHÜTZE, 1902, currently a junior synonym of $A$. vinella. However, GozmánY (1957: 124, 1958: 178) mentions captivella from Romania again, but without further details. POPESCUGORJ (1984: 129) included the species in his list. Later it was recorded from the Transylvanian Basin (Viişoara) by Kovács et al. (2002: 55). Recently it 
was collected also in the Apuseni Mountains (Turda Gorge), legit \& coll. S. \& Z. Kovács.

Aproaerema semicostella (STAUDINGER, 1871) (Figs 7-9) is distributed in southern Siberia (Buryatia), the Caucasus, Azerbaijan, Kyrgyzstan, Turkey, Pakistan and in Europe only in Russia (Lower Volga, southern Ural Mountains) and southern Ukraine (BIDZILYA 2002: 231; JUNNILAINEN et al. 2010: 58; BOLD Systems, accessed 10 December 2020). First record for the Romanian fauna: Dobrogea, Grindul Chituc, Vadu, 28.VIII.1999, genitalia prep. 1062/ $/ /$ Kovács, 1 ภं; 28.VII.2000, genitalia prep. 2211/ $/$

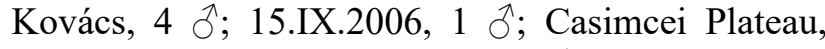
Dobrogei Gorge, 26.IX.2010, 1 §ో; 18.VI.2012, 1 đ; 29.IV.2013, genitalia prep. 2079/§/ Kovács, 1

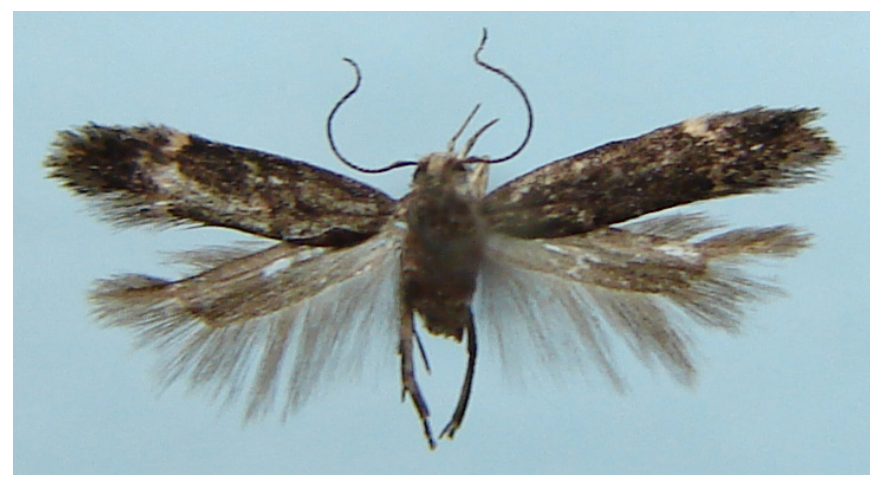

Fig. 5. Aproaerema suecicella (WoLfF, 1958): adult, male, wingspan $9 \mathrm{~mm}$, Dobrogea, Cotu Văii, 25.VIII.2017, genitalia prep. 2477 , legit \& coll. S. \& Z. Kovács.

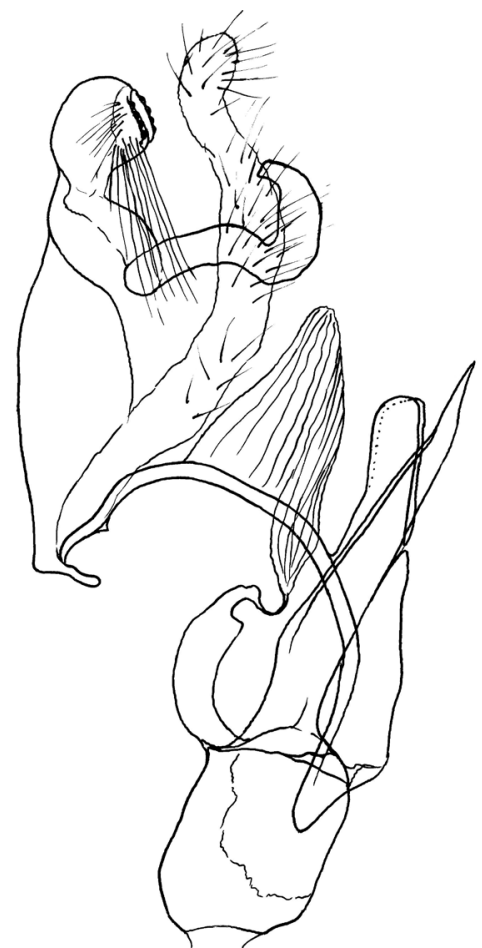

Fig. 6. Aproaerema suecicella (WoLFF, 1958): free floating male genitalia in lateral view, Dobrogea, Hagieni forest, 17.IX.2004, genitalia prep. 2480 , legit \& coll. S. \& Z. Kovács.

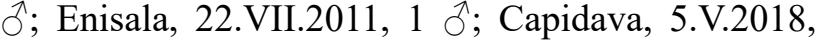
genitalia prep. 2503/ᄋ/ Kovács, TLMF Lep 27442,

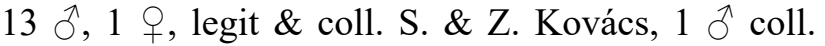
TLMF; Grindul Chituc, Periboina, 29-30.VIII.2012, 2 đ, legit R. Kis \& I. Kovács, coll. S. \& Z. Kovács. The specimen collected in 1999 was misidentified and published as Syncopacma linella by Kovícs \& KovÁcs (2000: 39) (see above). The species reaches the western limit of its known distribution in Dobrogea. A recently sequenced Romanian specimen clusters into the BIN BOLD:AAW5087 together with specimens from the southern Ural Mountains and Kyrgyzstan (BOLD Systems, accessed 10 December 2020). According to BIDZILYA (2002: 231) the species differs from all other Aproaerema in having white head, labial palps and tegulae, while the white fascia at the base of the costal edge of the forewing is often reduced to a small spot or not present at all, and the female is not known. The Romanian material presents the same variations of the markings that Bidzilya mentions, but only the specimens which have large white wing markings at the base of the costal edge have white tegulae. Further, the specimens which have white markings at the base of the forewing also have a conspicuous black line in the basal half of the fold, the latter is indistinct in specimens which lack white markings. The unique female specimen possesses large white wing markings and at $3 / 4$ of the forewing a distinct white transverse fascia curved towards apex, the latter is indistinct in the males or there are only costal and tornal spots (Fig. 7). We present the female genitalia (Fig. 9) hereunder for the first time: papillae

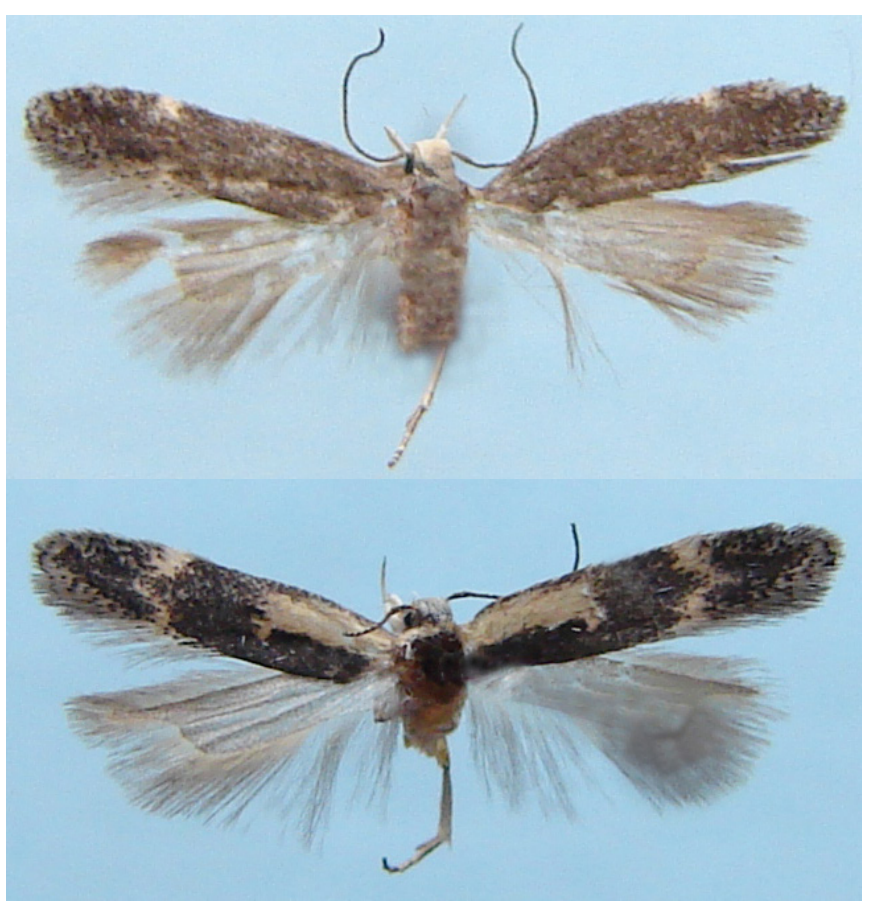

Fig. 7. Aproaerema semicostella (STAUDINGER, 1871): adult, male, wingspan $10 \mathrm{~mm}$, Dobrogea, Grindul Chituc, Vadu, 28.VIII.1999, genitalia prep. 1062 (above); adult, female, wingspan $10 \mathrm{~mm}$, Dobrogea, Capidava, 5.V.2018, genitalia prep. 2503, legit \& coll. S. \& Z. Kovács (below). 
anales short, as long as segment VIII; apophyses posteriores almost 2.5 times longer than papillae anales; segment VIII long with a V-shaped excavation on the middle of the dorsal side of the posterior margin; apophyses anteriores slightly shorter than

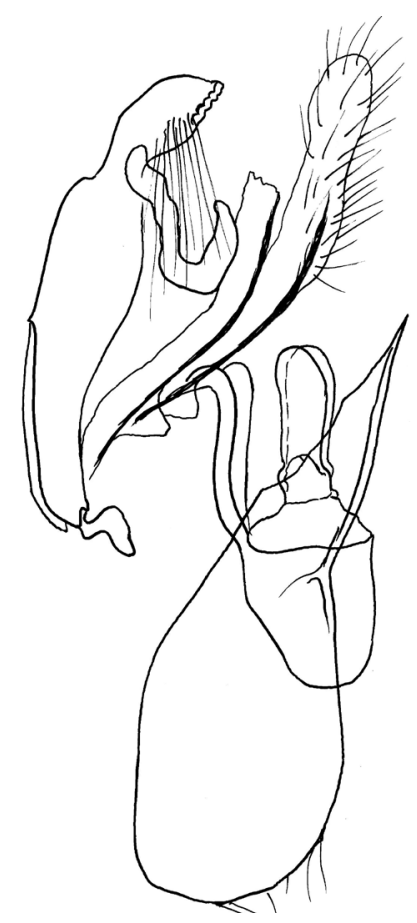

Fig. 8. Aproaerema semicostella (STAUDINGER, 1871): free floating male genitalia in lateral view, Casimcei Plateau, Dobrogei Gorge, 29.IV.2013, genitalia prep. 2079, legit \& coll. S. \& Z. Kovács

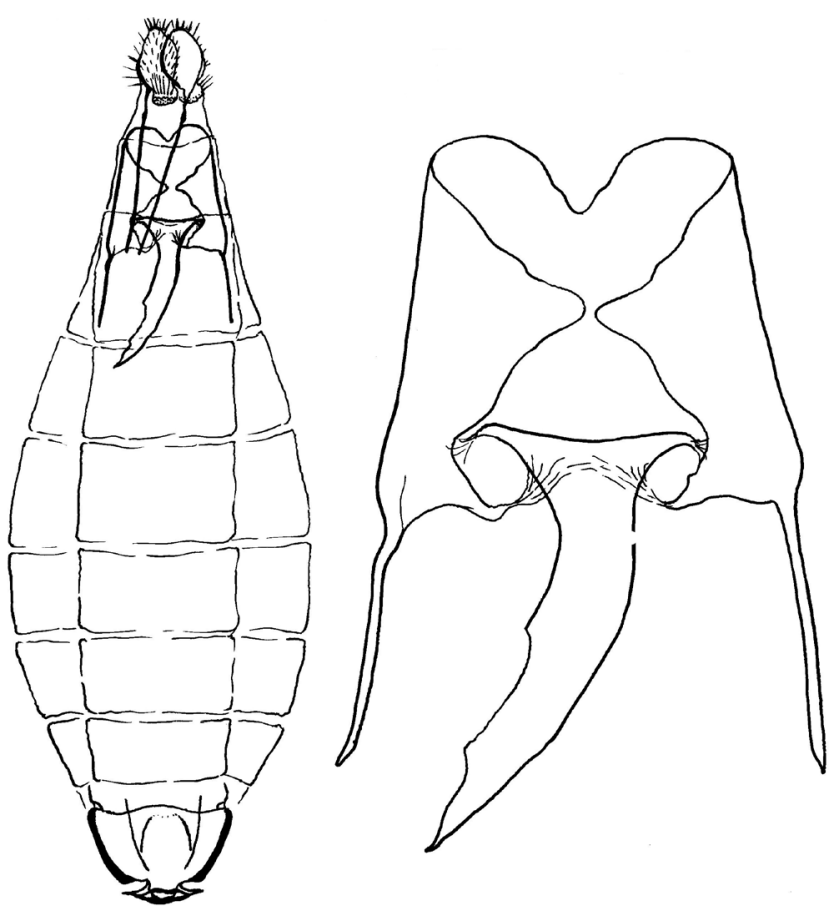

Fig. 9. Aproaerema semicostella (STAUDINGER, 1871): abdomen of the female (left), enlarged segment VIII, antrum and posterior part of ductus bursae (right) in ventral view, Capidava, 5.V.2018, genitalia prep. 2503, legit \& coll. S. \& Z. Kovács segment VIII; antrum funnel-shaped; posterior part of ductus bursae a slightly curved sclerotized tube, anterior part of ductus bursae and corpus bursae membranous, without signum.

Aproaerema anthyllidella (HÜBNER, 1813) is widely distributed in the Palaearctic region (ELSNER et al. 1999: 52). In Romania it was recorded from Dobrogea already by MANN (1866: 355), later from most of the country except Muntenia (RÁkosy \& Goia 2021: 60). Data from Satu Mare (Ardelean 1998: 168) are doubtful. CĂPUŞE (1964: 15) described A. aureliana CĂPUŞE, 1964 based on a unique male specimen from Mehadia, which currently is considered a junior synonym of $A$. anthyllidella (Huemer \& Karsholt 2020: 73). This appears to be the most common and widespread species of the genus and probably of the whole family in Romania.

Aproaerema sp. was mentioned by HuEMER et al. (2020, supplementary material 2, NJ tree 10; BOLD Systems) as Aproaerema sp.6 (BOLD:ACF7323) $\mathrm{n}=1$ : ROU, legit C. Wieser, coll. LMKK. Further data are not available. Probably it is an undescribed species.

Iwaruna GozMÁNY, 1957 is represented in Europe with four species, two of them, I. biguttella (DuPONCHEL, 1843) and I. klimeschi WolfF, 1958 share their BIN, but differ in morphology, and $I$. heringi Gozmány, 1957 requires taxonomic reassessment (HUEMER \& KARSHOLT 2020: 73, 121). In Romania only two species were recorded, but one of them it is in need of confirmation.

Iwaruna biguttella (DUPONCHEL, 1843) was recorded in Romania from Dobrogea (MANN 1866: 355, as G[elechia]. biguttella H. S.), Moldova (CARAdja 1899: 205), Crişana and Transylvania (PÁvel 1897: 107; RothSCHILD 1912a: 29; DiósZEGHY 1935: 124). These old data pre-date the recognition of Iwaruna klimeschi WoLfF, 1958 as a valid species. Later a specimen from Moldova (Câmpulung 27.VI, 1 万) was recorded apparently without the study of the genitalia (PeIU \& Nemeş 1970: 59), leaving its identity doubtful. The only recent mention is based on two specimens in the L. Diószeghy collection, identified, accordingly to their labels as I. biguttella by I. Căpuşe (Kovács \& KovÁcs 2001: 98). Both of them lack abdomens, so we were not able to check their genitalia, moreover all other specimens examined from the same site (Ineu, legit \& coll. L. Diószeghy) proved to be $I$. klimeschi. Iwaruna biguttella is recorded from some of the neighbouring countries (KARSHOLT 2004-2020, accessed 11 February 2020), consequently could be expected to occur also in Romania. For this reason we retain it in the list as a doubtful species, in need of confirmation, despite all the above mentioned uncertainties. 
Iwaruna klimeschi WoLfF, 1958 is distributed in the central parts of Europe (ELSNER et al. 1999: 52). In Romania it was mentioned only from Crișana (Ineu), the Transylvanian Basin (Viișoara, Toldal, Căpușu de Câmpie) and the Apuseni Mountains (Turda Gorge) by Kovács \& KovÁcs (2000: 39, 2001: 98), KovÁcs et al. (2002: 55). First record for Muntenia: Breaza (Buzău County), ca 350 m, 22-25.IV.2006, genitalia

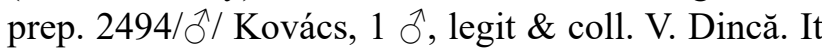
seems to be a rare, locally distributed species. It is probabe that all records of I. biguttella (see above) in fact refer to I. klimeschi.

Anacampsis CURTIS, 1827 is represented with 10 species in Europe, 5 of them recorded from Romania.

Anacampsis populella (CLERCK, 1759) is widely distributed in the Palaearctic region (ELSNER et al. 1999: 52). In Romania it was mentioned from Dobrogea already by MANN (1866: 353) and later recorded from most of the country except Muntenia (RÁkosy \& GoIA 2021: 60). As CARAdJA (1899: 205) did, so we found it common wherever the larval hostplants, different Populus species, are abundant.

Anacampsis blattariella (HÜBNER, 1796) is distributed in central and northern parts of the Palaearctic region(ELSNER etal.1999:52; JUNNILAINEN et al. 2010: 60). In Romania it was mentioned only from Transylvania (Retezat Mountains, Mestecănişul de la Reci, Harghita Mountains) (GozmáNy 1953: 184; Kovács \& KovÁCs 2001: 98) and Moldova (RÁKosY \& GoIA 2021: 60). Recently it was collected in the Southern Carpathians (Sibișel) (Albu \& Albu 2018: 20), in the above mentioned Transylvanian sites and in the Apuseni Mountains (Scăriţa-Belioara, legit \& coll. S. \& Z. Kovács). It is widespread across the Carpathians, but only locally frequent, where the larval host-plant, old Betula trees are abundant.

Anacampsis timidella (WocKe, 1887) is distributed from south-western Europe through central, southern and eastern Europe to Siberia, also Turkey and the Near East (JunNILAINEN et al. 2010: 61). In Romania it was mentioned only recently from Banat (KöNIG 1998), Dobrogea (WIESER et al. 2000: 69) and Transylvania (Kovícs \& Kovács 2000: $39)$. It is widespread and frequent in Dobrogea and Transylvania at warm low mountain habitats, forest edges, where the larval host-plants, the Quercus species are prevalent.

Anacampsis scintillella (FISCHER VON RöSLERSTAMM, 1841) is distributed in continental Europe except the northern parts, and western Kazakhstan (ELSNER et al. 1999: 53). In Romania it was mentioned from Dobrogea (MANN 1866: 353), Moldova (CARADJA 1899: 205), Banat (REBEL 1911: 412), Transylvania (CzeKelius 1918: 45) and Oltenia
(SzÉKeLY \& CERNEA 2007: 133). Recently it was collected from the Apuseni Mountains (Râmeț, legit $\&$ coll. V. Vicol). The record for Moldova was omitted by Rákosy \& GoIA (2021: 60).

Anacampsis obscurella ([DENIS \& SCHIFFERMÜLLER], 1775) is distributed in southern Europe and the Caucasus (ELSNER et al. 1999: 53). Barcoded European specimens cluster into three geographically separated BINs (HUEMER \& KARSHOLT 2020: 122). In Romania it was mentioned only from Transylvania (Sibiu) (CzeKelius 1918: 45). Recently it was collected in the Apuseni Mountains (Râmeţ, legit \& coll. V. Vicol). Material collected in Romania has not yet been genetically examined.

Mesophleps HüBNER, 1825 is a genus with 37 described (and two other formally not named) species, widely distributed in the Old World and only one species in the New World, it was recently revised by Li \& SATtLer (2012). In Europe five species are recognized, two other BINs from Spain and Greece probably represent undescribed species (HUEMER \& KARSHOLt 2020: 122). In Romania only two species are known.

Mesophleps silacella (HÜBNER, 1796) is distributed in Europe except the northernmost parts, North Africa and the Near East (BIDZILYA et al. 2019a: 8). In Romania it was mentioned from Dobrogea (Tulcea, Hagieni) by MANN (1866: 353) and POPESCU-GoRJ \& BRĂTĂŞEANU (1979: 266), and from Transylvania (Sibiu, Cloaşterf, Rimetea, Satu Mare, Geoagiu, Lempeș Hill) by Czekelius (1924: 256), RÁKOSY \& WieSER (2010: 54), ARDELEAN (1998: 168) and SzÉKELY \& CERNEA (2007: 133). Recently it was collected from the same regions, found in warm steppe habitats, often in large number mainly on limestone (legit \& coll. S. \& Z. Kovács).

Mesophleps trinotella (HERRICH-SCHÄFFER, 1856) is local in central Europe and widely distributed in southern Europe, Turkey, Israel, the Caucasus and Central Asia (Junnilainen et al. 2010: 61; BiDziLyA et al. 2019a: 8). In Romania it was recorded only from southern Dobrogea (Canaraua Fetii, Lespezi) (Kovícs \& Kovács 2000: 39, as Crossobela). Recently we collected it from different sites in Dobrogea (Vama Veche, Dobrogei Gorge, Măcin Mountains), in the Transylvanian Basin (Viişoara, 10.V.2018, 1 đ) and Banat (Dubova, 200-300 m, 17.VI.2021, 2 ภ, 1 †), legit \& coll. S. \& Z. Kovács). There are the first records for Transylvania and Banat.

Chelariini Le MARCHAND, 1947 include again the genus Anarsia (KARSHOLT et al. 2013: 342). In Europe 22 species, in Romania 9 are known.

Nothris HÜBNER, 1825 is a recently revised 
western Palaearctic genus with 8 recognized species (Karsholt \& Šumpich 2015: 417). In Europe 7, in Romania 2 species are known.

Nothris lemniscella (ZeLLER, 1839) is distributed in central and southern Europe, the Ural and Altai Mountains. Larvae feed on Globularia punctata Lapeyr. and Anthyllis vulneraria L. (KARSHOLT \& ŠUMPICH 2015: 481). In Romania it was found only in Transylvania from Băile Turzii (POPESCU-GoRJ 1964: 37) and Viişoara (Kovács et al. 2002: 55). A single specimen was collected later from the Baraolt Mountains (legit \& coll. S. \& Z. Kovács). It seems to be very rare in Romania.

Nothris verbascella ([DENIS \& SCHIFFERMÜLLER], 1775) is distributed in Europe except the northermost parts, Turkey and North Africa. Larvae feed on Verbascum species (KARSHOLT \& ŠUMPICH 2015: 486). In Romania it was recorded from Dobrogea already by MANN (1866: 355), later recorded from the whole country (RÁkosy \& GoIA 2021: 61). Analysing the recent collecting data (legit \& coll. S. \& Z. Kovács) it seems to be a common species, widely distributed across the country.

Neofaculta GoZmánY, 1955 is represented in Europe with 3 (HUEMER \& KARSHOLt 2020: 75), and only 2 species in Romania.

Neofaculta ericetella (GEYER, 1832) is a boreomontane species distributed in the northern part of Europe and the mountains of central and southern Europe (Elsner et al. 1999: 54). According to the latest molecular study the species shows high intraspecific DNA barcode variation and clusters into three BINs without geographical separation (Huemer \& Karsholt 2020: 122). In Romania it was mentioned only from Transylvania (Cibin Mountains) by Czekelius (1901: 87). Data from Ineu published by CĂPUŞE \& Kovács (1987: 59) were not confirmed by Kovács \& Kovács (2001), from the eight mentioned specimens six proved to be Helcystogramma triannulella (HERRICH-SCHÄFFER, 1854), one Platyedra subcinerea (HAwORTH, 1828) and another Bryotropha terrella ([DENIS \& SCHIFFERMÜLLER], 1775), consequently the symbol for Crişana must be deleted in RÁKosy \& GoIA (2021: 61). The presence of the species in Romania needs confirmation from voucher material.

Neofaculta infernella (HERRICH-SCHÄFFER, 1854) is another boreo-montane species distributed in the northern part of Europe and the mountains of central Europe (ElSNER et al. 1999: 54). In Romania it was mentioned only from the Southern (Cibin Mountains) (Czekelius 1905: 82) and Eastern Carpathians (Rodnei Mountains) (Szabó 1988). Recently it was collected again from the Southern (Făgăraş, Parâng
Mountains) and Eastern Carpathians (Şaru Dornei peat bog, Bicaz Gorge, Călimani, Harghita Mountains) between 1250-2100 m, often in large number (legit \& coll. S. \& Z. Kovács).

Hypatima HÜBNER, 1825 is represented in Europe with a single genetically variable species clustering into three BINs without geographical separation (Huemer \& Karsholt 2020: 75, 122). Material collected in Romania has not yet been genetically examined.

Hypatima rhomboidella (LiNNAEUS, 1758) is distributed in central and northern Europe and Siberia (ELSNER et al. 1999: 54). In Romania it was mentioned only from Transylvania (Braşov, Retezat Mountains, Vârghiş Gorge) (CzeKelius 1918: 44; DiószeghY 1930a: 284, as Chelaria hübnerella Don.; SzABóKY 1994: 349) and the Noroieni forest (ARDELEAN 1988: 168). Recently single specimens were collected in the Eastern Carpathians (Perşani, Baraolt, Harghita Mountains) and in Dobrogea (Măcin, flood area of the Danube, 26.VII.2000, 1 §, legit \& coll. S. \& Z. Kovács). It is the first record for Dobrogea.

Anarsia ZelLer, 1839 is considered to be a morphologically diverse genus, widely distributed in the Palaearctic region and accommodating about 100 species (GREGERSEN \& KARSHOLT 2017: 67-68). In Europe 11 (Huemer \& Karsholt 2020: 76), in Romania 4 species are known.

Anarsia lineatella ZELLER, 1839 is widely distributed in North Africa, central and southern Europe, through the Middle East and Turkey to Central Asia and China. It was introduced to North America and currently is widely distributed in the USA and southern Canada. Larvae feed on Rosaceae, especially Prunus species, and known as a serious pest of cultivated Prunus. Two other subspecies are recognized, A. lineatella heratella AMSEL, 1967 from Afghanistan and Iran, and A. lineatella tauricella Amsel, 1967 from Turkey (Gregersen \& KarsholT 2017: 78-80). In Romania the nominotypical subspecies was recorded from Dobrogea already by MANN (1866: 355), later mentioned from the whole country (RÁKosy \& GoIA 2021: 60). However, a reexamination of the voucher material is necessary, because some of the records may refer to the recently described A. innoxiella (see below). We examined material from Crișana (Ineu, legit \& coll. L. Diószeghy), and specimens attracted to light from the Transylvanian Basin (Glodeni, Toldal, Viișoara, legit \& coll. S. \& Z. Kovács) and Muntenia (Breaza, Buzău County, legit \& coll. V. Dincă, București, legit \& coll. V. Albu, legit \& coll. S. \& Z. Kovács).

Anarsia innoxiella GREGERSEN \& KARSHOLT, 2017 until very recently it was confused with $A$. 
lineatella. It was defined to be widely distributed and locally common in Europe, including Romania (paratypes from Banat: Dubova, Sasca Montană), larvae feed on Acer (GREGERSEN \& Karsholt 2017: 69-76). We examined material from the Eastern Carpathians (Harghita Mountains, Bicsad, 5.VII.1988, genitalia prep. 1100/ठ̂/ Kovács, 1 Љૈ; Baraolt Mountains, Ariușd, 600 m, 23.VI.2000, 1 q;

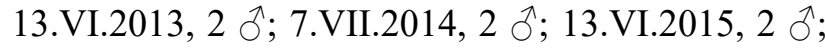
Trei Scaune Depression, Mestecănișul de la Reci, 540 m, 1.IX.2001, 1 đ), Transylvanian Basin (Lechința, 31.VIII.1996, 1 ठ;; 22.VI.2002, 1 §;; Glodeni, 16.VI.2007, 1 क; 21.VI.2012, 2 ठ; 18.VI.2016, 1 ठ), Apuseni Mountains (Turda Gorge, 16.VII.2015, 1 §), Dobrogea (Canaraua Fetii, 16-17.VIII.1991, genitalia prep. 1096/ठ/ Kovács, 1 đ; Măcin, Greci, 150-250 m, 10.VIII.2001, 5 ô, 2 क; 26.V.2007, 2 ภ, 2 क; 23.VII.2011, 1 §ै; 27.VI.2020, 1 q; Casimcei Plateau, Dobrogei Gorge, 13.VI.2001, 1 §; 28.V.2007, 1 స; 18.VI.2012, 1 đ; 20.VI.2016, 1 के; Hagieni forest, 22.VI.2012, genitalia prep. 2364/ $\hat{\delta} /$ Kovács, $2 \lambda$; Grindul Chituc, Periboina, 24.VIII.2017, 1 §;; Ostrov (Piatra), terasele Dunării, 28.VI.2020, 1 đ), Banat (Dubova), all legit \& coll. S. \& Z. Kovács, Crișana (Ineu, 22.VI.1932, 1 ð; 30.VI.1938, 1 ठ), legit \& coll. L. Diószeghy, and Muntenia (Breaza, Buzău County, ca 350 m, 24.VI.2006, 1 †), legit \& coll. V. Dincă. The recently collected material has been attracted to light. There are the first records for Crișana, Dobrogea, Muntenia and Transylvania.

Anarsia spartiella (SCHRANK, 1802) is widely distributred in Europe, extending eastwards to the Near East and Central Asia (JunNILAINEN et al. 2010: 62). In Romania it was recorded from Transylvania (Covasna, Cluj, Viişoara, Turda Gorge, Rimetea) (AbAfi-Aigner 1903: 192; Popescu-GorJ 1964: 37; KovÁCs et al. 2002: 55; RÁKosY 2002: 67; RÁKosY \& WIESER 2010: 54), Crişana (Ineu, Noroieni forest) (Kovács \& KovÁcs 2001: 99; Ardelean 1998: 168) and Moldova (RÁkosy \& GoIA 2021: 60). Recently collected from several sites in Transylvania (Eastern Carpathians, Transylvanian Basin, Apuseni Mountains), legit \& coll. S. \& Z. Kovács.

Anarsia eleagnella KUZNETSOV, 1957 is distributed from south-eastern Europe through Azerbaijan, Turkmenistan and Kazakhstan to Afghanistan and southern Siberia. Recently recorded also from central Europe (Hungary, Slovakia) (SzABÓKY et al. 2009: 143; PAstorális et al. 2018: 8). In Romania it was reported only once from Dobrogea (Eforie Sud, 8.VII.1947, genitalia prep. 4074/ $\lesssim /$ Karsholt, 1 , legit A. Popescu-Gorj, det. O. Karsholt) by POPESCUGORJ (1985a: 113), later mentioned only in checklists. Further, recent collections are from different sites in Dobrogea (Canaraua Fetii, Grindul Chituc, Măcin Mountains, Capidava, Ostrov (Piatra), legit \& coll. S. $\&$ Z. Kovács). Our collecting data reveal the presence of two generations, one in May and June and another from mid-July to mid-September. Its range seems to be in expansion, facilitated by the Eleagnus plantations.

Dichomeridinae HAMPSON, 1918 include again the genus Brachmia, which in the past has been treated as a different tribe (Brachmiini in Anacampsinae) (KARSHOLT et al. 2013: 343). In Europe 47 species, in Romania 21 are known and one unnamed species is also mentioned.

Dichomeris HÜBNER, 1818 is the largest genus within Gelechiidae, accommodating almost 600 species. In Europe 16 named and one more undescribed species are recognized (HuEMER \& KARSHOLT 2020: 76-78, 122). 10 species were recorded from Romania, but $D$. acuminatus (STAUDINGER, 1876) was deleted as improbable (see below in the list of the deleted species). An as yet unnamed species is also recorded.

Dichomeris juniperella (LinNAEUS, 1761) is distributed in Europe and North Africa (ELSNER et al. 1999: 55). The European material genetically clastered into two BINs, and may reflect cryptic diversity (HuEMER \& Karsholt 2020: 122). In Romania it was mentioned only from Transylvania (Cibin Mountains) by Czekelius (1901: 87) and Moldova (Suceava) by Popescu-GorJ \& Nemeş (1965: 158). Recently collected also from the Eastern Carpathians (Harghita, Ciuc Mountains) between 650-700 m, beaten from Juniperus communis L. during the day or attracted to light (legit \& coll. S. \& Z. Kovács). Material collected in Romania has not yet been genetically examined.

Dichomeris sp. is related to D. juniperella (LinNAEus, 1761). It is slightly smaller in size, with slender and dark grey coloured wings (Fig. 10), and an earlier flying period. The male genitalia (Fig. 11) with gnathos hook unevenly curved, lateral vincular process slightly pointed (instead of rounded), the ventromedian pair of vincular processes without the acute tip, phallus longer and slenderer, more acute, cornutus and coecum smaller than in D. juniperella. Material examined: Southern Carpathians, Făgăraş Mountains, Iezerul Caprei, 2000 m, 28.VII.1994, 1 गै; Parâng Mountains, Cărbunele, 2100 m, 13.VII.2016, genitalia prep. $2466 / \hat{\jmath} /$ Kovács, $1 \AA$, 5 q, legit \& coll. S. \& Z. Kovács. They were collected on south-facing slopes, beaten from Juniperus communis L. during the day in the Parâng and attracted to light in the Făgăraș Mountains. The material collected in Romania has not yet been genetically examined. Further studies are necessary to establish if it is conspecific with the specimens from the Alps mentioned by HuEMER \& KARSHOLT (2020: 122) or represent a different species.

Dichomeris marginella (FABRICIUS, 1781) is widely distributed in Europe, extending eastwards to Siberia, but rarely recorded in central Europe from 
scattered lowland localities (ELSNER et al. 1999: 55). In Romania the old records of Cleodora striatella $\mathrm{HB}$. from Dobrogea (MANN 1866: 355; CARADJA 1899: 206, 1901: 154) and Transylvania (CzeKelius 1900: 153) and of Paltodora striatella Нв. from Crișana (RoTHSCHILD 1913: 80) were incorrectly attributed to D. marginella by Rákosy \& GoIA (2021: 61), these combinations in fact refer to Isophrictis striatella ([DeNis \& SChIFFERMÜLleR], 1775). Because there is a recent Transylvanian record of $D$. marginella from Bădeni (MıHuŢ 1998: 74) only the symbols for Dobrogea and Crișana must be deleted in RÁkosy \& GoIA (2021: 61).

Dichomeris ustalella (FABRICIUS, 1794) is distributed in the central and northern parts of the Palaearctic region (ELSNER et al. 1999: 55). In Romania it was recorded from Banat already by Hedemann (1897: 30), later from most of the country except Crișana and Muntenia (RÁKOSY \& GoIA 2021:

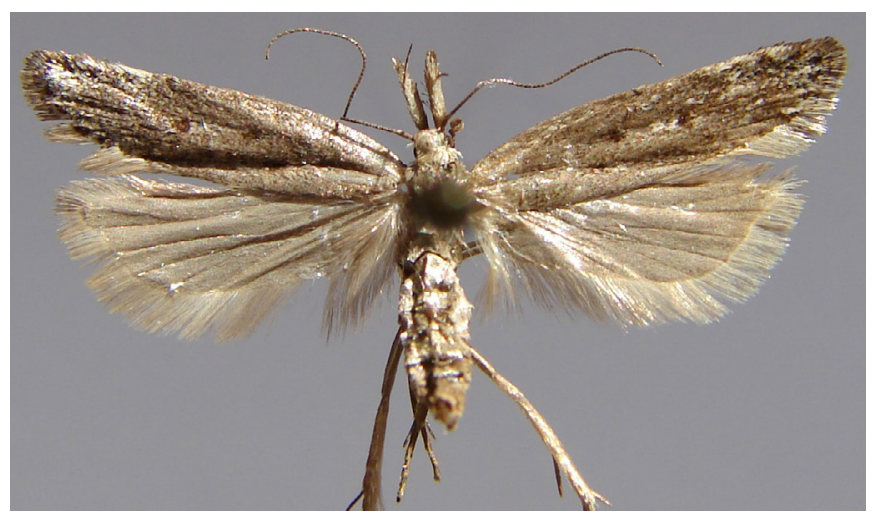

Fig. 10. Dichomeris sp.: adult, female, wingspan $17.5 \mathrm{~mm}$, Southern Carpathians, Parâng Mountains, Cărbunele, 2100 m, 13.VII.2016, legit \& coll. S. \& Z. Kovács.

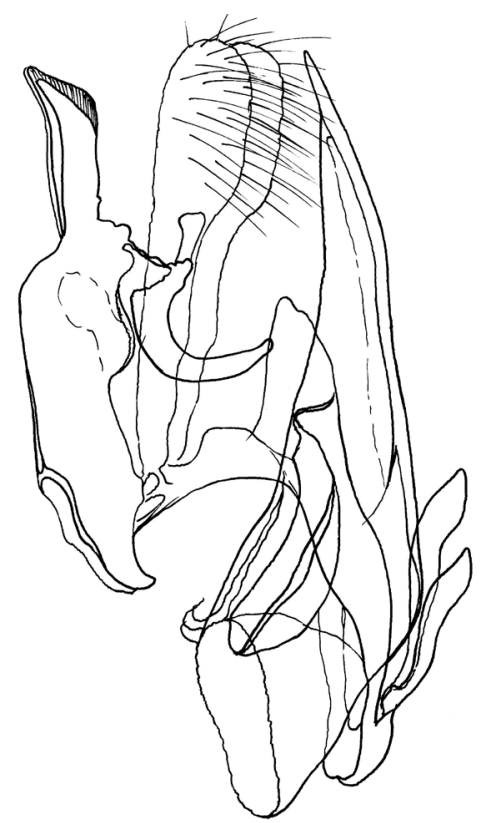

Fig. 11. Dichomeris sp.: free floating male genitalia in lateral view, genitalia prep. 2466, same data as Fig. 10.
61). We collected it from several Transylvanian sites and from Băile Herculane in Banat.

Dichomerisderasella ([DENIS\& SCHIFFERMÜLLER], 1775) is widespread across Europe (ElSNER et al. 1999: 55), the Caucasus, and throughout Siberia to the Russian Far East (JunNilainen et al. 2010: 63). In Romania it was mentioned from Dobrogea already by MANN (1866: 355), later from most of the country except Muntenia and Oltenia (RÁKosY \& GoIA 2021: 61). We examined recently collected material from Dobrogea, Banat and Transylvania (legit \& coll. S. \& Z. Kovács).

Dichomeris limosellus (SCHLÄGER, 1849) is distributed in the central and southern parts of the Palaearctic region from Western Europe to Mongolia and China (ELSNER et al. 1999: 55; JUNNILAINEN et al. 2010: 63). It was recorded from most of Romania except Banat and Oltenia (RÁKosy \& GoiA 2021: 61). One Romanian specimen has been sequenced (HUEMER et al. 2020, supplementary material 2, NJ tree 7). We examined recently collected material from Transylvania, Dobrogea (legit \& coll. S. \& Z. Kovács), Banat (Pecinișca, Caraș Severin County, 31.VII.1979, 1 ô, legit \& coll. V. Albu; Băile Herculane, 250 m, 16.VI.2021, 2 +, legit \& coll. S. \& Z. Kovács) and Muntenia (legit \& coll. V. Dincă). It is the first record for Banat.

Dichomeris rasilella (HERRICH-SCHÄFFER, 1854) is distributed throughout the central and southern parts of the Palaearctic region (ELSNER et al. 1999: 55). In Romania it was recorded from Transylvania already by CzeKelius (1905: 82), later mentioned from most of the country except Crișana (RÁkosy \& GoIA 2021: 61). It is the most frequent species of the genus in Dobrogea, far less prevalent in the central and northern regions of the country.

Dichomeris barbella ([DENIS \& SCHIFFERMÜLLER], 1775 ) is distributed in the southern parts of Europe, Turkey and the Caucasus (JunNiLAINEN et al. 2010: 63). In Romania it was recorded only from Transylvania (RothSCHILD 1912a: 29; CzeKELIUS 1918: 46; ViCOL 1997; ARDELEAN 1998: 168; KováCS \& KovÁCs 2000: 39; KovÁcs et al. 2002: 55), Crişana (CĂPUşe \& Kovács 1987: 62; ArdeleAN 1998; Kovícs \& KovÁcs 2001: 99) and one specimen from the Mad Volcanoes in Muntenia (Buzău County, Policiori, 12.VII.2015, legit C. Wieser, coll. LMKK) was sequenced (HuEMER et al. 2020, supplementary material 2, NJ tree 7; BOLD Systems, accessed 11 September 2021). We collected the species in the Transylvanian Basin and the Apuseni Mountains, adults are flying freely in the morning in steppe habitats, in two generations from the last days of March to the beginning of May and then again in July. Two old records cited by RÁKosy \& GoIA (2021: 221) 
do not refer to this species, because ReBEL (1911: 415) from Banat and CARADJA (1931: 343) from Muntenia both mentioned Topeutis barbella F., which is a junior synonym of Minetia crinitus (FABRICIUS, 1798) (Oecophoridae). Therefore the symbol for Banat must be deleted in Rákosy \& Goia (2021: 61).

Dichomeris alacella (ZeLLER, 1839) is recorded from most of Europe except the northernmost parts, extending eastwards to Israel, Iran and south-western Siberia (JunNILAINEN et al. 2010: 63; BidZILYA et al. 2019a: 26). In Romania it was recorded from Transylvania already by CzeKelius (1898: 74), later from the whole country (RÁKOSY \& GoIA 2021: 61). It is widespread and often frequent in warm low mountain habitats, especially in Dobrogea.

Dichomeris latipennella (REBEL, 1937) is recorded from central and eastern Europe except the southernmost parts, southern Siberia and the Russian Far East (JunNilainen et al. 2010: 63). Most recently reported also from Denmark (BuHL et al. 2020: 7). In Romania it was recorded only in Transylvania from the Bicaz Gorge (Kovícs \& Kovícs 1994: 48, as Acanthophila) and Călimani Mountains, legit \& coll. V. Vicol (RÁKosy \& Goia 2021: 61, 221). Recently only a few single specimens were atracted to light on some other Eastern Carpathian sites (Perşani, Ciucului and Harghita Mountains, legit \& coll. S. \& Z. Kovács). Probably the adults use to swarm high in the crown of their host-plant, Picea abies (L.) Karsten, where the larvae feed in the cones and this may be the reason why it is so rarely collected.

Anasphaltis MeYrick, 1925 is a genus with only one species with European distribution.

Anasphaltis renigerellus (ZELLER, 1839) is distributed in the central part of Europe from northern Italy to southern European Russia (ELSNER et al. 1999: 56). In Romania it was recorded only from Băile Herculane and Mehadia in Banat (HedemanN 1897: 30; Rebel 1911: 413; RothSCHILD 1912b: 28), Grumăzești in Moldova (CARADJA 1901: 154) and Turnu Roşu in the Southern Carpathians (Czekelius 1918: 46). Recently collected in the Eastern Carpathians (Harghita Mountains) and attracted to light in a forest near Băile Herculane in Banat (legit \& coll. S. \& Z. Kovács). It is a rare species in Romania.

Acompsia HüBNER, 1825 is a Palaearctic genus comprising 17 species distributed mainly in the mountains of Europe; it was revised by HuEMER \& Karsholt (2002). In Europe 14 species were recorded, in Romania 3, but $A$. minorella ReBel, 1899 has been deleted from the checklist (see below in the list of the deleted species).

Acompsia cinerella (CLERCK, 1759) is widely distributed in Europe, recorded from Turkey, Kazakhstan, southern Siberia and the Russian Far East (Huemer \& Karsholt 2002: 116). In Romania it was mentioned from Dobrogea already by MANN (1866: 353), later from the whole country (RÁкOSY \& GoIA 2021: 61). In Romania it is one of the most frequent and widespread species of the family, collected in extremely diverse habitats, e.g. steppe remnants of the hilly Transylvanian Basin, low mountains of Dobrogea, in mesophile mountain meadows exceeding $1300 \mathrm{~m}$ altitude, and peat bogs of the Eastern Carpathians.

Acompsia tripunctella ([DENIS \& SCHIFFERMÜLLER], 1775) is distributed in the Alps, Apennines, Carpathians and mountains of the Balkan Peninsula. Records from other parts of the Palaearctic region may refer to other externally similar species (HUEMER \& Karsholt 2002: 127). It is genetically variable, currently with seven known BINs, which may reflect cryptic diversity (HuEMER \& KARSHOLT 2020: 123). In Romania it was recorded from Moldova already by CARADJA (1899: 205) and HoRMUZAKI (1907: 84), from Transylvania by Czekelius (1918: 45) and DiószeGHY (1930a: 284), later from most of the country except Crişana and Dobrogea (RÁkosy \& GoIA 2021: 61). It is widespread, but not common in the Southern and Eastern Carpathians between 600$2000 \mathrm{~m}$. Material collected in Romania has not yet been genetically examined.

Brachmia HÜBNER, 1825 is represented in Europe with 4 species and probably an undescribed one from Greece (HuEMER \& KARSHOLt 2020: 123). In Romania also four have been recorded.

Brachmia dimidiella ([DENIS \& SCHIFFERMÜLLER], 1775 ) is widespread across Europe, recorded from the Caucasus, central Asia, southern Siberia and the Russian Far East (JunNILAINEN et al. 2010: 64). It is genetically variable, with three BINs in Europe, which may reflect cryptic diversity (HUEMER \& KARSHOLT 2020: 123). In Romania it was mentioned from Dobrogea already by MANN (1866: 355), later recorded from most of the country except Banat (RÁkosy \& GoIA 2021: 61). It is widespread in lowlands and warm low mountain habitats. Material collected in Romania has not yet been genetically examined.

Brachmia blandella (FABRICIUS, 1798) is widespread across Europe, recorded from Turkey, the Near East and the Caucasus (JunNilainen et al. 2010: 64). In Romania it was mentioned from Transylvania (Cetatea de Baltă) by Czekelius (1934: 68), Dobrogea (Hagieni) by POPESCU-GoRJ \& DrĂGHIA (1966: 186) and Crişana by Kovács \& KovÁcs (2001: 99). Recently it was collected in several sites in Transylvania and Dobrogea (legit \& coll. S. \& Z. Kovács). 
Brachmia procursella ReBEL, 1903 is very locally recorded from Austria, Hungary, Italy, Switzerland and the southern Ural Mountains in Russia (JUNNILAINEN et al. 2010: 64). In Romania it was mentioned from Suceava by NemEŞ (1968: 873), but not included in the earlier Romanian checklists (POPESCU-GorJ 1984: 129-130; KovÁcs \& Kovács 2000: 20) only later by RÁkosy et al. (2003: 70, 262) and RÁKosy \& GoIA $(2021:$ 61, 221). Its presence in Romania needs confirmation.

Brachmia inornatella (Douglas, 1850) is rare and local throughout central and northern Europe (ELSNER et al. 1999: 56). In Romania it was recorded only from Transylvania (Cisteiu de Mureş) by Czekelıus (1924: 256) and the Danube Delta (POPESCU-GorJ \& DrĂGHIA 1968: 236; POPESCU-GoRJ et al. 1972: 186). Recently single specimens were collected from the Transylvanian Basin (Toldal) and Dobrogea (Grindul Chituc, Murighiol), legit \& coll. S. \& Z. Kovács.

Helcystogramma ZELLER, 1877 is represented in Europe with 10 species, in Romania 6 have been recorded, but $H$. albinervis (GeRASIMOV, 1929) is deleted from the checklist (see below in the list of deleted species).

Helcystogramma lineolella (ZeLLER, 1839) is distributed from the Alps in France, through central, northern and eastern Europe, and throughout Siberia to the Sakhalin Island (JuNNILAINEN et al. 2010: 64). In Romania it is known only from very few specimens collected in the Danube Delta (Grindul Letea, C. A. Rosetti, 26-31.V.1980, 2 Oे, 1 \%; Caraorman forest, 20.VI.1983, 1 §) (POPESCU-GoRJ 1985b: 68, 1986: 81) and Grindul Chituc (Vadu, 2.VI.2014, 1 ô, legit \& coll. S. \& Z. Kovács), the latter attracted to light.

\section{Helcystogramma triannulella (HERRICH-} SCHÄFFER, 1854) is widespread across the southern and central parts of Europe and southern Asia (ELSNER et al. 1999: 56). In Romania it was recorded for the first time from Muntenia (Bucharest) by CARADJA (1899: 205), later from the whole country RákOSY \& GoIA (2021: 61). It is widespread and common in warm habitats in lowlands and low mountains. According to GoZMÁNY (1958: 154) the adults hibernate.

Helcystogramma lutatella (HERRICH-SCHÄFFER, 1854) is widely distributed in Europe, Israel, the Caucasus and southern Siberia (JUNNILAINEN et al. 2010: 64; BiDZILYA et al. 2019a: 27). In Romania it was recorded from Dobrogea (Măcin Mountains), the Transylvanian Basin (Viişoara) and the southern part of the Eastern Carpathians (Baraolt Mountains) by Kovícs \& Kovács (2000: 42) and one specimen was sequenced (HuEMER et al. 2020, supplementary material 2, NJ tree 15). Recent collections are from other Dobrogean (Dobrogei Gorge, Vama Veche and Dumbrăveni) and Transylvanian sites in the Transylvanian Basin (Glodeni, Toldal), Apuseni Mountains (Rimetea) and Eastern Carpathians (Trei Scaune and Ciuc Depression, Ciuc and Perşani Mountains), legit \& coll. S. \& Z. Kovács.

Helcystogramma rufescens (HAWORTH, 1828) is widely distributed throughout Europe and southwestern Siberia (JUNNILAINEN et al. 2010: 64). In Romania it was recorded from the Făgăraş Mountains (Czekelius 1918: 45), Ineu (Crişana) and the Retezat Mountains (Diószeghy 1935: 124; Kovécs \& Kovícs 2001: 100), the Bicaz Gorge (SzABóKy 1994: 349) and Noroieni and Mujdeni (ARDELEAN 1998: 168) (doubtful data). Recently single specimens were collected in the Eastern Carpathians (Bicaz Gorge, Mestecănişul de la Reci, Voşlăbeni, Perşani Mountains), the Apuseni Mountains (Pociovaliştei Gorge) and first record for Banat: Băile Herculane, 250 m, 16.VI.2021, 2 \%, Dubova, 200-300 m, 17.VI.2021, 1 ○े, legit \& coll. S. \& Z. Kovács.

Helcystogramma arulensis (REBEL, 1929) is recorded from central and eastern Europe and the Caucasus (JunNilainen et al. 2010: 65). It is one of the very few Gelechiidae species which are known to hibernate as an adult (HUEMER \& SATTLER 1995: 12). In Romania it was recorded from Crişana (Ineu) (Kovícs \& Kovács 2000: 42, 2001: 100) and Transylvania (VICOL 2006). Recently it was collected in Dobrogea (Vama Veche, 25.VII.2006, 9 §; Cetatea Histria, 27.VII.2006, 1 ), the Transylvanian Basin (Toldal, Glodeni) and the Eastern Carpathians (Bârsei Depression), legit \& coll. S. \& Z. Kovács. It is the first record for Dobrogea.

Apatetrinae Le Marchand, 1947 includes the tribes Pexicopiini and Apatetrini (KARSHOLT et al. 2013: 343). In Europe 31 species, in Romania only 7 are known and 1 unnamed is also mentioned.

Pexicopiini Hodges, 1986 comprises the genera Pexicopia Common, 1958, Platyedra Meyrick, 1895 and Sitotroga Heinemann, 1870, which currently are placed in the Apatetrinae (KARSHOLT et al. 2013: 343), earlier they have been treated as Pexicopiinae. In Europe are represented with 6 species, 3 of them recorded also from Romania.

Pexicopia Common, 1958 is represented in Europe and Romania with one species.

Pexicopia malvella (HÜBNER, 1805) is widely distributed in most of Europe except the northernmost parts, recorded from the Near East, the Caucasus, central Asia, North and Southeast Africa (ElsNer et al. 1999: 57). The species is genetically variable and in Europe clusters into two BINs without geographical separation (HUEMER \& KARSHOLT 2020: 123). In 
Romania it was recorded from most of the country except Banat (RÁKosy \& Goia 2021: 62). Recently collected material originates from Transylvanian and Dobrogean sites (legit \& coll. S. \& Z. Kovács). Material collected in Romania has not yet been genetically examined.

Platyedra Meyrick, 1895 is represented in Europe and Romania with one species.

Platyedra subcinerea (HAWORTH, 1828) is widely distributed in the Palaearctic region and North America (BIDZILYA et al. 2019a: 29). It is one of the very few Gelechiidae species which are known to hibernate as an adult (HUEMER \& SATTLER 1995: 12). In Romania it was recorded from Transylvania (Sibiu) already by Czekelius (1898: 73, as vilella Z.), later from most of the country except Muntenia (RÁkosY \& GoIA 2021: 62). We possess recently collected material from the Transylvanian Basin and single specimens from several Dobrogean sites (legit \& coll. S. \& Z. Kovács).

Sitotroga Heinemann, 1870 is represented with 2 species in Europe, in Romania only one.

Sitotroga cerealella (OLIVIER, 1789), the Angoumois Grain Moth is a cosmopolite, invasive species originating from North America (HUEMER \& RABITSCH 2002: 357) or Australasia (LopEZVAAMONDE et al. 2010: 608). Nowadays it is widespread across most of Europe except the northern parts (ELSNER et al. 1999: 57). In Romania it was recorded from Banat already by RoTHSCHILD (1912b: 179), later from most of the country except Muntenia (RÁkosy \& GoIA 2021: 62). It is common in the warm lowland areas of Romania, e.g. in the L. Diószeghy collection is one of the species with the largest number of individuals within Gelechiidae, with almost 90 specimens from Ineu (Crişana) (Kovács \& Kovács 2001: 100). We possess specimens got for identification from a granary from Ozun (Covasna County, 1977.XI.10). We also possess material from the same area (e.g. Sfântu Gheorghe, 1984.IX.29) collected in the nature. There are recently collected specimens also from the Transylvanian Basin, the lower regions of the Eastern Carpathians, from several Dobrogean sites and a few Muntenian localities (Bucureşti, 19.VII.1993, 1 q; 22.VIII.1995, 1 ઈ, legit \& coll. S. \& Z. Kovács; Breaza, Buzău County, ca. 350 m, 22.IX.2004, 1 ㅇ, legit \& coll. V. Dincă). It is the first record for Muntenia.

ApatetriniLeMarchand, 1947 isanunsatisfactory known tribe, the genera Dactylotula CocKerell, 1888 and Catatinagma Rebel, 1903 were studied by JunNilainen \& NupPonen (2010), Mondeguina CORley \& Rosete, 2020 was described recently (CORLEY et al. 2020) and Apatetris StAudinger,
1879 is still poorly defined, currently comprising species with unresolved relationships. Recently KARShOlt et al. (2013: 343) treated Pexicopiini and Apatetrini as sister groups, accommodating the genera Chrysoesthia and Metanarsia in the latter. In Europe currently seven genera and 24 species are recognized (Huemer \& Karsholt 2020: 80; Corley et al. 2020), in Romania only 5 species are known, one of them is as yet unnamed.

Dactylotula Cockerell, 1888 is represented in Europe by only two species. This genus is mentioned from Romania for the first time with 1 species.

Dactylotula kinkerella (SNellen, 1876) (Figs 12-13) is a local species known from scattered localities in Europe: sandy coast habitats in Germany, the Netherlands and southern Scandinavia (Sweden, Denmark), open localities in the French Alps,

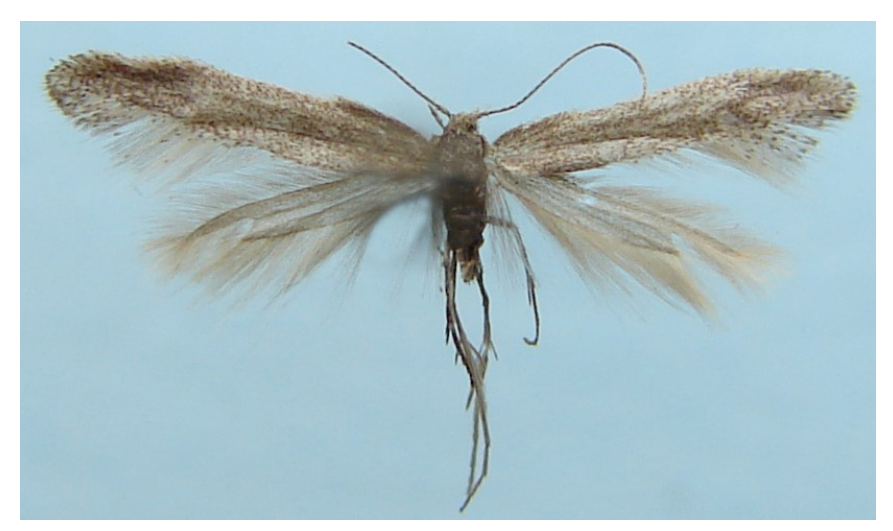

Fig. 12. Dactylotula kinkerella (SNELLEN, 1876): adult, male, wingspan 12 mm, Transylvanian Basin, Viişoara, 23.IV.1998, genitalia prep. 1392, legit \& coll. S. \& Z. Kovács.

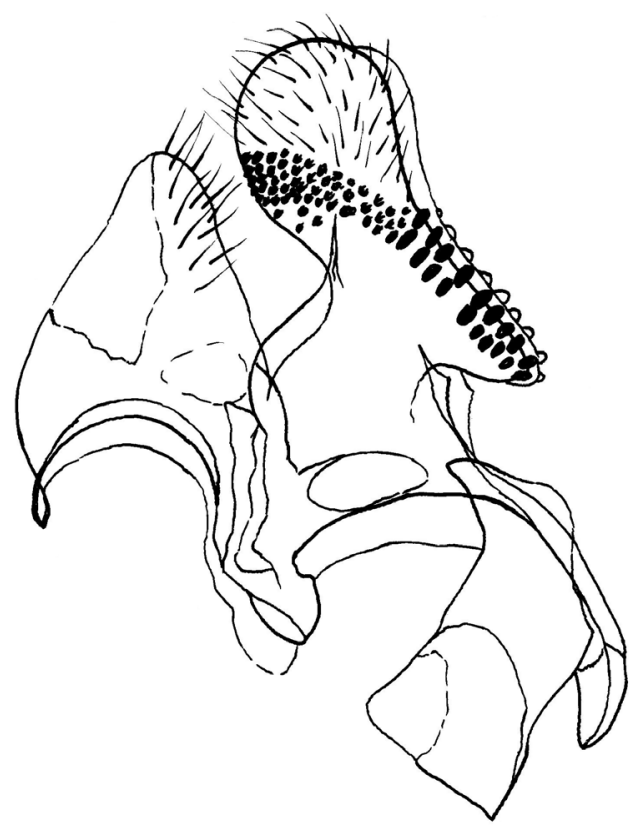

Fig. 13. Dactylotula kinkerella (SNelLen, 1876): free floating male genitalia in lateral view, genitalia prep. 1392, same data as Fig. 12. 
furthermore Latvia, Lithuania, Ukraine and Russia (the southern Ural Mountains) (ELSNER et al. 1999: 21; JunNilainen et al. 2010: 8; Wegner 2011: 4; AARVIK et al. 2017: 73). Genetically splits into two divergent clusters representing two BINs (HUEMER \& Karsholt 2020: 123), but according to CoRley et al. (2020: 164 and fig. 1) those from the Czech Republic, France and Spain in fact represent $D$. altithermella (Walsingham, 1903). First record for the Romanian fauna: Transylvanian Basin, Viişoara, 23.IV.1998, genitalia prep. 1392/ $/$ / Kovács, 2 औ, legit \& coll. S. $\&$ Z. Kovács. They were collected in a steppe habitat. Recently the sequencing of a specimen failed.

Apatetris StaUdinger, 1879 is worldwide in distribution, but comprises several unrevised and probably not closely related species which are only tentatively assigned to this genus.

Apatetris sp. (Figs 14-15) is probably an undescribed species and is only tentatively assigned to this genus. Material examined: Dobrogea, Hagieni forest, 22.VI.2016, genitalia prep. 2369/ふ//Kovács, 1 ठ; Dobrogea, Cotu Văii, 16.VIII.2019, 1 ơ; Oltenia, Schela Cladovei, 100 m, 22.IX.2019, TLMF Lep 28728, 2 ○, legit \& coll. S. \& Z. Kovács. The sequenced specimen clustered into the BIN BOLD:ABA4360 together with specimens from Bulgaria, North Macedonia, Croatia and Italy, these specimens are treated as Apatetris in the $\mathrm{NJ}$ tree, but as an unnamed group in the discussion by CORLEY et al. (2020: 154 fig. 1, 164). This BIN was incorrectly published as BOLD:AAV7596 by HUEMER et al. (2020, supplementary material 2, NJ tree 8; CORLEY et al. 2020: 153; BOLD Systems, accessed 10 February 2021). The Romanian specimens were attracted to light in steppe habitats.

Chrysoesthia HüBNER, 1825 is a genus with at least 25 described species, 17 of them are Palaearctic, 2 Nearctic, 2 Holarctic and 4 Afrotropical in distribution (BIDZILYA \& BUDASHKIN 2015: 217). It is represented with 11 species in Europe (HuEMER \& KARSHOLT 2020: 81), only 2 in Romania, both with Holarctic distribution and found predominantly in ruderal habitats.

Chrysoesthia drurella (FABRICIUS, 1775) is widely distributed in the Holarctic region (ELSNER et al. 1999: 23; JUNNILAINEN et al. 2010: 17), in Europe clusters into two geographically partly overlapping BINs (Huemer \& Karsholt 2020: 124). In Romania it was recorded already by MANN (1866: 355). Currently it is known from the whole country, most of the data are old, recent records there are only from the environs of Satu Mare (legit \& coll. I. Szabó) (Ardelean 1998: 169), the surroundings of Târgu Mureş (legit \& coll. V. Vicol), the Baraolt Mountains (Lempeș Hill) (Albu \& Albu 2018: 20) and Moldova (RÁkosy \& GoIA 2021: 54). Material collected in Romania has not yet been genetically examined.

Chrysoesthia sexguttella (THUNBERG, 1794) is widespread across the Holarctic region (ELSNER et al. 1999: 23). In Romania it was recorded from Dobrogea already by MANN (1866: 355). Mostly old data are known from the whole country (RÁkosy \& GoIA 2021: 54), we collected it only in Transylvania.

Metanarsia STAUDINGER, 1871 comprises 14 named species distributed in the Palaearctic region. Most of them are localized to the arid regions (deserts and semideserts) of central Asia, only a few are widely distributed. The genus was revised recently by BIDZILYA (2005a). In Europe four species are known, one of which also from Romania.

Metanarsia modesta STAUDINGER, 1871 is one of the most widespread species of the genus, inhabits

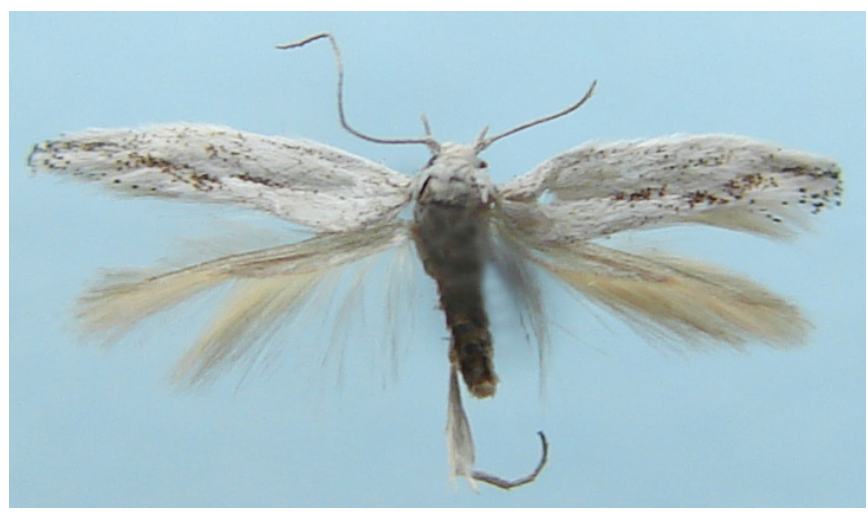

Fig. 14. Apatetris sp.: adult, male, wingspan $9.5 \mathrm{~mm}$, Oltenia, Schela Cladovei, 100 m, 22.IX.2019, legit \& coll. S. \& Z. Kovács

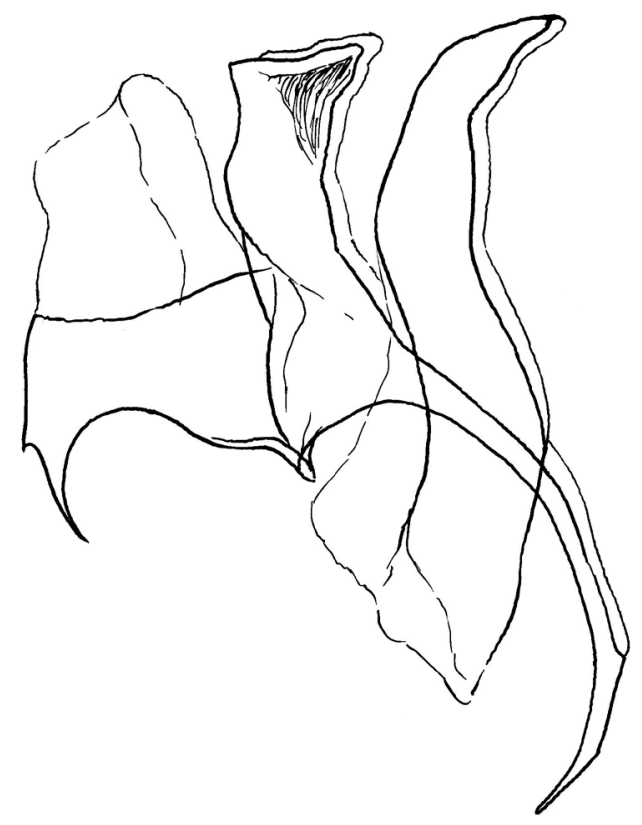

Fig. 15. Apatetris sp.: free floating male genitalia in lateral view, Dobrogea, Hagieni forest, 22.VI.2016, genitalia prep. 2369, legit \& coll. S. \& Z. Kovács. 
steppes and is distributed from central Asia through the Near East and south-eastern Europe to southern Italy (BIDZILYA 2005a: 282). Despite the species having been mentioned from Dobrogea (Eforie Sud, Hagieni) and the Danube Delta (Grindul Letea: Periprava) by several authors cited by RÁKosY \& GoIA (2021: 212), additionally recorded by CARADJA (1932: 11) and NEMEŞ \& DĂNILĂ (1970: 182), the species was neither included in the older Romanian checklists (POPESCU-GoRJ 1984; Kovács \& Kovács 2000) nor in the European one (KaRSHOlt \& RiedL 1996: 103). This error was corrected by RÁKOSY et al. (2003: 60, 250). CARADJA (1929b: 61, 1932: 11) stated that it was frequent at light. Only a single recently collected specimen is known, attracted to light in Dobrogea (Vama Veche, 25.VII.2006, 1 đ, legit \& coll. S. \& Z. Kovács).

Thiotrichinae Karsholt, Mutanen, Lee \& KaILA, 2013, a recently erected subfamily including only four genera, are worldwide in distribution and most diverse in Asia (KARSHOLT et al. 2013: 343). In Europe only two genera and five species are known. In Romania is represented by a single species.

Thiotricha MEYRICK, 1886 was originally described from New Zealand, later synonymized with Polyhymno Chambers, 1874, but recently reinstated to the generic status again. Being the largest and the best known genus, with nearly 100 species described, it is the type genus of the recently erected subfamily Thiotrichinae. The portable cases of the larvae constitute a particular life-history trait within Gelechiidae (KARSHOLt et al. 2013: 343-344). In Europe 4 species are known (HuEMER \& KarShOLt 2020: 82), from Romania 2 were recorded, but $T$. coleella (Constant, 1885) was excuded from the checklist (see below in the list of the deleted species).

Thiotricha subocellea (STEPHENS, 1834) is distributed in most of Europe except the northernmost and southernmost parts (ELSNER et al. 1999: 57). In Romania it was recorded for the first time from Crişana (Ineu) and Transylvania (Baraolt Mountains, Bicaz Gorge) (Kovács \& Kovács 1994: 45), later also from Satu Mare (ARDELEAN 1998: 168) (doubtful data). Recently it was collected in the Eastern Carpathians (Bicaz Gorge, Harghita Mountains) and Apuseni Mountains (Scăriţa-Belioara) (legit \& coll. S. \& Z. Kovács). We found cases with pupae of $T$. subocellea on stones and rocks.

Anomologinae MeYrick, 1926 are the sister group of Gelechiinae, it differ from the Anomologini of the earlier classifications, while the genera Chrysoesthia and Metanarsia are currently associated with Apatetrinae and Xystophora with Gelechiinae (Karsholt et al. 2013: 344; Huemer \& KarSHOlT 2020: 95). In Europe 258 species are known, in Romania 74, but one of them as yet unnamed.
Bryotropha HeInemanN, 1870 is a genus with Holarctic distribution, the global fauna was recently revised, recognizing 48 species, 38 of them in the western Palaearctic (RutTen \& KarSholt 2004; KARSHOLT \& RUtTEN 2005). In Europe 35 species are recorded (HUEMER \& KARSHOLT 2020: 83). In Romania 11 species are known, two others, $B$. plebejella (ZELLER, 1847) and B. umbrosella (ZELLER, 1839) have also been reported, but currently are deleted from the checklist (see below in the list of the deleted species).

Bryotropha domestica (HAWORTH, 1828) is one of the most widely distributed species of the genus, from the Canary Islands through North Africa, the Middle East and Europe to western Turkmenistan (Karsholt \& RUtTEn 2005: 99). In Romania it was recorded only from the Măcin Mountains in Dobrogea (KovÁCS \& KovÁCs 2000: 27; WIESER et al. 2000: 69). Later we collected it in further scattered localities in Dobrogea (Dobrogei Gorge, Cotu Văii, Dumbrăveni), all attracted to light in steppe habitats at low altitudes.

Bryotropha azovica BIDZILYA, 1996 was described from Ukraine (BIDZILYA 1996: 83; BidZILYA \& BUDASHKIN 1998: 7-8). The species was recorded from Romania only a few years later (Kovícs \& KovÁcs 2002b: 41-42). Since then a large series was collected at light in different sites of the northern half of the Romanian Black Sea coastal zone, where it seems to be a characteristic and frequent species of the salt marshes around the Sinoe-Razelm lagoon complex. Material examined: Dobrogea, Cetatea Histria, 25-26.VIII.1999, genitalia prep. 930/9/ Kovács, 1 ๆ; 11.VI.2001, 1 Ô, 1 o; 11.VIII.2001,

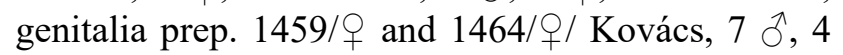

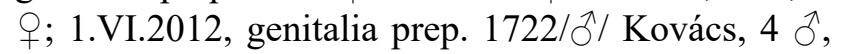
13 क; 17.VI.2012, genitalia slide Karsholt 5282 $\overbrace{}^{\lambda}$,

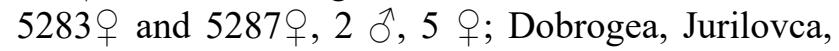
Capul Doloşman, 20.VIII.2009, 7 ภ, 4 ㅇ; Dobrogea, Grindul Chituc, Vadu, 17.VI.2012, genitalia prep. 1723/ठ/ Kovács, 7 Љ, 10 ᄋ; 2.VI.2014, genitalia

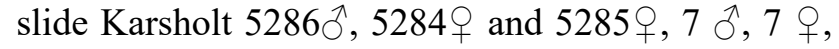
21.VI.2016, TLMF Lep 27427, 1 क, legit S. \& Z. Kovács; Dobrogea, Grindul Chituc, Periboina, 8-9. VIII.2011, 1 क; 29-30.VIII.2012, 1 q, legit R. Kis \& I. Kovács; 14.VIII.2014, 1 §ో; 15.VIII.2014, genitalia slide Karsholt 5282 ${ }^{\lambda}, 6$ ๙, 1 \%; 24.VIII.2017, TLMF Lep 27428, 1 §, 14 q; 15.VIII.2019, 2 q, legit S. \& Z. Kovács, coll. ZMUC, coll. TLMF, coll. S. \& Z. Kovács. The comparison of this material with the original description of the species (BIDZILYA 1996; BIDZILYA \& BUDASHKIN 1998: 7-8) revealed that confirmed records are known today only from Ukraine and Romania. Two recently sequenced Romanian specimens clustered into a separate BIN and confirm this separate status (P. HUEMER pers. comm.). All other records of B. azovica sensu KARSHOLT \& RUTTEN, 2005 from Turkey, Cyprus, Greece, Bulgaria and 
North Macedonia (KARSHOLT \& RUtTen 2005: 104; LEPIFORUM, accessed 12 April 2020; BOLD Systems, accessed 10 December 2020; HUEMER et al. 2020: supplementary material 2 , NJ tree16) are based on misidentifications and in fact represent a different, as yet unnamed species. To correct this error a separate paper is in preparation by O. Karsholt, O. Bidzilya, P. Huemer, Z. Kovács \& S. Kovács.

Bryotropha patockai ELSNER \& KARSHOLT, 2003 (Figs 16-17) was described from specimens collected in Slovakia, Czech Republic, Hungary and Croatia (ELSNER \& KARSHOLT 2003: 72), since then recorded also from Ukraine (KARSHOLT \& RUTTEN 2005: 107). First record for the Romanian fauna: Eastern Carpathians, Perşani Mountains, Vârghiş Gorge, 600-900 m, 26.VI.2016, genitalia prep. 2387/O/

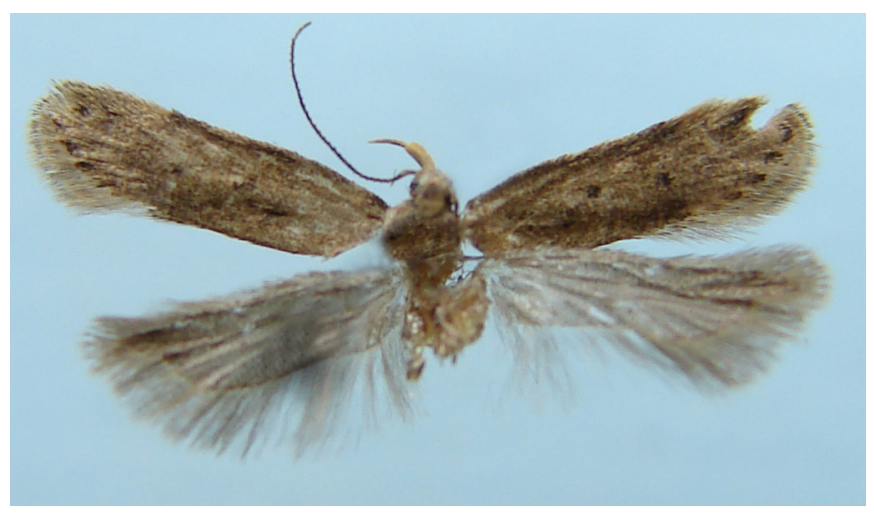

Fig. 16. Bryotropha patockai ElSNER \& KARSHOLT, 2003: adult, female, wingspan $13 \mathrm{~mm}$, Eastern Carpathians, Perşani Mountains, Vârghiş Gorge, 600-900 m, 26.VI.2016, genitalia prep. 2387 , legit \& coll. S. \& Z. Kovács

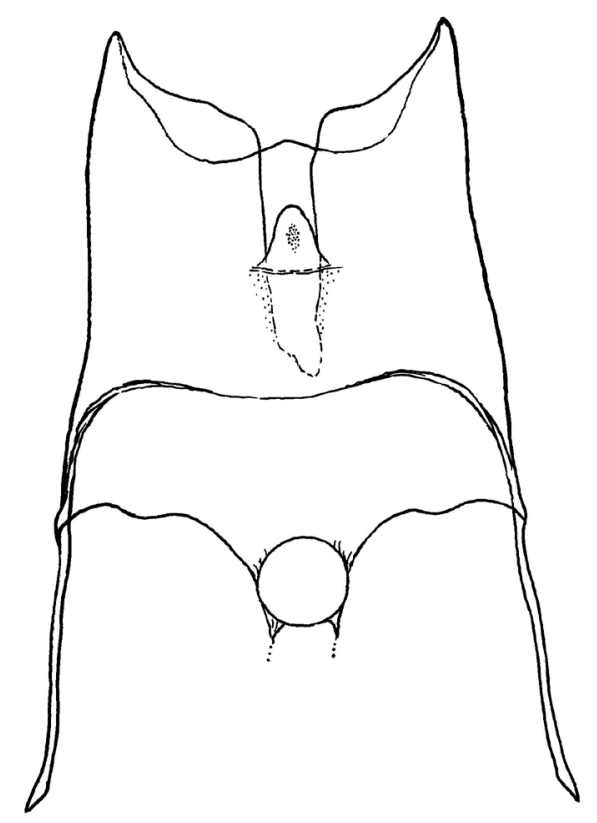

Fig. 17. Bryotropha patockai ElSNER \& KARSHOLT, 2003: segment VIII and posterior part of ductus bursae of the female genitalia in ventral view, genitalia prep. 2387 , same data as Fig. 16.
Kovács, 1 q, legit \& coll. S. \& Z. Kovács. The moth was collected during the day.

Bryotropha tachyptilella (REBEL, 1916) is a local species, distributed from central Europe through south-eastern Europe to south-western Asia (KARSHOLT \& RUTTEN 2005: 109). In Romania it was recorded only from the Măcin Mountains and Canaraua Fetii in Dobrogea (Kovács \& Kovács 2000: 25; WieSER et al. 2000: 68; KARSHOLT \& RUTTEN 2005: 109). One specimen from Romania was sequenced (HUEMER et al. 2020, supplementary material 2, NJ tree 16). Later we collected it in further scattered localities from Dobrogea (Dobrogei Gorge, Hagieni, Şipote, Dumbrăveni, Ostrov), during the day by netting in ruderal herb communities, or attracted to light in steppe habitats, all at low altitudes. The collecting data indicate the presence of two generations, adults are on the wing in May and June and again from the beginning of August to mid September.

Bryotropha terrella ([DENIS \& SCHIFFERMÜLLER], 1775 ) is one of the most common and widely distributed Gelechiidae species in Europe, recorded also from south-eastern Asia and the Russian Far East (KARSHOLT \& RUTTEN 2005: 114). In Romania it was mentioned from Dobrogea already by MANN (1866: $353)$. It is a common species recorded from most of the country except Oltenia (RÁKosY \& GoIA 2021: 55). Data from Satu Mare and Turulung (ARDELEAN 1998: 169) are doubtful. It can be found from lowlands up to about $2000 \mathrm{~m}$ in the mountains (POPESCU-GoRJ 1995: 176), but it is most prevalent in the mountains between 500 and $1000 \mathrm{~m}$.

Bryotropha desertella (Douglas, 1850) is common and widely distributed in Europe, recorded also from North Africa, Turkey, central Asia and the Russian Far East (Karsholt \& RutTen 2005: 116). It is a genetically variable species clustering into three BINs in Europe without geographical structure (HuEMER \& Karsholt 2020: 124). In Romania it was mentioned from Transylvania (Sibiu) already by Czekelius (1898: 73), later from most of the country except Banat (RÁKOSY \& GoIA 2021: 55). We collected it from the sea level (in Dobrogea) up to $800 \mathrm{~m}$ (in the Ciuc Mountains), but it is most prelevant in various habitats across the Black Sea coastal zone and other warm sites in Dobrogea. First record for Banat: Băile Herculane, 28.VI.1998, 1 +, legit V. Albu, coll. S. \& Z. Kovács. Material collected in Romania has not yet been genetically examined.

Bryotropha plantariella (TENGSTRÖM, 1848) (Figs 18-19), with Holarctic distribution, it was confirmed only from the northern parts of Europe (KARSHOLT \& RUtTEN 2005: 121). In Romania it was mentioned from Transylvania (Retezat 
Mountains) (GozmánY 1953: 183) and the Bucegi Mountains (PopesCu-GoRJ 1995: 176). Kovícs \& Kovács (2000: 25) considered the species requiring confirmation and the Romanian records were treated as doubtful by KARSHOLT \& RUTTEN (2005: 121). Now we confirm its presence from voucher material: Eastern Carpathians, Giurgeu Depression, Voşlăbeni, Szenéte, 760 m, 10-13.VII.2002, 14 ô, 1 +; 28.VI.2003, 4 के; 25.VII.2004, genitalia prep. 1721/ð/ Kovács, 4 ठં; 20.VII.2007, 6 ठ; 10.VII.2017, 1 गे; Ciuc Depression, Vrabia, 650 m, 8.VII.2006, genitalia prep. 1744/ふ/ Kovács, 7 ઊં; Giurgeu Depression, Borzont, 800 m, 20.VIII.2013, 1 万, legit \& coll. S. \& Z. Kovács. The moths were attracted to light in flatmoors. O. KARSHOLT (pers. comm.) confirmed their identification.

\section{Bryotropha galbanella (ZELLER, 1839) is}

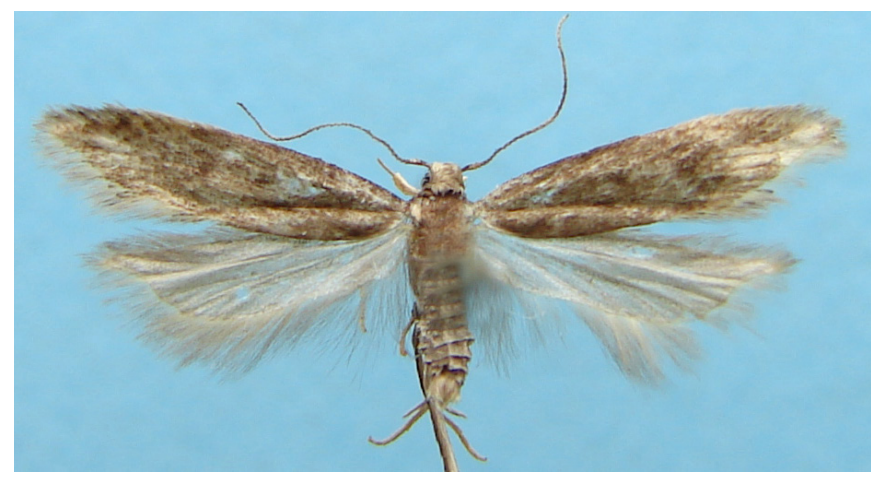

Fig. 18. Bryotropha plantariella (TENGSTRÖM, 1848): adult, male, wingspan $14.5 \mathrm{~mm}$, Eastern Carpathians, Giurgeu Depression, Voşlăbeni, Szenéte, 760 m, 28.VI.2003, legit \& coll. S. \& Z. Kovács

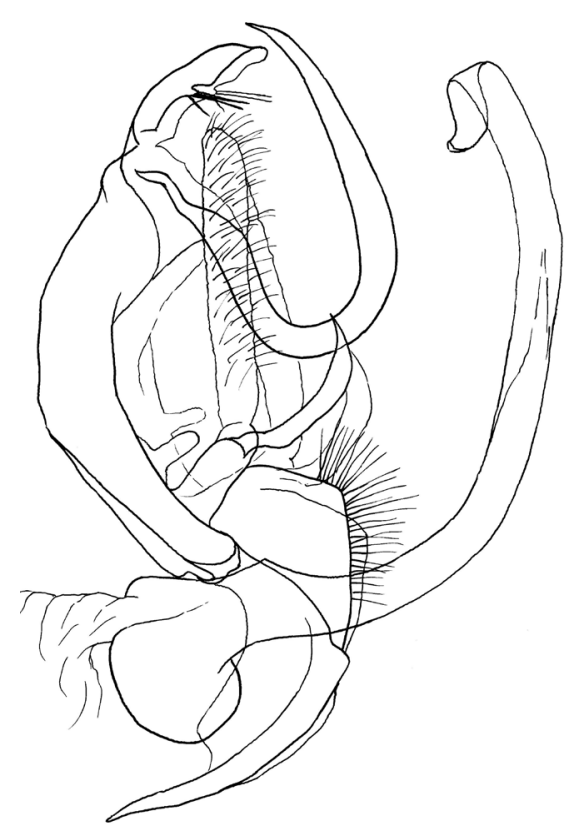

Fig. 19. Bryotropha plantariella (TENGSTRÖM, 1848): free floating male genitalia in lateral view, Eastern Carpathians, Giurgeu Depression, Voşlăbeni, Szenéte, 760 m, 25.VII.2004, genitalia prep. 1721 , legit \& coll. S. \& Z. Kovács. distributed in the Holarctic region (KARSHOLT \& RUTTEN 2005: 122). In Romania it is a characteristic species of the Picea, and in the peat bogs of Pinus forests, in which the mossy undergrows are most abundant, between $650-1800 \mathrm{~m}$ in the Eastern (HormuZaKi 1907: 83; Nemeş \& DĂNILĂ 1970: 185; RÁkosy et al. 1998: 21; legit \& coll. S. \& Z. Kovács) and Southern Carpathians (CzeKelius 1901: 87; Diószeghy 1930a: 285; KovÁcs \& Kovícs 2001: 92). A record from the Lempes Hill (Baraolt Mountains) by Albu \& Albu (2018: 20) was based on misidentified $B$. desertella specimens. In July and the beginning of August adults fly freely in the early morning at sunrise, much rarer can be found during the day or attracted to light.

Bryotropha affinis (HAWORTH, 1828) is a European species (KARSHOLT \& RUTTEN 2005: 139). In Romania there are old records from Moldova (CARADJA 1899: 204), the Retezat Mountains (Diószeghy 1935: 124; Kovács \& Kovács 2001: 92) and Crişana (Kovícs \& KovÁcs 2001: 92). Data from Satu Mare and Turulung (ARDELEAN 1998: 169) are doubtful. First record for Dobrogea: Grindul Chituc, Vadu, 28.VIII.1999, genitalia prep. 1178/ठ/ Kovács,

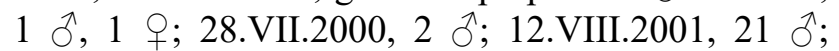
30.VIII.2003, 12 Oे, 1 क; 15.IX.2006, 1 ठ; 17.VI.1012,

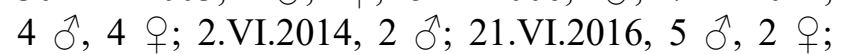
Dobrogei Gorge, 29.VII.2000, 1 q; Cetatea Histria, 11. VIII.2001, 4 रें 27.VII.2006, 1 के; 17.VI.1012, 1 ○; Grindul Chituc, Periboina, 15.VIII.2014, 1 ठ, 1 क; 24.VIII.2017, genitalia prep. 1978/ふ// Kovács, 3 $\hat{~}, 1$ o; 15.VIII.2019, 2 ô, legit \& coll. S. \& Z. Kovács. We collected it also in the Eastern Carpathians (Sfântu Gheorghe).

Bryotropha similis (STAINTON, 1854) is Holarctic in distribution (KARSHOLT \& RUTTEN 2005: 142). In Romania it was recorded for the first time based on a unique specimen from the Retezat Mountains (1100 m, 12.VII.1929, genitalia prep. 1221/ð/ Kovács, 1 $\widehat{\jmath}$, legit \& coll. L. Diószeghy) by Kovács \& Kovács (2000: 27; 2001: 92). The records from low altitudes of the Eastern Carpathians (Lempes Hill in Baraolt Mountains, Bogata forest in Perșani Mountains) by AlBu \& Albu (2018: 20) in fact refer to Aproaerema sangiella (Stainton, 1863) (see above) and Bryotropha terrella specimens. Recently only two additional specimens were collected in the Southern Carpathians: Făgăraş Mountains, Iezerul Caprei, 2000 m, 9.VIII.2013, 1 đ̃; Bucegi Mountains, 1900 m, Jepii valley, 7.VII.2015, 1 §, legit \& coll. S. \& Z. Kovács. In Romania it seems to be a rare species, restricted to the high mountains. It is the first record for Muntenia.

Bryotropha senectella (ZELLER, 1839) is widespread throughout Europe (KARSHOLT \& RUTTEN 2005: 145). In Romania it was recorded only from Banat (RothSCHILD 1912c: 179), Transylvania 
(Czekelius 1918: 44, 1924: 256), Crişana (Kovács \& Kovács 2001: 92) and Moldova (RÁKosY \& GoIA 2021: 55). Recently it was collected from the Eastern Carpathians (Bicaz Gorge, Călimani, Harghita, Baraolt, Perșani and Ciuc Mountains, Giurgeului, Trei Scaune and Bârsei Depressions), Apuseni Mountains (Trascău and Gilău Mountains) and the Transylvanian Basin (Viişoara) (legit \& coll. S. \& Z. Kovács). First record for Dobrogea: Măcin Mountains, Greci, 150 200 m, 10.VIII.2001, genitalia prep. 1745/q/ Kovács, 1 O; Hagieni forest, 26.VII.2006, genitalia prep. 2415/ふ/ Kovács, 1 đ๋; 22.VI.2016, 1 q; Dumbrăveni, 26.VIII.2017, genitalia prep. 2414/ㅇ/ Kovács, 1 ㅇ, legit \& coll. S. \& Z. Kovács. We collected the species mainly attracted to light, only a few specimens during the day.

Aristotelia HüBNER, 1825 is a genus which is still waiting for a revision and, according to HUEMER \& KARSHOLT (2020: 125), includes several undescribed species. Comprises almost 150 species worldwide, about 30 from the Palaearctic region (BIDZILYA 2015: 223). Currently 19 species are recorded from Europe, 5 of them also from Romania. One of the supposedly undescribed species is known from Romania as well.

Aristotelia decurtella (HüBNER, 1813) is distributed in Europe and south-western Asia (ELSNER et al. 1999: 22), genetically clusters into two BINs (Huemer \& Karsholt 2020: 125). In Romania it was mentioned only very recently as Aristotelia decurtella B (BOLD:ABA3199), based on a specimen from Dobrogea, Babadag, KLM Lep 06006, legit C. Wieser, coll. LMKK (HUEMER et al. 2020, supplementary material 2, NJ tree 11; BOLD Systems, accessed 7 December 2020). We examined the following material: Dobrogea, Hagieni forest, 17.IX.2004, 1 §ं; 22.VI.2016, 3 ऊ; Casimcei Plateau, Dobrogei Gorge, 19.VIII.2009, genitalia prep. 2231/q/Kovács, 1 ○, 1 q, legit \& coll. S. \& Z. Kovács. All of the specimens were collected at light in steppe habitats on limestone.

Aristotelia decoratella (STAUDINGER, 1879) (Figs 20-21) is distributed throughout southern Europe (ELSNER et al. 1999: 22). First record for the Romanian fauna: Oltenia, Schela Cladovei, 100 m, 22.IX.2019, genitalia prep. 2416/ $/$ / Kovács, 1 \%, legit \& coll. S. $\&$ Z. Kovács. It was attracted to light in a xerothermic meadow.

Aristotelia subdecurtella (StAINTON, 1859) is distributed in Europe and the Russian Far East (ELSNER et al. 1999: 22; JUNNILAINEN et al. 2010: 17). The species genetically clusters into two BINs with overlapping distribution in Europe (HuEMER \& KARSHOLT 2020: 125). It was mentioned from the Danube Delta (Popescu-GorJ \& DrĂGHIA 1968: 235) and Transylvania (RÁKosy \& GoIA 2021: 53).
Collected by us in sandy (Mestecănişul de la Reci) or steppe habitats at low altitudes in the Transylvanian Basin (Glodeni, Toldal).

Aristotelia sp. (Figs 22-23) was mentioned from Romania as Aristotelia sp.5 (BOLD:ADC8189) by HUEMER et al. (2020, supplementary material 2, NJ tree 11) based on a single specimen deposited in the collection of C. Wieser. It is probably an undescribed species genetically related to $A$. subericinella (DuPONCHel, 1843). Material examined: Dobrogea, Lespezi, 18.V.1994, genitalia prep. 1009/ $/$ / Kovács, 1 đ̊; Măcin Mountains, Pricopan Peak, 150 m, 27 28.VI.1997, 1 ठึ; 23-29.VIII.2003, 2 o+; Casimcei Plateau, Dobrogei Gorge, 27.VIII.1999, 2 ภ, 1 우

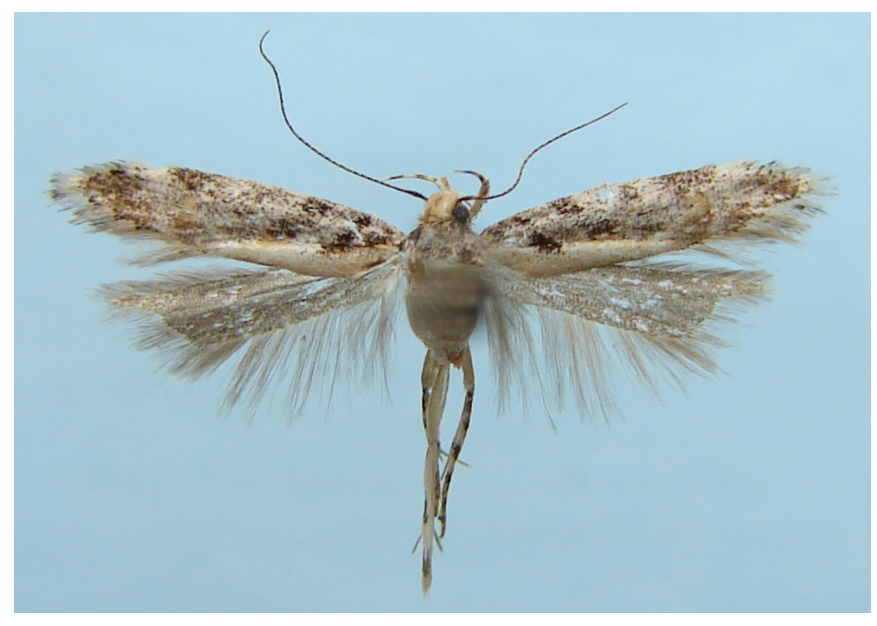

Fig. 20. Aristotelia decoratella (STAUDINGER, 1879): adult, female, wingspan $15 \mathrm{~mm}$, Oltenia, Schela Cladovei, 100 m, 22.IX.2019, genitalia prep. 2416, legit \& coll. S. \& Z. Kovács

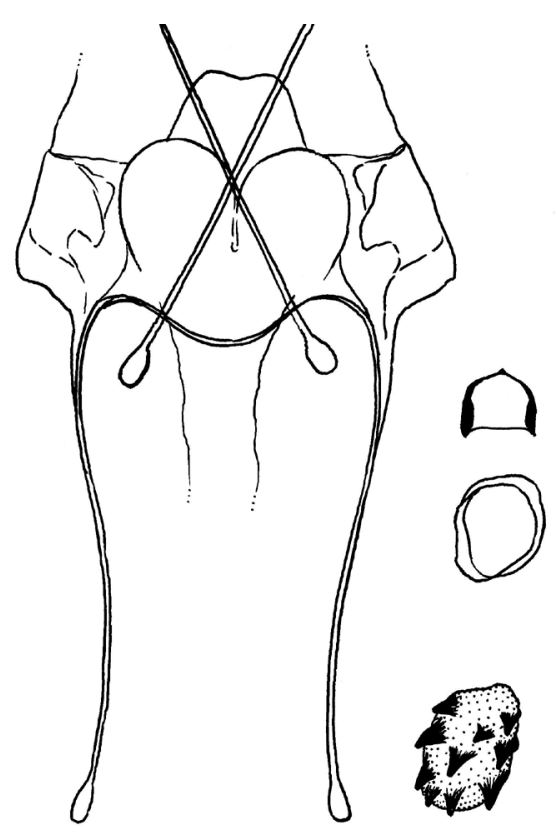

Fig. 21. Aristotelia decoratella (STAUDINGER, 1879): segment VIII, posterior part and sclerits of ductus bursae, and signum of the female genitalia in ventral view, genitalia prep. 2416, same data as Fig. 20. 
29.VII.2000, genitalia prep. 2235/ð/ Kovács, 3 ภै; 19.VIII.2009, 3 ơ; 16.VII.2010, 1 क; 26.IX.2010, genitalia prep. 2242/o/ Kovács, 2 O , 1 क; 1.VI.2014, 1 §ं; Vama Veche, 25.VII.2006, 1 q; 15.IX.2006, 1

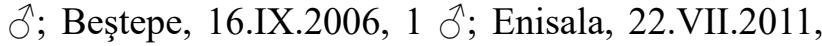
genitalia prep. 2239/ठ/ Kovács, 1 đं; Crucea, 31.VIII.2012, 1 ठૈ; Rasova 4.VII.2015, genitalia prep. 2236/ठో/ Kovács, 1 ठ; Dumbrăveni, Canara, 26.VIII.2017, TLMF Lep 27434, TLMF Lep 27435, 3 Ô, 1 q; Cotu Văii, 16.VIII.2019, 1 đે; Ostrov (Piatra), 13.IX.2019, $1 \hat{\sigma}, 3$ q; Ostrov (Piatra), Terasele Dunării, 28.VI.2020, 4 ô, 3 ㅇ, legit \& coll. S. \& Z. Kovács, coll. TLMF, coll. ZMUC; Măcin Mountains, Pricopan Peak, 150 m, 19-24.IX.2004, genitalia prep. 2237/O/ Kovács, 1 q; Cerna, 10.V.2007, genitalia prep. 2238/ð/ Kovács, 1 đૈ, legit I. Kovács, coll. S. \& Z. Kovács. The specimens were collected only in Dobrogea, during the day or attracted to light in

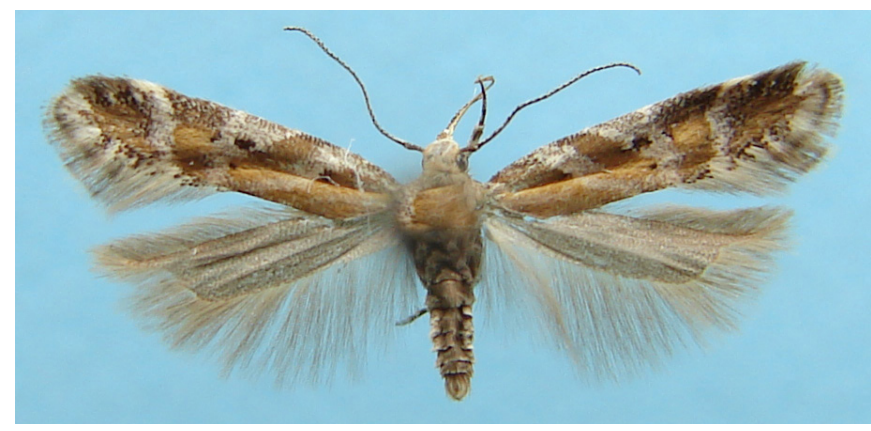

Fig. 22. Aristotelia sp.: adult, male, wingspan $12.5 \mathrm{~mm}$, Casimcei Plateau, Dobrogei Gorge, 29.VII.2000, legit \& coll. S. \& Z. Kovács.
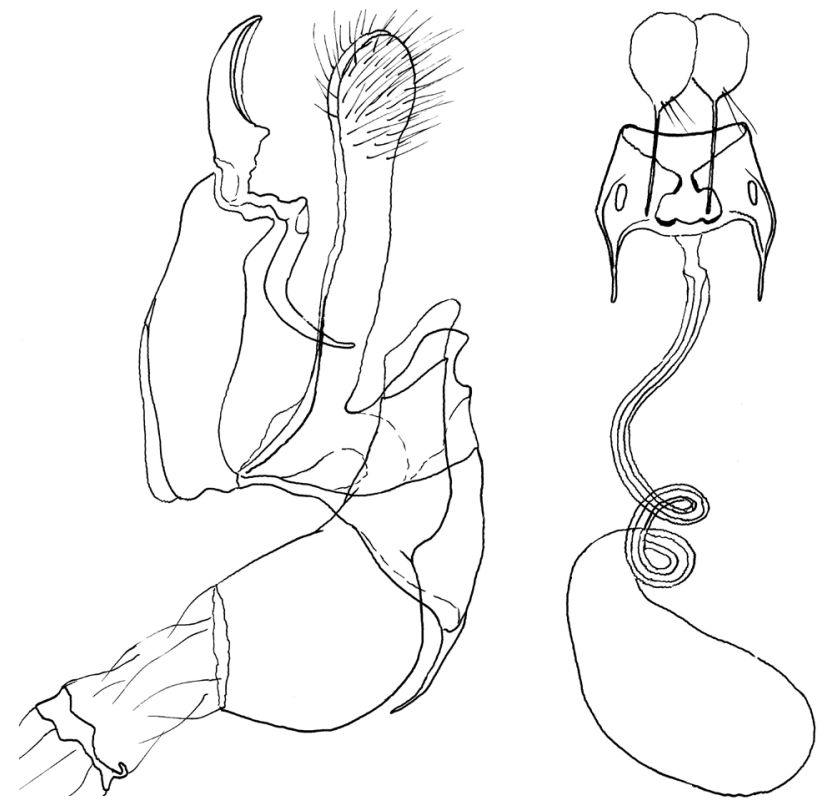

Fig. 23. Aristotelia sp.: free floating male genitalia in lateral view, Dobrogea, Enisala, 22.VII.2011, genitalia prep. 2239, legit \& coll. S. \& Z. Kovács (left); female genitalia in ventral view, Dobrogea, Măcin Mountains, Pricopan Peak, 150 m, 19-24.IX.2004, genitalia prep. 2237, legit I. Kovács, coll. S. \& Z. Kovács (right). steppe habitats. From external characters alone the adult is difficult to distinguish from the closely related A. subericinella, but it has a thinner longitudinal yellow strip in the middle of the postmedian area. The male genitalia differ in subtle details: more bent gnathos hook; slightly slenderer valva exceeding uncus, cucullus lacks the inwardly oriented ventral fold; slenderer sacculus of slightly variable length, with the highest point on its ventral part; smaller vinculum and saccus; slenderer and less curved phallus. The female genitalia are strikingly different being fully membranous; antrum with weaker sclerits; membranous ductus bursae not spiralled and lacks ornamentation; corpus bursae lacks signum. Recently two of the above mentioned specimens have been successfully barcoded and cluster into the same BIN as the already published specimen (BOLD Systems, accessed 10 December 2020). Further studies are necessary to clarify the exact taxonomic status.

Aristotelia subericinella (DUPONCHEL, 1843) is widely distributed in Europe and the Near East, extending eastwards to the Caucasus, southern Siberia and Mongolia (ELSNER et al. 1999: 23; JUNNILAINEN et al. 2010: 17). It is a species complex in need of taxonomic revision, a series of unnamed taxa formerly identified as $A$. subericinella were mentioned by HUEMER \& KARSHOLt (2020: 125) and HuEMER et al. (2020, supplementary material 2, NJ tree 11). In Romania predominantly old data are from Transylvania (RothsCHILD 1912a: 29), Dobrogea (POPESCU-GoRJ \& DRĂGHIA 1966: 186; POPESCU-GORJ et al. 1972: 186; SZÉKELY \& CERNEA 2007: 131), south-eastern Moldova (Olaru \& Nemeş 1969: 128; Nemeş \& Dănilă 1970: 185) and Oltenia (StǍNoIU \& CHIMIŞLIU 1993: 43). A re-examination of the collection materials is necessary, because some of the records may refer to the above mentioned undescribed taxa. Recently we collected the species in Dobrogea in large number in salt marshes of the Black Sea coastal area (Grindul Chituc), on limestone (Canaraua Fetii), in steppe habitats of the Transylvania Basin (Toldal, Lechinţa, Viişoara) and single specimens on mesophile mountain meadows (Ciuc Mountains) (legit \& coll. S. \& Z. Kovács). Recently one of the above mentioned specimens from Grindul Chituc was barcoded (TLMF Lep 27433) and clustered into the BIN BOLD:ADR8914 together with specimens from Austria (BOLD Systems, accessed 10 December 2020).

Aristotelia brizella (TReITSChKe, 1833) is a halophytic species confined to Armeria and Limonium species, widely distributed in Europe, North Africa and the Near East (ELSNER et al. 1999: 23). In Romania a single record is known from Craiova (Leamna forest, on Quercus in crevices of the trank, 15.VIII.1984, 6 §ึ) in Oltenia (STĂNOIU \& CHIMIŞLIU 1993: 43), which does not correspond with the ecological needs of the species. Its presence in Romania needs confirmation. 
Ptycerata ELY, 1910 is a senior synonym of Caulastrocecis CHRÉTIEN, 1931, with Holarctic distribution, comprising 9 Palaearctic and 1 Nearctic species (BIDZILYA \& KARSHOLT 2021), 7 species were recognized from Europe, two of them are recorded also from Romania and P. furfurella is deleted from the checklist. The recent changes in the systematics and nomenclature of the genus were not yet included in RÁkosy \& Goia (2021: 53).

Ptycerata pudicellus (MANN, 1861) is ranged in the Mediterranean, very local in central Europe, recorded also from Ukraine, Russia, Mongolia and Turkey (Bidzilya \& Karsholt 2021: 171). The species was described from one specimen from Turkey (Amasia) and two specimens from Romania (Mehadia) by ManN (1861: 190). There are two other old records from Dobrogea (MANN 1866: 355) and Crişana (Kovícs \& Kovács 2000: 21, 2001: 90). Recent data are not available.

Ptycerata cryptoxena (GozmÁNY, 1952) was described from Hungary (GozMÁNY 1952: 145, as Metzneria), synonymized with $P$. furfurella (Staudinger, 1871) by Englert (1974: 415), but recent molecular studies revealed that they are different species and P. cryptoxena was recalled from synonymy by Huemer \& KARSHOLt (2020: 86, 125). Barcoded specimens from Austria, Slovakia and Ukraine cluster into P. cryptoxena, specimens of $P$. furfurella were sequenced from Crimea (HUEMER et al. 2020, supplementary material 2, NJ tree 19) and the south-eastern part of European Russia (BOLD Systems, accessed 10 December 2020). It was recorded from Romania (Viişoara) very recently by BidZILYA \& KARSHOLT (2021: 163) and replaces $P$. furfurella in the latest Romanian checklist (RÁkosy \& GoIA 2021: 53). The latter species has been mentioned from Romania by Kovács \& Kovács (2000: 21, 2001: 89, as Caulastrocecis) only from two localities in Crişana (Ineu) and the Transylvanian Basin (Viişoara). No other collecting sites became known since then. Adults are restricted to steppe habitats and can be attracted to light. P. furfurella is deleted herewith from the Romanian checklist (see below in the list of the deleted species).

Megacraspedus ZelLer, 1839 is a Palaearctic genus, its taxonomy was very recently revised based on external characters, genitalia morphology and DNA barcodes, 85 species arranged in 24 species-groups were recognized. Confirmed host-plant records are only known for a few species, all belong to Poaceae (Huemer \& Karsholt 2018). A number of 59 species are known in Europe, from Romania 7 were recorded.

Megacraspedus similellus HUEMER \& KARSHOLT, 2018 was described from Bulgaria, Romania and Turkey (HuEMER \& Karsholt 2018: 46-48).
We examined the following material: Dobrogea, Jurilovca, Capul Doloşman, 16.VI.2012, genitalia slide GU 16/1470 Huemer, TLMF Lep 21298, 1 ภ, paratype; Dobrogea, Casimcei Plateau, Dobrogei Gorge, 20.VI.2016, genitalia prep. 2243/ $\delta /$ Kovács,

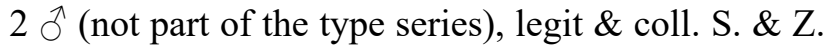
Kovács. All were attracted to light in steppe habitats on limestone at low altitude. Despite the barcoding data of the paratype were not mentioned neither in the revision of the Megacraspedus genus by HUEMER \& KARSHOLT (2018: 46) nor in the DNA barcode library for European Gelechiidae by HUEMER et al. (2020, supplementary material 2, NJ tree 35 ), they are public in the BOLD database, but ZMUC is erroneously mentioned as depository institution of the specimen (BOLD Systems, accessed 2 April 2020), correctly is coll. S. \& Z. Kovács.

Megacraspedus dolosellus (ZeLLER, 1839) is the most widely distributed species of the genus ranging from Western Europe to Central Asia. The species has also the largest regional and intrapopulational DNA barcode divergence reflected by 23 BINs. $M$. separatellus (FISCHER VON RöSLERSTAMM, 1843) is a junior synonym of $M$. dolosellus, its synonymy was motivated in details by HUEMER \& KARSHOLT (2018: 57). In Romania it was mentioned from Dobrogea already by MANN (1866: 355), later recorded from Banat (Hedemann 1897: 30; Rebel 1911: 413) and Transylvania (CzeKelius 1900: 153; RothSCHILD 1912a: 29). We collected the species in Transylvania in steppe habitats (Apuseni Mountains, Transylvanian Basin), but also on south-facing low mountain slopes without a characteristic steppe vegetation (Perșani and Ciuc Mountains). Two specimens from Rimetea were sequenced (HUEMER \& KARSHOLT 2018: 53) and they cluster into $M$. dolosellus E (BOLD:AAG0031) together with specimens from Hungary (HuEMER et al. 2020, supplementary material 2 , NJ tree 36 ). $M$. separatellus must be deleted from the most recent checklist of the Romanian Lepidoptera (RÁKOSY \& GoIA 2021: 53).

Megacraspedus devorator HUEMER \& KARSHOLT, 2018 was described recently based on four specimens collected in Bulgaria and a fifth in Romania (N Dobrogea, $5 \mathrm{~km}$ NE Ciucurova, 23.V.2009, genitalia slide GU 16/1461 Huemer, 1 , paratype, legit \& coll. J. Junnilainen). Externally resembles $M$. binotella, the biology is still unknown (HUEMER \& KARSHOLT 2018: 86-88). The paratype from Romania was sequenced (HuEMER et al. 2020, supplementary material 2, NJ tree 35). We examined the following material: Dobrogea, Hagieni forest, 22.VI.2016, genitalia prep. $2244 / \widehat{\delta} /$ Kovács, $2 \hat{\jmath}$, legit \& coll. S. $\&$ Z. Kovács. The type material was collected from late April to late May. We collected the species in late June. Adults were flying freely in the early morning above the grass in ruderal herb communities located 
between the agricultural fields and steppe habitats on limestone at low altitude. We presume, also the specimens published as M. binotella from Dobrogea, Banat, Moldova and Oltenia (see below) may belong to this species.

Megacraspedus binotella (DUPONCHEL, 1843) is distributed in central Europe (HUEMER \& KARSHOLT 2018: 90). It is a characteristic species of the exposed slopes in the Eastern (Bicaz Gorge, Perşani and Gurghiu Mountains) and Southern Carpathians (Bucegi Mountains), the Apuseni Mountains (Trascău Mountains), and in their pre-mountain hills in the Transylvanian Basin and Crișana: Feldru (Rothschild 1912a: 29), Cluj (Popescu-Gorj 1964: 33) and Ineu (KovÁcs \& Kovács 2001: 90). We found it most frequently in habitats on limestone substrate, with or without characteristic steppe vegetation, in the mountains up to $1800 \mathrm{~m}$. The Romanian Carpathians seem to be the south-eastern limit of its distribution. The species was recorded also from sites located outside of the Carpathian chain, from Dobrogea (environs of Tulcea) by Mann (1866: 355), Banat by HedemanN (1897: 30) and Rebel (1911: 413), Moldova (Suceava and Dolhasca) by Nemeş \& Lungoci (1973: 242) and Oltenia (Călimănești, Ocnele Mari, Corabia) by StĂNoIU \& CHIMIŞLIU (1993: 43), but all these specimens need re-examination because they may also refer to the only recently described and externally similar M. devorator (see above) or other related taxa. A record from Oltenia (Ocnele Mari) by SzÉKelY \& Cernea (2007: 130) was based on misidentification, which in fact refers to a Coleophora species.

Megacraspedus podolicus (ToLL, 1942) is widely distributed from Austria to the Altai Mountains in Russia, and it was recorded from Romania by HUEMER \& KARSHOLT (2018: 119-121). We examined the following material: Dobrogea, Grindul Chituc, Vadu, 17.VI.2012, genitalia slide 5323 Karsholt, 1 , det.

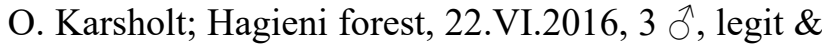
coll. S. \& Z. Kovács. The specimens were collected at light in the Black Sea coastal zone (Vadu) and a steppe habitat on limestone at low altitude (Hagieni).

Megacraspedus imparellus (FISCHER VON RöSLERSTAMM, 1843) is distributed in south-eastern Europe (HUEMER \& KARSHOLT 2018: 132). In Romania there is only an old literature data from Neamt Monastery in Moldova (CARADJA 1899: 206). A record from south-eastern Transylvania (Vlădeni) (SzÉKELY \& CERNEA 2007: 130) was based on misidentification, which in fact refers to a worn Yponomeuta specimen. Recently it was collected in steppe habitats in the Apuseni Mountains (Turda Gorge and the nearby Cheia, legit \& coll. S. \& Z. Kovács).

Megacraspedus argyroneurellus STAUDINGER, 1871 was recently recorded from Romania by
HUEMER \& KARSHOLT (2018: 119-121), representing the westernmost limit of its distribution. We possess the following material: Dobrogea, Casimcei Plateau, Dobrogei Gorge, 16.VII.2010, 1 §, det. O. Karsholt; 20.VI.2016, 1 ðૈ, legit \& coll. S. \& Z. Kovács. Both specimens were attracted to light in a steppe habitat on limestone at low altitude.

Psamathocrita MEYRICK, 1925 is anunsatisfactorily known genus although recently studied by HUEMER \& Tokár (2000). In the European fauna Huemer \& KARShOlt (2020: 126) mention 3 named species and 2 unnamed taxa. In Romania 2 species are recorded.

Psamathocrita osseella (STAINTON, 1860) has confirmed data only from the Great Britain, Germany, Sweden, Ukraine, Bulgaria and Croatia (HuEMER \& TOKÁr 2000: 8; AARviK et al. 2017: 74; Huemer et al. 2020 , supplementary material 2 , NJ tree 20 ). It was recorded from Romania without any more specific location by ELSNER et al. (1999: 26), from Dobrogea by Kovícs \& Kovács (2000: 23) and from Muntenia (Pasărea forest, 21.V.1982, as Psammathocrita) by AlBu \& AlBu (2020: 8). After the re-examination of the specimen from Dobrogea and its comparison with those treated by HuEMER \& TOKÁR (2000: 6) and HuEMER et al. (2020, supplementary material 2, NJ tree 20) we concluded that it was misidentified and in fact is $P$. argentella (see below). Consequently the symbol for Dobrogea must be deleted in RákosY \& GoIA (2021: 54). The specimen from Muntenia is a male without abdomen, its sequencing (TLMF Lep 28733) failed. The presence of the species in Romania needs confirmation.

Psamathocrita argentella Pierce \& Metcalfe, 1942 (Figs 24, 26) is distributed in Great Britain, France, Italy and Hungary (HuEMER et al. 2020, supplementary material 2, NJ tree 20). In Romania it was mentioned as $P$. osseella by Kovács \& Kovícs (2000: 23). After the re-examination of the specimen in the authors' collection we concluded that it was misidentified and is similar with an unidentified species mentioned by HUEMER \& TOKÁR (2000: 6), the genitalia best fit with the figures 9-10, a female from Hungary. Later the DNA sequencing of the Hungarian material revealed that it is $P$. argentella (HUEMER et al. 2020, supplementary material 2, NJ tree 20; Z. TOKÁR pers. comm.). First record for the Romanian fauna: Dobrogea, Băneasa, Rezervaţia Canaraua Fetii, 17.V.1994, genitalia prep. 1116/ $/$ Kovács, 1 \&, legit \& coll. S. \& Z. Kovács. The identification was confirmed by Z. Tokár (pers. comm.).

Ptocheuusa Heinemann, 1870 is a poorly known genus with 9 recognized species in Europe and probably further undescribed taxa (HUEMER \& KARSHOLt 2020: 89, 126). In Romania 3 species were recorded, but the presence of $P$. inopella (ZELLER, 1839) needs confirmation. 
Ptocheuusa paupella (ZELLER, 1847) (Figs 25, 27) is a locally recorded species from almost all Europe, Turkey, Israel and India (ElsNer et al. 1999: 26; JunNILAINEN et al. 2010: 22; PASTORÁLIS et al. 2018: 7; BiDZILYA et al. 2019a: 35), with 3 BINs in Europe (Huemer \& Karsholt 2020: 126). P. paupella and $P$. inopella are partly erroneously figured in ELSNER et al. (1999: colour plate 4): figure 45 is a male and $46 \mathrm{a}$ is a female of $P$. paupella, while figure $45 \mathrm{a}$ is the male and 46 is the female of $P$. inopella. First record for the Romanian fauna: Dobrogea, Grindul Chituc, Vadu, 30.VIII.2003, 2 o, 1 q; 17.VI. 2012, genitalia prep. 2071/ふ/ Kovács, 1 औ, legit \& coll. S. \& Z. Kovács; Grindul Chituc, Periboina, 29-30.VIII.2012, 3 ô, legit R. Kis \& I. Kovács, coll. S. \& Z. Kovács. The specimens were collected at light in salt marshes of the Black Sea coastal zone. Material collected in Romania has not yet been genetically examined.

Ptocheuusa inopella (ZELLER, 1839) is distributed in Europe, North Africa and the Near East (ELSNER et al. 1999: 26), with 3 BINs in Europe (HUEMER \& KARSHOLT 2020: 126). In Romania a record from Oltenia (STĂNOIU 1971) was considered doubtful by RÁkosY et al. (2003: 252). Another record from the Retezat Mountains (CĂPUŞE \& KováCS 1987: 58) was based on a misidentified gracillariid specimen

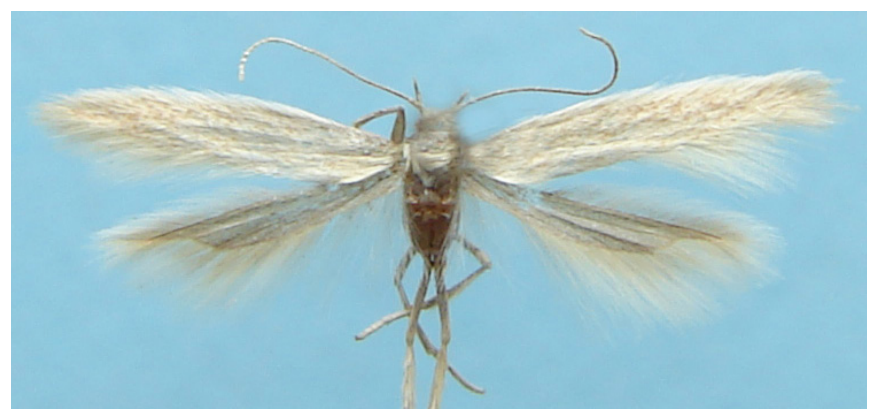

Fig. 24. Psamathocrita argentella Pierce \& Metcalfe, 1942: adult, female, wingspan $10.5 \mathrm{~mm}$, Dobrogea, Băneasa, Rezervaţia Canaraua Fetii, 17.V.1994, genitalia prep. 1116, legit \& coll. S. \& Z. Kovács.

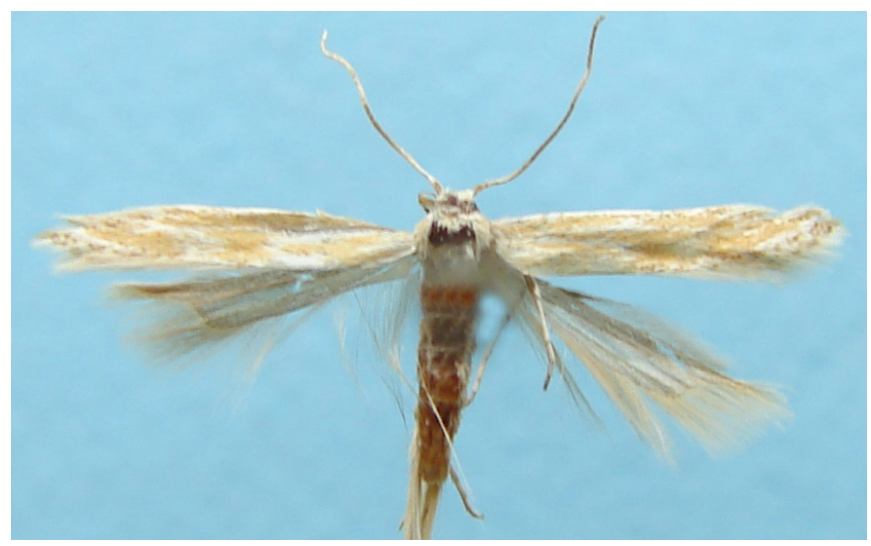

Fig. 25. Ptocheuusa paupella (ZELLER, 1847): adult, male, wingspan $11 \mathrm{~mm}$, Grindul Chituc, Periboina, 29-30. VIII.2012, legit R. Kis \& I. Kovács, coll. S. \& Z. Kovács.
(KovÁcs \& Kovícs 2000: 23). As the voucher material is untraceable the presence of the species in Romania needs confirmation.

Ptocheuusa abnormella (HERRICH-SCHÄFFER, $1854)$ is distributed in southern Europe, rarely recorded from central Europe (ELSNER et al. 1999: 26). In Romania there is a doubtful old record from Călimănești in Oltenia (STĂNoIU 1971; RÁKosy \& GoIA 2021: 214). Recently it was recorded only from the Apuseni Mountains (Turda Gorge) by Kovács \& Kovács (1994: 35) and the Transylvanian Basin (Viişoara) (Kovács \& Kovács 2000: 23; Kovács et al. 2002: 55, 80).

Ornativalva GozMÁNY, 1955 is Palaearctic in distribution; over 60 species are recognized following the revision of SATTLER (1976). In Europe 8, in Romania only 2 species are known.

Ornativalva ornatella SATTLER, 1967 is distributed in Romania, southern Russia, Turkey, Iran, Afghanistan and Mongolia; adults are on the wing from May to August (SATTLER 1976: 117). In Romania it was mentioned by SATTLER (op. cit.) based on a single specimen (Danube Delta, Sf. Gheorghe, 15.VIII.1971, genitalia prep. $686 / \widehat{\delta} /$ Sattler, 1 ठै, legit
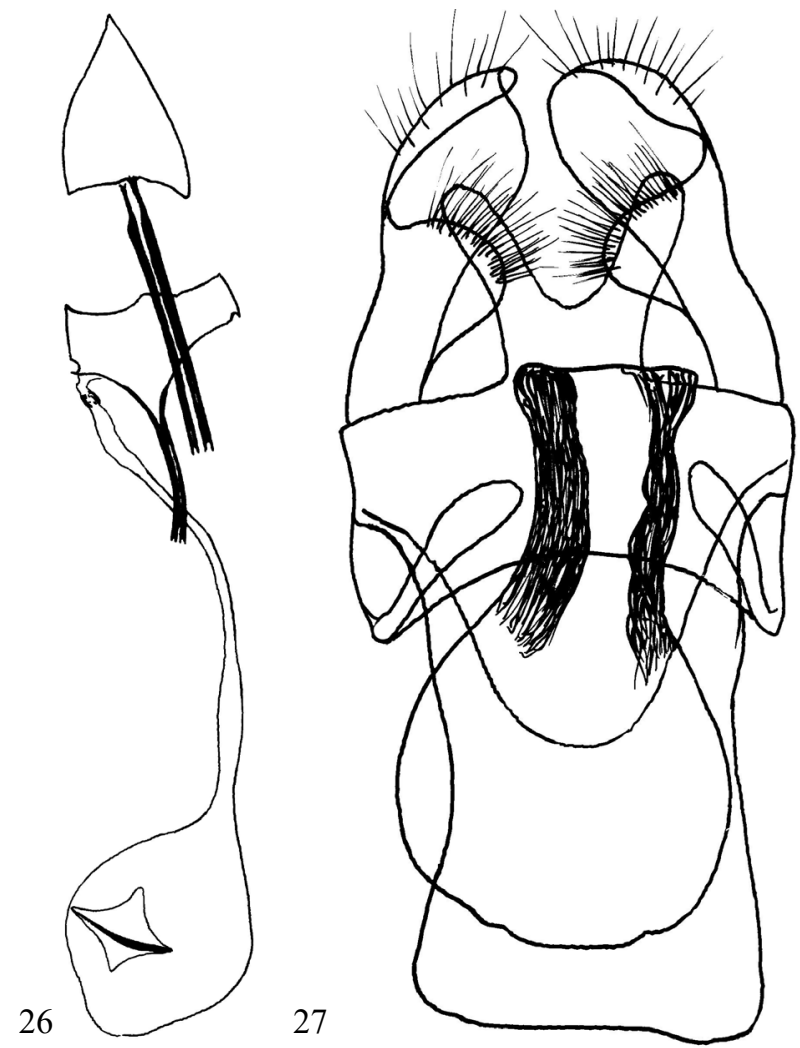

Figs 26-27. 26 - Psamathocrita argentella PIERCE \& MetCALFE, 1942: female genitalia in lateral view, genitalia prep. 1116, same data as Fig. 24 (left); 27 - Ptocheuusa paupella (ZELLER, 1847): free floating male genitalia in ventral view, Dobrogea, Grindul Chituc, Vadu, 17.VI. 2012, genitalia prep. 2071, legit \& coll. S. \& Z. Kovács (right). 
A. Popescu-Gorj, det. K. Sattler). The same data were published again by POPESCU-GoRJ (1985a: 113). A single additional specimen is known from the Măcin Mountains, Pricopan Peak, 150 m, 3-4.VIII.1994, genitalia prep. 1151/q/ Kovács, 1 , , legit \& coll. S. \& Z. Kovács (Kovács \& Kovács 2000: 25).

Ornativalva plutelliformis (STAUDINGER, 1859) is widely distributed in North Africa, throughout southern Europe from Spain to Ukraine and the Lower Volga region in Russia, extending eastwards to Iran, Central Asia, Pakistan and north-western China (BIDZILYA \& BudASHKIN 2017: 152). In Romania there are old data from Moldova (Drăgăneşti) (NEMEŞ \& DăNILĂ 1970: 184), old and recent data from Dobrogea (Eforie Sud, the Danube Delta: Caraorman, Grindul Letea) (PoPESCU-GorJ et al. 1972: 186; SATtLer 1976: 133; PopesCu-GorJ 1985b: 68) and Grindul Chituc (legit \& coll. S. \& Z. Kovács).

Atremaea Staudinger, 1871 is a monotypic genus with Palaearctic distribution (O. KARSHOLT pers. comm.).

Atremaea lonchoptera STAUDINGER, 1871 is distributed from southern and central Europe through Ukraine and the southern Ural Mountains to southern and western Siberia (ELSNER et al. 1999: 24; BIDZILYA \& BUDASHKIN 1998: 4; JUNNILAINEN et al. 2010: 20). In northern Europe recorded only from Denmark (AARVIK et al. 2017: 74). In Romania it was mentioned for the first time from Dobrogea (PoPESCU-GoRJ \& DRĂGHIA 1964), later from the Danube Delta (PoPESCU-GorJ 1976:161; 1985b: 68; POPESCU-GoRJ et al. 1972: 186; BoBîrnaC \& STǍNOIU 1975: 147), Oltenia (RÁKosY \& GoIA 2021: 54), the Razelm Lake (Dobrogea) and Gârboavele forest in south-eastern Moldova (SzÉKELY \& CERNEA 2007: 131). Recently collected specimens were recorded from Muntenia: Pasărea and Comana by SzÉKELY et al. (1999: 184), SzÉKELY (2011: 499) and Ilfov County by Albu \& Albu (2020: 10, as Atramaea). Solely on Letea in the Danube Delta was considered to be frequent during the day between 26.VI-28.VII (PoPESCU-GoRJ \& DrĂGHIA 1968: 237; POPESCU-GoRJ 1985b: 68); in all other sites only single specimens were collected. We examined a specimen collected in Bucharest (IOR Park, 10.VIII.1980, 1 đ, legit V. Albu, coll. S. \& Z. Kovács). It seems to be a characteristic species of reeds at low altitudes.

Isophrictis MEYRICK, 1917 is a poorly known genus, 12 species are recorded from Europe (HUEMER \& KaRShOlt 2020: 90). In Romania two species are known, larvae of both feed on Asteraceae. They are widely distributed, variable in size and colouration, and often difficult to recognize from external characters alone. A third recorded species, I. lineatellus (ZELLER, 1850 ) is not included in the checklist (see below in the list of the deleted species).
Isophrictis striatella ([DENIS \& SCHIFFERMÜLLER], 1775) is Holarctic in distribution (ELSNER et al. 1999: 22). In Romania it was mentioned from Dobrogea already by MANN (1866: 355), later recorded from most of the country except Muntenia (RÁKOSY \& GoIA 2021: 54). We collected it almost everywhere where its host-plants, Chrysanthemum corymbosum L. and Tanacetum vulgare L. are found. Adults rest during the day on the flowers or the stem of their host-plants and can easily be disturbed from there. They can also be attracted to light.

Isophrictis anthemidella (WOCKE, 1871) is distributed in Europe and central Asia (ELSNER et al. 1999: 22), genetically is variable, with three BINs in Europe (HuEMER \& KarSHOLT 2020: 127). In Romania it was mentioned only from Moldova (CARADJA 1899: 206; NeMEŞ \& DĂNILĂ 1970: 186), Transylvania (RothsChiLd 1912a: 29), Crişana (KovÁcs \& Kovács 2001: 90) and Muntenia (Albu \& Albu 2016: 77). The latter record has been omitted by RÁKosY \& GoIA (2021: 54). Probably it is present in the whole country, it can be found in the same conditions as I. striatella, but it is far not so widespread and frequent. Material collected in Romania has not yet been genetically examined.

Pyncostola Meyrick, 1917 is a genus with a concentration of the species in South Africa, only a few in Australia and one in Europe, including Romania.

Pyncostola bohemiella (NICKERL, 1864) is distributed in southern Europe, extending eastwards to the southern Ural Mountains, very local in central Europe (ELSNER et al. 1999: 24). In Romania the species was mentioned for the first time from the south-eastern part of Moldova (Gârboavele forest) by Olaru \& Nemeş (1969: 128), later recorded from Crişana (Ineu, legit \& coll. L. Diószeghy) and Dobrogea (Canaraua Fetii, legit \& coll. S. \& Z. Kovács) (Kovács \& Kovács 2000: 21). Recently only a few other Dobrogean sites (Măcin Mountains, Dobrogei Gorge, Histria, Vama Veche, legit \& coll. S. \& Z. Kovács) became known. The specimens were collected during the day in warm ruderal herb communities at low altitude or attracted to artificial light.

Metzneria ZELLER, 1839 is distributed in the Palaearctic region, M. lappella was introduced in North America. The larvae of the great majority of the species feed in flower heads of Asteraceae. The genus was revised by ENGLERT (1974) recognizing 27 species, but currently 32 described and a few unnamed species are already known from the Palaearctic region (BOLD Systems, accessed 12 April 2020). In Europe 24 species were recorded by HuEmer \& KARSHOLT (2020: 90), 10 of them are known from Romania and the presence of further cryptic species is suspected. 
Metzneria paucipunctella (ZELLER, 1839) is distributed in Europe (except the northern part), North Africa (ENGLERT 1974: 391), the Near East and Central Asia (ELSNER et al. 1999: 25). In Romania it was mentioned from Dobrogea already by MANN (1866: 355) and currently both old and recent data are known from most of the country except Banat and Muntenia (RÁkosy \& GoIA 2021: 54). The data from Turulung (ARDELEAN 1998: 170) are doubtful.

Metzneria neuropterella (ZELLER, 1839) is distributed in Europe (ENGLERT 1974: 393), the Caucasus, south and south-east Siberia, Mongolia and North Africa (ELSNER et al. 1999: 25; JUNNILAINEN et al. 2010: 21), in Europe it clusters into two BINs without geographical separation (HUEMER \& KARSHOLT 2020: 127). In Romania is known only from Moldova (Nemeş \& DĂNILĂ 1970: 186) and Transylvania (RÁKosY \& GoIA 2021: 213). A record from Turulung-Vii (ARDELEAN 1998: 170) is doubtful. One sequenced specimen from the Turda Gorge clustered into Metzneria neuropterella A (BOLD:AAH3862) together with specimens from Finland, Italy and North Macedonia (HUEMER et al. 2020, supplementary material 2, NJ tree 3; BOLD Systems, accessed 7 January 2021). We collected it in both mountain meadows and steppe habitats.

Metzneria aestivella (ZeLLER, 1839), the nominotypical subspecies is widely distributed in Europe and the Near East, and M. aestivella dichroa WALSINGHAM, 1908 is known from the Canary Islands (ENGLERT 1974: 395). In Romania only old data were known from Transylvania (CzeKELIUS 1918: 44) and Oltenia (STĂNoIU \& ChimişLIU 1993: 43). First record for Muntenia: Istrița, 740 m, 14.IX.2004, genitalia prep. 2492/ふో/ Kovács, 1 đૈ, legit N. Mușat, coll. V. Dincă.

Metzneria lappella (Linnaeus, 1758) is distributed throughout the Palaearctic region and it was introduced in North America (ELSNER et al. 1999: 25; JUNNILAINEN et al. 2010: 21). It is one of the most common species of the genus in Romania, recorded from Vâlcele (Transylvania) already by CzeKELIUs (1909: 162), currently known from the whole country (RÁKosy \& GoIA 2021: 54). The species inhabits ruderal herb communities.

Metzneria diffusella ENGLERT, 1974 (Figs 28-29) was described from southern Europe and the Near East. The host-plants are Centaurea diffusa Lam. and C. paniculata L. (ENGLERT 1974: 400). First record for the Romanian fauna: Dobrogea, Măcin Mountains, Pricopan Peak, 14-15.IX.1994, 1 \&; 27-28.VI.1997,

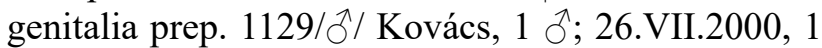
ग, 4 क; Grindul Chituc, Vadu (coast), 28.VII.2000, 4 ô, 4 क; Valea Casimcei, Cheia, 29.VII.2000, 1 O; Măcin Mountains, Greci, 23.VII.2011, 2 q;

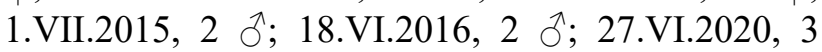

ठ; Enisala, 22.VII.2011, 3 đ, legit \& coll. S. \& Z. Kovács; Dobrogea, Grindul Chituc, Periboina, 8-9. VIII.2011, 2 ô, legit R. Kis \& I. Kovács, coll. S. $\&$ Z. Kovács. The flying period mentioned in the description of the species is from the beginning of June to August (ENGLERT op. cit.), but data published by JUNNILAINEN et al. (2010: 21) and our data reveal that the adults are on the wing also in September. It is widespread, but not common in Dobrogea.

Metzneria ehikeella GoZMÁNY, 1954 was described from Hungary, found in the southern and central parts of Europe, the Near East, central Asia, North Africa (ELSNER et al. 1999: 25; JUNNILAINEN et al. 2010: 21), and in most of the Nordic-Baltic countries (AARviK et al. 2017: 74). Barcoded specimens from Europe cluster into two BINs without geographical

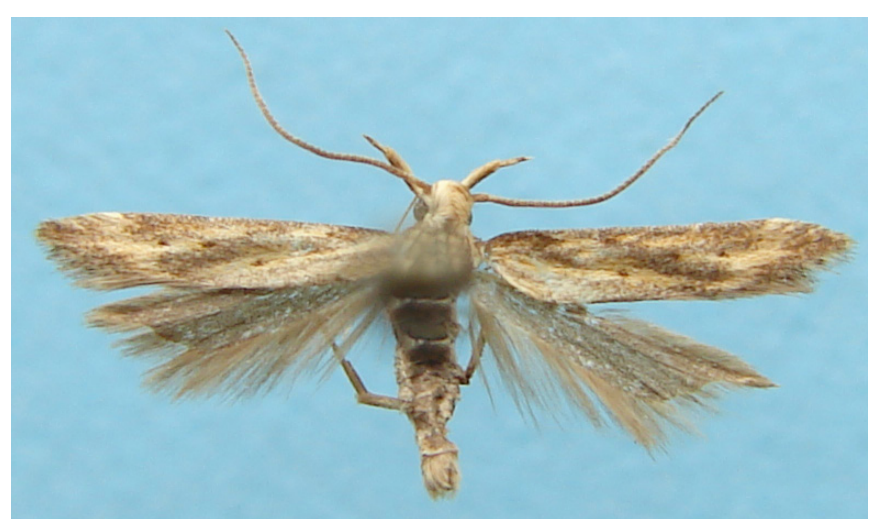

Fig. 28. Metzneria diffusella ENGLERT, 1974: adult, male, wingspan $12 \mathrm{~mm}$, Dobrogea, Grindul Chituc, Vadu, 28.VII.2000, legit \& coll. S. \& Z. Kovács.

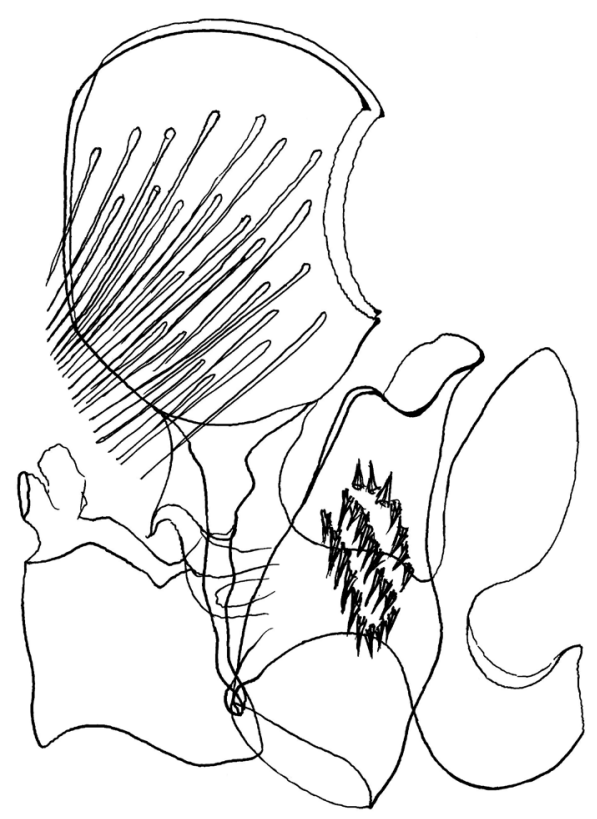

Fig. 29. Metzneria diffusella ENGLERT, 1974: free floating male genitalia in lateral view, Dobrogea, Măcin Mountains, Pricopan Peak, 27-28.VI.1997, genitalia prep. 1129, legit \& coll. S. \& Z. Kovács. 
separation (HUEMER \& KARSHOLT 2020: 127). It is rare in Romania, known from the Transylvanian Basin (Viişoara) (Kovács \& Kovács 2000: 23), the Apuseni Mountains (Turda Gorge) and the Eastern Carpathians (Racu), legit \& coll. S. \& Z. Kovács. Material collected in Romania has not yet been genetically examined. The specimens from Viişoara and the Turda Gorge slightly differ externally and in the male genitalia and may represent another species.

Metzneria metzneriella (STAINTON, 1851) is distributed in Europe, the Near East and southern Siberia (ElSNER et al. 1999: 25; JUNNILAINEN et al. 2010: 21). It is genetically variable with four BINs in Europe (HuEMER \& KARSHOLT 2020: 127). It is one of the most common species of the genus in Romania. Its first mention was from Moldova by CARADJA (1899: $205)$, currently is known from the whole country (RÁkosy \& GoIA 2021: 54). The species inhabits mainly the ruderal herb communities. Material collected in Romania has not yet been genetically examined.

Metzneria artificella (HERRICH-SCHÄFFER, 1861) is distributed from south-western Europe through central Europe to the Near East, Iran and southern Siberia (ENGLERT 1974: 407; JUNNILAINEN et al. 2010: 21), with two geographically separated BINs in Europe (HuEMER \& Karsholt 2020: 127). In Romania there are old data from Banat (ReBel 1927: 118, as pannonicella RBL.) and recent data from Dobrogea (KovÁcs \& Kovács 2000: 23, WIESER et al. 2000: 32; RÁKosY \& GoIA 2021: 214). Recently we collected only a few specimens attracted to light in steppe habitats of southern Dobrogea (Vama Veche, Jurilovca, Hagieni forest, Dumbrăveni, Cotu Văii). Material collected in Romania has not yet been genetically examined.

Metzneria aprilella (HERRICH-SCHÄFFER, 1854) is widely distributed in most of Europe, Turkey, Kazakhstan, Uzbekistan, Iran and southern Siberia (JUNNILAINEN et al. 2010: 21), in Europe with three geographically separated BINs (HUEMER \& KARSHOLT 2020: 127). In Romania it was mentioned for the first time from Dobrogea by MANN (1866: 355), later recorded from Transylvania (CzeKelius 1918: 44), Oltenia (STĂNoIU \& ChimişliU 1993: 43) and Crişana (Kovács \& KovÁcs 2001: 90). The symbol for Banat in RÁKosY \& GoIA (2021: 54) must be deleted, because the species was recorded from the former Danube island (Temes sziget) by RoTHSCHILD (1912c: 178), currently Ostrovo village in modern Serbia. It is a species with variable male genitalia and in mean time a species-complex (O. KarSHOLT pers. comm.). There are three slightly different male genitalia figured in different literature sources, with angular cucullus and conical sacculus in ENGLERT (1974: 409), with slender cucullus and subtriangular sacculus from the Czech Republic in ElSNER et al. (1999: plate 5, fig. 40), and with rounded cucullus and subtriangular sacculus from Austria on the website of LEPIFORUM (accessed 1 December 2020). We examined a male from Transylvania similar with that figured by ENGLERT and specimens from Dobrogea best fitting to that figured in LEPIFORUM. Recently a specimen from Dobrogea was successfully barcoded (TLMF Lep 27432) which clustered into the BIN BOLD:ABW0030 together with specimens from Italy and Croatia (BOLD Systems, accessed 7 January 2021).

Metzneria intestinella (MANN, 1864) is distributed in southern Europe and the Near East (BIDZILYA \& BUDASHKIN 2017: 152). It is a rare species in Romania, found only in warm and dry habitats of the southern and western parts of the country. It was recorded from Dobrogea (MANN 1866: 355; ENGLERT 1974: 412) and Crişana (RoTHSCHILD 1913: 80; Kovács \& Kovács 2001: 91). Recently it was collected from Dobrogea (Canaraua Fetii, Lespezi, Capidava, Capul Doloșmani, Dobrogei Gorge, Măcin Mountains), Muntenia (Balta Albă, 3.V.2018, 1 đ̋), legit \& coll. S. \& Z. Kovács, and according to RÁKOsY \& GoIA (2021: 54) from Transylvania. It is the first record for Muntenia.

Apodia Heinemann, 1870 comprises only two species in Europe (HuEMER \& KARSHOLt 2020: 92), both recorded from Romania, but $A$. martinii needs confirmation.

Apodia bifractella (DUPONCHEL, 1843) is distributed in Europe, the Near East and North Africa (ELSNER et al. 1999: 26). In Romania it was mentioned from Dobrogea (MANN 1866: 355), Banat (Hedemann 1897: 30; Rebel 1911: 413), Transylvania (CzeKelius 1918: 45), Crişana and the Retezat Mountains (GozMáNY 1953: 183; Kovács \& Kovács 2001: 91). Recently it was collected from Dobrogea, Banat and Transylvania (legit \& coll. S. \& Z. Kovács). In Romania is a common species, can be found especially in warm sites, adults often rest on the flowers of the host-plants, different Inula species.

Apodia martinii Petry, 1911 was recorded only from Germany, Latvia, Austria (KARSHOLT 1995: 145), Finland and Italy (HUEMER et al. 2020, supplementary material 2, NJ tree 9). Its taxonomic status has long been considered unclear, but it seems to be genetically well defined (HuEMER \& KarSHOLt 2020: 127). In Romania GozMÁNy (1958: 264) recorded it from Ineu (Crişana) without further details, but the record was overlooked and the species not included in the checklists (PoPeSCU-GorJ 1984; Kovács \& KováCS 2000; RÁKosy et al. 2003; RÁKosY \& Goia 2021). We consider its presence doubtful, which needs confirmation. 
Pragmatodes Walsingham, 1908 for a long time has been considered monotypic, endemic to the Canary Islands. Recently a group of closely related species with larvae feeding on Rubiaceae, earlier placed under, but do not fitting well with Monochroa were transferred into this genus by HUEMER \& KaRSHOLT (2020: 128). In Europe 5 species are known, in Romania only one was recorded.

Pragmatodes parvulata (GoZMÁNY, 1953) is a poorly known central and southern European species distributed from France to Estonia (ELSNER et al. 1999: 29 ) and the southern Ural Mountains (JUNNILAINEN et al. 2010: 26). In Romania it was recorded very recently as Pragmatodes parvulata (BOLD:ACB9409) by HUEMER et al. (2020, supplementary material 2, NJ tree 9) from Dobrogea, Şipotele, KLM Lep 06010, 17.VII.2015, legit C. Wieser, coll. LMKK (BOLD Systems, accessed 10 October 2020). In the most recent Romanian checklist (RÁKosY \& GoIA 2021: 54) still mentioned as a Monochroa species.

Argolamprotes BenANDER, 1945 is a monotypic genus with Palaearctic distribution (O. KARSHOLT pers. comm.).

Argolamprotes micella ([DENIS \& SCHIFFERMÜLLER], 1775) is widespread across most of the Palaearctic region except the southern parts (ELSNER et al. 1999: 26). In Romania it was recorded only from Muntenia (Azuga) (CARADJA 1902: 617), Moldova (Tișiței Gorge) (RÁKosy et al. 1998: 21) and Transylvania (RÁKosY 2002: 66). It is widespread but not frequent in the mountains where the larval hostplants, the Rubus species are most abundant; we found it in several sites in the Eastern Carpathians.

Monochroa HeInEmanN, 1870 is a species rich, but poorly known genus, requiring revision. There are already known from Europe a series of unnamed species and many other are considered to be species-complexes (ElSNER et al. 1999: 27, 29; HuEMER \& Karsholt 2020: 128; Huemer et al. 2020, supplementary material 2 , NJ tree 41 ). Despite the species are mono- or oligophagous, on generic level extremely different plant species are used, from ferns (Pteridaceae) through monocotyledonous (Juncaceae, Cyperaceae) to dicotyledonous plants (Polygonaceae, Primulaceae, Rosaceae, Iridaceae). In Europe 31 described species were recorded, in Romania 16 are known.

Monochroa rumicetella (O. HOFMANN, 1868) is widespread across most of Europe except the northernmost and southernmost parts (ELSNER et al. 1999: 26). In Romania there are only two old data from Grumăzeşti in Moldova (CARADJA 1901: 153) and Ineu in Crişana (Kovács \& Kovács 2001: 91).
Monochroa sepicolella (HERRICH-SCHÄFFER, 1854 ) is thought to have a northern European distribution and in central and southern Europe may be replaced with $M$. rectifasciella (FucHS, 1902) (e.g. Śumpich 2011: 111). ELSNER et al. (1999: 27) considered M. sepicolella a species-complex, and this concept currently is supported also by the results of the genetic studies, however, further studies are necessary to clarify the correct taxonomic status (HuEMER \& Karsholt 2020: 128). Two other taxa treated as synonyms of $M$. sepicolella, but not mentioned by Huemer \& Karsholt (2020: 92), Anacampsis balcanica REBEL, 1903 (described from Sliven in Bulgaria) (GozmánY 1957: 128) and Aristotelia (Xystophora) agasta Gozmány, 1954 (the type locality is near Kaposvár in south-western Hungary) (GozmánY 1954: 277), must also be taken into account. The currently available genetic data suggest that all the above mentioned names probably refer to the BIN BOLD:AAU2813 and the specimens from northern Europe (Norway, Finland, Latvia), which cluster into the BIN BOLD:AAF8604 may represent a different species (BOLD SYsTEMs, accessed 13 January 2021). In Romania it was recorded from Transylvania, Banat (ReBel 1911: 412, as Anacampsis balcanica RBL.; GozmánY 1957: 128), Crişana (KovÁcs \& Kovícs 2001: 91) and very recently as Monochroa sepicolella A (BOLD:AAU2813) from Dobrogea, Șipotele, KLM Lep 06008, legit C. Wieser, coll. LMKK (HUEMER et al. 2020, supplementary material 2, NJ tree 41; BOLD SYSTEMS, accessed 7 January 2021). We examined the following recently collected material: Dobrogea, Enisala 28.VIII. 2012, genitalia prep. 2019/ふ/ Kovács, 1 $\widehat{~}, 1$ ค, legit R. Kis \& I. Kovács, coll. S. \& Z. Kovács; Dobrogea, Măcin Mountains, Greci, 18.VI.2016, genitalia prep. 2018/ふ/ Kovács, 1 ふै; Dobrogea, Casimcei Plateau, Cheia, 20.VI.2016, genitalia prep. 2019/9/ Kovács (similar with the figure 53a of the plate 47 in ELSNER et al. 1999), TLMF Lep 27430, 1 q, legit \& coll. S. $\&$ Z. Kovács. The latter specimen was barcoded and clustered into the same BIN with the other sequenced specimen from Romania.

Monochroatenebrella (HÜBNER, 1817) is a European species (ELSNER et al. 1999: 27). In Romania known only from a few, mainly old specimens taken in Sibiu, Ocnele Sibiului and the Cibin Mountains (Czekelius 1901: 87), the Retezat Mountains (Diószeghy 1930a: 285) and Azuga (Muntenia) (CARADJA 1902: 617). A record from Ineu by CĂPUŞE \& Kovács (1987: 58) was not confirmed during the revision of the Gelechiidae in the L. Diószeghy collection, the re-examined specimens proved to be Aproaerema coronillella and A. sangiella (Kovícs \& Kovícs 2001: 91, 97, 98). Consequently the symbol for Crişana must be deleted in Rákosy \& GoIA (2021: 55). A single male was collected recently in the southern part of the Harghita Mountains (legit \& coll. S. \& Z. Kovács). 
Monochroa servella (ZELLER, 1839) is distributed in all Europe and the Near East (ELSNER et al. 1999: 27). In Romania only old data were known from Crişana (Ineu) (Kovács \& Kovács 2000: 23; 2001: 91). First record for Transylvania: Eastern Carpathians, Harghita Mountains, Királykútja, 1000 m, 26.V.2002, genitalia prep. 2049/ふ/ Kovács, 1 đ; Ciuc Mountains, Racu, Cseretető, 1.VI.2002, 1 సं; 8.VI.2004, 1 §; 20.VII.2004, genitalia prep. 2427/§/ Kovács, 1 đ; 16.VII.2021, 1 đ;; Perşani Mountains, Vârghiş Gorge, 6-7.VII.2002, 2 ภં; 21.VI.2003, genitalia prep. 2175/ふ/ Kovács, 1 đ; 5-7.VII.2004, 2 ठै; 12.VI.2010, genitalia prep. 2048/ठ/ Kovács, 1 đ; 6-7.VI.2014, genitalia prep. 2029/ठ/ Kovács, 3 ô; Glodeni (Mureş County), 20.VIII.2008, genitalia prep. 2054/ठ̂/ Kovács, 1 đิ; Bârsei Depression,

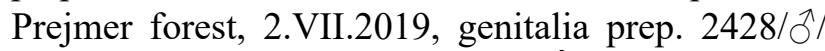
Kovács, 1 ð’; Apuseni Mountains, Întregalde Gorge, 17.VI.2006, 1 đ; Metaliferi Mountains, Râmeţ, 1100 m, 11.V.2018, genitalia prep. 2028/ $/$ Kovács, $2 \curvearrowright$, legit \& coll. S. \& Z. Kovács.

Monochroa conspersella (HERRICH-SCHÄFFER, 1854) (Figs 30-31) is distributed in Europe, but rarely recorded in the southern parts (ELSNER et al. 1999: 27). In Romania it was recorded from its mine on Lysimachia nummularia L. from Petrești forest (Vrancea County, Moldova) by NeAcşu \& DrĂGHIA (1973: 196, 200, as Monochroa (Xytophaga) morosa MuHL.), but later the record was overlooked and the species not included in the checklists (POPESCU-GORJ 1984; Kovács \& KovÁcs 2000; RÁKosY et al. 2003; RÁKosy \& GoIA 2021). Now we confirm its presence in the Romanian fauna with voucher material collected in the Eastern Carpathians: Giurgeu Depression, Voşlăbeni, Szenéte, $760 \mathrm{~m}, 10-13 . V I I .2002$, genitalia prep. $2041 / \widehat{\partial}$ and 2042/ð/ Kovács, $2 \hat{\jmath}, 1$ o; 25.VII.2004, genitalia prep. 2043/ $/$ Kovács, 1 ô; 20.VII.2007, 1 ठ; 10.VII.2017, genitalia prep.

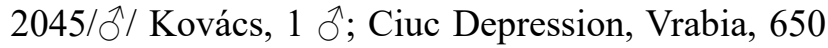
m, 8.VII.2006, genitalia prep. 2033/ð/ Kovács, $2 \precsim$, legit \& coll. S. \& Z. Kovács. All of the specimens were attracted to light in flat moors. It is the first record for Transylvania.

Monochroa elongella (HEINEMANN, 1870) is distributed in Europe extending eastwards to Siberia (ELSNER et al. 1999: 27; JUNNILAINEN et al. 2010: 23). In Romania it was recorded for the first time based on specimens from Ineu in Crişana (Kovács \& Kovács 2000: 23; 2001: 91). Recent data are available only from the Transylvanian Basin (environs of Târgu Mureş, legit \& coll. V. Vicol) (RÁKosy \& Goia 2021: 214) and it was collected in the Eastern Carpathians (Racu, legit \& coll. S. \& Z. Kovács).

Monochroa inflexella SVENSSON, 1992 is distributed in Europe (ELSNER et al. 1999: 27). In Romania it was recorded based only on a single male specimen collected in Ineu (Crişana) by L. Diószeghy (Kovícs \& KovÁcs 2000: 23; 2001: 91). No further data became available since then.

Monochroa tekovella Kosonín, 2020 (Figs 3233) was described very recently; the type material originates from Slovakia, the Czech Republic and Bulgaria (Kosonín 2020). First record for the Romanian fauna: Apuseni Mountains, Trascău Mountains, Piatra Secuilor (Rimetea), 5.VII.2000, 1 ठึ; Dobrogea, Măcin Mountains, Greci, 250 m, 26.V.2007, genitalia prep. 2022/ふ/ Kovács, 2 ठૈ; 15.VI.2012, 1 đ; Baraolt Mountains, Ariuşd, Csókás, 600 m, 13.VI.2015, genitalia prep. 2173/ $\widehat{~} /$ Kovács, TLMF Lep 27431, 1 ○̂, legit \& coll. S. \& Z. Kovács, coll. TLMF, coll. ZMUC. All of the specimens were collected at light in xerothermic mountain meadows.

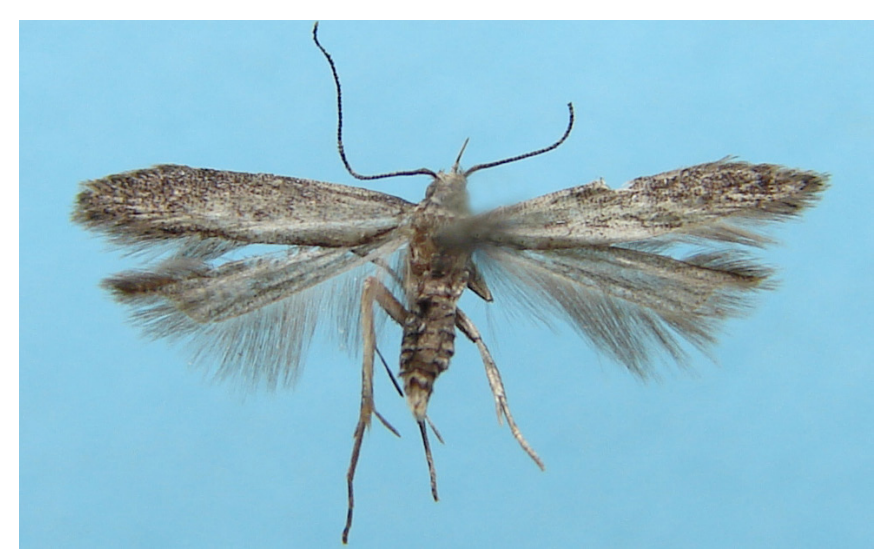

Fig. 30. Monochroa conspersella (HERRICH-SCHÄFFER, 1854): adult, male, wingspan $11 \mathrm{~mm}$, Eastern Carpathians, Giurgeu Depression, Voşlăbeni, Szenéte, 760 m, 10.VII.2017, legit \& coll. S. \& Z. Kovács.

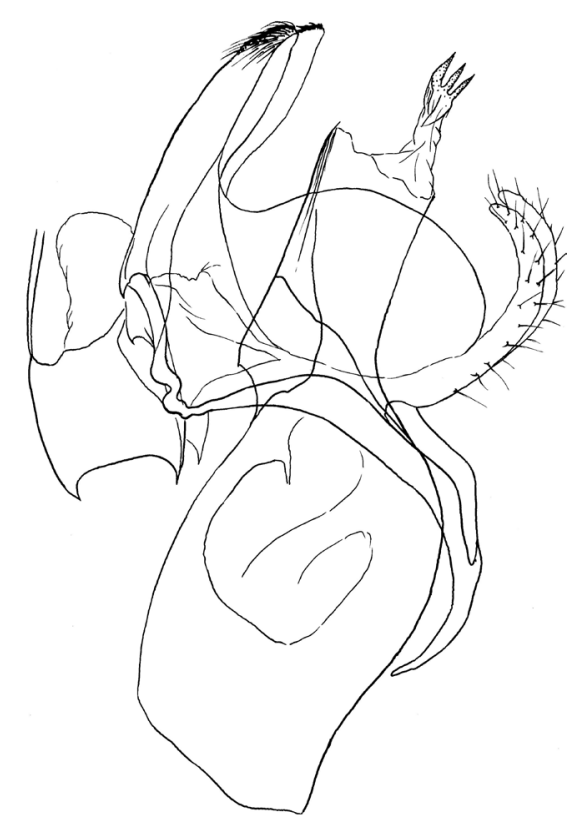

Fig. 31. Monochroa conspersella (HERRICH-SCHÄFFER, 1854): free floating male genitalia in lateral view, Eastern Carpathians, Ciuc Depression, Vrabia, 650 m, 8.VII.2006, genitalia prep. 2033, legit \& coll. S. \& Z. Kovács. 
A recently barcoded specimen clustered into the BIN BOLD:ADL7906 together with specimens from Slovakia, Bulgaria and Poland (BOLD Systems, accessed 2 December 2020).

Monochroa lutulentella (ZELLER, 1839) is distributed in northern, central and eastern Europe (ELSNER et al. 1999: 27; JUNNILAINEN et al. 2010: 24). It is known from Romania with old data from Moldova (Nemeş 1974: 209) and Crişana (Kovács \& Kovács 2001: 91). Recently recorded from Satu Mare (Foieni, Porumbeşti) (Ardelean 1998: 169) (doubtful data), and it was collected in the Transylvanian Basin (Glodeni), Eastern Carpathians (Voşlăbeni, Racu, Vrabia, Băile Tuşnad, Lisnău) and Banat (Băile Herculane, 250 m, 16.VI.2021, genitalia prep. $2430 / ð /$ Kovács, 2 ঐ), legit \& coll. S. \& Z. Kovács. It is the first record for Banat.

Monochroa palustrellus (Douglas, 1850) is distributed in western, northern and central Europe

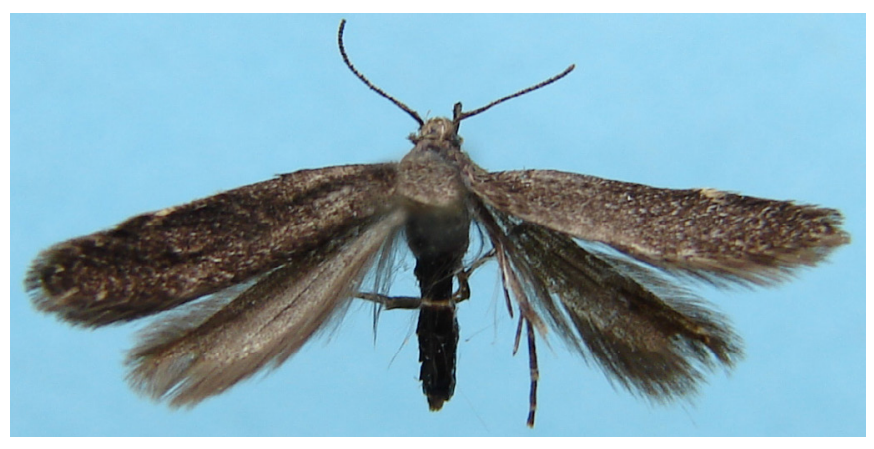

Fig. 32. Monochroa tekovella Kosorín, 2020: adult, male, wingspan 13.5 mm, Dobrogea, Măcin Mountains, Greci, 250 m, 26.V.2007, legit \& coll. S. \& Z. Kovács.

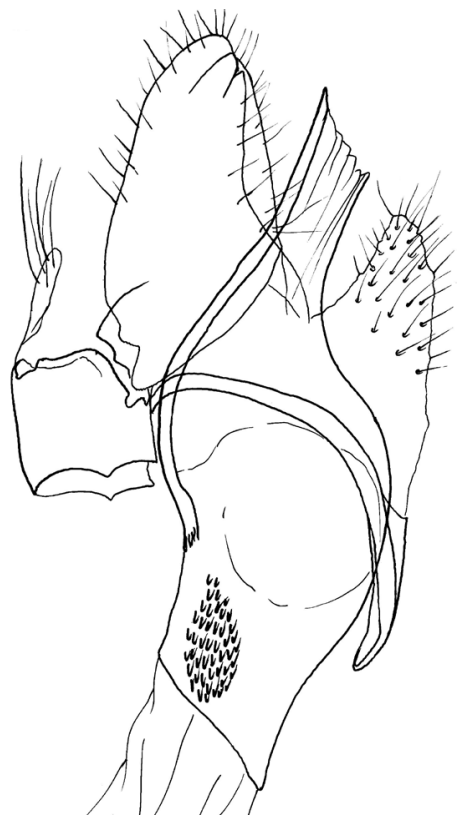

Fig. 33. Monochroa tekovella Kosorín, 2020: free floating male genitalia in lateral view, genitalia prep. 2022, same data as Fig. 32. and southern Siberia (ELSNER et al. 1999: 27; JUNNILAINEN et al. 2010: 24). In Romania it was recorded only from the Danube Delta (Caraorman, Grindul Letea) (PoPescu-GorJ 1970: 92, 1985b: 68; POPESCU-GorJ et al. 1972: 186).

Monochroa divisella (Douglas, 1850) is distributed throughout the northern and central parts of the Palaearctic region (JunNILAINEN et al. 2010: 24). In Romania it was recorded from Banat (environs of Svinița, Treskavac, 24.VII.1911, 1 đ) by RotHSCHILD (1912b: 179, as Catabrachmia csornensis RBL.), but the record was overlooked and not included in the earliar Romanian checklists (POPESCU-GorJ 1984: 127; Kovács \& Kovács 2000: 14; RÁKosY et al. 2003: 62), only in the most recently by RÁKosY \& GoIA (2021: 55). We examined voucher material collected in Dobrogea (Hagieni forest, 22.VI.2016, genitalia prep. $2126 / \delta /$ Kovács, 1 ठ, legit \& coll. S. $\&$ Z. Kovács). The specimen was attracted to light. It is the first record for Dobrogea.

Monochroa lucidella (STEPHENS, 1834) is locally distributed in Europe, the Near East and Siberia (ElSNER et al. 1999: 27; JUNNILAINEN et al. 2010: 24). In Romania old data are available from Moldova (CARAdja 1901: 153), Transylvania (CzeKelius 1918: 45), the Danube Delta (Popescu-GorJ \& DrĂGHIA 1968: 235; PoPESCU-GorJ et al. 1972: 186) and Crişana (Kovícs \& Kovács 2001: 91). Recently it was collected from the Eastern Carpathians (Sfântu Gheorghe, Mestecănişul de la Reci) and Dobrogea (Grindul Chituc) (legit \& coll. S. \& Z. Kovács). A barcoded specimen from Dobrogea clusters together with specimens from western and northern Europe in the BIN BOLD:ABX6146, but with $0.97 \%$ p-distance (BOLD Systems, accessed 7 January 2021).

Monochroa suffusella (Douglas, 1850) is distributed in northern and central Europe (ELSNER et al. 1999: 27). In Romania it was recorded only from the Mohos peat bog in the southernmost part of the Harghita Mountains in the Eastern Carpathians (KovÁcs \& Kovács 2000: 25). Later it was collected again in the same site and in a flat moor at Prejmer in the Bârsei Depression (2.VII.2019, 1 Oे, legit \& coll. S. \& Z. Kovács).

Monochroa cytisella (CURTIS, 1837) is widespread in the northern and central parts of the Palaearctic region (ELSNER et al. 1999: 26). In Romania it was known from Moldova (Nemeş \& LunGoci 1973: 242, as Paltodora) and Transylvania (RÁKosy et al. 2003: 62, based on unpublished data, legit \& coll. S. \& Z. Kovács, see below). The data from Satu Mare (ARDELEAN 1998: 170) are doubtful. A record from Ineu (Crişana) by CĂPUŞE \& KovÁcs (1987: 57) proved to be incorrect, the study of the genitalia confirmed M. rumicetella (Kovícs \& Kovács 2001: 
91); consequently the symbol for Crişana in RÁKosy \& Goia (2021: 54) must be deleted. We examined the following material: Eastern Carpathians, Harghita Mountains, Băile Jigodin, 650 m, 29.VII.1999, genitalia prep. 1117/\&/ Kovács, 1 đૈ, 1 \&; Harghita Mountains, Miercurea Ciuc, 700 m, 5.VII.2003, 2 2 q; Harghita Mountains, Beta valley, 25.VII.2003, 7 đ; 27.VII.2003, 3 ô, legit \& coll. S. \& Z. Kovács. In Romania it is not frequent, despite its host plant, Pteridium aquilinum (L.) Kuhn is very common and widespread in the mountain zone.

Monochroa nomadella (ZELLER, 1868) is distributed in southern, central and eastern Europe and Mongolia (ELSNER et al. 1999: 27; JUNNILAINEN et al. 2010: 25); it is probably a species-complex (HuEMER \& Karsholt 2020: 129). In Romania it was recorded only from Dobrogea (Canaraua Fetii) and Transylvania (Turda Gorge and Viișoara) (Kovícs \& KovÁcs 2000: 25), recent material is available only from the Baraolt Mountains (Ariușd) and Apuseni Mountains (Scăriţa-Belioara), legit \& coll. S. \& Z. Kovács. Material collected in Romania has not yet been genetically examined.

Monochroa hornigi (STAUDINGER, 1883) is distributed in Europe (ELSNER et al. 1999: 27). In Romania is one of the most widespread species. There are old data from Transylvania (Sibiu) (Czekelius 1924: 256), Crişana (Ineu) (Kovács \& Kovács 2001: 91), Muntenia (Azuga) (CARADJA 1902: 617) and Moldova (Dolhasca) (PoPeSCu-GorJ \& Nemeş 1965: 157). Data from Satu Mare (Turulung-Vii, Noroieni forest) (ARDELEAN 1998: 170) are doubtful. Recently it was collected from Dobrogea (Canaraua Fetii, Hagieni forest), Transylvania (Racu, Vârghiș Gorge) and Muntenia (Mihai Bravu), legit \& coll. S. \& Z. Kovács.

Oxypteryx ReBeL, 1911 is a senior synonym of Eulamprotes BRADleY, 1971 (BIDZILYA et al. 2019a: 35 ), it is a poorly known genus. Despite the $O$. libertinella species-group was revised by HUEMER \& KARSHOLT (2011) and the $O$. wilkella species-group by HuEmer et al. (2013), the genetic studies indicate further diversity and the genus needs revision again (Huemer \& Karsholt 2020: 129). Currently 19 species are known from Europe, from Romania 9 were recorded, but $O$. nigritella (ZELLER, 1847), $O$. libertinella (ZELLER, 1872) and O. nigromaculella (MiLlière, 1872) were deleted from the checklist (see below in the list of the deleted species).

Oxypteryx wilkella (LinNAEUs, 1758) is widely distributed from Western Europe to the Russian Far East (HuEmer et al. 2013: 74-76), with two BINs in Europe (HuEMER \& KaRsholt 2020: 129). It is known from Romania based only on a very old record from Moldova (CARADJA 1899: 204) and recently taken specimens from Dobrogea (Canaraua Fetii, Măcin Mountains, Sarichioi) and Transylvania (Mestecănișul de la Reci, Pociovaliștei Gorge), legit \& coll. S. \& Z. Kovács. In the database of the BOLD Systems (accessed 13 November 2021) there is a single Romanian specimen whiches sequencing failed, RÁKosy \& Goin (2021: 288) treat this data as one referring to Eulamprotes libertinella (ZELLER, 1872) (see also below in the list of the deleted species).

Oxypteryx ochricapilla (REBEL, 1903) is only known in scattered localities in Europe: southern France, northern Italy, Austria, Czech Republic, Slovakia, Romania and Bulgaria (HuEmer et al. 2013: 77). In Romania only a single old specimen was mentioned from Ineu (Crişana) by Kovács \& Kovács (2000: 25; 2001: 91). First record for Dobrogea: Casimcei Plateau, Cheia, 29.VII.2000, genitalia prep. 2068/\&/ Kovács, 1 +; Măcin Mountains, Greci, 150250 m, 10.VIII.2001, genitalia prep. 2069/ $/$ / Kovács,

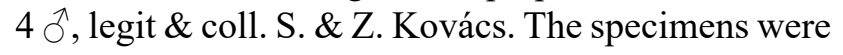
attracted to light.

Oxypteryx superbella (ZELLER, 1839) is distributed in Europe, North Africa, Turkey, extending eastwards as far as to Mongolia (HuEMER et al. 2013: 79). It was known from Romania based only on a very old record of CARADJA (1899: 204) from Moldova. First record for Transylvania: Eastern Carpatians, Baraolt Mountains, Ariuşd, Vecer, 600 m, 22.V.2009, genitalia prep. 2067/ð/ Kovács, 1 đ; Perşani Mountains, Vârghiş Gorge, 27.V.2009, genitalia prep. 2086/ and 2085/ $/$ / Kovács, 3 §, 2 o; 26.VI.2016, genitalia prep. 2066/ðै/ Kovács, 8 कै, legit \& coll. S. \& Z. Kovács. The specimens were attracted to light.

Oxypteryx unicolorella (DUPONCHEL, 1843) is widely distributed in most of Europe except the southern parts (ELSNER et al. 1999: 29). In Romania old material is known from Transylvania (Sibiu) (Czekelius 1909: 163), the Retezat Mountains and Crişana (Ineu) (Diószeghy 1935: 124; Kovács \& KovÁcs 2001: 92). Recently collected specimens are from the Eastern Carpathians (Perșani, Harghita, Ciuc, Gurghiu and Giurgeu Mountains, Bicaz Gorge, Bârsei and Giurgeu Depressions), Transylvanian Basin (Lechința), Apuseni Mountains (Întregalde Gorge) and Banat (Băile Herculane, 250 m, 16.VI.2021, 1 đ; Dubova, 200-300 m, 17.VI.2021, 1 + , legit \& coll. S. \& Z. Kovács). It is the first record for Banat.

Oxypteryx atrella ([DENIS \& SCHIFFERMÜLLER], 1775) is widespread across most of Europe except the southern parts (ELSNER et al. 1999: 29). Old Romanian data are from Muntenia (Azuga) (CARADJA 1902: 617), Transylvania (Czekelius 1918: 45), Crişana (Ineu) (Kovícs \& Kovícs 2001: 92) and Moldova (RÁKosy \& GoIA 2021: 55). Recently it was collected from the Eastern Carpathians (Harghita, Perșani and 
Ciuc Mountains, Giurgeu, Trei Scaune and Bârsei Depressions), Transylvanian Basin (Toldal) and Apuseni Mountains (Scărița-Belioara) (legit \& coll. S. \& Z. Kovács).

Oxypteryx plumbella (HEINEMANN, 1870) is distributed only in Scandinavia, the Baltic countries and central Europe (ELSNER et al. 1999: 30; AARVIK et al. 2017: 75). It was mentioned from Romania only from Ineu (Crişana) by Kovács \& Kovács (2000: 25 and fig. 10, 2001: 92) based on 3 males collected by L. Diószeghy. First records for Dobrogea and Transylvania: Dobrogea, Măcin Mountains, Pricopan peak, 14-15.IX.1994, genitalia prep. 2495/ $/$ / Kovács, 1 क; Dobrogea, Dobrogei Gorge, 27.VIII.1999, genitalia prep. 1190/क/ Kovács, 1 O; Transylvanian Basin, Viişoara (Câmpia Turzii), 28.VI.2003, genitalia prep. 2122/ / / Kovács, 1 q, det. O. Karsholt; Lechința (Mureș County), 13.VIII.2003, genitalia prep. 2026/\%/ Kovács, 1 \%, legit \& coll. S. $\&$ Z. Kovács. All were attracted to light.

Gelechiinae Stainton, 1854 largely corresponds with those of the earlier classifications, but includes the genera Xystophora and Sophronia. The tribal subdivision is in need of further studies, but currently uses the already established tribes: Gelechiini, Gnorimoschemini and Litini (KARSHOLt et al. 2013: 344-345). In Europe 452 species, in Romania 144 are known and 3 further unnamed species are listed.

Gelechiini Stainton, 1854 comprising also the genera Xystophora and Sophronia, is represented in Europe with 133 species, in Romania 55 are known and one unnamed species is also mentioned.

Xystophora Wocke, 1876 is distributed in the Palaearctic region, with 9 recognized species, and two further are known from India. In Europe 2 are known, recorded also from Romania.

Xystophora carchariella (ZELLER, 1839) is distributed in Europe, the Near East, China and the Russian Far East (Li \& ZHeNG 1998: 107; ElSNER et al. 1999: 24; JUNNILAINEN et al. 2010: 19). In Romania there are only old records from Dobrogea (MANn 1866: 355) and Crişana (Kovács \& Kovács 2001: 90).

Xystophora pulveratella (HERRICH-SCHÄFFER, 1854) is distributed in most of Europe except the northern parts, and southern Siberia (ELSNER et al. 1999: 24; JunNILAINEN et al. 2010: 19). Old data are from Banat (ReBel 1911: 412; KöNIG 1975: 34), Crişana, Muntenia (Bucegi Mountains) (PoPescuGorJ 1995: 176) and Dobrogea (SzéKely \& CERnEA 2007: 131). Another old record by CĂPUŞE \& Kovács (1987: 60, as Caryocolum steudeliellum FREY) was not confirmed during the revision of the L. Diószeghy collection, the specimen proved to be Chionodes fumatella (Douglas, 1850), but three other specimens were identified from Ineu (Crişana) by Kovács \& KovÁcs (2001: 90, 95). Recent published and unpublished data are from the Apuseni Mountains (RÁKosy \& Wieser 2010: 43; legit \& coll. S. \& Z. Kovács), the Eastern Carpahians (Ciuc Mountains, legit \& coll. S. \& Z. Kovács), Muntenia and Dobrogea (legit \& coll. S. \& Z. Kovács). We collected them at light in steppe habitats on limestone and mesophyle meadows at low altitude.

Athrips BILlBerg, 1820 is Holarctic in distribution (HuEMER \& KarSHOLT 1999: 176) with more than 70 recognized species (ADAMSKI \& SATTLER 2019: 23). The Palaearctic species were reviesed recently by BIDZILYA (2005b) recognizing 34 species, since then two more have been described from Russia (JunNILAINEN \& NuPPONEN 2010: 23; BidZILYA \& NuPPONEN 2018: 389). In Europe there are 16 known species, 6 of them recorded also from Romania.

Athrips pruinosella (LIENIG \& ZeLLER, 1846) is distributed in the northern and central parts of the Holarctic region (BIDZILYA 2005b: 54). In Romania recorded only in old publications from Grumăzeşti in Moldova (CARADJA 1901: 151) and the Retezat Mountains (GozMÁNY 1953: 183). Recently specimens were taken from the Eastern Carpathians, Giurgeu Depression (Voşlăbeni, Szenéte, 760 m, collecting data between 10-25.VII, legit \& coll. S. \& Z. Kovács).

Athrips rancidella (HERRICH-SCHÄFFER, 1854) is distributed in the Holarctic region (HUEMER \& KARSHOLT 1999: 176). In Romania old records are from Vatra Dornei and Suceava in Moldova (HormuZaki 1907: 83; Nemeş \& LuNGOCI 1973: 241), Sibiu in Transylvania (CzeKELIUs 1934: 68) and Ineu in Crişana (KovÁcs \& KovÁcs 2001: 96). Recently it was collected from Dobrogea (Canaraua Fetii, Măcin Mountains, Dobrogei Gorge, Hagieni, legit \& coll. S. \& Z. Kovács) and some Transylvanian sites: Viişoara (KovÁcs et al. 2002: 55), Lechinţa, Toldal and Glodeni (legit \& coll. S. \& Z. Kovács) in the Transylvanian Basin, Rimetea in the Apuseni Mountains (RÁKosY \& Wieser 2010: 54) and the Baraolt, Gurghiu, Ciuc and Perşani Mountains in the Eastern Carpathians (legit \& coll. S. \& Z. Kovács). First records for Oltenia and Banat: Oltenia, Schela Cladovei, 100 m, 22.IX.2019, 2 ô, 1 o ; Banat, Dubova, 200-300 m, 23.IX.2019, 1 q, legit \& coll. S. \& Z. Kovács. This appears to be the most frequent and widespread member of the genus in Romania.

Athrips nigricostella (DuPONCHEL, 1842) is distributed in Europe, Turkey, Kazakhstan and Kyrgyzstan. The host-plants are Medicago species (BIDZILYA 2005b: 30). In Romania only old data 
were available from the surroundings of Tulcea in Dobrogea (MANN 1866: 355) and from Mehadia in Banat (REBEL 1911: 412). Recently it was collected in Dobrogea again (Hagieni forest, 12.V.2017, 5 , legit \& coll. S. \& Z. Kovács). The specimens have been attracted to light in a steppe habitat on limestone. The record for Dobrogea was omitted by RÁKOSY \& GoIA (2021: 58).

Athrips mouffetella (LinNAEUs, 1758) is distributed in central and northern Europe and North America (HuEMer \& Karsholt 2010: 180). In Romania is known with old data from Banat (ReBel 1911: 412) and Moldova (PoPESCU-GoRJ \& Nemeş 1965: 157; NEMEŞ \& DĂNILĂ 1970: 185), both old and recent data from Transylvania (Cisteiu de Mureş) (Czekelıus 1918: 45), the Eastern Carpathians (Hăşmaş, Gurghiu, Harghita and Ciuc Mountains, legit \& coll. S. \& Z. Kovács). Data from Livada, Foieni and Mujdeni (ARDELEAN 1998: 169) are doubtful; those from the Retezat Mountains (Kovács \& Kovács 2001: 96) are wrong and refer to $A$. patockai (see below). Usually only single specimens were taken during the day or attracted to light in mountain forest edges at 650-1250 $\mathrm{m}$, where the larval host-plants, the Lonicera species are most abundant.

Athrips patockai (PovolnÝ, 1979) was recorded from Slovakia, Slovenia, Romania, Ukraine and Russia (BIDZILYA 2005b: 64). In Romania it was recorded for the first time from the Eastern Carpathians (Harghita Mountains) based on a single specimen (Kovícs \& KovÁcs 2000: 29). Later four specimens were published from the Southern Carpathians (Cibin Mountains) (BIDZILYA 2005b: 62) and one more from the Apuseni Mountains (Rimetea) (RÁKOSY \& WIESER 2010: 42). During the present study 4 specimens were identified from the Retezat Mountains (1000-1200 m, 8.VI. 1937, 1 ô; 27.VI.1937, genitalia prep. 1206/ㅇ/

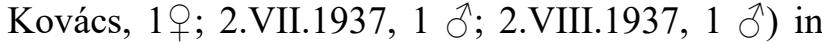
the L. Diószeghy collection which were misidentified and one specimen was published as Scrobipalpa aplasticella REBEL by CĂPUŞE \& KovÁcs (1987: 60) and later as Athrips mouffetella by KovÁcs \& Kovács (2001: 96), the other 3 were found in the unidentified material and published as Carpatolechia notatella (HüBNER, 1813) and A. mouffetella by Kovícs \& KovÁcs (2001: 94, 96). Recently we collected it from the Eastern Carpathians (Harghita, Ciuc and Perşani Mountains), where Spiraea media Fr. Schm. occurs, in the Apuseni Mountains (Rimetea), where Spiraea ulmifolia Scop. occurs (GroZA in RÁKOSY \& WIESER 2010: 14). A female specimen was beaten also from Spiraea salicifolia L. shrubs in the Giurgeu Depression (Borzont). Probably all three mentioned Spiraea species are host-plants of the species. Most of the specimens were taken during the day, but a few attracted to artificial light.
Athrips aquila Junnilainen, 2010 (Figs 34-35) was known only from south-eastern Kazakhstan and the southern part of the Ural Mountains (Russia). The species has already been mentioned by BIDZILYA (2005b: 64), but formally named only by Junnilainen (JUNNILAINEN \& NuPPONEN 2010: 21). First record for the Romanian fauna: Dobrogea, Măcin Mountains, Greci, 250 m, 26.V.2007, genitalia prep. 1775/ふ/

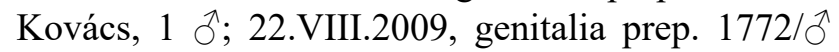
and 1773/O/ Kovács, TLMF Lep 27426, 24 ภ, 1 + , legit S. \& Z. Kovács, coll. TLMF, coll. ZMUC, coll. S. \& Z. Kovács. All were attracted to light. A recently barcoded specimen clustered into the BIN BOLD:ADO3593 to $0.32 \%$ p-distance to a specimen from the southern Ural Mountains (BOLD Systems, accessed 1 December 2020). The male collected in May probably belongs to the first generation, it is larger in size (wingspan $15 \mathrm{~mm}$ ) and appears to be more wide winged than the specimens collected in August,

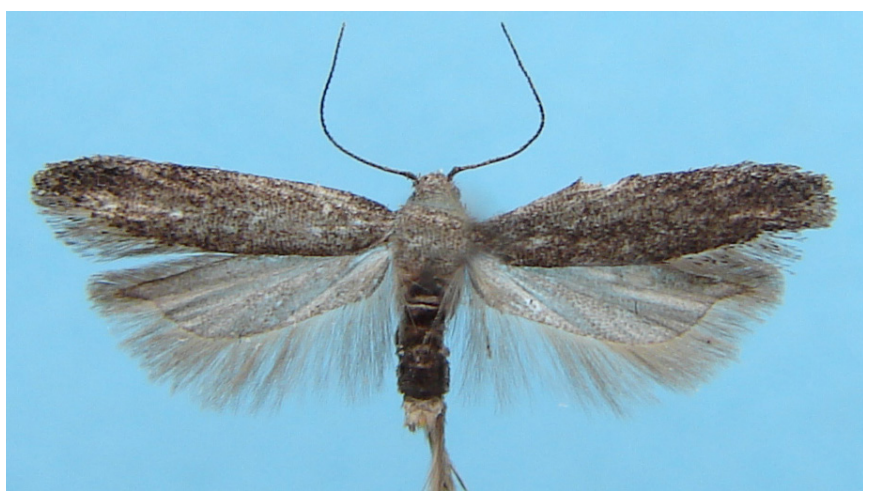

Fig. 34. Athrips aquila JunNILAINEN, 2010: adult, male, wingspan 13.5 mm, Dobrogea, Măcin Mountains, Greci, 250 m, 22.VIII.2009, legit \& coll. S. \& Z. Kovács.

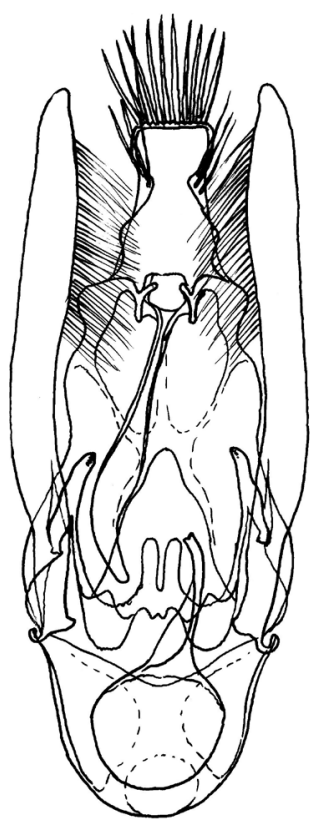

Fig. 35. Athrips aquila JUNNILAINEN, 2010: free floating male genitalia in ventral view, genitalia prep. 1772, same data as Fig. 34. 
which probably represent the second generation, are smaller in size (their alar expansion ranges between $11-12 \mathrm{~mm}$ ) and the forewing appears to be slenderer. In the original description of the species JUNNILAINEN \& NuPPONEN (2010: 23) state that the specimens collected from mid-June to late August represent the first generation and the single specimen collected in September is part of the second generation. In the Măcin Mountains the Spiraea crenata L. shrubs cover large spots in the steppe and forest steppe habitats (Petrescu in Wieser et al. 2000: 89), and must be the host-plant of the species.

Neofriseria SATtLER, 1960 is distributed in the Palaearctic region from western Europe to Mongolia (Huemer \& Karsholt 1999: 168). In Europe 8 species were recorded (HuEMER \& KARSHOLt 2020: 96), from Romania only one is known.

Neofriseria peliella (TReItschKe, 1835) is distributed in the western Palaearctic (HUEMER \& KARSHOLT 1999: 169). In Romania is known from Moldova (CARADJA 1899: 204) and Transylvania (Czekelius 1918: 44). We collected only single specimens in the Eastern Carpathians (Harghita, Bodoc and Gurghiu Mountains) and the Transylvanian Basin (Toldal).

Prolita LERAUT, 1993 is distributed in the Holarctic region (HUEMER \& KARSHOLT 1999: 172) and 22 species are recognized (ADAMSKI \& SATTLER 2019: 24), two of them recorded from both Europe and Romania.

Prolita sexpunctella (FABRICIUS, 1794) is distributed mainly in the mountains of the central and northern parts of the Holarctic region (HUEMER \& KARSHOLT 1999: 173). In Romania it was known from the Southern Carpathians (CzeKelius 1901: 87; Diószeghy 1930a: 285; PopesCu-GorJ 1995: 176). A record from the Turda Gorge in the Apuseni Mountains (RÁKosY 2002: 67) is most probably a misidentification and may refer to the following species. We collected them in the higher regions of the Eastern and Southern Carpathians usually between 1500-2100 m (Călimani, Harghita, Ciucaş, Bucegi, Făgăraş, Parâng, Retezat Mountains), at lower altitudes only in peat bogs (Luci, $1000 \mathrm{~m}$ and Mohoş, $1050 \mathrm{~m}$ in the Harghita Mountains).

Prolita solutella (ZeLLER, 1839) is distributed in the temperate regions of Europe and Turkey (HuEMER \& Karsholt 1999: 174). In Romania it was known only from Moldova (CARADJA 1901: 151), Transylvania (CzeKelius 1909: 162; RÁKosy 2002: 67) and from Valea lui Mihai in Crișana (RothschiLd 1913: 80). One specimen from Romania (Turda Gorge) has been sequenced (HuEmer et al. 2020, supplementary material 2, NJ tree 42 ; BOLD SYSTEMS, accessed 3 December 2020). Contrary to its congener prefers the lower altitudes, it was found in warm sites from lowlands up to $1100 \mathrm{~m}$ in the mountains. We collected the species in the Eastern Carpathians (Baraolt, Perşani, Gurghiu Mountains, Trei Scaune Depression) and Apuseni Mountains (Turda Gorge, Cheia, Râmeț). First record for Dobrogea: Cotu Văii, 25.VIII.2017, 1 §, legit \& coll. S. \& Z. Kovács.

Sophronia HÜBNER, 1825 comprises 24 species distributed in the Palaearctic, Nearctic and Afrotropical regions (ŠUMPICH et al. 2019: 359). Formerly it was placed in the Anacampsinae, currently in Gelechiinae (KARSHOlt et al. 2013: 344). In Europe 12 species were recorded (HuEMER \& KaRsholt 2020: 96), in Romania 6, but $S$. chilonella (TreitschKe, 1833) was deleted from the checklist (see below in the list of the deleted species).

Sophronia semicostella (HÜBNER, 1813) is distributed throughout most of Europe except the northernmost parts (ELSNER et al. 1999: 49). In Europe there are two BINs without clear geographical separation (HuEMER \& KARSHOLt 2020: 130). In Romania it was recorded only from Transylvania (Czekelius 1909: 163; RothsChild 1912a: 29; RÁKosy 2002: 67), Moldova (PoPESCu-GorJ \& NeMEŞ 1965: 158) and the Bucegi Mountains (POPESCU-GoRJ 1995: 176). Recently single specimens were collected from the Transylvanian Basin (Glodeni) and several sites in the Eastern Carpathians (legit \& coll. S. \& Z. Kovács). Material collected in Romania has not yet been genetically examined.

Sophronia illustrella (HÜBNER, 1796) is distributed in southern Europe eastwards of Italy, only locally recorded in central Europe, also known from the Near East (ElSNER et al. 1999: 49). In Romania there are mainly old records of single specimens from Dobrogea (Tulcea, legit \& coll. Mann), Banat (Băile Herculane) (HedemANn 1897: 30; Rebel 1911: 413; SzÉKely \& Cernea 2007: 133), Crişana (Ineu) (Kovács \& Kovács 2001: 97), Moldova (Grumăzeşti, Suceava) (Nemeş \& Lungoci 1973: 241) and Oltenia (RÁKOSY \& Goia 2021: 59). Recently it was collected in Banat from Dubova (legit \& coll. S. \& Z. Kovács).

Sophronia grandii HeRING, 1933 was recently recognized as a senior synonym of $S$. ascalis GOZMÁNy, 1951 (HuEMER \& KARSHOLt 2020: 130). It is distributed in central Europe (ELSNER et al. 1999: 50). In Romania it was recorded only from Ineu (legit L. Diószeghy, coll. Natural History Museum, Vienna) by $\operatorname{KaSY}(1963$, as $S$. ascalis). Later the same data were published again, but referring to the previous publication (KASY 1965: 7) mentioned only Transylvania. Ineu in the present interpretation is located in Crișana. In Rákosy \& Goia (2021: 59, 219, as $S$. ascalis) the record for Transylvania was based 
only on the latter publication (KASY 1965: 7), at that time the first record (KASY 1963) including the locality name Ineu was not available for us, consequently the symbol for Transylvania must be deleted in RÁKOsY \& GoIA (2021: 59). Recently the species was recorded from Ineu again (KovÁcs \& KovÁcs 2000: 35, 2001: 97). First record for Dobrogea: Hagieni forest, 22.VI.2016, 1 ㅇ, legit \& coll. S. \& Z. Kovács.

Sophroniahumerella ([DENIS\&SCHIFFERMÜLLER], $1775)$ is distributed in almost all Europe, North Africa and the Near East (ElsNer et al. 1999: 50). In Romania it was mentioned for the first time from Moldova by CARADJA (1899: 206), later recorded from most of the country except Banat (RÁKOSY \& GoIA 2021: 59). Recently it was collected from the Eastern Carpathians (Perşani, Baraolt, Gurghiu Mountains, Bicaz Gorge), the Transylvanian Basin (Păingeni), Apuseni Mountains (Turda Gorge) and Dobrogea (Măcin Mountains), legit \& coll. S. \& Z. Kovács.

Sophronia sicariellus (ZELLER, 1839) is widespread across Europe (ELSNER et al. 1999: 50). In Romania it was recorded from Banat (HEDEMANN 1897: 30; Rebel 1911: 413), Moldova (CARADJA 1901: 154, 1905: 243; NeMEş \& DĂNILĂ 1970: 183) and Transylvania (Czekelius 1918: 46; RÁkosy \& WIESER 2010: 43). According to our collecting data it is widespread in both dry and mesophile meadows in Transylvania. First record for Dobrogea: Măcin Mountains, Greci, 250 m, 26.V.2007, 1 o, 2 क; 1.VII.2015, 1q; 18.VI.2016, 3 Oे, 1 o, legit \& coll. S. \& Z. Kovács.

Mirificarma GozmÁnY, 1955 is distributed in the Palaearctic region, one species was introduced to North America (HuEMER \& KarSholt 1999: 125, 2001: 48). In Europe 18 species are known, 8 were recorded from Romania, but M. flavella (DUPONCHEL, 1844) was deleted from the checklist (see below in the list of the deleted species).

Mirificarma rhodoptera (MANN, 1866) is known from Greece and from Turkey to Lebanon (HUEMER \& KARSHOLT 1999: 126). It was described based on a single male specimen collected in the surroundings of Tulcea (Dobrogea) by ManN (1866: 353). The holotype is deposited in the Natural History Museum in Vienna (PITKIN 1984: 21). Despite Dobrogea is an intensively studied region of Romania the species has not been seen in that region since, it was mentioned only in checklists (POPESCU-GoRJ 1984: 128; KovÁcs \& Kovács 2000: 28; RÁKosy et al. 2003: 65; RÁKosY \& GoIA 2021: 57).

Mirificarma maculatella (HÜBNER, 1796) is distributed in the southern and central parts of Europe and Turkey (HuEMER \& Karsholt 1999: 130). In Romania there are old records from Transylvania
(Czekelius 1909: 162), Oltenia (RÁkosy \& Goia 2021: 57) and Moldova (Gârboavele forest) (OLARU \& Nemeş 1968: 169) and recent data from Dobrogea (WIESER et al. 2000: 33) and Transylvania (KovÁCs et al. 2002: 55). We collected the species in lowlands and low mountains in the Transylvanian Basin (Toldal, Glodeni, Viişoara), the Apuseni Mountains (Cheia, Scăriţa-Belioara), and in warm sites of the Eastern Carpathians (Baraolt, Perşani, Harghita, Gurghiu, Ciuc Mountains) up to $1200 \mathrm{~m}$ in the Bicaz Gorge. First record for Banat: Dubova, 200-300 m, 17.VI.2021, 2 đૈ, legit \& coll. S. \& Z. Kovács.

\section{Mirificarma eburnella ([DENIS \&} SCHIFFERMÜLLER], 1775) is distributed in Europe except the northern parts, Turkey, the Middle East and North Africa (HuEMER \& KARSHOLt 1999: 130). It is widely distributed in Romania, mentioned from Dobrogea already by MANN (1866: 355), but according to RÁKosY \& GoIA (2021: 57) not yet recorded from Muntenia and Oltenia, however, in the latter region it was mentioned from Cloșani (Gorj County) by CĂPuşe (1964: 18, as formosella (НB.)). Recently collected material was examined from Transylvania and Dobrogea (legit \& coll. S. \& Z. Kovács). In the checklist of Romanian Microlepidoptera (POPESCUGORJ 1984: 128) it was listed twice, as M. eburnella and also with its synonym M. flammella (HüBNER, 1825).

Mirificarma lentiginosella (ZeLLER, 1839) is distributed in western and central Europe and Turkey (Huemer \& Karsholt 1999: 131). In Europe two BINs are known without geographical separation (HUEMER \& Karsholt 2020: 130). In Romania it was recorded only from Moldova (CARADJA 1899: 203) and Transylvania (environs of Cluj) (PoPESCUGORJ 1964: 35). Recently it was collected from low altitudes in the Transylvanian Basin (Viişoara) and warm mountain sites in the Eastern Carpathians (Bicaz Gorge, Baraolt, Perşani Mountains, Giurgeu Depression), Apuseni Mountains (Rimetea) and Banat (Dubova, 200-300 m, 23.IX.2019, 1 o; Băile Herculane, 250 m, 24-25.IX.2019, genitalia prep. 2361/q/Kovács, 1 q), all legit \& coll. S. \& Z. Kovács. It is the first record for Banat. Material collected in Romania has not yet been genetically examined.

Mirificarma cytisella (TREITSCHKE, 1833) is distributed in the southern and central parts of Europe (Huemer \& Karsholt 1999: 132). In Europe the barcoded specimens cluster into four BINs without geographical separation (HUEMER \& KARSHOLT 2020: 130). In Romania it was recorded only from Crişana (RothsCHILD 1913: 80, as Gelechia; Kovícs \& Kovács 2001: 95) and Transylvania (CzeKelius 1918: 44). Recently it was collected from the Transylvanian Basin (Viişoara, Lechinţa), Apuseni Mountains (Ardeu, Rimetea, Râmeţ) and Eastern Carpathians 
(Baraolt, Gurghiu, Ciuc Mountains), legit \& coll. S. $\&$ Z. Kovács. Material collected in Romania has not yet been genetically examined.

Mirificarma interrupta (CURTIS, 1827) is distributed in western and central Europe and North Africa (HUEMER \& KarSHOLT 1999: 134). In Romania it was recorded only from Bârnova (Iaşi) in northeastern Moldova by NEMEŞ \& DĂNILĂ (1970: 184), in RÁkosY \& GoIA (2021: 57) the symbol representing this record is placed erroneously in Muntenia instead of Moldova.

Mirificarma mulinella (ZELLER, 1839) is distributed in western and central Europe and North Africa (HuEMER \& KarSHOLT 1999: 134). In Romania it was recorded only from southern Moldova (Tecuci) by NeMEŞ \& DăNILĂ (1970: 184).

Aroga Busck, 1914 is distributed in the Holarctic region (HUEMER \& KARSHOLT 1999: 156). In Europe 8 species are known (HUEMER \& KARSHOLT 2020: 97), from Romania 3 were recorded, but the presence of $A$. aristotelis (MILLIÈRE, 1876) needs confirmation.

Aroga velocella (ZeLLER, 1839) is widely distributed in Europe and Turkey (HUEMER \& KARSHOLT 1999: 156). It is a genetically variable species, in Europe with three BINs without geographical separation (HUEMER \& KARSHOLT 2020: 130). In Romania it was recorded from Banat (Rebel 1911: 411; BuRnaz 1993: 178), Transylvania (RoTHSCHILD 1912: 29), Crişana (RothSCHILD 1913: 80; Kovács \& KovÁcs 2001: 95), Moldova (NeMEş \& DĂNILĂ 1970: 184) and Dobrogea (WIESER et al. 2000: 33). We collected it in large number in Transylvania and Dobrogea, predominantly in warm and dry low mountain habitats. Material collected in Romania has not yet been genetically examined.

Aroga flavicomella (ZeLLER, 1839) is widely distributed in Europe and Turkey (HuEmer \& KARSHOLT 1999: 156). It is a genetically variable species, with four BINs in Europe without geographical separation (HUEMER \& KARSHOLT 2020: 131). In Romania it was recorded from Moldova (CARAdja 1905: 233), Crișana (Kovács \& Kovács 2001: 95) and Transylvania (RoTHSCHILD 1912a: 29; DiósZEGHY 1930a: 285, 1930b: 22; KovÁCs \& KovÁcs 2001: 95; Kovács et al. 2002: 55; RÁKosY 2002: 67). We collected it only in Transylvania in warm and dry low mountain habitats. First record for Muntenia: Breaza (Buzău County), 3.V.2005, 1 §, legit \& coll. V. Dincă. Material collected in Romania has not yet been genetically examined.

Aroga aristotelis (MiLLIÈRE, 1876) is distributed in southern Europe from Spain to the southern Ural Mountains, Turkey, Israel, the Middle East, Mongolia and central Asia (JunNilainen et al. 2010: 37; BIDZILYA et al. 2019a: 47). In Romania there is an old record from the Retezat Mountains as "Gelechia aplasticella RBL. Br.[anu], 1200 m, 9. Juli, [1929] Diósz." (DiószeGHY 1935: 124). Unfortunately we did not found any Gelechiidae specimen with the above mentioned collecting data neither in the L. Diószeghy collection deposited in the Székely National Museum in Sfântu Gheorghe (Kovács \& Kovícs 2001) nor in the HNHM (Zs. BÁLINT \& G. KaTONA pers. comm.), where the other part of the L. Diószehy collection is deposited. Another record (CĂPUŞE \& Kovács 1987: 60, as Scrobipalpa aplasticella REBEL) refers also to the L. Diószeghy collection (Retezat Mountains, 1100 $\mathrm{m}, 27$.VII.1937), but this specimen re-examined by us proved to be Athrips patockai (Povolný, 1979) (see above). Because we have not been able to locate the voucher specimen to ascertain whether or not it was correctly identified, we consider that its presence in Romania needs confirmation. Gelechia aplasticella REBEL, 1913 is a nomen nudum (GozMÁNy 1958: 223; LepIndex, accessed 31 May 2019; Huemer \& KARSHOLt 2020: 98).

Filatima Busck, 1939 comprises about 100 described species, the majority of them distributed in the Nerctic region, about 20 species in the Palaearctic region and only a few in the Neotropical region (Kovícs \& Kovács 2002a). In Europe 11 species were recorded (HUEMER \& KARSHOLt 2020: 96), in Romania 4 are known.

Filatima spurcella (DUPONCHEL, 1843) is distributed in southern Europe and the southern parts of central Europe, Turkey and Armenia (HuEMER \& KARSHOLT 1999: 163). In Romania old data are known from Azuga in Muntenia (CARAdja 1901: 151), Sibiu in Transylvania (CzeKelius 1905: 82) and in Moldova the Gârboavele forest (Olaru \& NemEş 1969: 128) and Tecuci (Nemeş \& DĂNILĂ 1970: 184). One specimen from the environs of Ciucurova in Dobrogea has been sequenced (HUEMER et al. 2020, supplementary material 2, NJ tree 27; BOLD Systems, accessed 6 December 2020). Recent data are available only from Dobrogean sites: the Măcin Mountains (WIESER et al. 2000: 33; legit \& coll. S. \& Z. Kovács), Lespezi, Dobrogei Gorge and Capidava (legit \& coll. S. \& Z. Kovács). We collected the specimens in daytime beaten from Prunus spinosa L., or attracted to light. The symbol for Banat in RÁkosy \& GoIA (2021: 58) must be deleted, because the species was recorded from Greben by RoTHSCHILD (1912c: 178), which is currently Grebenac in modern Serbia.

Filatima transsilvanella Kovács \& KovÁcs, 2002 was described from a large series collected at light in two nearby sites in Transylvania (Viişoara and Turda Gorge) covered with steppe vegetation (Kovács \& Kovács 2002a). One paratype has also been sequenced 
(HUEMER et al. 2020, supplementary material 2, NJ tree 27). No further Romanian collecting sites became known since then, but the species was recorded from the southern Ural Mountains in Russia (JuNNILAINEN et al. 2010: 38). The biology and the early stages are still unknown. The correct year of the description is 2002 (published 18th March, 2002) and not 2001 as cited on the journal. In The Global Lepidoptera Names Index (LepIndex) (BECCALONI et al. 2003, accessed 26 February 2019) is incorrectly stated that the current valid name of the species is transylvanella, which is a misspelling, as well as transsilvaniella in RÁKOsY (2002: 67). In RÁKosy (2013: 70, as Filatina) it is considered a subspecifically differentiated isolate, an endemic of the Carpathians, although no subspecies was ever described and the species has already been recorded from the southern Ural Mountains (JUNNILAINEN et al. 2010: 38).

Filatima tephritidella (DUPONCHEL, 1844) is known from scattered localities of southern Europe except the Mediterranean, northwards to Poland (Huemer \& Karsholt 1999: 164; O. Karsholt pers. comm.). In Romania it was recorded from the Retezat Mountains (GozmáNY 1953: 183) and recently confirmed from Dobrogea through the courtesy of O. Karsholt from a male specimen collected in Hagieni, legit L. Rákosy, det. O. Karsholt, coll. ZMUC (O. KARSHOLT pers. comm.; Kovács \& Kovács 2000: 29). The symbol for Banat in Rákosy \& GoIA (2021: 58) must be deleted, because the species was recorded from Greben by RoTHSCHILD (1912c: 178), which is currently Grebenac in modern Serbia.

Filatima djakovica ANIKIN \& PISKUNOv, 1996 was described based on a single male specimen from the lower Volga area in southern Russia (Saratovskaya Oblast) (ANIKIN \& Piskunov 1996: 173). The second ever record of the species was published from Romania (KovÁcs \& Kovícs 2000: 29, 2001: 66) based also on a unique male specimen: Ineu (Crişana), 2.VII.1938, genitalia prep. 1274/ふ/ Kovács, legit \& coll. L. Diószeghy. Later it was recorded from other Russian and Ukrainean sites, and the previously unknown female was described by BIDZILYA \& BUDASHKIN (2017: 153-155).

Chionodes HüBNER, 1825 is distributed in the Holarctic and Neotropical regions (HUEMER \& KARSHOlt 1999: 137). The Palaearctic fauna was revised by Huemer \& SATtLer (1995). In Europe currently 23 described species are known, in Romania 9 were recorded, but $C$. nubilella (ZETTERSTEDT, 1839) was deleted from the checklist and $C$. nebulosella (HeinemanN, 1870) is replaced with an undescribed species (see below and in the list of the deleted species).

Chionodes luctuella (HÜBNER, 1793) is a boreo- montane species, recorded from northern Europe, the Alps and Carpathians (Huemer \& Karsholt 1999: 141). DNA barcodes of central European specimens cluster into two separate BINs (HUEMER \& KaRSHOLt 2020: 131). In Romania it was recorded only from the Eastern Carpathians (Bicaz Gorge, Harghita Mountains) (Kovács \& Kovács 1994: 40), later we also caught it in the Ciuc Mountains (Racu). The majority of the specimens were collected on a spruce-forest edge, during the day or attracted to light. Material collected in Romania has not yet been genetically examined.

Chionodes continuella (ZELLER, 1839) is Holarctic in distribution, known only from the northern and central parts of Europe (HUEMER \& KARSHOLT 1999: 146). In Romania recorded from Văratec in Moldova (CARADJA 1899: 203), Comana in Muntenia (CARADJA 1905: 242) and the Retezat Mountains in Transylvania (GozMÁnY 1953: 184), but one of the 3 specimens of the latter (15.VII.1928, legit L. Diószeghy, coll. HNHM in Budapest) currently is identified as $C$. distinctella, the other 2 are untraceable (Zs. BÁLINT \& G. KATONA pers. comm.). We consider the record from Muntenia doubtful. Recent data are not available.

Chionodes distinctella (ZeLLER, 1839) is distributed in Europe, North Africa, Turkey and in southern Asia to Mongolia (Huemer \& Karsholt 1999: 148). In Romania it was recorded from the Călimani Mountains already by PÁvel (1898: 18), currently it is known from most of the country except the southern regions (Oltenia, Banat) (RÁKosy \& GoIA 2021: 57). Data from the Noroieni forest (ARDELEAN 1998: 169) are doubtful. It is widely distributed and common, we collected it in several sites of Transylvania and Dobrogea mainly attracted to light, only rarely in the daytime. Certainly is more widely distributed across the country than currently known.

Chionodes hayreddini KoÇAK, 1986 is distributed in the Alps and Carpathians, but the latter was considered doubtful by Huemer \& Karsholt (1999: 149). In Romania single specimens have been collected from the Southern Carpathians (Retezat and Piatra Craiului Mountains), the Eastern Carpathians (Hăşmaş, Harghita, Perşani Mountains), the Apuseni Mountains (Întregalde Gorge) and Crișana (Băile 1 Mai) (Czekelius 1924: 256; Diószeghy 1930a: 285; Kovács \& Kovács 2000: 28, 2001: 95; SzÉKELY \& Cernea 2007: 132; legit \& coll. S. \& Z. Kovács). Most of the collecting sites are exposed rocky mountain habitats, where the moths were hiding on rocks during the day, but we attracted a specimen to light also in a peat bog, and Băile 1 Mai is a lowland locality. Material collected in Romania has not yet been genetically examined.

Chionodes electella (ZELLER, 1839) is distributed 
in northern and central Europe (HUEMER \& KARSHOLT 1999: 150). In Romania it was recorded only from the Southern and Eastern Carpathians (CzeKelius 1901: 87; Diószeghy 1930a: 285; Popescu-GorJ 1995: 176; Kovács \& Kovícs 2001: 95), the Transylvanian Basin (RothSCHILD 1912a: 29) and the Apuseni Mountains (PoPESCU-GoRJ 1964: 35; RÁKOSY 2002: 67). We collected the species during the day on spruce-forest edges in the Eastern Carpathians (Bicaz Gorge, Harghita, Călimani, Ciuc Mountains) between 1000 and $1300 \mathrm{~m}$, usually only single specimens.

Chionodes sp. (Figs 36-37), a single specimen was recorded from the Eastern Carpathians (Călimani Mountains, Vârful Pietrosul, 1800 m, 15-20.

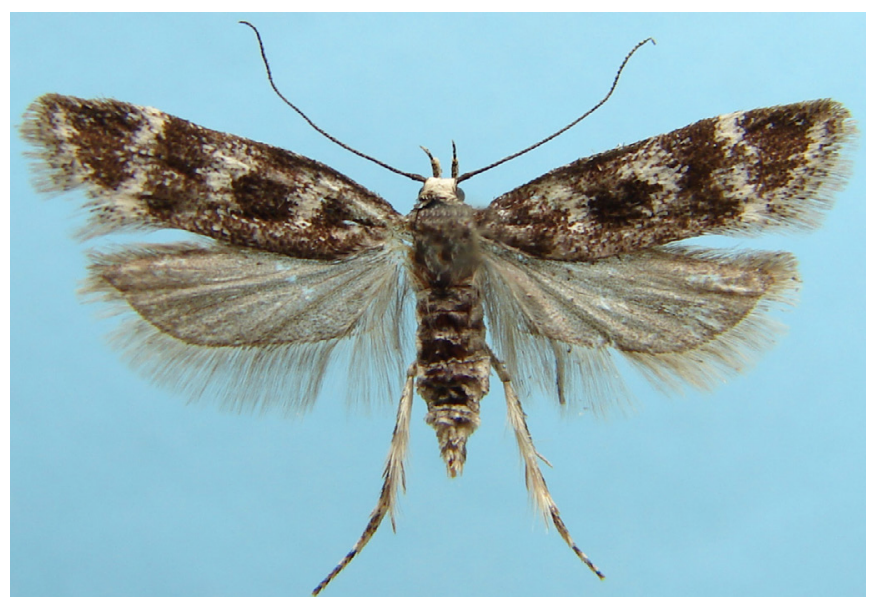

Fig. 36. Chionodes sp.: adult, female, wingspan $19 \mathrm{~mm}$, Southern Carpathians, Piatra Craiului, Vârful Padina Popii, 2000 m, 9.VII.2015, TLMF Lep 28735, legit \& coll. S. \& Z. Kovács.

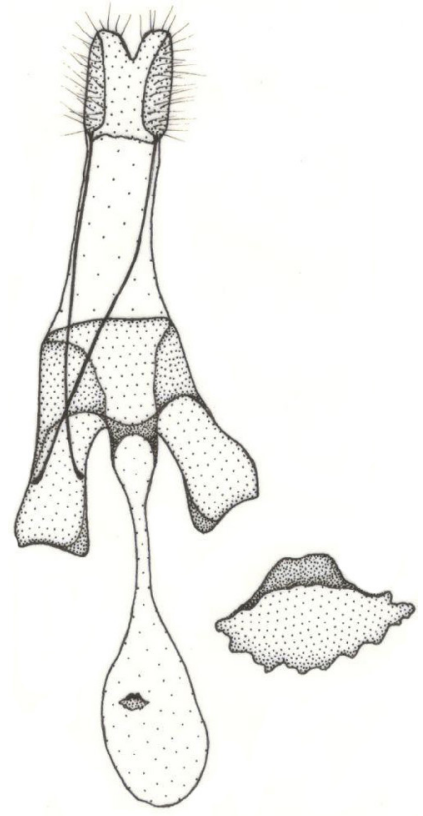

Fig. 37. Chionodes sp.: female genitalia and enlarged signum in ventral view, Eastern Carpathians, Călimani Mountains, Vârful Pietrosul, 1800 m, 15-20.VII.1991, genitalia prep. 902, legit \& coll. S. \& Z. Kovács.
VII.1991, genitalia prep. 902/9/ Kovács, 1 \&, legit \& coll. S. \& Z. Kovács) as C. nebulosella (HeInEMANN, 1870) by KovÁcs \& Kovács (2000: 28). Since then only another female was collected from the Southern Carpathians (Piatra Craiului, Vârful Padina Popii, 2000 m, 9.VII.2015, TLMF Lep 28735, legit \& coll. S. \& Z. Kovács). They were collected during the day. The external appearance of the adult resembles $C$. nebulosella, but the structure of the female genitalia is close to C. viduella (FABRICIUS, 1794). It is an undescribed species, which, considering the lack of the male sex, needs further studies. A recently barcoded specimen clustered to about $2.85 \%$ p-distance from C. nebulosella specimens from Austria, Bulgaria, Germany and Italy (BOLD SySTEMS, accessed 10 February 2021) and confirms our presumption based on differences in morphology.

Chionodes fumatella (Douglas, 1850) is distributed in whole Europe, recorded from Turkey, the Caucasus and Altai Mountains (HuEmer \& KARSHOLT 1999: 154). Barcoded specimens from Europe cluster into three, geographically partially separated BINs (HuEMER \& KARSHOLT 2020: 131). In Romania it was recorded only from Moldova (Vatra Dornei, Suceava, Tișiței Gorge) (HormuZaKI 1907: 83; Nemeş \& Lungoci 1973: 242; RÁKosy et al. 1998: 21), Transylvania (Sibiu, Cluj, Viişoara, Rimetea) (Czekelius 1918: 44; Popescu-Goru 1964: 35; Kovícs et al. 2002: 55; RÁKOSY \& Wieser 2010: 54) and Crişana (KovÁcs \& Kovícs 2001: 95). One sequenced specimen from the Turda Gorge clusters into Chionodes fumatella A (BOLD:AAC7811) (HuEMER et al. 2020, supplementary material 2, NJ tree 21; BOLD Systems, accessed 7 January 2021). Recently it was collected from the Apuseni Mountains (Rimetea), Transylvanian Basin (Glodeni, Toldal) and Eastern Carpathians (Bicaz Gorge, Harghita, Ciuc, Perşani Mountains), legit \& coll. S. \& Z. Kovács.

Chionodes ignorantella (HERRICH-SCHÄFFER, 1854) (Figs 38-39) is distributed in northern and central Europe, to Ukraine in the east (HuEmer \& KARSHOLT 1999: 155). First record for the Romanian fauna: Eastern Carpathians, Trei Scaune Depression, Mestecănişul de la Reci, 540 m, 25.VII.2013, genitalia prep. 1767/ð/ Kovács, 1 ภ, 5 q; 21.VII.2014, 1 ㅇ, legit \& coll. S. \& Z. Kovács. The specimens were attracted to light in swamps with numerous old Alnus glutinosa (L.) Gaertn. trees.

Gelechia HÜBNER, 1825 is distributed in the Holarctic, Neotropical and Afrotropical regions (Huemer \& Karsholt 1999: 106). In Europe 22 species were recorded (Huemer \& Karsholt 2020: 100), in Romania 15 are known.

Gelechia rhombella ([DENIS \& SCHIFFERMÜLLER], $1775)$ is distributed in northern, central and eastern 
Europe (HuEMER \& KARSHOLT 1999: 107). In Romania it was recorded only from Moldova (CARADJA 1899: 203, 1903b: 364; NeMEŞ \& DĂNILĂ 1970: 184), Transylvania (Czekelius 1909: 162; Popescu-GorJ 1964: 34) and Oltenia (RÁKosy \& Gola 2021: 57), but is probably more widely distributed across the country. Data from Porumbești (ARDELEAn 1998: 169) are doubtful. We collected the species in the Eastern Carpathians (Harghita, Ciuc, Perșani Mountains, Bicaz Gorge, Bârsei Depression), where is locally common, Transylvanian Basin (Glodeni) and Apuseni Mountains (Scărița-Belioara).

Gelechia scotinella HERRICH-SCHÄFFER, 1854 is distributed in Europe except the northern parts, and Turkey (HuEMER \& Karsholt 1999: 108). In Romania it was recorded in Transylvania from Sibiu (Czekelius 1898: 73) and Braşov (SzÉKelY \& CERNEA 2007: 132), in Banat from Orşova (NemEş 1972a: 206), in

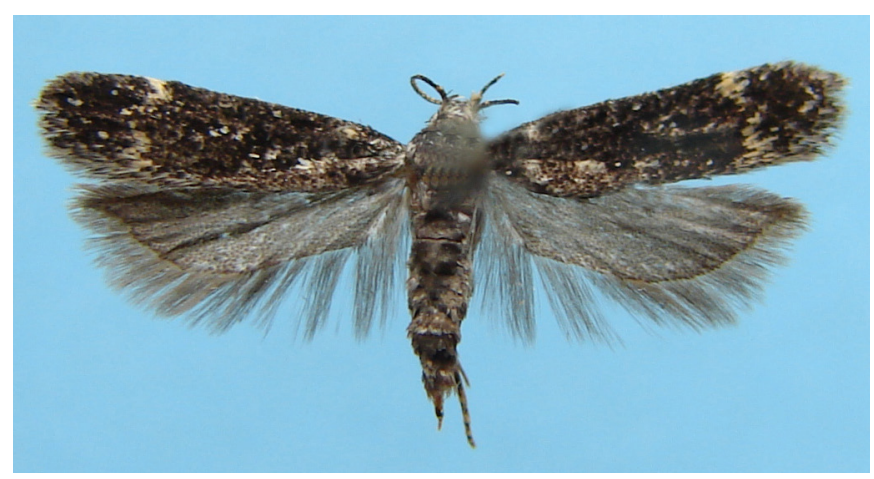

Fig. 38. Chionodes ignorantella (HERRICH-SCHÄFFER, 1854): adult, female, wingspan $13.5 \mathrm{~mm}$, Eastern Carpathians, Trei Scaune Depression, Mestecănişul de la Reci, 540 m, 25.VII.2013, legit \& coll. S. \& Z. Kovács.

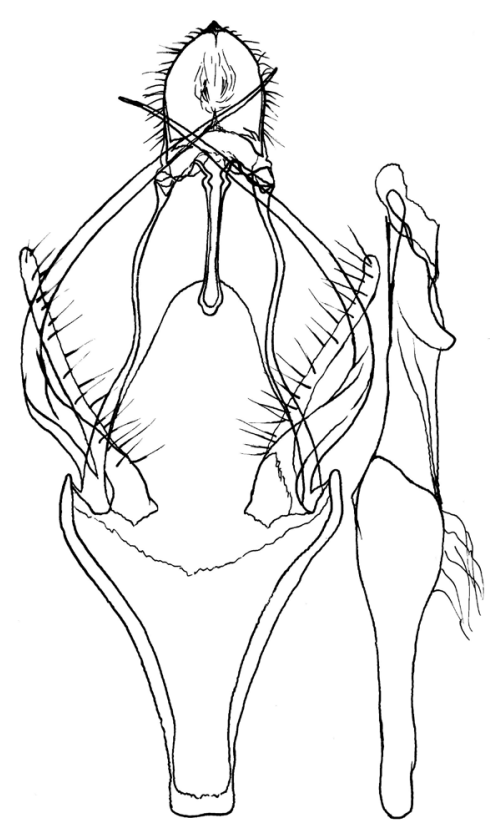

Fig. 39. Chionodes ignorantella (HERRICH-SCHÄFFER, 1854): free floating male genitalia in ventral view, genitalia prep. 1767, same data as Fig. 38.
Crișana from Ineu (Kovács \& KovÁCs 2001: 94) and in Dobrogea from Babadag (PoPESCU-GorJ 1985a: 113) and the Măcin Mountains (WIESER et al. 2000: 33). In Europe three BINs are known, one specimen from the Turda Gorge clustered into Gelechia scotinella A (BOLD:ACQ9801) together with specimens from North Macedonia and Sweden (HuEmER et al. 2020, supplementary material 2, NJ tree 28; BOLD SySTEMS, accessed 7 January 2021). Recent material was collected in the Transylvanian Basin (Toldal, Glodeni), Eastern Carpathians (Baraolt, Perșani, Ciuc, Gurghiu Mountains, Ciuc Depression) and Dobrogea (Măcin Mountains, Canaraua Fetii, Hagieni forest), legit \& coll. S. \& Z. Kovács. They were attracted to light.

Gelechia senticetella (STAUDINGER, 1859) (Figs $40-41$ ) is widely distributed in scattered localities

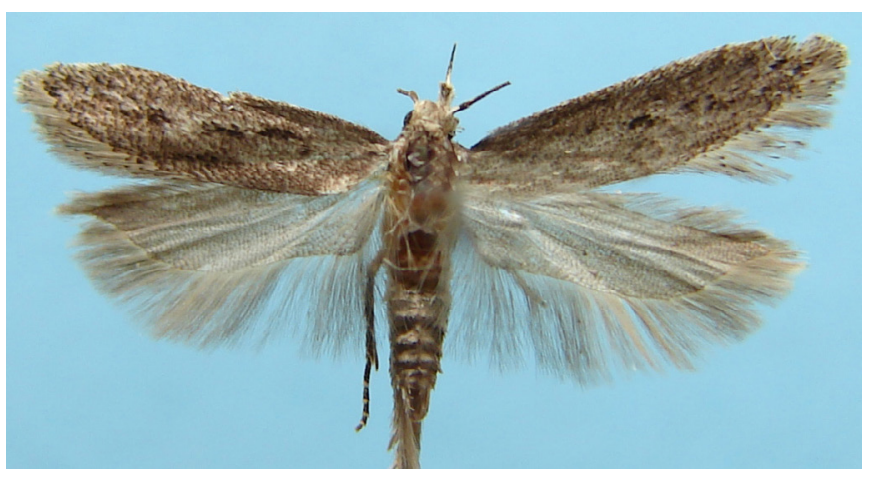

Fig. 40. Gelechia senticetella (STAUDINGER, 1859): adult, male, wingspan 14 mm, Apuseni Mountains, Gilău Mountains, Scăriţa-Belioara, 900 m, 17.VII.2015, legit \& coll. S. \& Z. Kovács.

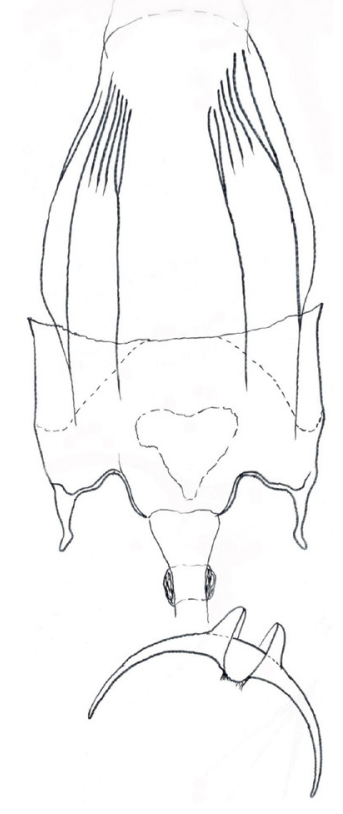

Fig. 41. Gelechia senticetella (STAUDINGER, 1859): segment VIII, posterior part of ductus bursae (above) and signum (below) of the female genitalia in ventral view, Eastern Carpathians, Bicaz Gorge, 1200 m, 4.VII.2012, genitalia prep. 1761 , legit \& coll. S. \& Z. Kovács. 
from Great Britain, France and Germany through Italy, Austria, Slovakia and Hungary to Denmark. The similar G. obscuripennis (FrEY, 1880) was recently reinstated to full species rank following genetic studies and is distributed in scattered localities from Italy and Austria through North Makedonia to Ukraine (ElSNER et al. 1999: 35; HuEMER \& Karsholt 1999: 109; AARVIK et al. 2017: 76; Huemer 2019: 91). First record for the Romanian fauna: Eastern Carpathians, Bicaz Gorge, 1200 m, 4.VII.2012, genitalia prep. 1760/ठ̂ and 1761/O/ Kovács, 3 Ô, 1 O; Apuseni Mountains, Gilău Mountains, Scăriţa-Belioara, 900

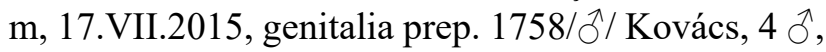
3 , , legit \& coll. S. \& Z. Kovács. All were attracted to light. Material collected in Romania has not yet been genetically examined.

Gelechia sabinellus (ZELLER, 1839) is distributed in most of Europe except the northernmost parts, and Turkey (Huemer \& Karsholt 1999: 110). In Romania it was recorded only from the Eastern Carpathians (Bicaz Gorge, Harghita Mountains) (Kovács \& Kovács 1994: 40, 2000: 27). The record from the Baraolt Mountains (Lempeș Hill) (Albu \& Albu 2018: 20) is a misidentification and refers to Chionodes distinctella (ZELLER, 1839). A single other collecting site was found later: Apuseni Mountains, Gilău Mountains, Scăriţa-Belioara, 900 m, 17.IX.2015, 1 q, legit \& coll. S. \& Z. Kovács.

Gelechia sororculella (HÜBNER, 1817) is distributed in central and northern Europe, and south-eastern Siberia (HUEMER \& KARSHOLT 1999: 111). In Romania it was recorded from Transylvania (Czekelius 1901: 87) and the Bucegi Mountains (Popescu-GorJ 1995: 176). Recently single specimens were collected from scattered localities in the Eastern Carpathians (Bodoc, Harghita, Baraolt Mountains, Giurgeului Depression), legit \& coll. S. \& Z. Kovács.

Gelechia muscosella ZELLER, 1839 is widely distributed in Europe (HuEMER \& KarSHOLt 1999: 113). In Romania it was recorded for the first time from Transylvania (Sibiu) (CzEKELIUs 1898: 73), later from most of the country except Banat and Oltenia (RÁkosy \& Goia 2021: 57). Data from Turulung (ARDELEAN 1998: 169) are doubtful. It is common in the mountains between 600 and $1000 \mathrm{~m}$, where we collected it in large number. Adults rest during the day on the trunks of old Salix caprea L. and Populus tremula $\mathrm{L}$. trees, and can easily be disturbed from there. At lower altitudes the host-plants must be other Salix and Populus species.

Gelechia cuneatella DougLAS, 1852 is distributed in the central and northern parts of the Palaearctic region, extending eastwards to Japan (HUEMER \& KARSHOLT 1999: 113). In Romania it was recorded only from the Eastern Carpathians, for the first time from Vatra Dornei by HoRMUZaKi (1907: 82), later from the Rarău (PeIU \& Nemeş 1970: 60) and Harghita Mountains (Kovács \& KovÁcs 2000: 27). Additionally it was collected from the Baraolt and Ciuc Mountains (legit \& coll. S. \& Z. Kovács). It seems to be a rare species in Romania.

Gelechia asinella (HüBNER, 1796) is a very local species in Europe, ranging from France to Russia. It is known to hibernate as an adult. Larvae feed on narrow-leaved Salix species (HuEMER \& KarSHOLT 1999: 115). In Romania only very old records are from Grumăzeşti (Moldova), Azuga (Muntenia) (CARAdJA 1902: 617) and Mehadia (Banat) (ABAFIAigner 1904: 193; GozMÁNY 1958: 219). Recent data are not available. The record for Muntenia was omitted by Rákosy \& GoIa $(2021: 57,216)$.

Gelechia hippophaella (SCHRANK, 1802) is distributed throughout central and northern Europe, Turkey and eastern Siberia (HuEMER \& KarShOLT 1999: 116). In Romania it was recorded from the Bucegi Mountains (PoPesCu-GoRJ 1995: 176) and Braşov (Postăvarul) (SzÉKely \& CERNEA 2007: 132) and according to RÁkosy \& GoIA (2021: 57) also from Dobrogea. Recently it was collected from the Transylvanian Basin (Lechinţa, Toldal), legit \& coll. S. \& Z. Kovács. It is rare in Romania.

Gelechia basipunctella HERRICH-SCHÄFFER, 1854 is local in Europe ranging from France to Russia, and Turkey (Huemer \& Karsholt 1999: 116). In Romania only old records are from Moldova (Tecuci, Drăgăneşti) (NEMEş \& DăNILĂ 1970: 184). The moth can be expected to occur also in other localities.

Gelechia nigra (HAWORTH, 1828) is widespread across most of Europe except the southernmost and northernmost parts (HUEMER \& KARSHOLT 1999: 117). In Romania it was recorded from Moldova (CARADJA 1899: 203), in the Transylvanian Basin from Şincai (RothsChild 1912a: 29) and Cluj (Popescu-GorJ 1964: 34), the Apuseni Mountains (Turda Gorge) (RÁKosy 2002: 67), the Bucegi Mountains (PoPESCUGORJ 1995: 176) and Băile Herculane (PoPESCUGoRJ 1985a: 113). Recently single specimens were collected in the Transylvanian Basin (Lechinţa) and the Eastern Carpathians (Harghita, Ciuc Mountains), legit \& coll. S. \& Z. Kovács. During the day the adults rest on the trunks of old Populus tremula L. trees and can easily be disturbed from there.

Gelechia turpella ([DENIS \& SCHIFFERMÜLLER], $1775)$ is widely distributed in the Palaearctic region (Huemer \& Karsholt 1999: 118). In Romania is also widely distributed, it was recorded from Transylvania already by RoTHSCHILD (1912: 28), later from the most of the country except Oltenia and Muntenia 
(RÁKosy \& GoiA 2021: 57). It is frequent in riverine forests and poplar-lined roadsides, larvae pupate in the crevices of the bark of the poplars, in daytime adults rest on the trunks and can easily be disturbed from there. They can also be attracted to light.

Gelechia rhombelliformis STAUDINGER, 1871 is distributed from central Europe to central Asia (Huemer \& Karsholt 1999: 119). In Romania there are two old records from Moldova (Grumăzeşti) (CARAdja 1901: 150) and Transylvania (Cisteiu de Mureş, 17.VII.1917, legit R. Gross) (CzeKelius 1918: 44). Recent data are not available.

Gelechia sestertiella Herrich-Schäffer, 1854 is distributed from central Europe to western Russia (Huemer \& Karsholt 1999: 120). In Romania it was recorded from Braşov (CzeKelius 1918: 45), Cluj (Popescu-Gorj 1964: 34), Babadag, Bucureşti (POPESCu-GorJ 1985a: 113) and the Măcin Mountains (WIESER et al. 2000: 33). Recently only single specimens were attracted to light in the Eastern Carpathians (Perşani, Gurghiu Mountains), legit \& coll. S. \& Z. Kovács.

Gelechia dujardini HUEMER, 1991 (Fig. 42) is distributed throughout southern Europe and in Turkey (Huemer \& Karsholt 1999: 122). First record for the Romanian fauna: Banat, Dubova, 200-300 m, 23.IX.2019, genitalia prep. 2452/q/ Kovács, 2 , legit \& coll. S. \& Z. Kovács. The two worn specimens were attracted to light, their identification was possible only with the study of the genitalia.

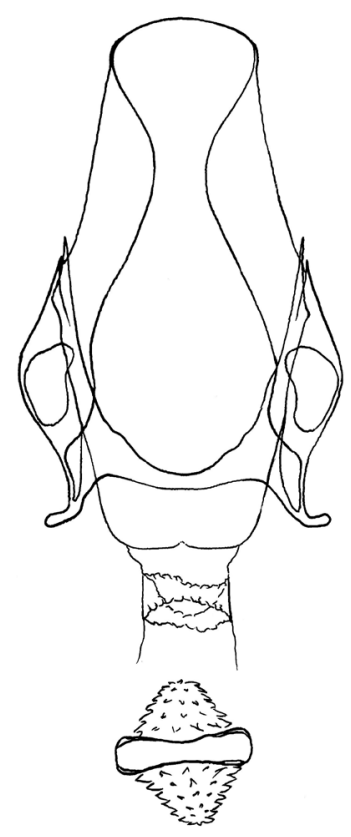

Fig. 42. Gelechia dujardini HuEMER, 1991: segment VIII, posterior part of ductus bursae and signum of the female genitalia in ventral view, Banat, Dubova, 200-300 m, 23.IX.2019, genitalia prep. 2452, legit \& coll. S. \& Z. Kovács.
Psoricoptera Stainton, 1854 is distributed in the Palaearctic region (Huemer \& Karsholt 1999: 122). In Europe two species are known, both recorded from Romania.

Psoricoptera gibbosella (ZELLER, 1839) is distributed in the entire Palaearctic region (HuEMER \& KARSHOLT 1999: 124). Despite is probably widely distributed in Romania it was recorded only from Transylvania (CzeKelius 1918: 44), Crişana (Kovícs \& Kovács 2001: 95), Oltenia (STĂNoIU \& CHIMIŞLIU 1993: 43) and Dobrogea (WIESER et al. 2000: 33). Recently only single specimens were collected from Transylvania (Baraolt, Gurghiu and Apuseni Mountains), and it is frequent in the Măcin Mountains in Dobrogea (legit \& coll. S. \& Z. Kovács).

Psoricoptera speciosella TeICH, 1893 is distributed throughout the northern part of the Palaearctic region, southernmost in northern Italy and France, and extending eastwards to Japan (HUEMER \& KARSHOLT 1999: 124). In Romania it was recorded only from the Eastern Carpathians (Harghita Mountains) by Kovács \& KovÁcs (2000: 27). Later in the same region it was collected from the Perşani and Baraolt Mountains, in the Apuseni Mountains from Scărița-Belioara and in the Transylvanian Basin from Glodeni, legit \& coll. S. \& Z. Kovács.

Holcophora StaUdinger, 1871 is distributed in the Palaearctic and Afrotropical regions, nine species are recognized, four of them recorded from Europe. The systematic position of the genus within the Gelechiidae is still uncertain. It was recently revised by BiDziLYA et al. (2021: 209). In Romania only one species is known.

Holcophora statices STAUDINGER, 1871 is recorded from scattered localities across the Palaearctic region from France, Hungary and Romania through Ukraine and southern part of European Russia to western Kazakhstan, Iran and western China (BIDZILYA et al. 2021: 220). In Romania it was mentioned without further specification by ELSNER et al. (1999: 55), from Banat (legit \& coll. H. Neumann) and Dobrogea (legit \& coll. S. \& Z. Kovács) (RÁkosy \& Goia 2021: 61, 221). We collected the species in Dobrogea (Grindul Chituc, Cetatea Histria, Sarichioi), attracted to light, often in large number, in halophytic habitats of the Black Sea coastal zone.

Gnorimoschemini PovolnÝ, 1964 comprises worldwide 44 genera and about 900 species, it is most diverse in the Palaearctic region with more then 300 species in 21 genera (BIDZILYA et al. 2019b: 106). The European representatives of the tribe were recently revised by HUEMER \& KARSHOLT (2010), recognizing 211 species. Later 240 were listed by HuEMER \& KARSHOLt (2020: 70), but since then additional species 
were described and currently 246 species are known. In Romania 57 species are known, two as yet unnamed species are also mentioned. Ochrodia subdiminutella (Stainton, 1867) was deleted from the checklist (see below in the list of the deleted species).

Gnorimoschema BUSCK, 1900 is distributed in the Holarctic region, with most of the species in the Nearctic region (PovolnÝ 2002: 22), from the Palaearctic region 29 species are described, in Europe 15 are known (BIDZILYA et al. 2019b), and only one of them was recorded from Romania.

Gnorimoschema herbichii (NowICKI, 1864) is Holarctic in distribution, recorded in scattered localities (HuEMER \& KarSHOLt 2010: 37). Currently only northern European specimens were barcoded and they cluster into two BINs (HUEMER \& KARSHOLT 2020: 130). In Romania there are three old records from Transylvania (Cisteiu de Mureş) (Czekelius 1924: 256), Crişana (Ineu) (Kovács \& Kovács 2000: 29, 2001: 96) and northern Moldova (Zvoriştea) (Nemeş 1972b: 183). The moth can be expected to occur also in other localities.

Scrobipalpopsis PovOLNÝ, 1967 as currently known, is distributed in the Holarctic and Neotropical regions. In the Palaearctic region only one species is known (HuEMER \& KaRSHOLt 2010: 54), which was recorded also from Romania.

Scrobipalpopsis petasitis (PFAFFENZELLER, 1867), an arctic-alpine species, it was recorded in Romania only from the Eastern Carpathians (Kovícs \& Kovícs 2000: 29). Despite a specimen having been figured from Romania, the Carpathians are not included in the area of distribution of the species in Europe by HUEMER \& KARSHOLT (2010: 56, colour plate 2 fig. 13). Near the riverine systems on calcareous soil (Bicaz Gorge), specified as preferred habitat by Huemer \& Karsholt (op. cit.) we found it also in a peat bog (Luci).

Scrobipalpa JANSE, 1951 is worldwide in distribution, with more than 300 described species (ADAMSKi \& SATTLER 2019: 24), the greatest species richness (about $87 \%$ ) is in the Palaearctic region (Huemer \& Karsholt 2010: 57). In Europe it is the most species rich genus within Gelechiidae, comprising 112 described species and according to recent genetic studies requires further reassessment (Huemer \& Karsholt 2020: 102, 131). In Romania 21 species are currently known, 6 of them are recorded herewith for the first time. Further, 5 earlier recorded species, S. feralella (ZELLER, 1872), S. suaedella (Richardson, 1893), S. stangei (HERING, 1889), S. costella (HumphreYs \& WeSTWOOd, 1845) and Scrobipalpa salinella (ZELLER, 1847) were misidentifications and are deleted from the checklist (see below in the list of the deleted species). The genus was treated as Scrobipalpa (Euscrobipalpa) in the earlier Romanian checklists (POPESCU-GORJ 1984: 128; Kovács \& Kovács 2000: 18; RÁKosY et al. 2003: 66).

Scrobipalpa acuminatella (SIRCOM, 1850) is one of the most common species of the genus. Its hostplants are various Asteraceae, mainly Cirsium species. It is widely distributed in Europe, recorded also from western and central Asia, Siberia and eastern China (Huemer \& Karsholt 2010: 62). In Romania it was recorded from Moldova (CARADJA 1901: 151), Crişana (Kovács \& Kovács 2001: 96), Transylvania (Czekelius 1918: 44) and Oltenia (RÁKosy \& GoiA 2021: 58). First record for Muntenia: Southern Carpatians, Bucegi Mountains, Caraiman, $2200 \mathrm{~m}$, 27.VI.2003, 19; Jepii valley, $1800 \mathrm{~m}, 11$. VIII.2005, genitalia prep. 2463/ð / Kovács, 1 ठૈ; 9.VII.2013, genitalia prep. 2443/ð / Kovács, 7 ภ, 2 ๆ, legit \& coll. S. \& Z. Kovács. Inhabits various biotopes, we found it in two generations from $600-2200 \mathrm{~m}$ in the Carpathians.

Scrobipalpa hungariae (STAUDINGER, 1871) was recorded only from a few localities in Hungary, Austria, Croatia and Ukraine (HuEMER \& KARSHOLT 2010: 65). In Romania it was mentioned by RákosY \& Wieser (2010: 42) from the Apuseni Mountains (Rimetea) based on a single specimen. Our data are from the same region: Apuseni Mountains, Trascău Mountains, Piatra Secuilor (Rimetea), 6.V.2000, genitalia prep. 1340/ð and 1339/O/ Kovács, 4 Ô, 3 o ; 5.VII.2000, genitalia prep. 1971/P/ and 2441/q/ Kovács, 2 Oૈ, 8 ๆ; 31.III.2017, 1 ○ે; Apuseni Mountains, Gilău Mountains, Scăriţa-Belioara, 900 m, 17.VII.2015, 1 क; 1.IV.2017, 3 ô, legit \& coll. S. \& Z. Kovács. All these specimens were collected at light in xerothermic mountain meadows. The type locality of the species, the environs of Budapest („Ofen”) in Hungary (STAUDINGER 1871: 300-301) is similar, a low mountain area of limestone substrate and covered with a mosaic of steppe vegetation and thermophilous oak forests. The Vértes Mountains, another collecting site in Hungary, are also low mountains of midTriassic dolomite and limestone substrate, covered by similar vegetation (PASTORÁLIS \& SzEŐKE 2018: 5, 21). However, Huemer \& Karsholt (2010: 65) mention swamps and wet meadows as preferred habitats. Their assertion is misleading and most probably incorrect, because SATTLER (1986: 445), their cited source, does not mention any kind of habitat or biotope when dealing with the biology and the distribution of the species. The collecting sites mentioned by the latter, Illmitz and "Zitzmannsdorfer Wiesen", both in the Lake Neusiedl area, are surrounded not only by swamps and wet meadows but also by hills covered with pannonian steppe vegetation (e.g. Hackelsberg, Jungerberg, etc.) and the moths may well originate from there. 
Scrobipalpa brahmiella (HEYDEN, 1862) is a characteristic member of the steppe habitats, confined to Jurinea species and distributed in scattered localities from Belgium to the European Russia (HuEmer \& Karsholt 2010: 67). In Romania it was mentioned only from Viişoara in the Transylvanian Basin (KovÁcs \& Kovács 2000: 29; Kovícs et al. 2002: 55). A nearby locality, Lechința (13.IV.2002, 1 O, legit \& coll. S. \& Z. Kovács) is the single new collecting site discovered since then.

\section{Scrobipalpa chrysanthemella (HOFMANN,} 1867) is confined to Leucanthemum vulgare Lam., distributed in the whole Europe, but recorded only from scattered localities (HUEMER \& KARSHOLT 2010: 75). In Romania it was mentioned only from Dobrogea (Canaraua Fetii) by KovÁcs \& KovÁcs (2000: 29), which re-examined during this study proved to be $S$. proclivella (Fuchs, 1886) (see below). At this time we examined a single male collected in the Eastern Carpathians (Harghita Mountains, Băile Jigodin, 650 m, 30.V.2001, genitalia prep. 1784/ふ/ Kovács, 1 Љ, legit \& coll. S. \& Z. Kovács). It is the first record for Transylvania, the symbol for Dobrogea must be deleted from RÁkosy \& GoIA (2021: 58).

Scrobipalpa proclivella (FUCHS, 1886) is recorded from Europe and Transbaikal in Asian Russia (HuEMER \& Karsholt 2010: 76). In Romania there are only a few old data from Transylvania (Czekelius 1918: 44) and Crişana (KovÁcs \& Kovács 2001: 96), recently taken from the Eastern Carpathians (Racu, Vrabia) and the Transylvanian Basin (Glodeni), legit \& coll. S. \& Z. Kovács. A specimen from Dobrogea (Canaraua Fetii, 13-14.IV.1994, genitalia prep. 958/ठૈ/ Kovács, 1 đิ, legit \& coll. S. \& Z. Kovács) published as $S$. chrysanthemella (Hofmann, 1867) by Kovács \& Kovács (2000: 29) was re-examined during this study and proved to be $S$. proclivella, being the first record for Dobrogea. Another examined specimen from Breaza (Buzău County, 12.VII.2004, 1 ઈ, legit \& coll. V. Dincă) is the first record for Muntenia.

\section{Scrobipalpa obsoletella (FISCHER VON} RÖSLERSTAMM, 1841) is common and widespread, inhabits warm ruderal herb communities and halophytic sites all over Europe, the Near East and vast territories of Asian Russia, larvae feed on Chenopodiaceae (HUEMER \& KARSHOLT 2010: 88). In Romania it was mentioned for the first time from Dobrogea by MANN (1866: 353), other old records are from Moldova (Vatra Dornei) (PeIU \& Nemeş 1970: 60) and Crişana (Ineu) (Kovács \& KovÁcs 2001: 96). The symbol for Transylvania in RÁKosy et al. (2003: 66) and RÁkosy \& Goia (2021: 58) refers to our data, which are published hereunder. First record for Muntenia: Breaza (Buzău County), 29.IV.2003, 1 đૈ, legit \& coll. V. Dincă; Balta Albă, 3.V.2018, genitalia prep. 1973/\&/ Kovács, 1 +; Mihai Bravu, 4.V.2018, genitalia prep. 1977/\&/ Kovács, 2 Ô, 1 q, legit \& coll. S. \& Z. Kovács. Recently it was collected from several sites in Dobrogea and Transylvania (Lechința, Mureș County, 31.V.1996, genitalia prep. 1160/ㅇ/ Kovács, 1 †), legit \& coll. S. \& Z. Kovács.

Scrobipalpa acuta PovolnÝ, 2001 is a poorly known species distributed in Ukraine and the southern Ural Mountains in Russia (HuEMER \& KARSHOLt 2010: 96). First record for the Romanian fauna: Dobrogea, Hagieni forest, 26.VII.2006, genitalia prep. 1820/ $/$ Kovács, 1 ô, legit \& coll. S. \& Z. Kovács, det. O. Karsholt. It seems to be a characteristic species of the East European steppes, this record of great zoogeographical importance represents the southwestern limit of the range of the species.

Scrobipalpa murinella (DUPONCHEL, 1843) is a boreo-montane species, distributed in the Alps, Carpathians, and throughout northern Europe extending eastwards to Siberia (HUEMER \& KARSHOLT 2010: 100). In Romania it was recorded from the Făgăraş Mountains, Catiave, 2200 m, 8.VIII.1910, legit D. Czekelius (Czekelius 1918: 44, as Gelechia cacuminum FreY). Another record from low altitude localities in Suceava County (Nemeş \& LungocI 1973: 241) does not corresponds to the ecological needs of $S$. murinella, and may refer to Scrobipalpula diffluella (FrEY, 1870). The confusion between the two species is possible because for a long period Gelechia cacuminum (FrEY, 1870) was treated as a junior synonym of $S$. murinella (for more details see HUEMER \& KARSHOLT 2010: 200), but currently it is a junior synonym of $S$. diffluella, the synonymy has been established by HUEMER \& KARSHOLT (1998: 55-60). The symbol for Moldova must be deleted in Rákosy \& GoiA (2021: 58). Recent data are not available.

Scrobipalpa pauperella (HEINEMANN, 1870) is distributed in the northern and central parts of Europe from northern Spain to Russia, recorded also from China (Huemer \& Karsholt 2010: 104). The taxon was not mentioned from the Palaearctic region by PovolnÝ (2002), only klimeschi PovolnÝ, 1967 was, which currently is considered a junior synonym of pauperella. In Romania it was mentioned for the first time from the Eastern and Southern Carpathians (Perşani and Bucegi Mountains) by Kovícs \& Kovács (2000: 31), later from the Transylvanian Basin (Sânmarghita) by VICOL (2005, as klimeschi). Further collections are from the Eastern Carpathians (Gurghiu, Ciuc Mountains, Ciuc Depression), the Transylvanian Basin (Viișoara) and Dobrogea (Măcin Mountains, Pricopan Peak, 3-4.VIII.1994, genitalia prep. 1172/q/ Kovács, 1 q), legit \& coll. S. \& Z. Kovács. It is the first record for Dobrogea. Despite its synonymy with $S$. pauperella (HeINEMANN, 1870) having been discussed by Kovács \& Kovács (2000: 
31) S. klimeschi was re-introduced in the Romanian checklist as a different valid species by Rákosy \& GoIA (2007: 73) based on Vicol's data, but mentioned correctly again in the most recent Romanian checklist (RÁkosy \& Goia 2021: 58). According to Huemer \& Karsholt (2010: 104) inhabits meadows and pastures at low altitudes, but we collected it in the Bucegi Mountains up to $1800 \mathrm{~m}$.

Scrobipalpa selectella (CARADJA, 1920) (Figs 43-44) is distributed from China and Mongolia through southern Russia and Ukraine, Turkey to Greece, Tunisia (Huemer \& Karsholt 2010: 119) and Albania (F. Graf in LePIFORUM, accessed 28 February 2019). The taxon was not mentioned from the Palaearctic region by PovolnÝ (2002), but its synonym S. fraterna PovolNÝ, 1969, although the

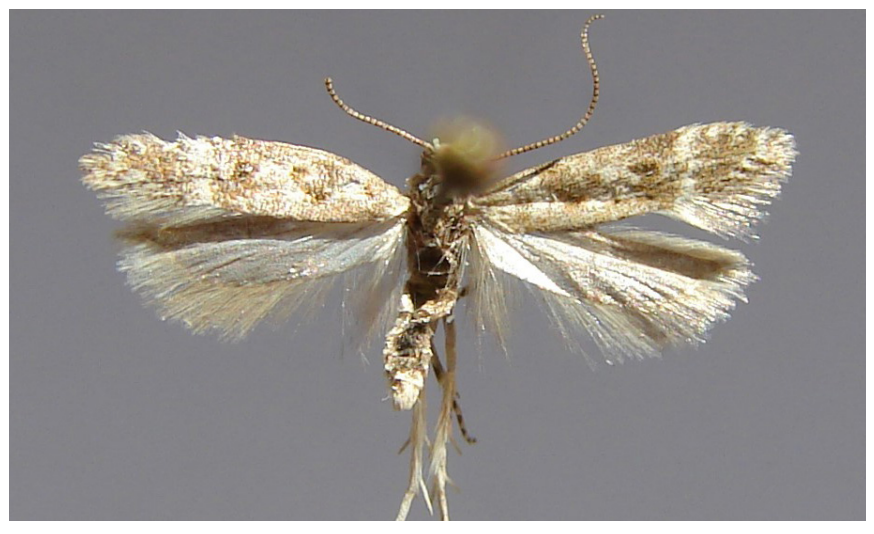

Fig. 43. Scrobipalpa selectella (CARADJA, 1920): adult, male, wingspan $11 \mathrm{~mm}$, Dobrogea, Grindul Chituc, Periboina, 15.VIII.2019, legit \& coll. S. \& Z. Kovács.

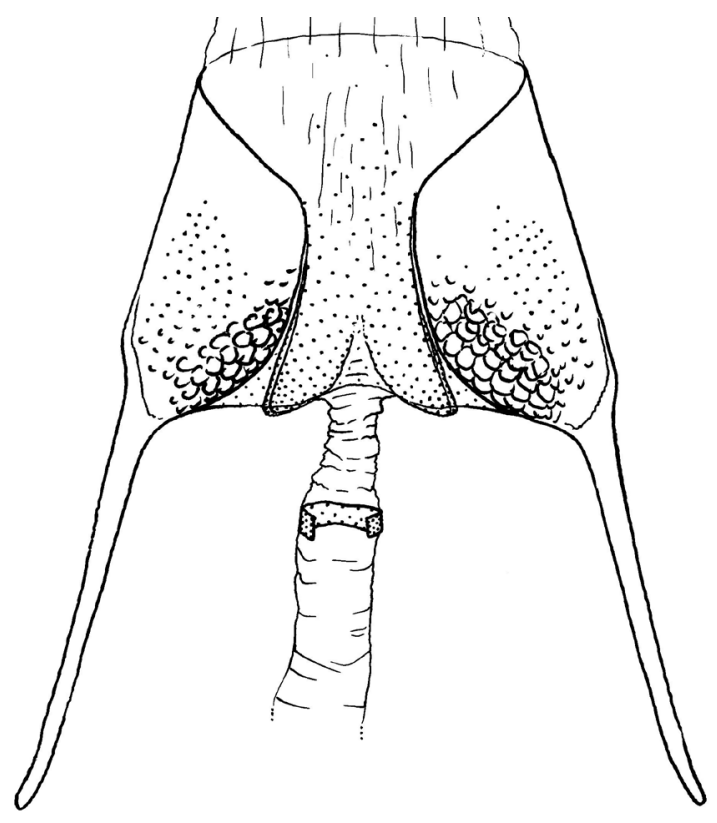

Fig. 44. Scrobipalpa selectella (CARADJA, 1920): segment VIII and posterior part of ductus bursae of the female genitalia in ventral view, Dobrogea, Cetatea Histria, 27.VII.2006, genitalia prep. 2385, legit \& coll. S. \& Z. Kovács. synonymy was established only later by HuEMER \& KARSHOLT (2010: 118). First record for the Romanian fauna: Dobrogea, Cetatea Histria, 11.VIII.2001, 1 ô; 27.VII.2006, genitalia prep. 2385/ㅇ/ Kovács, 1 ; 20.VII.2011, 1 क; Jurilovca, Capul Doloşman, 20.VIII.2009, genitalia prep. 1802/ठै, 2384/ $\widehat{\partial}$ and

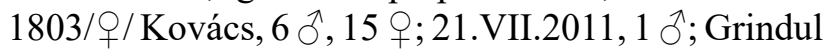
Chituc, Periboina, 15.VIII.2014, 3 ㅇ, 24.VIII.2017, 3 ภ, 15.VIII.2019, 4 ภ, 3 ㅇ, legit \& coll. S. \& Z. Kovács, collected at light in halophytic habitats from the Black Sea coastal zone.

Scrobipalpa atriplicella (FISCHER VON RöSLERSTAMM, 1841) is common and widely distributed in the Palaearctic region, introduced to North America; larvae feed on Atriplex and Chenopodium species (Chenopodiaceae) (HUEMER \& KARSHOLT 2010: 129). In Romania is known from Dobrogea (MANN 1866: 353), Moldova (CARADJA 1899: 204; NeMEŞ \& DĂNILĂ 1970: 184), Transylvania (RothSCHILD 1912a: 29; RÁKosy 2002: 67, as Ilseopis atripicella) and Crişana (KovÁcs \& KovÁcs 2001: 96). We examined recently collected material from the Transylvanian Basin (Lechinţa, Viişoara), Apuseni Mountains (Cheia), Eastern Carpathians (Baraolt, Ciuc Mountains) and Dobrogea (Măcin Mountains, Cetatea Histria, Vama Veche, Hagieni, Canaraua Fetii) (legit \& coll. S. \& Z. Kovács). First record for Muntenia: Breaza (Buzău County), $350 \mathrm{~m}$, 20.IX.2004, 1 §ో; 22.IX.2004, 1 §̂, legit \& coll. V. Dincă.

Scrobipalpa artemisiella (TREITSCHKE, 1833) is widely distributed throughout Europe, and from Syria to Mongolia and China. Its confirmed host-plants are the Thymus species (Lamiaceae) (HuEMER \& KARSHOLt 2010: 139). It is common and widespread in Romania, but so far recorded only from Dobrogea (MANN 1866: 353), Moldova (HormuZaKi 1907: 83), Transylvania (Czekelius 1918: 44) and Crişana (KovÁcs \& Kovács 2001: 96). Recently it was collected from several Transylvanian sites (legit \& coll. S. \& Z. Kovács).

Scrobipalpa gallicella (CONSTANT, 1885) (Figs 45-46) is distributed throughout southern Europe from Spain and France through Hungary and Ukraine to the Volga region and the southern Ural Mountains in Russia. Larvae feed on Artemisia species (Asteraceae) (Huemer \& Karsholt 2010: 151). First record for the Romanian fauna: Câmpia Transilvaniei, Lechinţa (Mureş County) 17.V.1996, 1 đ̂; 13.IV.2002, genitalia

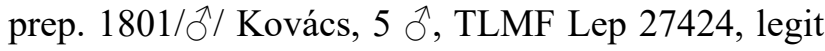
\& coll. S. \& Z. Kovács. The specimens were attracted to light in a xerothermic meadow. The sequenced specimen clustered into the BIN BOLD:ADG6801 together with specimens from France, but to $1.28 \%$ p-distance (BOLD Systems, accessed 30 December 2020). 
Scrobipalpa nitentella (FUCHS, 1902) (Figs 4748 ) is widely distributed in the Palaearctic region from Tunisia, through Europe to Transbaikal in Asiatic Russia, and from Turkey to Afghanistan, Mongolia and China (Huemer \& Karsholt 2010: 156). According to RÁKosY \& GoIA (2021: 58, $217)$ it is a species without voucher material from Romania, mentioned only in the European checklists by PovolNÝ (1996: 114) and KARSHOLT (2004-2020) (accessed 17 November 2021). Now we can confirm the presence of the species based on material attracted to light from several sites around the Sinoe-Razelm lagoon complex of the Black Sea coastal zone and a few inland localities in Dobrogea. Material examined: Dobrogea, Cetatea Histria, 25-26.VIII.1999, genitalia prep. 1179/\&/ Kovács, 1 \&; 27.VII.2000, genitalia prep. 1813/ð/ Kovács, 1 ภे; 11.VIII.2001, 1 ภ, 3 क ; 27.VII.2006, 3 o, 1 q; Dobrogei Gorge, 29.VII.2000, 1 \%; Măcin Mountains, Greci, 150-200 m, 10.VIII.2001, 2 क; Jurilovca, Capul Doloșman,

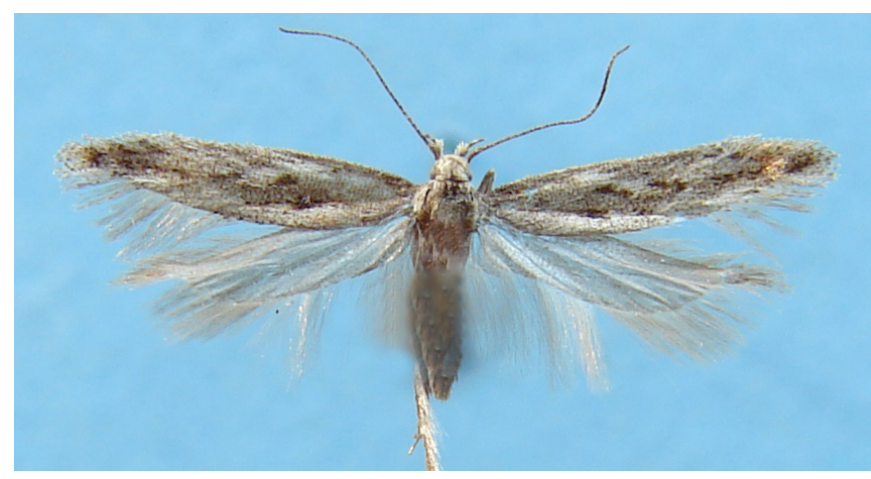

Fig. 45. Scrobipalpa gallicella (CoNSTANT, 1885): adult, male, wingspan $11 \mathrm{~mm}$, Câmpia Transilvaniei, Lechinţa (Mureş County) 13.IV.2002, legit \& coll. S. \& Z. Kovács.

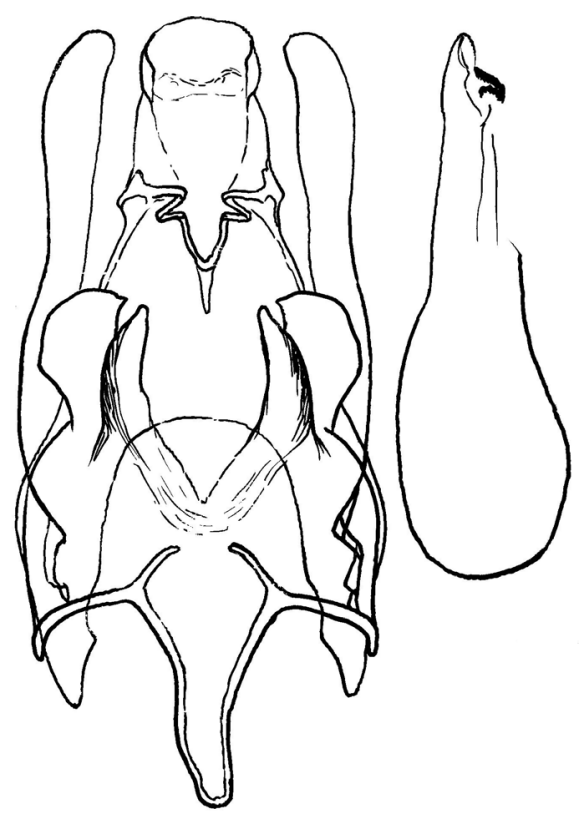

Fig. 46. Scrobipalpa gallicella (CONSTANT, 1885): free floating male genitalia in ventral view, genitalia prep. 1801, same data as Fig. 45.
20.VIII.2009, genitalia prep. 1814/o and 1815/9/ Kovács, 1 đ̊, 6 P; Sarichioi (salt marsh), 21.VIII.2009,

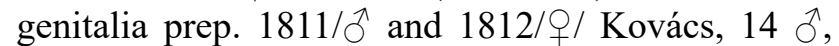
8 क; Grindul Chituc, Peribiona, 14.VIII.2014, 4 ô, 4 क; 15.VIII.2014, 4 ठิ, 9 क; 24.VIII.2017, 7 ô, 5 9, 15.VIII.2019, 18 §, 12 q, legit \& coll. S. \& Z. Kovács; Grindul Chituc, Peribiona, 8-9.VIII.2011, 5 , legit R. Kis \& I. Kovács, coll. S. \& Z. Kovács. This is the first evidence based record of the species from Romania.

Scrobipalpa hyoscyamella (STAINTON, 1869) is only known from Spain, southern France, southeastern Austria, Romania (HuEmer \& Karsholt 2010: 159) and southern Russia (LEPIFORUM, accessed 4 December 2020). In Romania it was recorded for the first time from Ineu in Crişana (legit \& coll. L. Diószeghy, material examined and

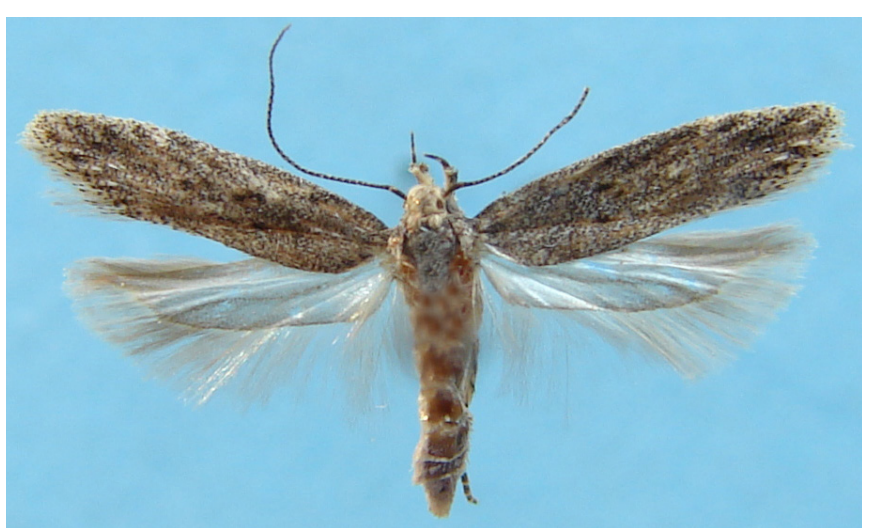

Fig. 47. Scrobipalpa nitentella (FucHS, 1902): adult, male, wingspan $12 \mathrm{~mm}$, Dobrogea, Grindul Chituc, Periboina, 24.VIII.2017, legit \& coll. S. \& Z. Kovács.

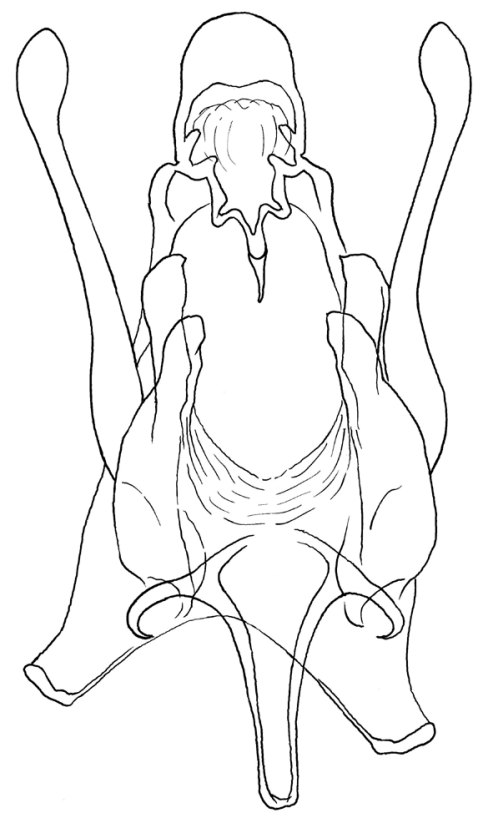

Fig. 48. Scrobipalpa nitentella (FUCHS, 1902): free floating male genitalia (except the phallus) in ventral view, Dobrogea, Cetatea Histria, 27.VII.2000, genitalia prep. 1813, legit \& coll. S. \& Z. Kovács. 
identified by P. Huemer) by Kovács \& Kovács (2001: $89,97)$. Previously it was misidentified and published as $S$. costella (Humphreys \& Westwood, 1845) (DiósZeghy 1930a: 285, as Lita; GoZMánY 1958: 209; KovÁcs \& KovÁcs 2000: 33). Recent data are not available. $S$. hyoscyamella replaces $S$. costella in the Romanian checklist (see also below in the list of deleted species).

Scrobipalpa ocellatella (BOYD, 1858) is widely distributed in Europe, North Africa and the Middle East. The larva was recorded from Chenopodiaceae as Beta (including cultivated forms of Beta vulgaris L.), Halimione, Suaeda, Salicornia and Camphorosma species (Huemer \& Karsholt 2010: 165). In Romania is widely distributed, mentioned from Dobrogea by MANN (1866: 353) and later from most of the country except Muntenia (RÁkosY \& GoIA 2021: 58). We collected it in more Dobrogean and Transylvanian sites. First record for Muntenia: Breaza (Buzău County), ca. 350 m, 20-21.IX.2002, 1 ô, legit \& coll. V. Dincă.

Scrobipalpa erichi PovOLNÝ, 1964 is distributed from Austria and the Czech Republic throught the European Turkey, the Volga-Don region in Russia and the Middle East to Mongolia and China (Huemer \& KARSHOLT 2010: 170). In Romania it was mentioned for the first time from Moldova (Suceava) by NemEŞ \& LunGOCI (1973: 241), later from Crişana (Ineu) (Kovács \& KovÁcs 2000: 33; 2001: 97). Recently it was collected from Dobrogea (Măcin Mountains, Pricopan Peak, 26.VII.2000, 1 ơ; 14-24.IX.2002, 1 ठิ; 2-14.X.2006, genitalia prep. 1975/ふ// Kovács, 1 ${ }^{7}$; Dobrogei Gorge, 29.IV.2013, 1 영 Grindul Chituc, Periboina, 15.VIII.2019, 2 ô, legit \& coll. S. \& Z. Kovács) and Muntenia (Breaza, Buzău County, 2629.IV.2003, 1 đ̃, 3 ㅇ, legit \& coll. V. Dincă; Câmpia Bărăganului, Mihai Bravu, 4.V.2018, 1 ㅇ, legit \& coll. S. \& Z. Kovács). These are the first records for Dobrogea and Muntenia.

Scrobipalpa monochromella (CONSTANT, 1895) (Figs 49-50) is known from scattered localities in Spain, France, Italy, Ukraine and Siberia (HuEmer \& KARSHOLt 2010: 175). First record for the Romanian fauna: Dobrogea, Grindul Chituc, Periboina, 8-9. VIII.2011, genitalia prep. 1798/ふ/ Kovács, 3 đ, legit R. Kis \& I. Kovács, coll. S. \& Z. Kovács; 15.VIII.2014,

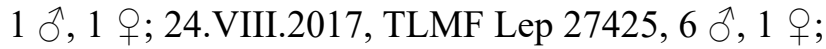
15.VIII.2019, genitalia prep. 2386/9/ Kovács, 4 đ̊, 1 +, legit \& coll. S. \& Z. Kovács. The specimens were collected at light in halophytic habitats of the Black Sea coastal zone. The sequenced specimen clustered into the BIN BOLD:ACT1265 together with two specimens from Ukraine to $0.12 \%$, and to $2.14 \%$ p-distance to another specimen from southern France (BOLD Systems, accessed 30 December 2020). Further studies are necessary to establish its correct taxonomic status, if it belongs to this or a different species.

Scrobipalpa samadensis (PFAFFENZELLER, 1870) is widely distributed throughout Europe and Turkey (Huemer \& Karsholt 2010: 176). In Romania it was mentioned for the first time from Moldova (Ițcani) by Nemeş \& Lungoci (1973: 241). Later it was recorded from the Black Sea coastal zone (Grindul Chituc, Vadu) by Kovícs \& Kovács (2000: 31). More recently we collected material from a halophytic habitat in the Eastern Carpathians (Praid, 28.V.2000, 1 क; 18.VIII.2000, 21 ô, 11 \%, legit \& coll. S. \& Z. Kovács) which is the first record for Transylvania.

Scrobipalpa salicorniae (HERING, 1889) is

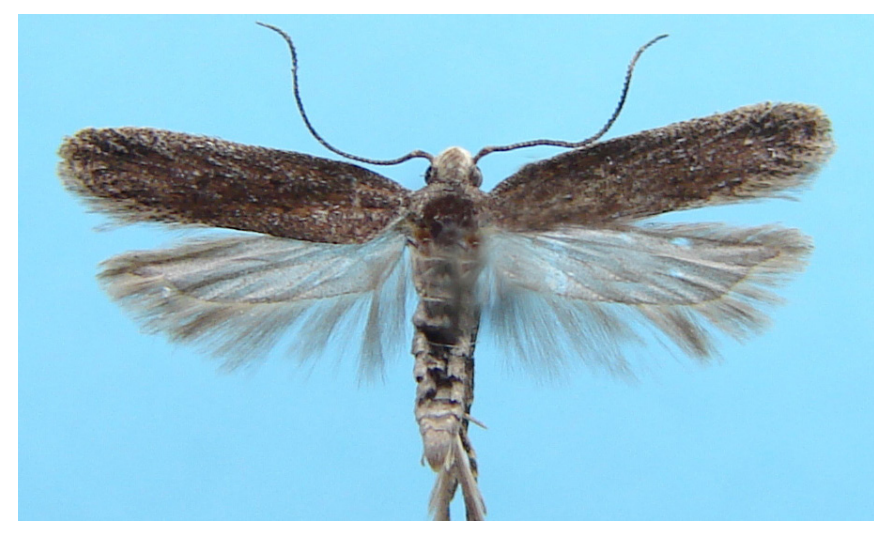

Fig. 49. Scrobipalpa monochromella (CONSTANT, 1895): adult, male, wingspan $12.5 \mathrm{~mm}$, Dobrogea, Grindul Chituc, Periboina, 8-9.VIII.2011, legit R. Kis \& I. Kovács, coll. S. \& Z. Kovács.

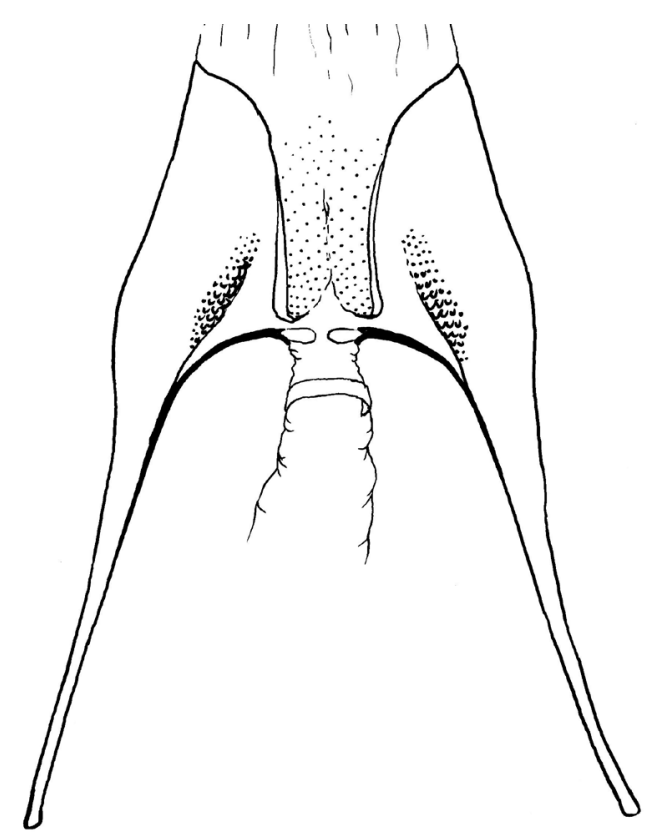

Fig. 50. Scrobipalpa monochromella (CONSTANT, 1895): segment VIII and posterior part of ductus bursae of the female genitalia in ventral view, Dobrogea, Grindul Chituc, Periboina, 15.VIII.2019, genitalia prep. 2386, legit \& coll. S. \& Z. Kovács. 
distributed in the coastal areas of northern Europe, in scattered localities in central Europe and the southern Ural Mountains, including also Romania (HuEmer \& KARShOLT 2010: 141, 181, the latter (Balchic) erroneously instead of Bulgaria). The records from Moldova (Gârboavele forest) and Dobrogea (Danube Delta) as $S$. salinella (Zeller, 1847) by Olaru \& NemEş (1969: 128) may also refer to this species. During the present study we examined a rich material from Transylvania (Turda, Viişoara, Toldal, Praid, legit \& coll. S. \& Z. Kovács) and identified it for the first time from Crișana, Dobrogea and Muntenia: Crișana, Ineu, 9.VI.1928, 1 + , legit \& coll. L. Diószeghy; Dobrogea, Cetatea Histria, 25-26.VIII.1999, 1 q ; 27.VII.2000, 1

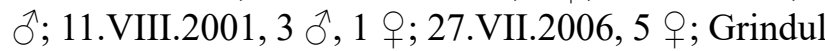
Chituc, Vadu, 28.VIII.1999, genitalia prep. 1000/ठ

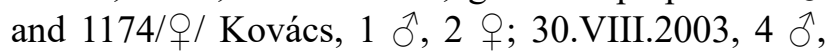
5 q; Vama Veche (coast) 25.VII. 2006, 1 o; ; Măcin Mountains, Greci, 250 m, 26.V.2007, 1 đ̄; Jurilovca, Capul Doloşman, 20.VIII.2009, 2 đ, 1 q; Sarichioi (salt marsh), 21.VIII.2009, 3 ô, 1 क; Murighiol, 22.VII.2011, genitalia prep. 1970/ $/$ / Kovács, 2 Ô, 1 \%; Enisala, 22.VII.2011, 1 ; Grindul Chituc, Periboina, 14.VIII.2014, 3 ${ }^{\Uparrow}, 4$ \% ; 15.VIII.2014, genitalia prep.

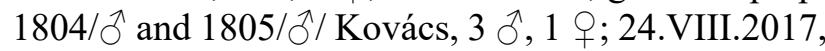
2 đ̃; Muntenia, Câmpia Bărăganului, Mihai Bravu, 4.V.2018, genitalia prep. 1972/q/ Kovács, 2 đ, 5 q, legit \& coll. S. \& Z. Kovács. Except the Măcin Mountains all Dobrogean sites are in the Black Sea coastal zone, the others are inland halophytic habitats. Most of the specimens were attracted to light, but in Turda and Praid collected also during the day by netting of the Salicornia dominated paches of the salty habitats. The specimens from Turda and one from Grindul Chituc, Vadu (28.VIII.1999, genitalia prep. 1000/ð/ Kovács) were misidentified and published as $S$. stangei (Hering, 1889) by Kovács \& Kovács (2000: 31). Two males from Turda sent for study to O. Karsholt (genitalia slide 2652 and 2702/ H. Hendricksen) initially were identified and published as $S$. salinella (RÁKosy et al. 2003: 357), finally they proved to be $S$. salicorniae (HUEMER \& KARSHOLT 2010: 141). The specimen from Ineu has also been published as S. salinella by Kovács \& Kovács (2001: 96).

In the followings we discuss some inconsistences around the type material, distribution and taxonomic status of Lita caliacrae CARADJA, 1932. In the original description $2 \widehat{A}$ specimens collected by A. Ostrogovich in B[alcic] on 14.VII.[1931] are mentioned (CARADJA 1932: 43). In the catalogue of the A. Ostrogovich collection (Popescu-GorJ 1964: 35 , as $G[$ norimoschema $]$ salicorniae caliacrella CAR.) and in the catalogue of the types in the collection of MGAB (POPESCU-GoRJ 1992: 140) also $2 \delta$ specimens are mentioned, a holotype (Balcic, 14.VII.1931, only in the latter source is mentioned the genitalia prep. 2192/Povolný) and a paratype (Balcic, Ak-Bunar valley, 15.VII.1931). Recently
Huemer \& Karsholt (2010: 181) re-examined the above mentioned material and concluded that the holotype is a $\hat{\gamma}$ collected on 14.VII.1931, which bears the genitalia slide label "2192 Car" of Povolný, but this number is connected with a female genitalia slide. The second specimen, a $q$ collected on 15.VII.1931, which lacks both abdomen and genitalia slide label, was not accepted as part of the type series, because it was not mentioned in the original description. They are on the opinion that the genitalia slides of these two specimens have been exchanged.

The type locality, Balcic was part of Romania in the time of the collecting of the specimens and the description of the species, but shortly after became and also currently is Balchic in the north-eastern part of modern Bulgaria.

Earlier it was included as a valid species in the checklist by PoPeSCu-GorJ (1984: 128) and mentioned as Romanian endemic by RÁKosY (1998: 259), but both were erroneous, because $S$. caliacrae was described from Bulgaria (Balchik) and never mentioned from the territory of modern Romania. Later it was treated as a junior synonym of $S$. salinella (e.g. Povolný 2002: 67) and mentioned with this status in the Romanian checklists (Kovács \& Kovícs 2000: 31; RÁkosy et al. 2003: 66; RÁKosy \& GoIA 2021: 58). Currently it is considered a junior synonym of S. salicorniae (HUEMER \& KARSHOLT 2020: 107).

Scrobipalpa thymelaeae (AMSEL, 1939) (Figs 51-52) has been synonymized with $S$. salinella by PovolNÝ (1964: 353), but recently reinstated to full species rank; it is a rarely recorded species, known only from Sardinia (the type locality) and Bulgaria (Tuzlata) (HuEMER \& Karsholt 2010: 184). First record for the Romanian fauna: Dobrogea, Vama Veche (coast), 18.IX.2004, 1 đ; 25.VII. 2006, genitalia prep. $1808 / \widehat{\delta} /$ Kovács, 1 ठ, legit \& coll. S. $\&$ Z. Kovács. The specimens were attracted to light.

Scrobipalpula PovolnÝ, 1964 was revised by HUEMER \& KARSHOLT (1998). Earlier the taxa of the genus were treated as a unique polytypical species with a wide distributional range (Povolný 2002: 84-86). Currently 37 Neotropical, 16 Nearctic and 5-6 Palaearctic species are recognized (HUEMER \& KARSHOLT 2010: 195). In Europe 5 species are known, they all share a single BIN, but still show species-specific DNA barcode haplotypes (HUEMER \& KARSHOLT 2020: 132). In Romania 3 species are recorded.

Scrobipalpula psilella (HERRICH-SCHÄFFER, 1854) is widely distributed throughout Europe, North Africa and parts of Asia (Huemer \& Karsholt 2010: 196). In Romania only two old records were known from Muntenia (Bucureşti) (CARADJA 1899: 204) and Moldova (Lespezi, 31.VII, 1 đ) (Nemeş \& LuNGOCI 1973: 241). First record for Transylvania: Eastern Carpathians, Baraolt Mountains, Ariuşd, 600 m, 
23.VI.2000, 1 \&; 10.VII.2001, genitalia prep. 1823/ふ// Kovács, 6 Ô, 1 of; 11.IV.2006, 1 ơ; 25.III.2011, 1

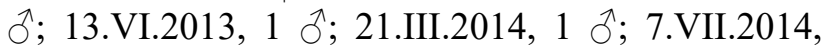
1 o; 13.VI.2015, 1 ㅇ, legit \& coll. S. \& Z. Kovács. All were attracted to light in a xerothermic low mountain steppe habitat. The collecting data indicate bivoltinism. According to HUEMER \& KARSHOLT ( $o p$. cit.) adults are on the wing from late May or June to mid-October. We found the first generation to be on the wing earlier, from the end of March to the end of April, and the second from mid-June to July.

Scrobipalpula diffluella (FREY, 1870) (Figs 53-54) was considered a boreo-montane species distributed in Scandinavia and Latvia, the Alps and the southern Ural Mountains (HuEMER \& KARSHOLT 2010: 200), but recently it was recorded also from lowlands in Hungary and Slovakia (PASTORÁlis 2014: 2; TOKÁR

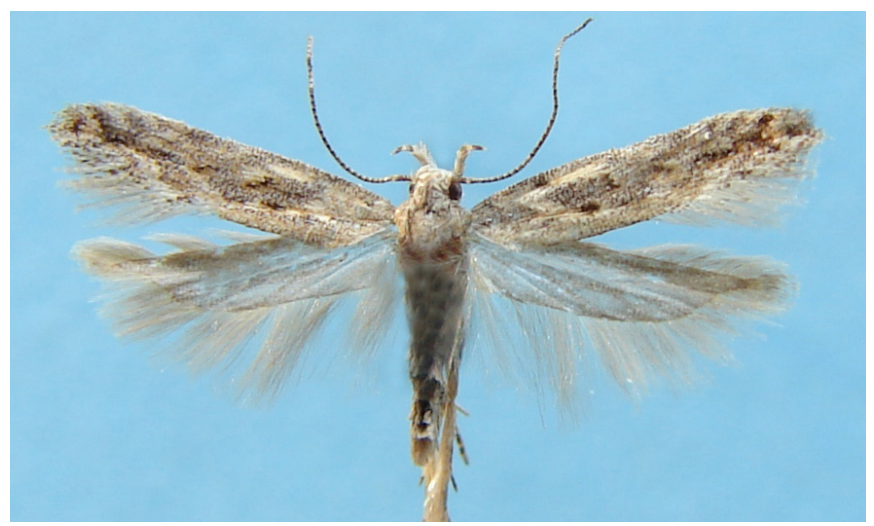

Fig. 51. Scrobipalpa thymelaeae (AmSEL, 1939): adult, male, wingspan $10.5 \mathrm{~mm}$, Dobrogea, Vama Veche (coast), 18.IX. 2004, legit \& coll. S. \& Z. Kovács.

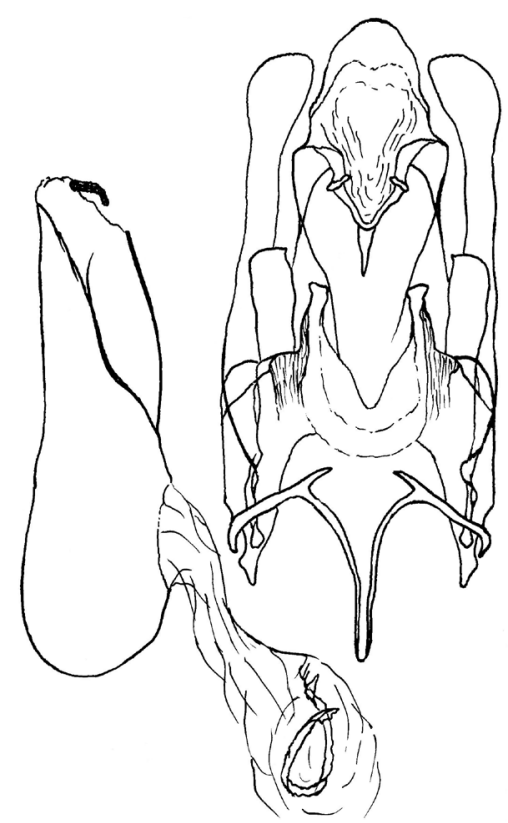

Fig. 52. Scrobipalpa thymelaeae (AMSEL, 1939): free floating male genitalia in ventral view, Dobrogea, Vama Veche (coast), 25.VII. 2006, genitalia prep. 1808, legit \& coll. S. \& Z. Kovács. et al. 2015: 43). In Romania a record as Gelechia cacuminum FREY from the highest mountains of Transylvania (Făgăraş Mountains, Catiave, 2200 m) by Czekelius (1918: 44) attributed to this species by RÁKosy \& GoIA $(2021: 59,218)$ refers to Scrobipalpa murinella. However, a record as Scrobipalpa murinella (Nemeş \& Lungoci 1973: 241) from low altitudes in the environs of Suceava may refer to this species (see also above to $S$. murinella). According to Kovícs \& KovÁcs (2000: 33) its presence in Romania is in need of confirmation. At this time we confirm its presence with the following voucher material: Transylvania, Apuseni Mountains, Trascău Mountains, Piatra Secuilor (Rimetea), 5.VII.2000, genitalia prep. 1788/ふ// Kovács, 2 ふૈ; 31.III.2017, 1 సं; Apuseni Mountains, Gilău Mountains, ScăriţaBelioara, 900m, 17.VII.2015, 2 ô, 1 O; 1.IV.2017, 12 đิ, 2 q, legit \& coll. S. \& Z. Kovács. All were

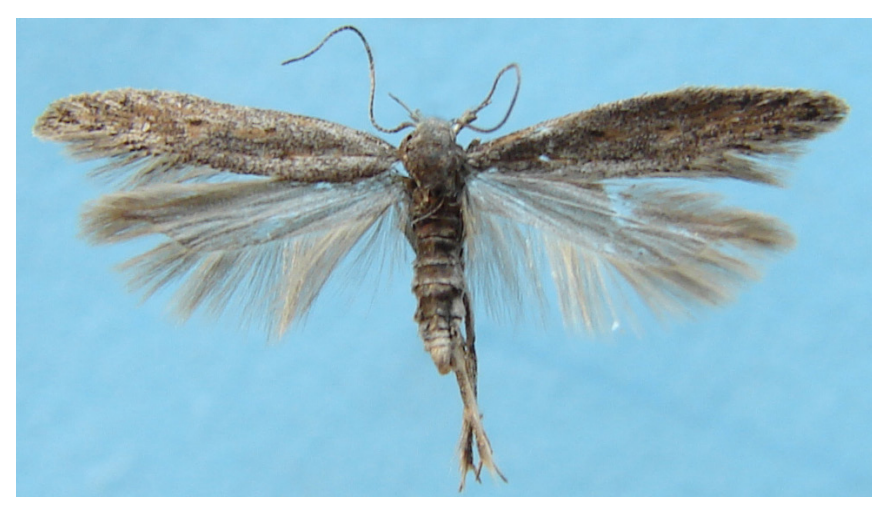

Fig. 53. Scrobipalpula diffluella (FREY, 1870): adult, male, wingspan $14 \mathrm{~mm}$, Apuseni Mountains, Trascău Gilău, 900 m, Scăriţa-Belioara, 1.IV.2017, legit \& coll. S. \& Z. Kovács.

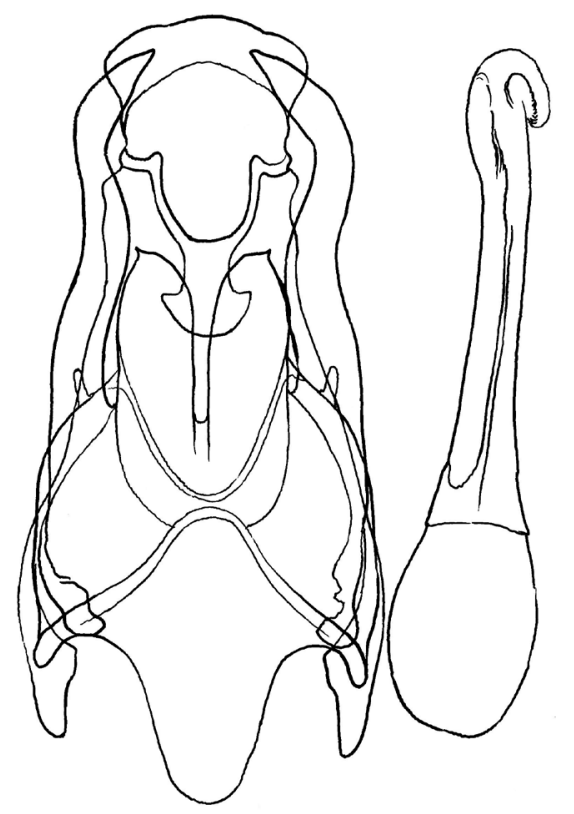

Fig. 54. Scrobipalpula diffluella (FREY, 1870): free floating male genitalia in ventral view, Apuseni Mountains, Trascău Mountains, Piatra Secuilor (Rimetea), 5.VII.2000, genitalia prep. 1788 , legit \& coll. S. \& Z. Kovács. 
attracted to light in xerothermic mountain meadows; the collecting data indicate bivoltinism, the first generation from the very end of March to the end of April, the second in July.

Scrobipalpula tussilaginis (STAINTON, 1867) (Figs 55-56) is distributed in most of Europe except the Iberian Peninsula and major parst of the Mediterranean, extending eastwards to Siberia (HUEMER \& KARSHOLT 2010: 201). According to RÁKosY \& GoIA (2021: $59,218)$ it is a species without voucher material in Romania, mentioned only in checklists (POPESCUGorJ 1984: 128; Kovács \& Kovács 2000: 18, 33). Recently a single male specimen was collected in the Eastern Carpathians, Ciuc Depression, Şumuleu (Miercurea Ciuc), 700 m, 8.VI.2011, genitalia prep. 1825/ð/ Kovács, 1 đ, legit \& coll. S. \& Z. Kovács. It can be considered the first record for the Romanian fauna.

Phthorimaea Meyrick, 1902 is a Neotropical

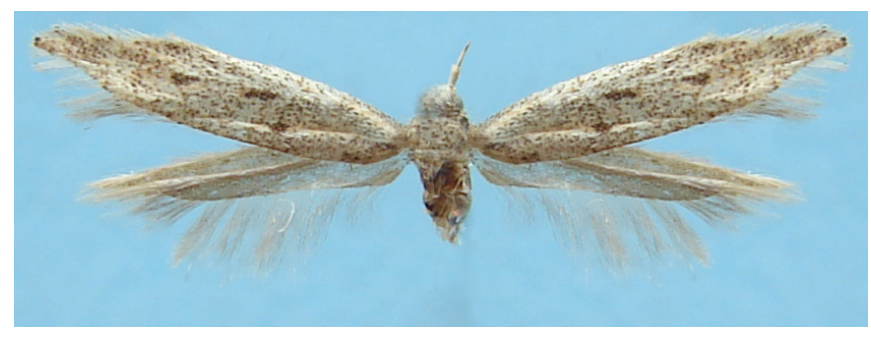

Fig. 55. Scrobipalpula tussilaginis (STAINTON, 1867): adult, male, forewing length $5.5 \mathrm{~mm}$, Eastern Carpathians, Ciuc Depression, Şumuleu (Miercurea Ciuc), 700 m, 8.VI.2011, genitalia prep. 1825, legit \& coll. S. \& Z. Kovács (the right wings missing, digitally reconstructed with the left ones).

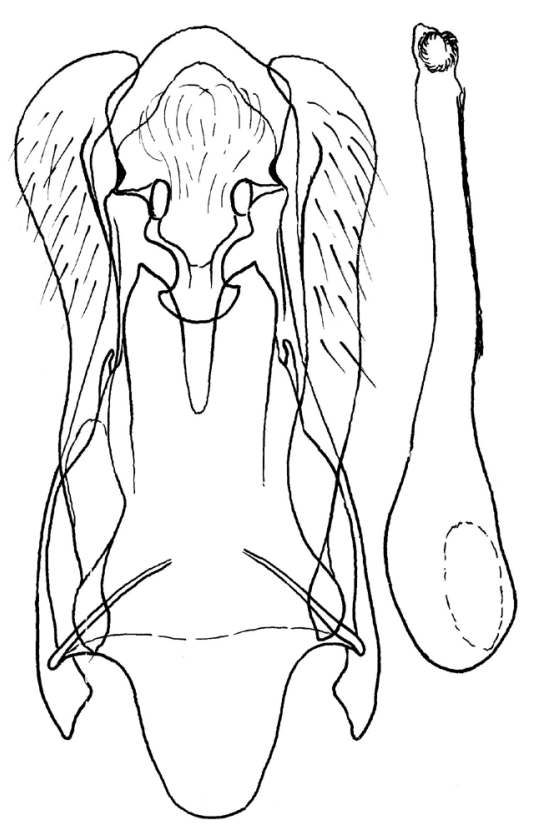

Fig. 56. Scrobipalpula tussilaginis (STAINTON, 1867): free floating male genitalia in ventral view, genitalia prep. 1825 , same data as Fig. 55. genus with its type species, $P$. operculella introduced to vast areas of the tropical and subtropical regions, and also to Europe (HuEMER \& Karsholt 2010: 202) including Romania.

Phthorimaea operculella (ZeLLER, 1873), the Potato Tuber Moth is an invasive species of Neotropical origin, a pest of the potato. The larval host-plants are various Solanaceae (HuEMER \& KARSHOLt 2010: 203). In Romania it was listed by POPESCU-GoRJ (1984: 128) and subsequently by PovolnÝ (1996), Kovács \& Kovács (2000: 33) and RÁkosy et al. (2003: 67, 258), but all without any more specific location. First time it was found on potato crops near Constanţa (Dobrogea) by DoNESCU (2009: 71), later recorded also from Transylvania (CIOBANU et al. 2010: 25). As the $10{ }^{\circ} \mathrm{C}$ isotherm is thought to be the natural limit for its spread, further dispersal is expected in Romania, representing a well-founded threat to the potato crops. The record for Dobrogea was omitted by RÁkosy \& Goia (2021: 59).

Tuta KiefFer \& Jørgensen, 1910 is a Neotropical genus, represented in Europe with a single invasive species.

Tuta absoluta (MeYrick, 1917), the Tomato Leaf Miner, is an invasive species of Neotropical origin, introduced to Europe in 2007 (for more details see HuEMER \& KARSHOLT 2010: 204). Being a pest of tomato and other cultivated Solanaceae it has an enormous printed and internet literature (KARSHOLT et al. 2013: 335). It was recently recorded from a greenhouse in north-eastern Romania (Botoşani County) by LeaOtĂ (2009). CEAN \& Dobrin (2010) recorded the species from further sites in Moldova, Transylvania and Muntenia exclusively from greenhouses, and in warehouses on tomato imported from Spain and Turkey. Later it was recorded from most of the country except Dobrogea (RÁKosY \& GoIA 2021: 59). We examined material from Oltenia (Hinova, legit \& coll. S. \& Z. Kovács) and Dobrogea (Grindul Chituc, Periboina, 14-17.X.2015, genitalia prep. 1979/ふ/ Kovács, 1 ○, 1 ㅇ, legit R. Kis \& I. Kovács, coll. S. \& Z. Kovács). The specimens were attracted to light, at the Black Sea coastal area far away from localities and agricultural fields, and in Oltenia in a xerothermic habitat in the vicinity of a settlement. These are the first records of the species from the wild nature in Romania and the first record for Dobrogea.

Ephysteris MeYrick, 1908 is a taxonomically difficult genus, almost worldwide distributed, with a concentration of species in the eremic parts of the Eastern Hemisphere (Huemer \& KarSholt 2010: 209). In Europe 9 species were recorded (HuEMER \& KARSHOLT 2020: 108), only 4 are known from Romania. 
Ephysteris promptella (STAUDINGER, 1859) is widely distributed in the southern parts of the Palaearctic region extending eastwards to China, recorded in the Middle East, southern and eastern Africa, and the Indo-Australian region (HUEMER \& KARSHOLT 2010: 210). In Europe four BINs are recognized (HUEMER \& KARSHOLT 2020: 130). In Romania it was mentioned for the first time from Moldova (Suceava, 27.IX, 1 ㅇ) by Nemeş \& LungOCI (1973: 241). Later data from Crişana (Ineu, 31.VII.1931, 1 ¡ે, legit \& coll. L. Diószeghy) and Dobrogea (Măcin Mountains, Canaraua Fetii, Lespezi, legit \& coll. S. \& Z. Kovács) were published by Kovács \& Kovács (2000: 33; 2001: 97). A record from Moldova (Agapia, Neamţ County, 4.VIII.1971, 1 ) as Ephysteris subdiminutella StaINTON by Nemeş (1974: 209) may also refer to this species. Recently it was collected from several Dobrogean sites, where it is widespread and frequent. First records

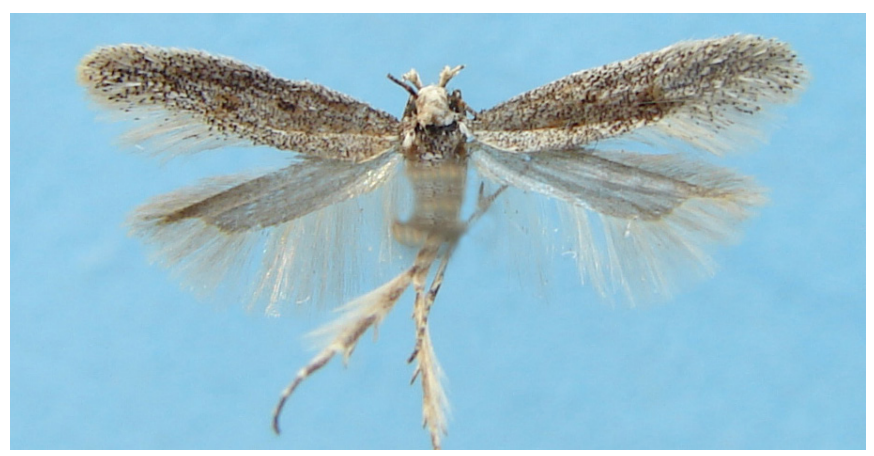

Fig. 57. Ephysteris deserticolella (STAUDINGER, 1871): adult, male, wingspan 11.5 mm, Muntenia, Câmpia Bărăganului, Mihai Bravu, 4.V.2018, legit \& coll. S. \& Z. Kovács.

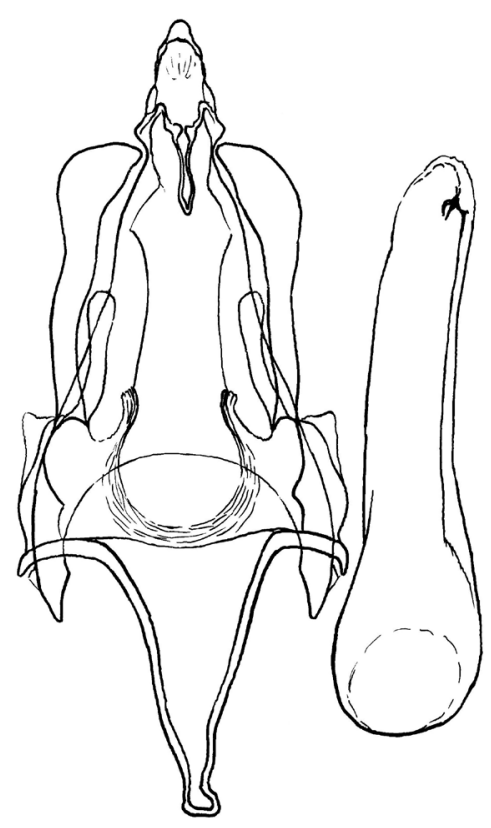

Fig. 58. Ephysteris deserticolella (STAUDINGER, 1871): free floating male genitalia in ventral view, Dobrogea, Sarichioi (salt marsh), 21.VIII.2009, genitalia prep. 1827, legit \& coll. S. \& Z. Kovács. for Transylvania and Oltenia: Transylvanian Basin, Viişoara, 18.IX.2015, genitalia prep. 1824/9/ Kovács, 5 o, 6 क; Oltenia, Hinova, 150 m, 21.IX.2019, 1 क; Oltenia, Schela Cladovei, 100 m, 22.IX.2019, 1 $\widehat{\delta}, 1$ + , legit \& coll. S. \& Z. Kovács. Material collected in Romania has not yet been genetically examined.

Ephysteris deserticolella (STAUDINGER, 1871) (Figs 57-58) is distributed in halophytic habitats and eremic parts of south-eastern and southern Europe and the Near East (Huemer \& Karsholt 2010: 212). First record for the Romanian fauna: Dobrogea, Grindul Chituc, Vadu, 30.VIII.2003, 4 गे; 15.IX.2006, 2 §; Dobrogea, Sarichioi (salt marsh), 21.VIII.2009, genitalia prep. 1827/ð/ Kovács, 9 Љ่; Muntenia, Câmpia Bărăganului, Mihai Bravu, 4.V.2018,

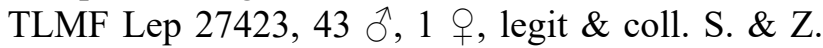
Kovács; Dobrogea, Grindul Chituc, Periboina, 29-30. VIII.2009, 1 ô, legit R. Kis \& I. Kovács, coll. S. \& Z. Kovács. All were attracted to light in both coastal and inland halophytic habitats. A recently barcoded specimen clustered into the BIN BOLD:ACT4402 to $0.16 \% \mathrm{p}$-distance to a specimen from Crimea (BOLD Systems, accessed 12 December 2020).

Ephysteris insulella (HEINEMANN, 1870) was mentioned for the Romanian fauna based on material from Crişana (Ineu, legit \& coll. L. Diószeghy) and the Black Sea coastal zone (Grindul Chituc, Vadu, legit \& coll. S. \& Z. Kovács) (Kovács \& Kovács 2000: 33). Recently we collected it from other coastal habitats in Cetatea Histria, Periboina and Vama Veche. All of the specimens belong to the ssp. praticolella (CHRISTOPH, 1872), characterized by lighter, cream-white colour of the forewing and distributed from south-western Russia through the Balkan Peninsula to Italy (HUEMER \& KARSHOLT 2010: 213).

Ephysteris diminutella (ZeLLER, 1847) is distributed in southern Europe from the Iberian to the Balkan Peninsula, but clusters into two geographically separated BINs requiring taxonomic re-evaluation (Huemer \& Karsholt 2020: 132). In Romania it was recorded from Dobrogea (Măcin Mountains, Pricopan Peak, legit \& coll. S. \& Z. Kovács) by Kovícs \& Kovács (2000: 33) as E. treskensis PovolnÝ, 1966, and later collected from two other Dobrogean sites (Dobrogei Gorge, Cotu Văii, legit \& coll. S. \& Z. Kovács). First record for Transylvania: Apuseni Mountains, Trascău Mountains, Rimetea, 5.VII.2000, 5 Õ, 1 o, legit \& coll. S. \& Z. Kovács. Ephysteris treskensis was synonymized with $E$. diminutella by HuEMER \& Karsholt (2010: 214-217) and is treated even currently (HuEMER \& KaRSHOLt 2020) despite this status is not supported by the results of the genetic studies (HuEMER et al. 2020, supplementary material 2, NJ tree 25). Material collected in Romania has not yet been genetically examined. 
Cosmardia PovolnÝ, 1965 is a monotypic genus restricted to the western part of the Palaearctic region, extending eastwards to western and southern Siberia (HuEmer \& Karsholt 2010: 230). It is one of the very few Gelechiidae which are known to hibernate as an adult (HUEMER \& SATTLER 1995: 12).

Cosmardia moritzella (TReItschKe, 1835) in Romania is known in Transylvania from Buza, 4.V.1911, 1 ex., legit K. Predota (RothSCHILD 1912a: 29) and Turda, IV. (SzILÁDy 1915: 75), and in Crişana from Ineu, 2.VII.1936, 1 ex., legit \& coll. L. Diószeghy (Kovács \& Kovács 2001: 97). First record for Banat: Băile Herculane, 250 m, 24-25.IX.2019, 1 ô, legit \& coll. S. \& Z. Kovács.

Lutilabria PovolnÝ, 1965 is a genus with poorly known biology and extremly scattered distribution from Croatia and Slovenia through Greece and Ukraine to Russia and Mongolia (PovolnÝ 2002:

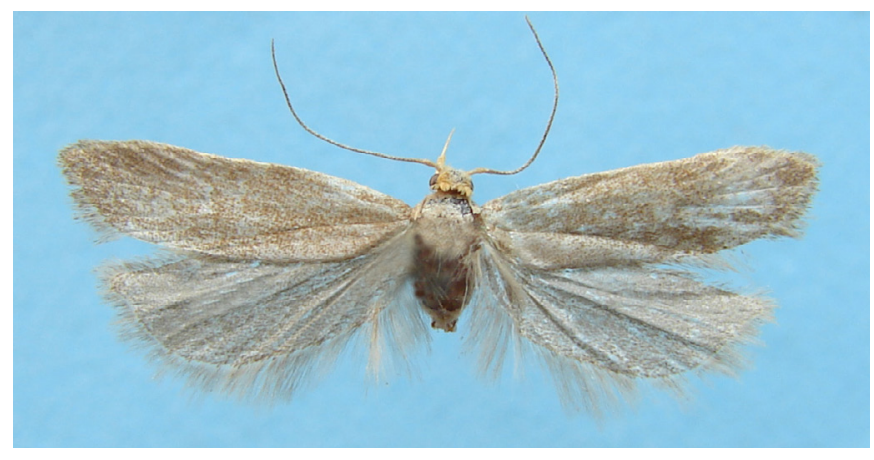

Fig. 59. Lutilabria lutilabrella (MANN, 1857): adult, male, wingspan $17.5 \mathrm{~mm}$, Dobrogea, Dobrogei Gorge, 1.VI.2014, genitalia prep. 2017, legit \& coll. S. \& Z. Kovács.

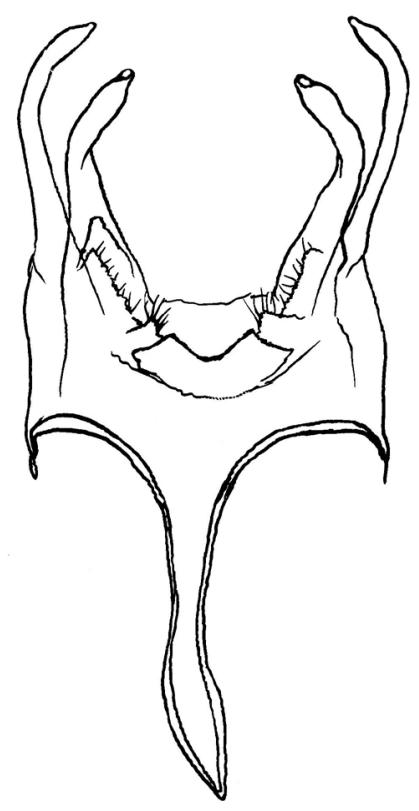

Fig. 60. Lutilabria lutilabrella (MANN, 1857): details of free floating male genitalia (vinculo-valvular complex) in ventral view, genitalia prep. 2017, same data as Fig. 59.
104; Huemer \& Karsholt 2010: 232). 5 species are described, 3 were recorded in Europe, 2 of them are known from Romania.

Lutilabria lutilabrella (MANN, 1857) (Figs 5960 ) is a rare species, only a few specimens are known from Croatia, Slovenia, Greece, Bulgaria, Ukraine (Huemer \& Karsholt 2010: 233), Albania (PovolnÝ 2002: plate 15, 104) and Slovakia, latter with separate BIN requiring taxonomic re-evaluation (HUEMER \& KARSHOLt 2020: 133). First record for the Romanian fauna: Dobrogea, Dobrogei Gorge, 1.VI.2014, genitalia prep. $2017 / \hat{\delta} /$ Kovács, $1 \hat{\jmath}$, legit $\&$ coll. S. $\&$ Z. Kovács. The specimen was collected at light in a steppe habitat on limestone. Material collected in Romania has not yet been genetically examined.

Lutilabria prolata JUNNILAINEN \& NUPPONEN, 2010 was described based on 9 males, most of them collected in the southern Ural Mountains (Russia) and only one from Romania, Dobrogea, Măcin Mountains, Greci, 100-300 m, 3.VI.1997, legit C. Wieser, coll. LMKK (JUNNILAINEN \& NUPPONEN 2010: 28). The Romanian specimen was figured by HUEMER \& KARSHOLT (2010: plate 14, fig. 143b), without the mention that it is a paratype. Later it was recorded also from Ukraine (HuEMER \& KARSHOLT 2010: 235). The female and early stages are still unknown. The species was overlooked and not included in the checklist by RÁkosy \& GoIA (2021: 59).

Klimeschiopsis PovolnÝ, 1967 is Holarctic; five species are known in the Palaearctic region, four in Europe (HUEMER \& KARSHOLt 2010: 235) and only one in Romania.

Klimeschiopsis kiningerella (DUPONCHEL, 1843) is the most widely distributed species of the genus, from France to Turkey, northwards to Scandinavia (Huemer \& Karsholt 2010: 236). In Romania there are published data from the Retezat Mountains (CzeKelius 1924: 256; Diószeghy 1930a: 285), Crişana (Ineu) (Kovács \& Kovács 2001: 97) and one specimen from Dobrogea (Șipotele, legit C. Wieser, coll. LMKK) was sequenced (HUEMER et al. 2020, supplementary material 2, NJ tree 23; BOLD Systems, accessed 30 December 2020). Unpublished material is known from the Eastern Carpathians, Apuseni Mountains and Dobrogea (Măcin Mountains, Pricopan Peak, 150-200 m, 14-15.IX.1994, genitalia prep. 997/O/ Kovács, 2 + , 24.VIII.1999, genitalia prep. 999/早/ Kovács, 1 ㅇ, Şipote, Dumbrăveni, Ostrov), all legit \& coll. S. \& Z. Kovács. The record for Dobrogea in RÁKosy et al. (2003: 67) has been based on the above mentioned and until now unpublished field records from the Măcin Mountains. Probably it is more widely distributed across the country than currently known. 
Caryocolum GREGOR \& POVOLNÝ, 1954 is Holarctic in distribution, the larval host-plants are exclusively Caryophyllaceae species; it was revised by HuEmer (1988). Over 80 species are described, in Europe 62 are known. Recent DNA analyses reveal a remarkable amount of unresolved taxonomic problems within the genus (Huemer \& Karsholt 2020: 133; Huemer et al. 2020; Huemer 2020). Currently we deal with 21 species in the Romanian fauna, but two of them are still unidentified, probably undescribed species.

Caryocolum fischerella (TREITSCHKE, 1833) is a central and eastern European species (HuEMER \& KARSHOLT 2010: 235). In Romania it was mentioned from Dobrogea (Tulcea) (MANN 1866: 353) and Moldova (Suceava) (PoPescu-Gorj \& NeMEş 1965: 158; NeMEŞ \& DĂNILĂ 1970: 183). First record for Transylvania: Eastern Carpathians, Ciuc Mountains, Racu, Cseretetö, 650 m, 19.VIII.2004, genitalia prep. 1996/ð/ Kovács, 1 §; Depresiunea Ciuc, Şumuleu (Miercurea Ciuc), 700 m, 9.VIII.2010, 1 ô, legit \& coll. S. \& Z. Kovács. The specimens were attracted to light.

Caryocolum tischeriella (ZELLER, 1839) is widely distributed in most of Europe except the northernmost areas and parts of the Mediterranean (HuEMER \& KARSHOLT 2010: 241). In Europe there are three BINs without geographical separation (HUEMER \& KARSHOLt 2020: 133). In Romania it was mentioned from the Bicaz Gorge (Eastern Carpathians) by Kovács \& Kovács (1994: 43), which so far is the single known collecting site of the species. Material collected in Romania has not yet been genetically examined.

Caryocolum alsinella (ZELLER, 1868) is local in Europe, North Africa, Turkey; extending eastwards through the Altai Republic to Lower Amur region in Russia. Its host-plants are Cerastium, Arenaria and Minuartia species (HuEMER \& KARSHOLt 2010: 242; ŠUMPICH et al. 2020: 66). Sequenced specimens cluster into three strongly different BINs in Europe (Huemer \& Karsholt 2020: 133). In Romania it was recorded for the first time from Dobrogea (Măcin Mountains) by WiESER et al. (2000: 69) and omitted from the checklist of the Romanian Gelechiidae by Kovícs \& KovÁcs (2000: 18). Later it was collected also in Transylvania (Apuseni Mountains) by RÁKosY \& WIESER (2010: 54). We collected it only in the Măcin Mountains in June and again in August and September. Probably it is more widely distributed across the country than currently known. Material collected in Romania has not yet been genetically examined.

Caryocolum vicinella (DoUglas, 1851) is widely distributed in continental Europe (HuEMER \& KARSHOLt 2010: 245). In Europe DNA barcodes cluster in four BINs, requiring taxonomic reevaluation (Huemer \& Karsholt 2020: 133). In Romania is known with old records from the Retezat Mountains (Diószeghy 1930a: 285; Kovács \& Kovács 2001: 97) and Moldova (Rarău Mountains) (Peiu \& Nemeş 1970: 60). Recently it was collected from Transylvania (Eastern Carpathians, Apuseni Mountains, legit \& coll. S. \& Z. Kovács). It seems to be a frequent and widespread species in the Carpathians. Material collected in Romania has not yet been genetically examined.

Caryocolum amaurella (HERING, 1924) (Figs 61-62) is a widespread species with scattered records from Europe and the Near East (HuEMER \& KARSHOLt 2010: 247). First record for the Romanian fauna: Apuseni Mountains, Trascău Mountains, Piatra Secuilor (Rimetea), 5.VII.2000, genitalia prep.

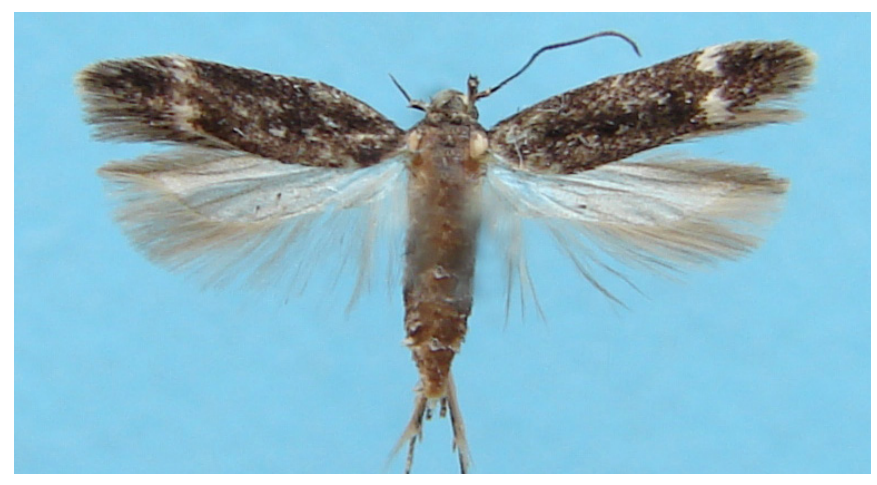

Fig. 61. Caryocolum amaurella (HeRING, 1924): adult, male, wingspan $12 \mathrm{~mm}$, Apuseni Mountains, Trascău Mountains, Piatra Secuilor (Rimetea), 5.VII.2000, legit \& coll. S. \& Z. Kovács.

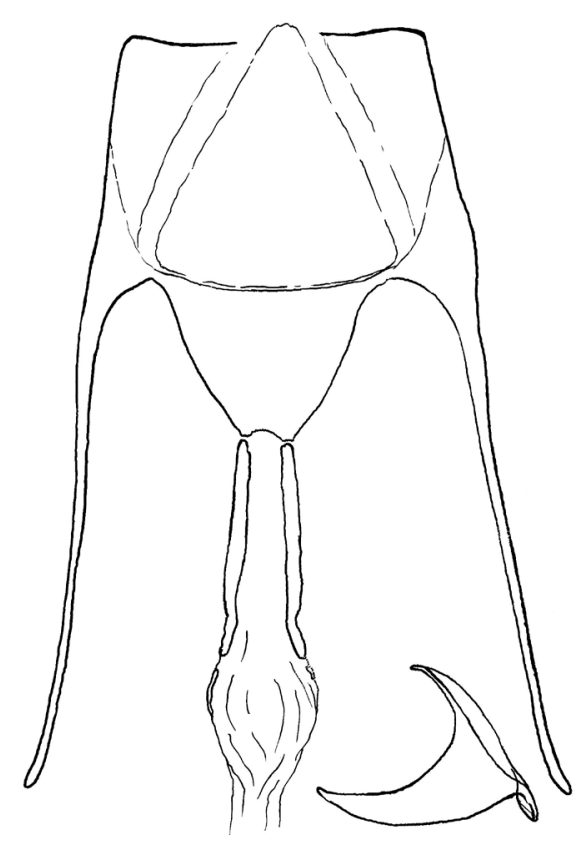

Fig. 62. Caryocolum amaurella (HeRING, 1924): segment VIII, posterior part of ductus bursae and signum of the female genitalia in ventral view, genitalia prep. 2001, same data as Fig. 61. 
2001/9/ Kovács, 18 ð, 7 q, legit \& coll. S. \& Z. Kovács. All of the specimens were collected at light in a xerothermic mountain meadow.

Caryocolum petryi (HofMAnN, 1899) (Figs 63-64) is restricted to the limestone areas of the Palaearctic region with scattered records from the Pyrenees and Alps through Hungary, some localities in northern Europe, Mongolia, in Russia the southern Ural Mountains, Transbaikal region (HuEMER \& KARSHOLT 2010: 250) and Altai Republic (ŠumPICH et al. 2020: 69). First record for the Romanian fauna: Oltenia, Schela Cladovei, 100 m, 22.IX.2019, genitalia prep. 2263/ð/ Kovács, 32 ○̄, 12 +, legit \& coll. S. \& Z. Kovács. All of the specimens were collected at light in a xerothermic mountain meadow at low altitude.

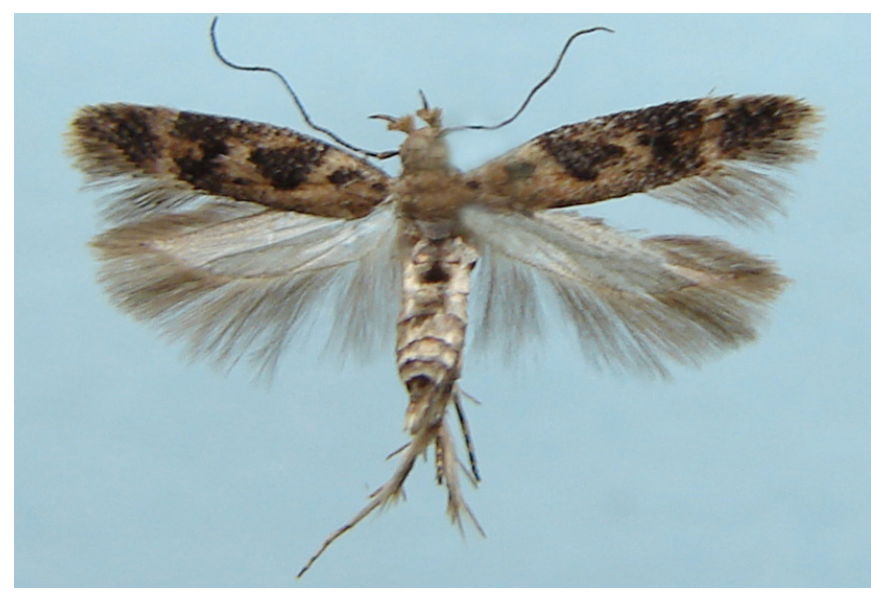

Fig. 63. Caryocolum petryi (Hofmann, 1899): adult, male, wingspan $12 \mathrm{~mm}$, Oltenia, Schela Cladovei, $100 \mathrm{~m}$, 22.IX.2019, legit \& coll. S. \& Z. Kovács.

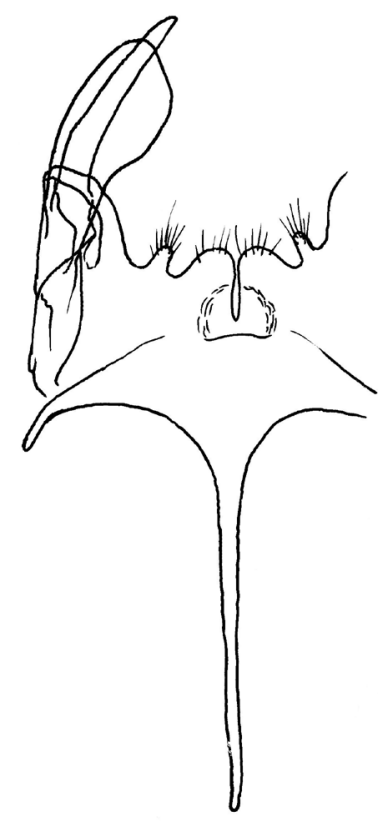

Fig. 64. Caryocolum petryi (Hofmann, 1899): details of free floating male genitalia (part of vinculo-valvular complex) in ventral view, genitalia prep. 2263 , same data as Fig. 63.
The Romanian specimens resemble the nominotypical subspecies.

Caryocolum inflativorella (KLIMESCH, 1938) is known only from a few central European countries (Slovakia, Hungary, Romania), additionally from North Macedonia and Turkey (HuEMER \& KARSHOLT 2010: 254). In Romania it was recorded from the Eastern Carpathians (Harghita Mountains) based on a single male by Kovács \& Kovács (2000: 33).

Caryocolum sp.1 (Figs 65-66) seems to be related to $C$. peregrinella (HERRICH-SCHÄFFER, 1854). Material examined: Dobrogea, Măcin Mountains, Greci, 280 m, 2.IX.1997, genitalia prep. 1991/9/ Kovács, 1 \%, legit \& coll. L. Rákosy; Banat, Băile Herculane, 250 m, 24-25.IX.2019, genitalia prep. 2450/ふ/ Kovács, 1 ठૈ, legit \& coll. S. \& Z. Kovács. Both specimens are worn, externally resemble $C$. peregrinella, the wingspan of the male is $11.5 \mathrm{~mm}$ and $14 \mathrm{~mm}$ of the female, but both with different genitalia comparing with the figures published by Huemer \& Karsholt (2010). By the male the posterior margin of the vinculum differs, where also the lateral process is long (instead of short, humplike). By the female the ventromedial part of segment VIII is sub-ovate (instead of subtriangular) and the anterior emargination of the antrum is weaker. They were collected in low-mountain steppe habitats with granite (Măcin Mountains) and limestone (Băile Herculane) rock formations. However, $C$. peregrinella, as currently known, is restricted to rock formations and alpine scree on limestone from about 1000 to $2500 \mathrm{~m}$ in the southern Alps and the Balkan Peninsula. The sequencing of the DNA suggests cryptic diversity (HUEMER \& KARSHOLT 2010: 258). The latest genetic studies reveal three BINs, but the holotype of $C$. peregrinella, a female which lacks abdomen and the unknown type locality, is currently an irreconcilable hindrance in solving this taxonomic problem (Huemer \& Karsholt 2020: 133). Further studies are necessary to establish if the two Romanian specimens are or not conspecific and similar with those barcoded from Greece, North Macedonia and Slovenia clustered into the BIN BOLD:AAC6818 (HuEMER et al. 2020, supplementary material 2, NJ tree 18).

Caryocolum mucronatella (CHRÉTIEN, 1900) is distributed predominantly in the mountains of southern Europe (HUEMER \& KARSHOLT 2010: 261). In Romania it was recorded from the Măcin Mountains in Dobrogea by WIESER et al. (2000: 69) and omitted from the checklist of the Romanian Gelechiidae by Kovács \& Kovács (2000: 18). First record for Transylvania: Eastern Carpathians, Perşani Mountains, Vârghiş Gorge, 600-900 m, 7.VIII.2010,

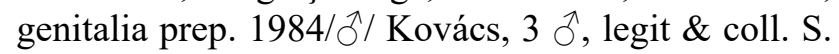
\& Z. Kovács. 
Caryocolum sp.2 (Figs 67-68) is probably an undescribed species, currently under study. Material examined: Dobrogea, Măcin Mountains, Greci, 250 m, 15.VI.2012, genitalia prep. 1997/§/ Kovács, 1 đ; 18.VI.2016, TLMF Lep 27421 and 27422, genitalia prep. 1998/q/ Kovács, 5 q, legit \& coll. S. \& Z. Kovács, coll TLMF, coll. ZMUC. They were attracted to light in a low mountain steppe habitat with granite rock formations and fly together with $C$. alsinella. Two sequenced specimens cluster into a separate BIN (P. Huemer pers. comm.). The genitalia are similar

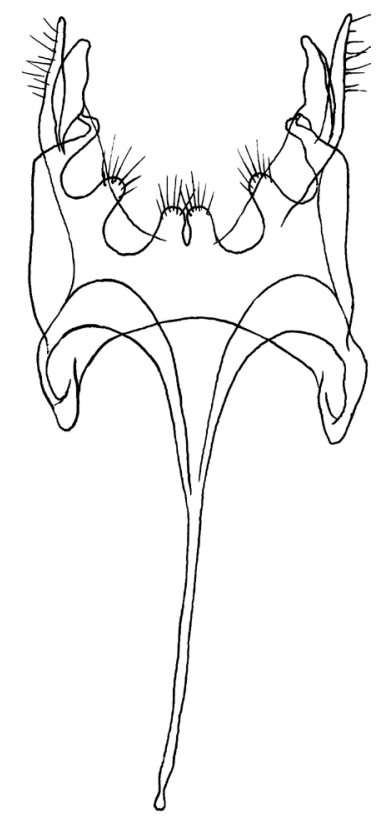

Fig. 65. Caryocolum sp.1: details of free floating male genitalia (vinculo-valvular complex) in ventral view, Banat, Băile Herculane, 250 m, 24-25.IX.2019, genitalia prep. 2450, legit \& coll. S. \& Z. Kovács.

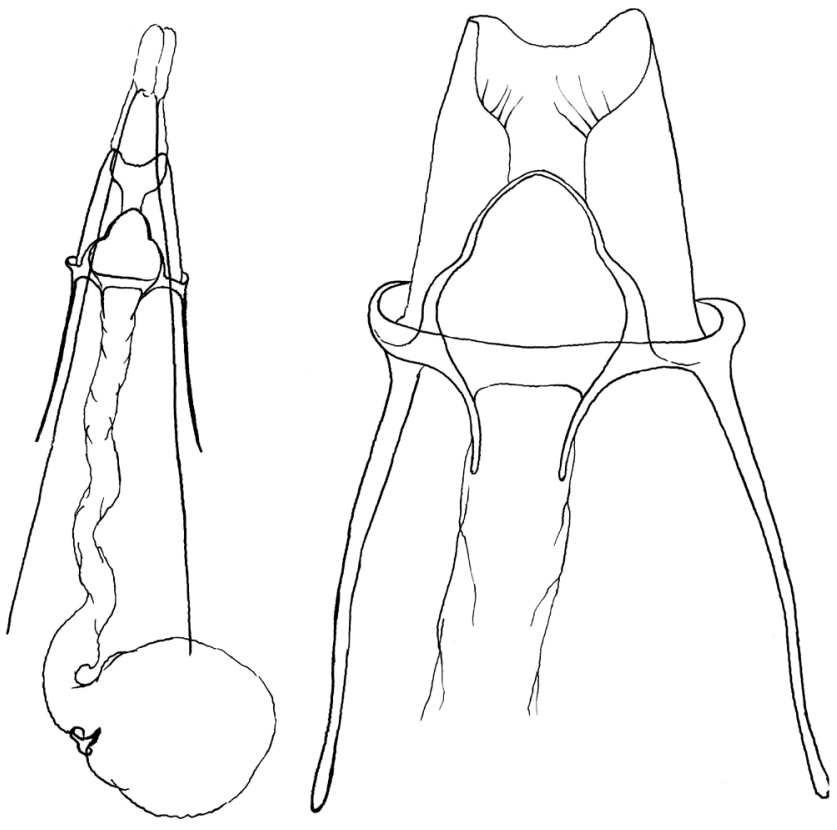

Fig. 66. Caryocolum sp.1: female genitalia (left), enlarged segment VIII and posterior part of ductus bursae (right) in ventral view, Dobrogea, Măcin Mountains, Greci, 280 m, 2.IX.1997, genitalia prep. 1991, legit \& coll. L. Rákosy. with that of specimens bread from Cerastium sp. in Greece by O. Karsholt, but not yet barcoded (O. KARSHOLT pers. comm.), which were published as $C$. mucronatella by HuEMER \& KARSHOLt (2010: 261).

Caryocolum leucomelanella (ZELLER, 1839) is distributed in southern and central Europe, Turkey and China (Huemer \& Karsholt 2010: 261). In Europe two BINs are known without geographical separation (HUEMER \& KARSHOLT 2020: 133). In Romania it was recorded from Transylvania (REBEL 1908: 80; Czekelius 1909: 163), Banat (Rebel 1911: 412) and Moldova (PopesCu-GorJ \& Nemeş 1965: 158; NeMEŞ \& DĂNILĂ 1970: 183). In the checklist of the Romanian Microlepidoptera (POPESCU-GoRJ 1984: 129) it was listed as a synonym of C. vicinella. Recently it was collected from the Apuseni Mountains (Rimetea), Transylvanian Basin (Viişoara) (legit \& coll. S. \& Z. Kovács) and first record for Oltenia:

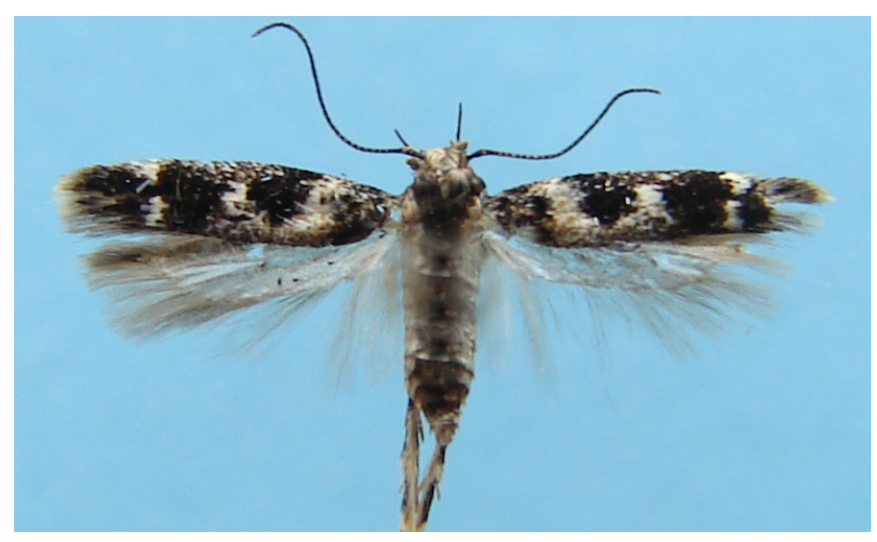

Fig. 67. Caryocolum sp.2: adult, female, wingspan $9.5 \mathrm{~mm}$, Dobrogea, Măcin Mountains, Greci, 250 m, 18.VI.2016, legit \& coll. S. \& Z. Kovács.

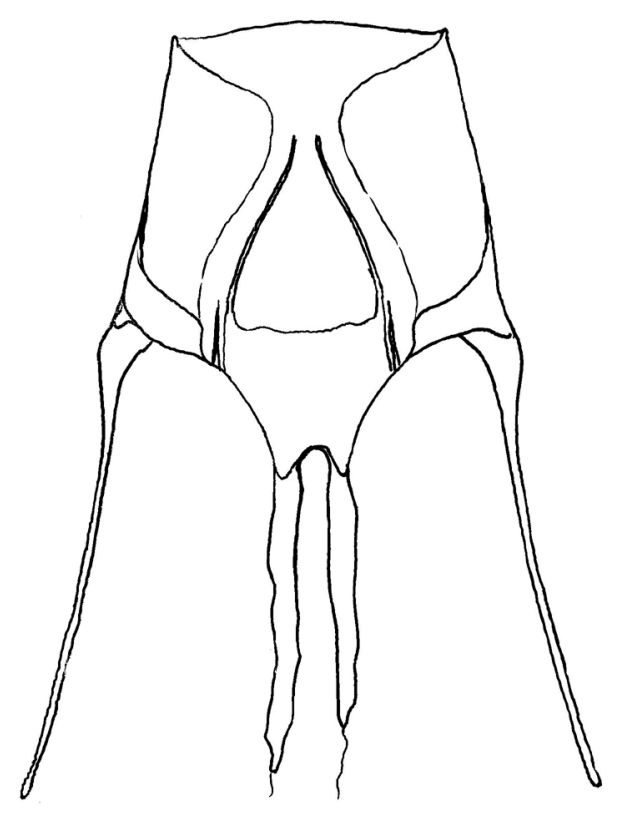

Fig. 68. Caryocolum sp.2: segment VIII and posterior part of ductus bursae of the female genitalia in ventral view, genitalia prep. 1998, same data as Fig. 67. 
Hinova, 150 m, 21.IX.2019, genitalia prep. 2266/§/ Kovács, 3 đ, legit \& coll. S. \& Z. Kovács. Material collected in Romania has not yet been genetically examined.

Caryocolum schleichi (CHRISTOPH, 1872) is distributed in south-western Russia, Turkey and Syria. From the rest of the Near East and the Middle East there are only unconfirmed records. A recent study reveals that the $C$. schleichi species-group currently includes seven species and the unconfirmed records of C. schleichi known from the Near East and Middle East are further putative undescribed species (Huemer 2020: 43). In Romania it was recorded from the Apuseni Mountains (Turda Gorge, 30.V.1986, genitalia prep. 994/\&/ Kovács, 1 q, legit \& coll. S. \& Z. Kovács) by Kovács \& Kovícs (2000: 35). To the same specimen refers also RÁKosy (2002: 67). More recent data are not available. Material collected in Romania has not yet been genetically examined. In the light of the study of HUEMER (2020) it is clear that the taxonomic re-assessment of the Romanian population is inevitable.

Caryocolum pullatella (TENGSTRÖM, 1848) (Figs 69-70) is Holarctic in distribution according to the current species concept, in Europe distributed mainly in the northern parts of the continent and in the Alps (Huemer \& Karsholt 2010: 269). The genetic data indicate cryptic diversity in both the Palaearctic and North American populations (HUEMER et al. 2018: 12), in Europe with two geographically separated BINs, one from Finland (the type locality), Norway and Russia (Altai Republic) and the other from southern and central Europe (HUEMER \& KARSHOLT 2020: 133; BOLD Systems, accessed 7 January 2021; ŠumPICH et al. 2020: 73). First record for the Romanian fauna: Eastern Carpathians, Ciuc Mountains, Fagul Rotund, 18-19.VIII.2000,

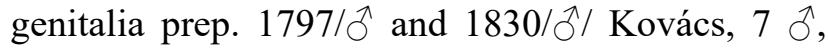
legit \& coll. S. \& Z. Kovács. It is the first record of the species from the Carpathians, a record of great zoogeographical importance. The sequencing of a Romanian specimen failed. Further studies are necessary to establish its correct taxonomic status.

Caryocolum klosi (ReBel, 1917) was recorded from Romania only once based on the following material: Retezat Mountains, 2000 m, 10-23.VII.1914, 2 ${ }^{\lambda}, 1$ q, legit J. Újhelyi; Retezat Mountains, Judele, 1800 m, 4.VIII.1927, 1 ㅇ, legit L. Diószeghy, all coll. HNHM (GoZMÁNY 1953: 184). The species is known only from scattered localities in the Alps (France, Italy, Austria, Germany) and the Czech Republic, the Romanian record was considered doubtful (HUEMER \& KARSHOLT 2010: 274). Its presence in Romania needs confirmation.

Caryocolum proxima (HAWORTH, 1828) is widely distributed in Europe and the Near East (Huemer \& KARSHOLT 2010: 280). It is widespread but underrecorded in Romania, mentioned only from Băile Herculane (ABAFI-Aigner et al. 1896: 69), Sibiu (Czekelius 1905: 82), Mehadia (Rebel 1911: 412, as Lita maculiferella DGL.), Ineu and the Retezat Mountains (KovÁcs \& Kovícs 2001: 97). The record for Dobrogea in RÁkosy et al. (2003: 67) has been based on the until now unpublished field records from Canaraua Fetii(12-13.VII.1993, genitaliaprep. 995/O/ Kovács, 10 o , legit \& coll. S. \& Z. Kovács) and the Măcin Mountains (Greci, 150-200 m, 10.VIII.2001, genitalia prep. 2005/q/ Kovács, 2 q, legit \& coll. S. \& Z. Kovács). It is common in Dobrogea (collected also in Vama Veche and Dumbrăveni), but present also in the southern part of the Eastern Carpathians (Mestecănişul de la Reci).

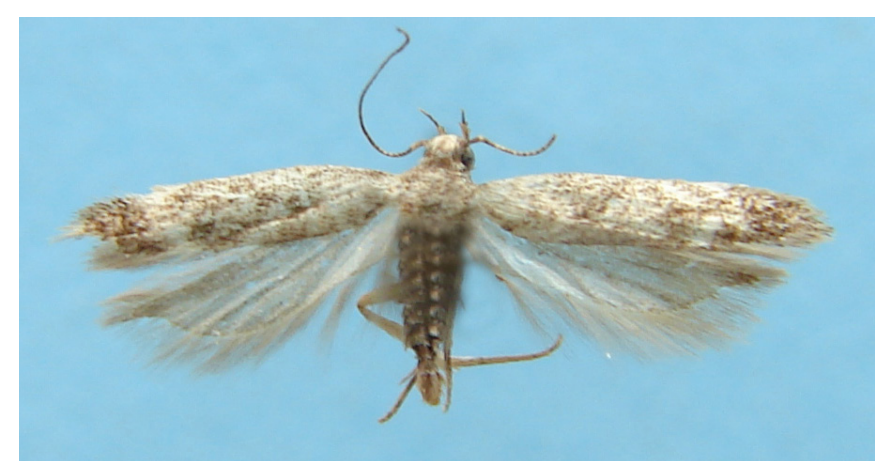

Fig. 69. Caryocolum pullatella (TENGSTRöM, 1848): adult, male, wingspan $11 \mathrm{~mm}$, Eastern Carpathians, Ciuc Mountains, Fagul Rotund, 18-19.VIII.2000, legit \& coll. S. \& Z. Kovács.

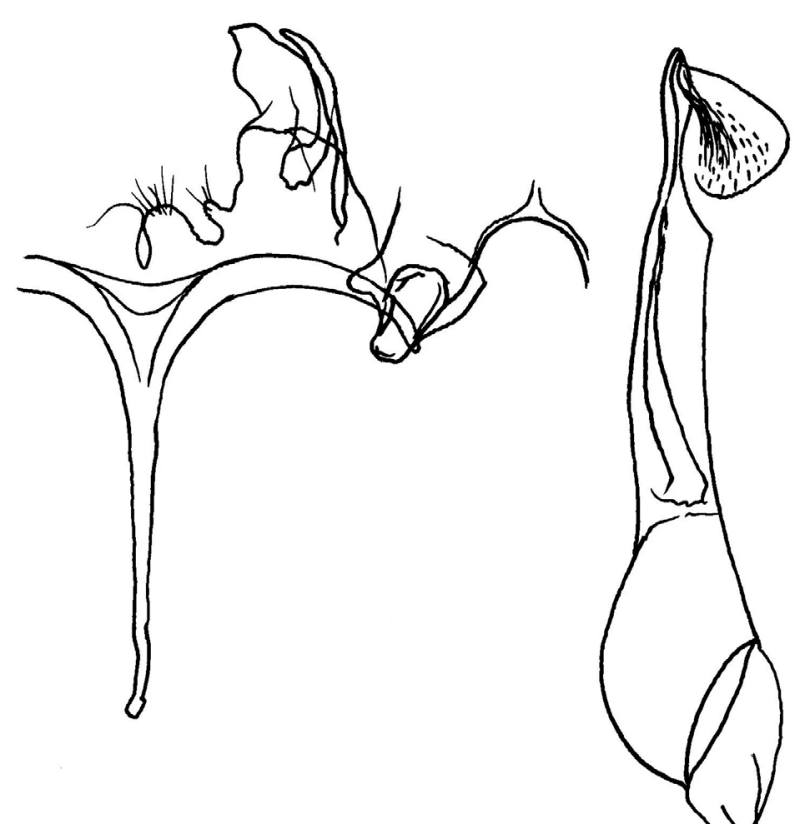

Fig. 70. Caryocolum pullatella (TENGSTRÖM, 1848): details of unrolled male genitalia (part of vinculo-valvular complex and of tegumen, phallus), genitalia prep. 1797, same data as Fig. 69. 
Caryocolum blandulella (TUTT, 1887) (Figs 71-72) is widely distributed in Europe (HuEMER \& KARSHOLt 2010: 281). First record for the Romanian fauna: Dobrogea, Casimcei Plateau, Dobrogei Gorge, 16.VII.2010, 3 Oे, 5 o ; 20.VI.2016, genitalia prep. 2010/ふ/ Kovács, 2 ภ, 2 ๆ; Eastern Carpathians, Baraolt Mountains, Ariuşd, Csókás, 13.XI.2011, genitalia prep. 1749/o/ Kovács, 1 \%, legit \& coll. S. \& Z. Kovács. All were attracted to light.

Caryocolum tricolorella (HAWORTH, 1812) is a European species (HuEMER \& KARSHOLT 2010: 283). From Romania there are old data from Moldova (CARADJA 1899: 204) and Transylvania (REBEL 1908: 79; CzeKelius 1909: 163), recently it was collected only from the southern part of the Eastern Carpathians

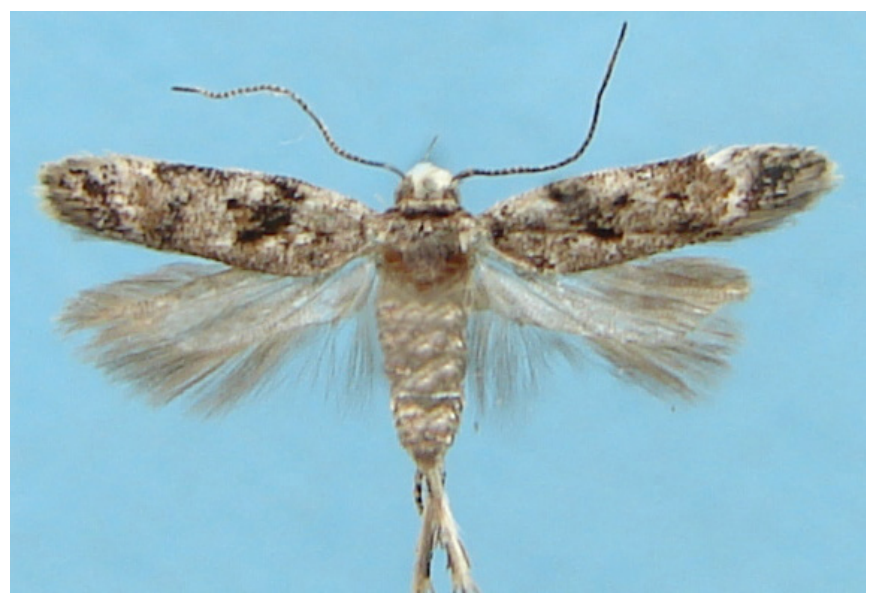

Fig. 71. Caryocolum blandulella (TuTT, 1887): adult, male, wingspan $9 \mathrm{~mm}$, Dobrogea, Casimcei Plateau, Dobrogei Gorge, 20.VI.2016, legit \& coll. S. \& Z. Kovács.

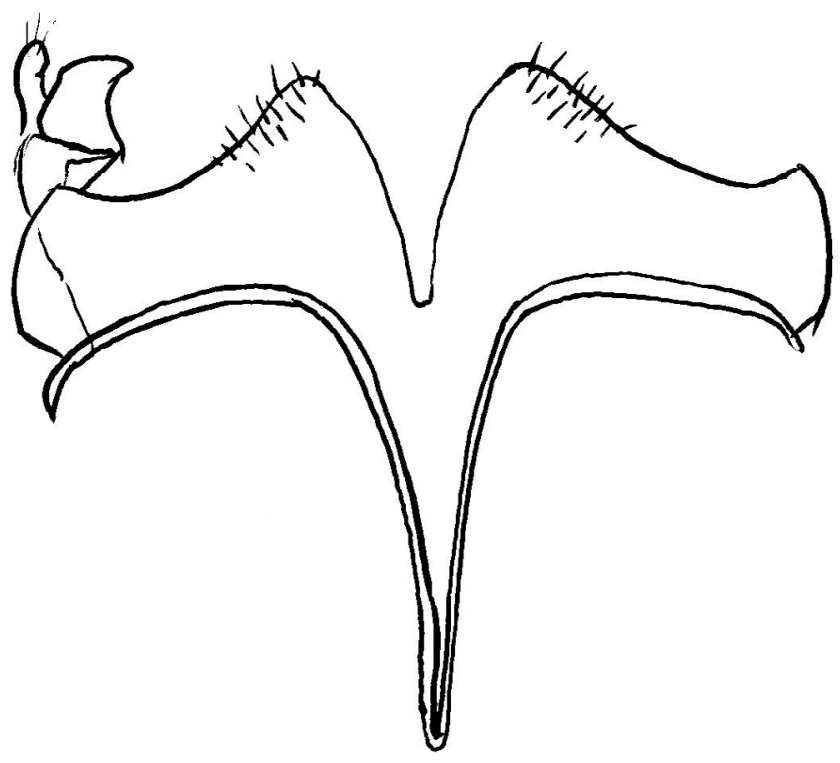

Fig. 72. Caryocolum blandulella (TUTT, 1887): details of free floating male genitalia (part of vinculo-valvular complex) in ventral view, Dobrogea, Casimcei Plateau, Dobrogei Gorge, 16.VII.2010, genitalia prep. 2003, legit \& coll. S. \& Z. Kovács.
(Baraolt, Perşani, Harghita, Ciuc Mountains) and the Transylvanian Basin (Glodeni) (legit \& coll. S. \& Z. Kovács).

Caryocolum junctella (Douglas, 1851) is widely distributed in northern and central parts of the Palaearctic region, it is the only species of the genus known to hibernate as an adult (HUEMER \& KARSHOLT 2010: 285-286). In Europe two BINs without geographical separation (HUEMER \& KARSHOLT 2020: 134). In Romania there are old data from Moldova (Hormuzaki 1907: 83; Caradja 1920: 101) and Transylvania (CzeKelius 1918: 45). We collected the species in the Eastern Carpathians from July to September and again in the early spring from the end of March to beginning of May. In the spring during the day adults rest on the trunks of trees on forest edges and lonely trees, but they fly freely around the crowns of trees in the late afternoon sunshine.

Caryocolum cassella (WALKER, 1864) is a Holarctic species, distributed mainly in the northern parts of Europe and in the mountains (HUEMER \& KaRShOLt 2010: 287). There are two genetic clusters, but they are considered conspecific (ŠUMPICH et al. 2020: 68). In Romania it was mentioned for the first time from the Southern Carpathians (Retezat Mountains), based on a single specimen deposited in the L. Diószeghy collection (Kovács \& Kovícs 2000: 35, 2001: 97). Recently it was also collected from the Eastern Carpathians: Ciuc Mountains, Fagul Rotund, 18-19.VIII.2000, genitalia prep. 1764/ふ// Kovács, 7 స̃, 2 क; Harghita Mountains, Băile Tuşnad, 700 m, 13.VI.2013, 1 Oૈ, legit \& coll. S. \& Z. Kovács. The recently collected specimens were attracted to light.

Caryocolum huebneri (HAWORTH, 1828) is known from scattered localities of western and central Europe (HUEMER \& KARSHOLT 2010: 289). In Romania it was mentioned only from Transylvania (Rebel 1908: 79; CzeKelius 1909: 163). Recently it was collected from the Eastern Carpathians (Bodoc Mountains, Mestecănişul de la Reci) and the Transylvanian Basin (Lechinţa) (legit \& coll. S. \& Z. Kovács).

\section{Caryocolum kroesmanniella (HERRICH-} SCHÄFFER, 1854) was recorded in scattered localities of the northern and central parts of Europe (HUEMER \& KARSHOLT 2010: 290). In Romania it was recorded only from the Eastern Carpathians (Baraolt and Bodoc Mountains) by Kovács \& Kovács (2000: 35). Currently we collected it also from the Harghita and Perşani Mountains in the Eastern Carpathians, and Glodeni in the Transylvanian Basin (legit \& coll. S. $\&$ Z. Kovács). It seems to be more frequent than $C$. huebneri.

Agonochaetia PovolnÝ, 1965 is distributed in the Holarctic region. It was recently revised; nine 
species were recognized, all with unknown hostplants. The seven Palaearctic species were collected in xerothermic steppe habitats. In Europe three species are known (LANDRY et al. 2017); only one was recorded from Romania.

Agonochaetia terrestrella (ZELLER, 1872) was only known from south-eastern Switzerland and Albania, but recently it was recorded and figured from Romania by HuEMER \& KARSHOLT (2010: 296, plate 19, fig. 199c) and later by LANDRY et al. (2017: 470, fig. 11). However, the Romanian specimen clusters into a separate BIN (BOLD:ABV4431) (Huemer \& Karsholt 2020: 134; Huemer et al. 2020, supplementary material 2, NJ tree 3) to $2.41 \%$ p-distance from those from Switzerland (BOLD:ADR8615) (BOLD Systems, accessed 13 December 2020) and may represent a different species, probably A. quartana PovolNÝ, 1990, described from Slivno (= Sliven) in Bulgaria based on a single female (PovolnÝ 2002: 105). All the above mentioned publications refer to a unique specimen collected in Dobrogea, Băneasa, Rezervaţia Canaraua Fetii, 17.V.1997, genitalia prep. 1095/O/ Kovács (identified as $A$. quartana, re-examined as GU 04/1216 $q$ by Huemer and identified as A. terrestrella), 1 , , legit \& coll. S. \& Z. Kovács. We attracted it to light, the collecting site was an exposed oak-forest edge at low altitude covered with steppe vegetation and surrounded with both ruderal herb communities and agricultural fields. Very recently another externally similar specimen was collected during the day in a valley surrounded with both natural (mixed forest and riverine vegetation) and ruderal herb communities in the Apuseni Mountains: Gilău Mountains, 750 m, Valea Someșului Rece, 22.VII.2021, 1 §, legit \& coll. S. \& Z. Kovács. It is the first record for Transylvania. Further studies (sequencing and dissecting of the male specimen) are necessary to establish their correct taxonomic status.

Sattleria PovolnÝ, 1965 is a genus restricted to the alpine and subalpine zones of the European mountain systems, 19 species are recognized. Most species occur in the Alps and Pyrenees, a few in the Apennines and in the mountains of the Balkan Peninsula and a single species is known from the Carpathians. The biology of these species is concisely summarized by HUEMER \& KARSHOLT (2010: 298). GozMÁNY (1953: 184) recorded S. pyrenaica (PETRY, 1904) from the Retezat Mountains, which was based on misidentification (see below in the list of the deleted species).

Sattleria dzieduszyckii (NowICKI, 1864) is the only representative of the genus in the Carpathians (Huemer \& Karsholt 2010: 308) from the Tatra in Poland and Slovakia to the Retezat Mountains in the Southern Carpathians. It was recorded from the Bucegi (Rebel 1908: 79; CzeKelius 1909: 162;
Popescu-GorJ 1995: 176; SzÉKelY 1995: 193) and the Retezat Mountains (Diószeghy 1930a: 285; GozmÁny 1953: 184, as S. pyrenaica; ElSNER et al. 1999: Plate 22). One specimen from the Retezat Mountains has been sequenced and clustered into the BIN BOLD:AAV8914 together with a specimen from the Tatra, but to $0.97 \%$ p-distance (HUEMER et al. 2020, supplementary material 2, NJ tree 48; BOLD Systems, accessed 6 December 2020). Recently we collected most often only single specimens in the Bucegi, Făgăraş and Parâng Mountains, they were netted during the day between 1800-2400 m (legit \& coll. S. \& Z. Kovács). The brachypterous female can be collected by turning water on the scarce vegetation (personal observation) or by smoking with a bee smoker, males can also be attracted to light (HuEMER \& KARSHOLT 2010: 309).

Litini BRUAND D'Uzelle, 1859 earlier were known as Teleiodini Piskunov, 1973. The larvae of the tribe have a general tendency to feed on trees, constituting a phylogenetic signal related to larval mode of life at the highest (tribal) level in the Gelechiidae (KARSHOLT et al. 2013: 346). In Europe 73 species, in Romania 32 are known.

Teleiodes SATtLER, 1960 is distributed in the Palaearctic region (HUEMER \& KARSHOLT 1999: 54). Recently a few species of the genus were transferred into Neotelphusa JANSE, 1958 by LeE \& BROWN (2008). Currently 10 species are known in Europe, 5 of them recorded also from Romania.

Teleiodes vulgella ([DENIS \& SCHIFFERMÜLLER], $1775)$ is widely distributed in Europe and Turkey (HUEMER \& KARSHOLT 1999: 54). It is common and widespread also in Romania, first time mentioned from Transylvania (Sibiu) by Czekelius (1900: 153), later recorded from most of the country except Dobrogea, Muntenia and Oltenia (RÁKosy \& GoIA 2021: 56). We examined material collected in Transylvania (Eastern Carpathians, Transylvanian Basin, Apuseni Mountains), Banat (Băile Herculane) and Dobrogea (Lespezi, 18.V.1994, genitalia prep.

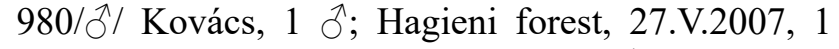
+ , 22.VI.2016, genitalia prep. 1753/§/ Kovács, 2 đ, 3 क; Măcin Mountains, Greci, 15.VI.2012, 1 đ;; 1.VII.2015, 1 q; 18.VI.2016, 1 \%; Canaraua Fetii, 30.V.2014, 1 đ; S Sipote, 31.V.2014, 3 के; Ostrov (flood area of the Danube), 28.VI.2020, 1 q, legit \& coll. S. \& Z. Kovács). Additional studied material is from Muntenia: Breaza (Buzău County), 24.VI.2006, 1 ภ, 1 q, legit \& coll. V. Dincă. There are the first records for Dobrogea and Muntenia.

Teleiodes wagae (NowICKI, 1860) is distributed in the western Palaearctic region, extending eastwards to Siberia (HuEMER \& KarSholt 1999: 58; JunNILAINEN et al. 2010: 30). In Romania it was recorded for the 
first time from the Southern Carpathians (Retezat Mountains) by GozMánY (1953: 183), later from Crişana by Kovács \& Kovács (2001: 93) and also from Banat according to RÁKosY \& GoIA (2021: 56). Recently collected in Transylvania from the Eastern Carpathians (Baraolt, Perşani and Harghita Mountains) and the Transylvanian Basin (Glodeni) (legit \& coll. S. \& Z. Kovács).

Teleiodes saltuum (ZELLER, 1878) is local in northern and widespread across central Europe, recorded also from south-eastern Siberia (HUEMER \& KaRSHOLT 1999: 59), genetically clusters into two BINs (Huemer \& Karsholt 2020: 135). In Romania only two records are known, in the Southern Carpathians from the Retezat Mountains (DiószEGHY 1935: 124) and 3 specimens collected during the day in the Bucegi Mountains (PoPESCU-GorJ 1995: 176). The record from the Retezat Mountains was regarded as doubtful by RÁKosy et al. (2003: 63) and not mentioned by RÁKosY \& GoiA (2021: 56). Voucher material was not available for our study. Material collected in Romania has not yet been genetically examined.

Teleiodes luculella (HÜBNER, 1813) is widely distributed in Europe, extending eastwards to Azerbaijan(HuEMER \& KARSHOLt 1999: 60). In Europe three BINs were recognized (HuEMER \& KARSHOLT 2020: 135). In Romania it is a common and widespread, recorded from the whole country (RÁKOSY \& GoIA 2021: 56). Recent data are from Muntenia (Albu \& Albu 2016: 77), we collected it in Transylvania (Transylvanian Basin, Eastern Carpathians, Apuseni Mountains) and Dobrogea (Canaraua Fetii, Măcin Mountains, Șipote, Dumbrăveni), legit \& coll. S. \& Z. Kovács. Material collected in Romania has not yet been genetically examined.

Teleiodes flavimaculella (HERRICH-SCHÄFFER, 1854) is distributed in most of Europe except the Mediterranean (HUEMER \& KARSHOLT 1999: 61), genetically is variable, with three BINs (HuEMER \& KARSHOLT 2020: 135). The Romanian record was based on a male specimen from Dobrogea (Kovícs \& Kovícs 2002b: 42-43). Later we identified three more specimens from Transylvania: Baraolt Mountains, Sfântu Gheorghe, 650 m, 13.V.1989, 1 q; Trei Scaune Depression, Mestecănișul de la Reci, 17.V.2002, genitalia prep. 2453/ð/ Kovács, 1 ơं; Apuseni Mountains, Metaliferi Mountains, Râmeţ, 1100 m, 11.V.2018, 1 §, legit \& coll. S. \& Z. Kovács. It is the first record for Transylvania. Material collected in Romania has not yet been genetically examined.

Neotelphusa JANSE, 1958, recently LEE \& BROWN (2008) transferred 4 European species from Teleiodes SATTLER, 1960 into this genus. Only one of them is known from Romania.
Neotelphusa sequax (HAWORTH, 1828) is widely distributed in the western Palaearctic region, introduced to North America (HUEmer \& KARSHOLT 1999: 63). In Romania it was mentioned from Dobrogea by MANN (1866: 354), but later was not recorded again from there. It is common and widespread in Transylvania (CzEKELIUs 1909: 162), recorded from the Retezat Mountains (DiószEGHY 1930a: 284; KovÁcs \& Kovícs 2001: 93) and the Eastern Carpathians (SZABÓKY 1994: 349). Recently collected from several sites in the Eastern Carpathians (legit \& coll. S. \& Z. Kovács). It is possibly more widely distributed across the country than currently known.

Carpatolechia CĂPUŞE, 1964 was described based on material collected in Romania (CĂPUŞE 1964: 12). Later it was synonymized with Teleiodes SATTLER, 1960 , but recently removed from synonymy by HuEMER \& Karsholt (1999: 6, 27). In Europe 11 species were recorded (HUEMER \& KARSHOLt 2020: 115), in Romania 7 are known.

Carpatolechia decorella (HAWORTH, 1812) is widely distributed, from the Canary Islands through Europe, North Africa, Turkey and the Middle East to Kazakhstan. It is one of the few Gelechiidae species which are known to hibernate as an adult (Huemer \& Karsholt 1999: 68), in early spring (already from February) adults rest on the trunks of trees of deciduous forest edges. CĂPUŞE (1964: 13) also described Carpatolechia dumitrescui CĂPUŞE, 1964 based on a unique male collected in a cave at 22.I.1958 in the Perşani Mountains (Vârghiş Gorge) (incorrectly located in the Harghita Mountains in the original description), which later was synonymized with Teleiodes decorella. In Romania $C$. decorella was mentioned from Dobrogea by MANN (1866: 353), Transylvania (Czekelıus 1909: 163; CĂPUŞE op. cit.) and Crişana (Kovács \& Kovács 2001: 93). Recently it was collected from Banat (Băile Herculane, Dubova) and several sites in the Eastern Carpathians (legit \& coll. S. \& Z. Kovács). It is possibly more widely distributed across the country than currently known.

Carpatolechia aenigma (SATTLER, 1983) is distributed in southern, central and eastern Europe (HUEMER \& Karsholt 1999: 68). In Romania it was mentioned for the first time from south-eastern Dobrogea (Esichioi forest) and Oltenia (Ostrovul Mare) by POPESCU-GorJ (1985a: 111). Wieser et al. (2000: 32) recorded it from north-western Dobrogea (Măcin Mountains). The symbol representing a Transylvanian record in RÁKosY \& GoIA (2021: $56,215)$ is only an error and must be deleted. One specimen from Romania (Dobrogea, Șipotele, legit C. Wieser, coll. LMKK) was sequenced (HUEMER et al. 2020, supplementary material 2, NJ tree 17 ; BOLD SySTEMS, accessed 18 September 2021). We examined 
material from Dobrogea (Canaraua Fetii, Măcin Mountains), legit \& coll. S. \& Z. Kovács.

Carpatolechia fugitivella (ZELLER, 1839) is widely distributed in Europe, Turkey, the Ural Mountains, the Caucasus, Siberia, Mongolia, Korea and the Far East (Huemer \& Karsholt 1999: 69; JUNNILAINEN et al. 2010: 31). In Romania it seems to be widely distributed, but recorded only from Banat (HedemanN 1897: 30; Rebel 1911: 412), Transylvania (Czekelius 1900: 153; Diószeghy 1935: 124), Moldova (CARAdja 1899: 204; NemeŞ \& DĂNILĂ 1970: 185; RÁKosY et al. 1998: 20) and Muntenia RÁKosY \& Goia (2021: 56). We examined material from Transylvania (Eastern Carpathians, Transylvanian Basin) and Dobrogea (Canaraua Fetii, 16.IX.2004, 1 +; Măcin Mountains, Pricopan Peak, 27-28.V.1994, 1 q; Greci, 26.V.2007, 2 ô, 1 o , legit \& coll. S. \& Z. Kovács). The specimens were attracted to light. It is the first record for Dobrogea.

Carpatolechia fugacella (ZELLER, 1839) is widely distributed in the temperate Europe (HuEMER \& KARSHOLT 1999: 70). Widespread across Romania, recorded from Moldova (CARADJA 1899: 204), Crişana (KovÁCs \& KovÁcs 2001: 93), Transylvania, Muntenia and Dobrogea RÁKosy \& GoIA (2021: 56). We examined material from Transylvania, Dobrogea, Oltenia (Craiova, 20.VII.1989, 1 ऽ, light trap, coll. S. \& Z. Kovács) and Banat (Băile Herculane, $250 \mathrm{~m}$, 16.VI.2021, 2 đ), legit \& coll. S. \& Z. Kovács. There are the first records for Oltenia and Banat.

Carpatolechia alburnella (ZELLER, 1839) is distributed in the northern and central part of Europe, extending eastwards to Siberia and Mongolia (HUEMER \& KARSHOLT 1999: 72). In Romania it was recorded only in Transylvania from Sibiu (CzEKELIUs 1918: 45) and the Retezat Mountains (GozMÁNy 1953: 183). In the Eastern Carpathians it is common between 500 and $1000 \mathrm{~m}$ from the end of June to the beginning of August. Adults, locally in large number, rest during the day on the trunks of old Betula trees, the hostplant of the species, and can easily be disturbed from there.

Carpatolechia notatella (HÜBNER, 1813) is widely distributed in Europe except the Mediterranean (HUEMER \& KARSHOLT 1999: 73). In Romania it was recorded only from the Retezat Mountains (Czekelius 1918: 45; CĂpuşe \& Kovács 1987: 59; Kovács \& Kovács 2001: 94). Recently it was collected from the Eastern Carpathians (Harghita Mountains, Ciuc Depression, Bicaz Gorge), legit \& coll. S. \& Z. Kovács. The symbol for Crişana must be deleted in RÁkosY \& GoIA (2021: 56), because in the L. Diószeghy collection there are specimens only from the Retezat Mountains (see above).
Carpatolechia proximella (HÜBNER, 1796) is Palaearctic in distribution (HUEMER \& KARSHOLT 1999: 73). In Romania first time mentioned from Moldova (CARADJA 1899: 204), later recorded from most of the country except Banat, Dobrogea and Oltenia (RÁKosy \& Goia 2021: 56). Data from the Noroieni forest and Mujdeni (ARDELEAN 1998: 169) are doubtful. We collected the species in the Eastern Carpathians between 540 and $1100 \mathrm{~m}$, where it is locally common.

Pseudotelphusa JANSE, 1958 was described from South Africa, distributed also in the Holarctic region (HuEMER \& KarShOLt 1999: 76). In Europe 5 species are known (HuEMer \& Karsholt 2020: 116), in Romania 4 were recorded.

Pseudotelphusa scalella (SCOPOLI, 1763) is distributed in Europe and Turkey (Huemer \& KARSHOLT 1999: 77). In Romania it was mentioned for the first time from Moldova (CARADJA 1901: 151), later recorded from the whole country (RÁKOSY \& GoIA 2021: 56). It is widespread from the lowlands to lower altitudes in the mountains. During the day adults rest on the trunks of old Betula and Quercus trees, and can easily be disturbed from there. It was also attracted to light.

Pseudotelphusa istrella (MANN, 1866) is distributed in southern Europe and the Near East (HuEMER \& Karsholt 1999: 78), in central Europe recorded only from Slovakia (ELSNER et al. 1999: 34). This species was described by ManN (1866: 354) based on a male and a female specimen collected in the environs of Tulcea in northern Dobrogea. Later it was recorded from south-eastern Moldova (Gârboavele forest, 6.VI.1978, legit \& coll. M. Brătăşeanu) by SzÉKeLY \& CERNEA (2007: 131). Recently collected from Dobrogea again (Măcin Mountains, Dobrogei Gorge, Canaraua Fetii, Şipote, Dumbrăveni, Lespezi) (legit \& coll. S. \& Z. Kovács). One specimen from Romania (Dobrogea, Șipotele, legit C. Wieser, coll. LMKK) was sequenced (HuEMER et al. 2020, supplementary material 2, NJ tree 45; BOLD Systems, accessed 18 September 2021).

Pseudotelphusa paripunctella (ThUNBERG, 1794) is distributed in Europe, extending eastwards to Siberia (HuEMER \& KARSHOLT 1999: 81). In Romania it was recorded for the first time from Dobrogea (MANN 1866: 355), later mentioned from most of the country except Oltenia (RÁKosY \& GoIA 2021: 57). We collected single specimens in warm and dry meadows, forest edges in the Transylvanian Basin, and at lower altitudes in the Eastern Carpathians (up to $1200 \mathrm{~m}$ in Bicaz Gorge) and the Apuseni Mountains. They were netted during the day or attracted to light.

Pseudotelphusa tessella (Linnaeus, 1758) is 
distributed in southern Europe and in scattered localities in central Europe (Huemer \& Karsholt 1999: 82). In Romania it was recorded only once from Mehadia (1859, legit \& coll. J. Mann) by ReBEL (1911: 412).

Istrianis MEYRICK, 1918, recently the world fauna of the genus was partially revised, 21 species were recognized, 15 of them in the Palaearctic region (BIDZILYA \& KarSholt 2015). Since then only a single species was described from Russia (Buryatia) (BIDZILYA \& NuPPONEN 2018: 385). In Europe 7 species are known, in Romania only one.

Istrianis myricariella (FREY, 1870) is distributed in Portugal, Spain, France, Italy, Germany, Switzerland, Greece and North Africa (BIDZILYA \& KARSHOLT 2015: 409). In Romania it was recorded only from the Apuseni Mountains (10 specimens attracted to light in Râmeț between 25.VII and 19.VIII) by VICOL (2002: 127). Only one more specimen was found from the Transylvanin Basin: Glodeni, 24.V.2003, 1 q, legit \& coll. S. \& Z. Kovács. It is a characteristic species of the mountain river banks with Myricaria germanica (L.) Desv., one of the host-plants of the species. In southern Europe and North Africa it was found mainly in coastal habitats, hosted by Tamarix species (Huemer \& Karsholt 1999: 85). The moth can be expected to occur also along the Black Sea coast.

Streyella JANSE, 1958 was described from South Africa, two species from the northern Hemisphere (one from the Canary Islands and another from the southern parts of the Palaearctic region) were transferred later into the genus (HUEMER \& KARSHOLT 1999: 87). In Romania one species was recorded.

Streyella anguinella (HERRICH-SCHÄFFER, 1861) is known from scattered localities in Europe (Spain, Greece, Hungary and Russia), North Africa, Turkey and Lebanon (HuEMER \& KARSHOlT 1999: 87). In Romania it was recorded only from the Black Sea coastal zone (Cetatea Histria, Vadu) by Kovács \& Kovícs (2002b: 43). Later one more collecting site became known from the same area (Jurilovca, legit \& coll. S. \& Z. Kovács).

Teleiopsis SATTLER, 1960 is Holarctic in distribution (HuEMER \& KARSHOLt 1999: 89). In Europe 10 species were recorded (HUEMER \& KARSHOLt 2020: 117), in Romania 4 are known. Considering the ecological preferences of the species an altitudinal delimitation can be observed in Romania: two species are restricted to low mountain habitats, $T$. terebinthinella up to 250 $\mathrm{m}$ and $T$. diffinis up to $800 \mathrm{~m}, T$. laetitiae occurs in the medium-high mountain zone (1100-1800 m) and T. bagriotella inhabits the subalpine region of the Carpathians (see below).
Teleiopsis terebinthinella (HERRICH-SCHÄFFER, 1856) is distributed in the southern and southeastern Europe, Turkey and the Near East (HuEmER \& KARSHOLT 1999: 90). In Romania it is known only from single specimens collected in Dobrogean sites: Canaraua Fetii (Popescu-GorJ 1985a: 112, fig. 8; PitKin 1988: 162; SzÉKely \& Cernea 2007: 132) and the Măcin Mountains (WIESER et al. 2000: 33). The species is restricted to the south-eastern part of the country.

Teleiopsis diffinis (HAWORTH, 1828) is widely distributed in Europe, recorded also from North Africa, south-western and central Asia, Israel (HuEmer \& KARSHOLT 1999: 91; BIDZILYA et al. 2019a: 60). This appears to be the most common and widespread species of the genus in Romania. It can be found at low altitudes up to $800 \mathrm{~m}$, often in large number in sites where the larval host-plants, different Rumex species are most abundant. Despite its wide distribution it was recorded only from Moldova (CARADJA 1899: 203; Nemeş \& DĂNILĂ 1970: 185), Transylvania (Czekelius 1909: 162), Dobrogea (WIESER et al. 2000: 33; SzÉKelY \& CERNEA 2007: 132) and Crişana (Kovács \& Kovács 2001: 94). Data from Turulung (ARDELEAN 1998: 169) are doubtful. First record for Oltenia: Batoţi, 14.V.2016, 3 đૈ; Hinova, 21.IX.2019, 2 3 , legit \& coll. S. \& Z. Kovács. One sequenced specimen from Bărăi (Cluj County) clusters into Teleiopsis diffinis B (BOLD:ACE6105) together with specimens from Austria, Finland, Italy and Norway (HUEMER et al. 2020, supplementary material 2, NJ tree 53; BOLD Systems, accessed 7 January 2021).

Teleiopsis bagriotella (DUPONCHEL, 1840) is recorded from the mountains of Europe and Turkey (HuEMER \& Karsholt 1999: 92), the sequenced specimens clustered into two BINs (HuEMER et al. 2020, supplementary material 2 , NJ tree 53). In Romania it was recorded for the first time from the Bucegi Mountains by Kovács \& Kovács (1994: 37). Following PITKIN (1988) the Romanian records were divided into a "typical form" and a "southeastern form” by Kovács \& KovÁcs (2000: 27). Recently the "southeastern form" was raised to species rank by Schmid (2011: 273) and described as Teleiopsis laetitiae Schmid, 2011 (see below). Currently only the specimens of the "typical form" recorded from the subalpine zone of the Bucegi Mountains belong to $T$. bagriotella. Additional specimens were collected later from the Făgăraş Mountains (Muchia Buteanului, 1800-2000 m, 8.VIII.2013, 4 ठ, 1 ᄋ; Iezerul Caprei, 2000 m, 21.VII.2015, 2 o, legit \& coll. S. \& Z. Kovács). They were collected at altitudes between 1600 and $2000 \mathrm{~m}$ in the daytime by sweeping the low vegetation or attracted to light. All other records from various sites at lower altitudes (presented in details below) belong to $T$. laetitiae, including that from Maramureş by STĂNESCU \& RUŞTI (1997: 96). 
It is the first record for Transylvania as the earlier published data from the Eastern Carpathians (Kovács \& KovÁcs 2000: 27) refer to the following species. The Carpathian specimens differ from those from the Alps in the shape of the tergite VIII, whiches posterior part is longer and more pointed (Kovícs \& Kovács 1994: 39). Material collected in Romania has not yet been genetically examined.

Teleiopsis laetitiae SCHMID, 2011 (Figs 73-74) is a recently described species distributed in Europe and Turkey (Schmid 2011: 275). First record for the Romanian fauna: Eastern Carpathians, Bicaz Gorge, 11-12.VIII.1988, 1 ô; 7-9.VIII.1989, genitalia prep. 858/ふ/ Kovács, 3 ふૈ, 1 †; 26-27.VIII.1989, genitalia prep. 857/ठ̋/ Kovács, 2 ठ̊; 3.VIII.1991, 1 \%; 24.VI.2007, 19; Harghita Mountains, Lacul Sfânta Ana, 1100 m, 13.VII.1995, 3 ō; Bodoc Mountains, Vârful Bodoc, 1100 m, 20.VII.2000, 11 Õ, 1 q; Ciuc

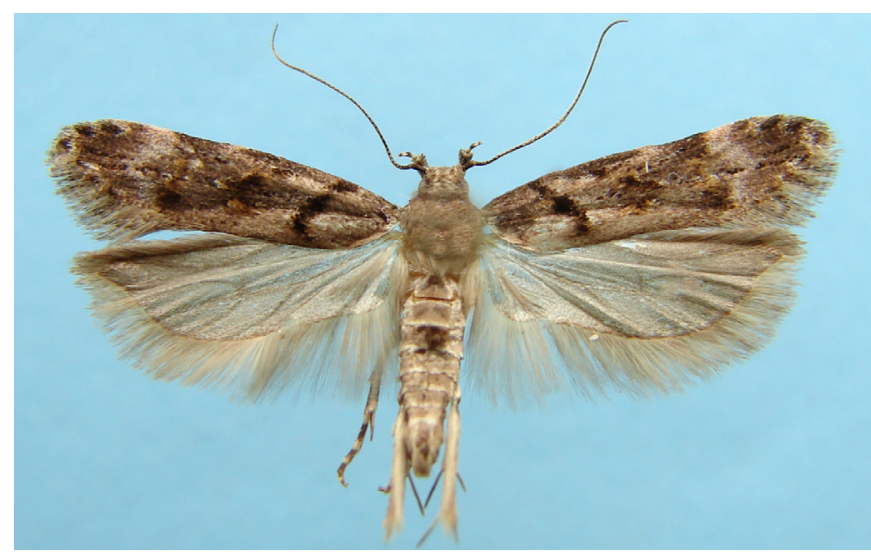

Fig. 73. Teleiopsis laetitiae ScHMID, 2011: adult, male, wingspan $19 \mathrm{~mm}$, Eastern Carpathians, Bodoc Mountains, Vârful Bodoc, 1100 m, 20.VII.2000, legit \& coll. S. \& Z. Kovács.
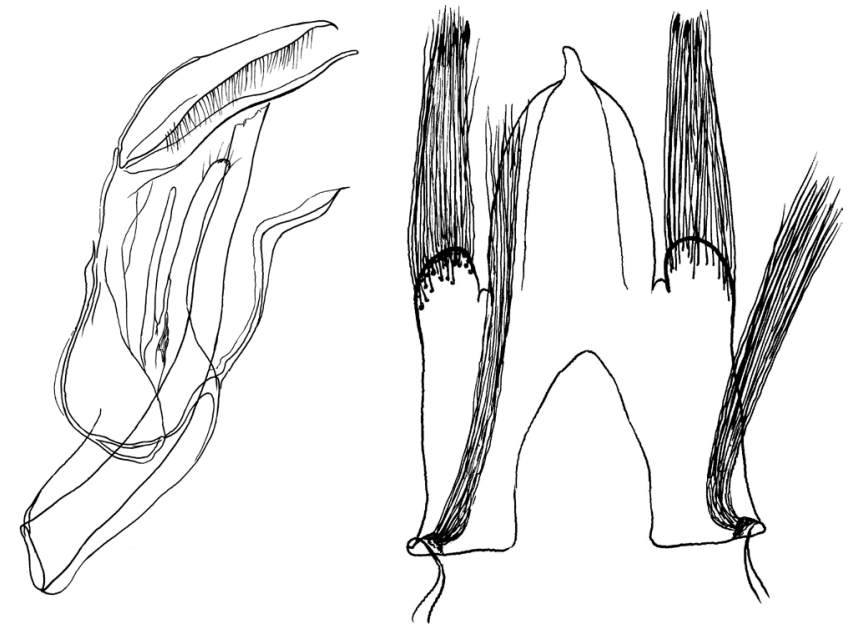

Fig. 74. Teleiopsis laetitiae ScHMID, 2011: free floating male genitalia in lateral view (left), tergite VIII in ventral view (right), Eastern Carpathians, Bicaz Gorge, 7-9. VIII.1989, genitalia prep. 858, legit \& coll. S. \& Z. Kovács.
Mountains, Fagul Rotund, 1300 m, 18-19.VIII.2000, 4 ơ; Harghita Mountains, 1800 m, Vârful Mădăraş, 19.VII.2007, 2 o; Harghita Mountains, Tinovul Mohoş, 21.VI.2008, 1 §ं; Noșcolat Mountains, Vârful Păgânilor, 1250 m, 10.VII.2021, 1 O’, legit \& coll. S. \& Z. Kovács. Earlier this taxon was known as the "southeastern form" of Teleiopsis bagriotella (Duponchel, 1840) (PITKIN 1998: 183) and the Romanian material was published with this name by Kovács \& KovÁcs (2000: 27). We collected it by netting during the day mainly between 1100 and 1800 $\mathrm{m}$ on degraded, overgrazed mountain meadows, where Rumex species are most abundant or attracted to light. A record of T. bagriotella from Maramureş (Pietrosul Rodnei National Park, Laboratory House, 1370 m, 11-12.VII.1995, 5 specimens on light) by STĂNESCU \& RuşTI (1997: 96) may also refer to this species.

Xenolechia Meyrick, 1895 is distributed in the Holarctic region, seven species are recognized, only three in Europe (HuEMER \& KARSHOLt 1999: 95). The European species share DNA barcodes but differ in morphology (HuEMER \& KarSHOLT 2020: 135). In Romania one species was recorded.

Xenolechia aethiops (HUMPHREYS \& WESTWOOD, 1845) (Figs 75-76) is locally distributed in the Holarctic region (HUEMER \& KARSHOLT 1999: 96). First record for the Romanian fauna: Dobrogea, Măcin Mountains, Greci, 150-200 m, 10.VIII.2001, genitalia prep. 1757/ð/ Kovács, 2 ○, 3 + ; 13.IV.2013, genitalia prep. 2039/\&/ Kovács, 2 \&, legit \& coll. S. $\&$ Z. Kovács. The specimens were attracted to light in a xerothermic low mountain meadow.

Altenia Sattlen, 1960 is distributed in the Palaearctic region (HUEMER \& KARSHOLT 1999: 99), with six species in Europe (HUEMER \& Karsholt 2020: 118) and only one in Romania.

Altenia scriptella (HÜBNER, 1796) is distributed in Europe and Turkey (HuEMER \& KARSHOLT 1999: 101). Widely distributed across Romania, recorded from Dobrogea (MANN 1866: 353), Muntenia (CARADJA 1902: 617), Moldova (Nemeş \& DĂNILĂ 1970: 185), Transylvania (Czekelius 1918: 45; Diószeghy 1930a: 284) and Crişana (Kovács \& Kovács 2001: 94). We possess recently collected material from Transylvania, Dobrogea and Banat: Băile Herculane, 250 m, 16.VI.2021, 1 + , legit \& coll. S. \& Z. Kovács. It is the first record for Banat.

Recurvaria HAWORTH, 1828 is Holarctic in distribution, with four species in Europe (HuEMER \& KARSHOLT 1999: 99, 2001: 42) and two from Romania.

Recurvaria nanella ([DENIS \& SCHIFFERMÜLLER], 1775 ) is a pest, larvae feed on Rosaceae. It is distributed in Europe, North Africa, the Near East, Caucasus, 
central Asia and introduced to North America (HuEMER \& Karsholt 1999: 37; JunNILAINEN et al. 2010: 28). In Romania it was recorded from Banat already by HeDEMANN (1897: 30), later mentioned from the whole country (RÁkOSY \& GoIA 2021: 56). Larvae were found on Malus sylvestris Mill., Prunus cerasifera Ehrh., P. domestica L., P. spinosa L. and P. armeniaca L. (DrĂGHIA 1970: 237; 1976: 180). It is widespread and common across lowlands and low mountains, and can be collected mainly attracted to light. We never collected it in large number.

Recurvaria leucatella (CLERCK, 1759) is distributed in Europe, Turkey, the Caucasus and central Asia (HuEMER \& Karsholt 1999: 37; JunNIlainen et al. 2010: 29). In Romania it was mentioned from Dobrogea already by MANN (1866: 354) and later from the whole country (RÁkosy \& GoIA 2021: 56). It is widespread, but not as common as its congener.

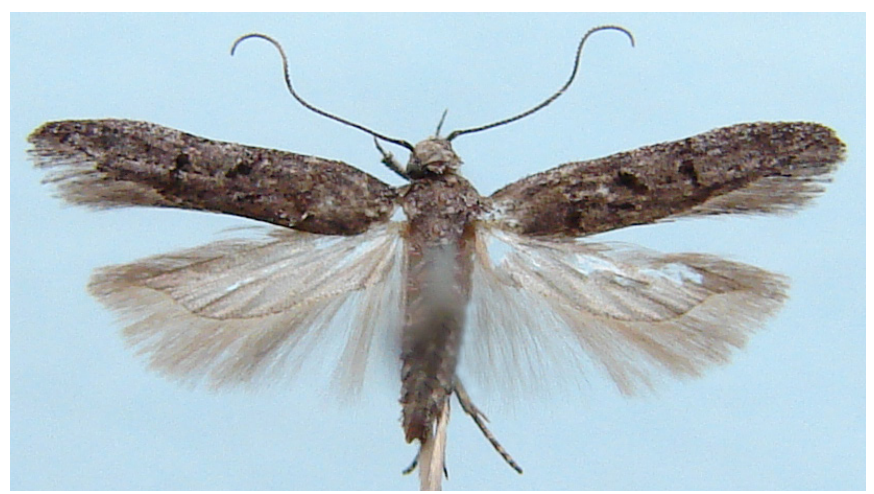

Fig. 75. Xenolechia aethiops (HuMPhreys \& WeSTwood, 1845): adult, female, wingspan $11 \mathrm{~mm}$, Dobrogea, Măcin Mountains, Greci, 150-200 m, 10.VIII.2001, legit \& coll. S. \& Z. Kovács.

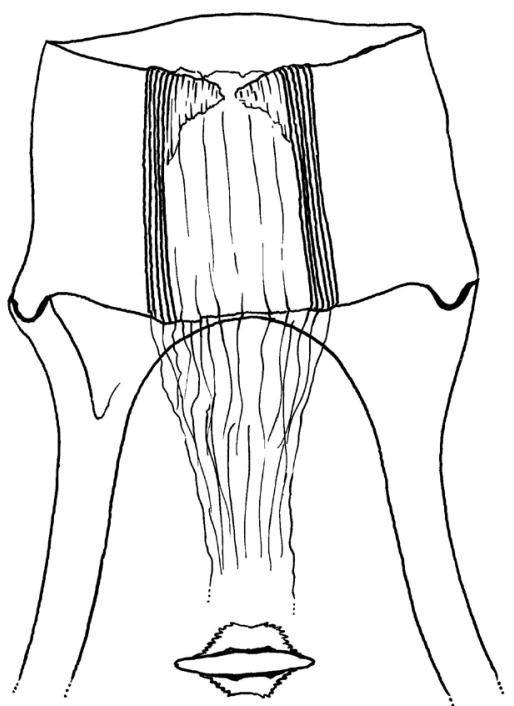

Fig. 76. Xenolechia aethiops (Humphreys \& Westwood, 1845): segment VIII, posterior part of ductus bursae and signum of the female genitalia in ventral view, Dobrogea, Măcin Mountains, Greci, 150-200 m, 13.IV.2013, genitalia prep. 2039 , legit \& coll. S. \& Z. Kovács.
Usually we collected only single specimens, mainly attracted to light.

Exoteleia WALLENGREN, 1881 is a Holarctic genus, with most of the species in North America, only two in Europe (Huemer \& Karsholt 1999: 41) and one in Romania.

Exoteleia dodecella (LinNAEUS, 1758) is distributed in almost all Europe, North Africa, the Caucasus, central Asia and introduced in North America (Huemer \& Karsholt 1999: 42). The dark specimens may represent a different species (HuEMER \& Karsholt 2020: 135). In Romania it was mentioned in Transylvania from Sibiu (Czekelius 1918: 45), known also from Crişana (Kovács \& Kovícs 2001: 93), the Apuseni Mountains (RÁKosY \& WIESER 2010: 53; legit \& coll. S. \& Z. Kovács), the Eastern Carpathians and the Transylvanian Basin (KovÁcs et al. 2002: 55; legit \& coll. S. \& Z. Kovács). We collected it at light in large number in sites where Pinus sylvestris L. is most abundant (the Mohoş and Luci peat bogs), and only single specimens in sites with Pinus nigra Arn. plantations (Măcin, Baraolt, Gurghiu, Ciuc Mountains, Viişoara, Mestecănișul de la Reci), both pine species known as larval hostplants. First record for Dobrogea: Măcin Mountains, Pricopan Peak, 27-28.V.1994, genitalia prep. 1750/ふ/ Kovács, 1 ठ, legit \& coll. S. \& Z. Kovács. We collected dark specimens only in sites with plantations (Baraolt Mountains, Viişoara). Material collected in Romania has not yet been genetically examined.

Stenolechia Meyrick, 1894 is distributed in the Palaearctic region, with only one species in Europe (Huemer \& Karsholt 1999: 44).

Stenolechia gemmella (LINNAEUS, 1758) is distributed in Europe except the northernmost parts, the Caucasus (Huemer \& KARShOlT 1999: 44), Israel and Jordan (BIDZILYA et al. 2019a: 57). In Romania it was mentioned from Grumăzești in Moldova (CARAdja 1901: 152, as Poecilia nivea Hw.), Transylvania (PopesCu-GorJ 1964: 33; legit \& coll. S. \& Z. Kovács), Oltenia (STĂNoIU \& CHIMIȘLIU 1993: 43) and Dobrogea (RÁkosy \& Goia 2021: 56). We collected it at light on the end of August and September at low altitudes in the Eastern Carpathians (Harghita, Baraolt, Bodoc, Perşani Mountains). First record for Banat: Băile Herculane, $250 \mathrm{~m}, 24-25$. IX.2019, 1 \&, legit \& coll. S. \& Z. Kovács. The record from Moldova was omitted by Rákosy \& GoIA (2021: 56).

Parastenolechia KANAZAWA, 1985 is distributed in the Palaearctic ( 9 species) and Oriental (4 species) regions, with only one species in Europe (PARK \& Ponomarenko 2006: 49). 
Parastenolechia nigrinotella (ZELLER, 1847) is distributed in the central and southern parts of Europe and Turkey, Lebanon and Israel; adults are on the wing in June and July (Huemer \& Karsholt 1999: 46; BiDZILYA et al. 2019a: 57). In Romania it was mentioned for the first time from Banat (REBEL 1911: 413), later from Moldova (Gârboavele forest) (Olaru \& Nemeş 1969: 128) and Oltenia (Ostrovul Mare) (PoPesCu-GorJ 1985a: 111). Recent data are only from Transylvania (RÁKosy \& GoIA 2021: 56) and Dobrogea: Măcin Mountains (WIESER et al. 2000: 32; legit \& coll. S. \& Z. Kovács), Horia (SzÉKelY \& Cernea 2007: 131), Hagieni (legit L. Rákosy, coll. ZMUC), Dobrogei Gorge (legit \& coll. S. \& Z. Kovács). One specimen from Dobrogea (Hagieni, 29.IX.1978) recorded by SzÉKELY \& CERNEA (2007: 131) was misidentified and refers to an unidentified species, which is not a gelechiid moth.

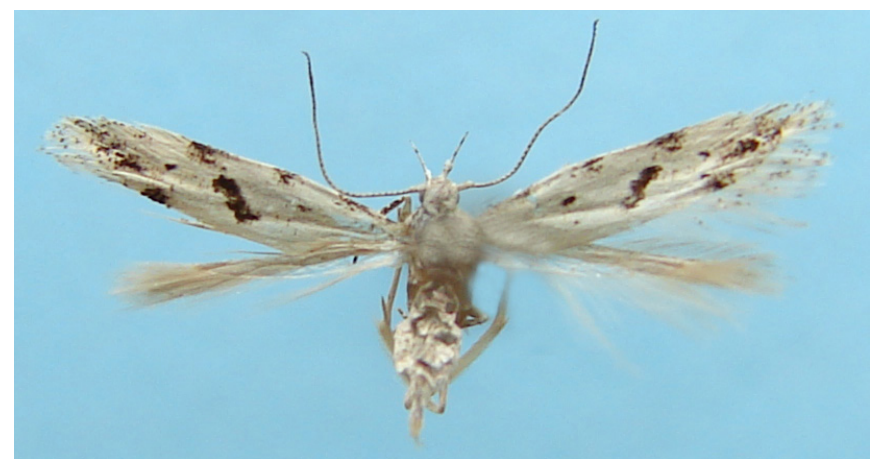

Fig. 77. Stenolechiodes pseudogemmellus ELSNER, 1996: adult, female, wingspan $9.5 \mathrm{~mm}$, Eastern Carpathians, Baraolt Mountains, Sfântu Gheorghe, 13.V.1989, legit \& coll. S. \& Z. Kovács.

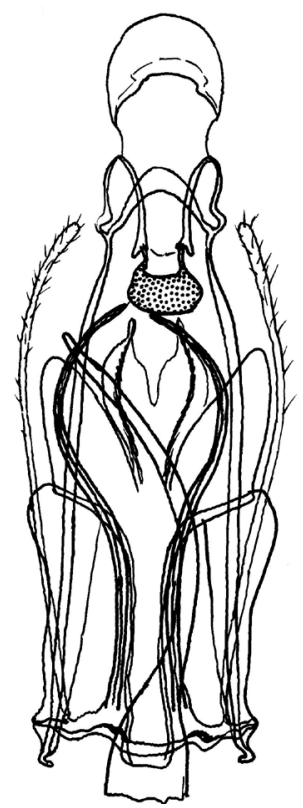

Fig. 78. Stenolechiodes pseudogemmellus ELSNER, 1996: free floating male genitalia in ventral view, Transylvanian Basin, Lechința, 11.V.2002, genitalia prep. 1752, legit \& coll. S. \& Z. Kovács.
Stenolechiodes ELSNER, 1996 is distributed in the western Palaearctic, comprises 2 species (HuEMER \& KARSHOLT 1999: 46, 48), one of them recorded also from Romania.

Stenolechiodes pseudogemmellus ELSNER, 1996 (Figs 77-78) is distributed in central and southeastern Europe, and Turkey; adults are on the wing in two generations in April and May, and then again in July (Huemer \& Karsholt 1999: 47-48). First record for the Romanian fauna: Transylvania, Eastern Carpathians, Baraolt Mountains, Sfântu Gheorghe, 650 m, 13.V.1989, 1 \&; Transylvanian Basin, Lechinţa (Mureş County) 11.V.2002, genitalia prep. 1752/ふ/ Kovács, 1 đ̊; Glodeni (Mureş County), 1.V.2004, 1 +; Dobrogea, Băneasa, Rezervaţia Canaraua Fetii, 12-13.VII.1993, 1 †; Măcin Mountains, Greci, 27.IV.2013, 1 क; 1.VII.2015, 1 o, legit \& coll. S. $\&$ Z. Kovács. The adults of the similar Stenolechia gemmella are on the wing considerably later, from the end of August to the end of September (see above).

Parachronistis MEYRICK, 1925 is distributed in the Palaearctic region, with only one European species (HuEMER \& Karsholt 1999: 49).

Parachronistis albiceps (ZELLER, 1839) is distributed in the Palaearctic region, widespread in Europe, rarely recorded from Asia (HUEMER \& KARSHOLT 1999: 50). In Europe four BINs are known without geographical separation (HUEMER \& KARSHOLT 2020: 135). In Romania it was recorded for the first time from Banat (HEDEMANN 1897: 30), later mentioned from most of the country except Dobrogea and Crișana (RÁkosy \& GoIA 2021: 56). Data from Porumbești (ARDELEAN 1998: 169) are doubtful. We collected single specimens from mid-May to July only in Transylvanian sites. Material collected in Romania has not yet been genetically examined.

\section{Taxa deleted from the Romanian checklist}

A total of 24 species and 2 genera are considered to be recorded in error from the country. Certain misidentification were established by 7 species, by the 2 genera and 12 species there are well-founded arguments that their records were based on incorrect identification, and by 5 species recent studies revealed that the initially recorded taxa must be replaced with others.

Aproaerema larseniella (GozMÁNY, 1957) is distributed in western and northern Europe, locally in central Europe (ELSNER et al. 1999: 51), only recently recorded from Slovakia (ToKÁR et al. 2010: 36). In Romania it was recorded from the Eastern Carpathians (Bicaz Gorge) by Kovács \& Kovács (2000: 37), but the re-examined specimens turned to be $A$. cinctelloides (NeL \& VARENNE, 2012). We delete 
the species herewith from the Romanian checklist.

Dichomeris acuminatus (STAUDINGER, 1876) is distributed in Europe only in the Mediterranean (KARSHOLT 2004-2020, accessed 3 May 2019). In Romania it was mentioned from Cluj (Transylvania) by PeRJu \& PeIU (1986), but its presence was regarded as improbable and has been deleted from the checklist by RÁkosy et al. (2003: 358).

Acompsia minorella ReBEL, 1899 is known from scattered localities in Austria, the Czech Republic, France, Italy, Slovenia and Switzerland (HuEmer \& KARSHOLT 2002: 125). It was mentioned from Romania only by CĂPUŞE \& Kovács (1987: 60) based on a misidentified Acompsia cinerella (CLERCK, 1759) and deleted from the checklist by Kovács \& Kovács (2000: 42).

Helcystogramma albinervis (GERASIMOV, 1929) is very local and recorded in scattered localities in central Europe, but widespread in the southern Ural Mountains (ANIKIN et al. 1999: 320; JUNNILAINEN et al.2010: 65; RIst 2014: 2). In Romania it was recorded from Satu Mare by ARDELEAN (1998: 168) based on two specimens in the I. Szabó collection, which currently are deposited in the MGAB. Their recent re-examination proved that they in fact are Platyedra subcinerea (HAWORTH, 1828) (M. STǍNESCU pers. comm.). Consequently, in the absence of evidence, we exclude it now from the checklist, with the remark that the moth can be expected to occur in Romania.

Pectinophora gossypiella (SAUNDERS, 1844), the Pink Bollworm, is a pest of cotton (Gossypium hirsutum L.) with a large distribution throughout the world, thought to have originated in India. In Europe verified data are only from the southernmost parts of Greece and Spain (BOLD Systems, accessed 7 October 2021). It is mentioned from Romania without any further data in the website of EPPO (2021). In the absence of evidences we exclude it now from the Romanian checklist.

Thiotricha coleella (CONSTANT, 1885) is distributed only in southern France (HUEMER 1993: 55; KARSHOLT 2004-2020, accessed 3 May 2019). In Romania it was mentioned from Ineu (Crişana) by CĂPuşe \& Kovács (1987: 60), the two voucher specimens were examined and identified as T. subocellea (StePhens, 1834) by Kovács \& Kovács (1994: 48). Consequently the species was not accepted for the checklist by Kovács \& Kovács (2000: 21).

Bryotropha plebejella (ZELLER, 1847) is, according to KaRShOLT \& RUtTen (2005: 134), distributed only in the Mediterranean countries. In Romania it was recorded from Dobrogea (Eforie Sud) by CARADJA (1929: 61) and not mentioned later again, but included in the Romanian (POPESCU-GoRJ 1984: 128; KovÁcs \& Kovács 2000: 27; RÁKosy et al. 2003: 63; RÁKosY \& GoIA 2021: 55) and European checklists (KARSHOLT \& RIEDL 1996: 109). The identification was not confirmed with the study of the genitalia and the Romanian collecting site is located far a way from the known range of the species. Considering improbable we exclude it herewith from the Romanian checklist.

Bryotropha umbrosella (ZELLER, 1839) is distributed only in the open dune areas of north-western Europe (KARSHOLT \& RutTEN 2005: 140). In Romania it was mentioned from Moldova (Grumăzeşti) by CARADJA (1901: 151, as mundella) and included in the checklist by POPESCU-GoRJ (1984: 128). Later recorded from Ineu and Aldeşti (Crişana) by CĂPUŞE \& KovÁcs (1987: 59) and from the Noroieni forest (ARDELEAN 1998: 169), all were identified without the examination of the genitalia. The re-examined voucher specimens in the L. Diószeghy collection proved to be Aproaerema anthyllidella, Teleiodes vulgella and Altenia scriptella. The presence of the species in Romania was regarded as improbable and deleted from the checklist already by Kovícs \& Kovács (2000: 25).

Ptycerata furfurella (STAUDINGER, 1871) was described from the southern part of European Russia (Sarepta) and thought to be distributed from southern Europe to Kazakhstan (ELSNER et al. 1999: 21), but recent studies confirmed it only from Russia and western Kazakhstan (BIDZILYA \& KARSHOLT 2021: 159). It was mentioned in Romania from Crişana (Ineu) and the Transylvanian Basin (Viişoara) by Kovács \& KovÁcs (2000: 21, 2001: 89). However, recent molecular and morphological studies revealed that the populations ranging from Austria to Ukraine represent a different species, C. cryptoxena (GozMÁNY, 1952) (Huemer \& Karsholt 2020: 125; Huemer et al. 2020, supplementary material 2, NJ tree 19; BIDZILYA \& KARSHOLT 2021: 166), which replaces $C$. furfurella in the Romanian fauna as well. We remove it herewith from the Romanian checklist.

Isophrictis lineatellus (ZELLER, 1850) is distributed in Europe only in the western Mediterranean and Greece (KARSHOLT 2004-2020, accessed 3 May 2019). In Romania it was recorded from Muntenia (Bucharest) by CARADJA (1899: 204, 1901: 154, as Cleodora), but never mentioned again, neither in the checklists (POPESCU-GoRJ 1984; KARSHOLT \& RIEDL 1996; Kovács \& Kovács 2000; RÁKosY et al. 2003; RÁkosY \& GoIA 2021). We agree with this approach, considering it improbable in Romania.

Oxypteryx nigromaculella (MILLIÈRE, 1872) is distributed in Europe in the Mediterranean and Ukraine (KARSHOLt 2004-2020, accessed 3 May 2019). In 
Romania it was mentioned from Ineu (Crişana) by CĂPuşE \& Kovács (1987: 60, as Caryocolum), but not confirmed and not included in the checklist by Kovács \& Kovács (2000: 14), because the specimen in fact is Caryocolum proxima (HaworTH, 1828) (Kovács \& Kovícs 2001: 97).

Oxypteryx libertinella (ZeLLER, 1872) is distributed throughout the Alps, shows an exceptional intraspecific barcode divergence with geographically separated major haplotypes, and needs revision again (Huemer et al. 2013: 95; Huemer \& Karsholt 2020: 129). The unique record from Romania (Bărăi, Cluj County, legit \& coll. C. Wieser) was mentioned, but not included in the Romanian checklist by RÁKosY \& GoIA (2021: 288, as Eulamprotes). We agree with this approach, because we consider its presence in Romania improbable, the unpublished data of the failed sequencing are also among $O$. wilkella (Linnaeus, 1758) instead of $O$. libertinella in the database of the BOLD Systems (accessed 13 November 2021) and O. wilkella was collected in Transylvanian sites (see above).

Oxypteryx nigritella (ZELLER, 1847) is known only from the Mediterranean islands of Malta, Sardinia, Sicily and the continental Italy (KARSHOLT 2004-2020, accessed 11 February 2019). The unique record from Romania (Băile Herculane, 23.VII.1910) was considered doubtful already by ReBel (1911: 412) himself. We consider it improbable and delete it herewith from the Romanian checklist.

Sophronia chilonella (TREITSCHKE, 1833) is distributed in Europe (ELSNER et al. 1999: 50). In Romania it was mentioned only by CĂPUŞE \& KovÁCs (1987: 61). The voucher specimens in the L. Diószeghy collection were examined and identified as Sophronia grandii Hering, 1933 and S. humerella ([Denis \& Schiffermüller], 1775) (Kovícs \& Kovács 2001: 97). Sophronia chilonella was deleted from the checklist of the Romanian Gelechiidae already by Kovícs \& Kovács (2000: 35).

Mirificarma flavella (DUPONCHEL, 1844) is a Mediterranean species (HUEMER \& KARSHOLT 1999: 129). In Romania it was mentioned from Băile Herculane and Orşova (Banat) by ReBEL (1911: 413) and Cisnădioara (Transylvania) by Czekelıus (1918: 46). In the revision of the genus Mirificarma (PITKIN 1984: 26-29) the species was not mentioned from Romania, however, it was poited out, that specimens of Orophia ferrugella ([DENIS \& SCHIFFERMÜLLER], 1775) (Depressaridae, Cryptolechiinae) were consistently misidentified as $M$. flavella by H. Rebel. Consequently the above mentioned records were considered incorrect and M. flavella was deleted from the checklist of the Romanian Gelechiidae by Kovícs \& Kovícs (2000: 28).
Chionodes nubilella (ZETTERSTEDT, 1839) is restricted to the arctic parts of the Palaearctic region (HUEMER \& Karsholt 1999: 145). In Romania it was recorded from northern Moldova (Suceava, Salcea, Rarău Mountains) by Nemeş \& LungocI (1973: 242), but it was not included in the Romanian checklists (PoPESCU-GoRJ 1984; Kovács \& Kovács 2000; RÁkosy et al. 2003: 356). We agree with this approach, considering it improbable in Romania.

Chionodes nebulosella (HEINEMANN, 1870) was mentioned from Romania by Kovács \& Kovács (2000: 28, fig. 13). The re-examined adult externally resembles $C$. nebulosella, but the female genitalia are close to C. viduella (FABRICIUS, 1794). It is probably an undescribed species, which, considering the lack of material, needs further studies. We exclude herewith C. nebulosella from the checklist and replace it with the formally not yet named Chionodes sp. (see also above).

Scrobipalpa feralella (ZELLER, 1872) is only known from a few localities in Austria, Switzerland and northern Italy (HUEMER \& KARSHOLT 2010: 89). In Romania it was mentioned from the north-western part of the country (Viile Satu Mare) without the study of the genitalia (ARDELEAN 1998: 169, as Chionodes). This record is based on misidentification, the sole specimen from the I. Szabó collection, currently deposited in the MGAB, is not a gelechiid moth (M. STĂNESCU pers. comm.). The species has already been removed from the checklist by RÁkosy \& GoIA (2021: 277, 282) with the presumption that it was misidentified.

Scrobipalpa suaedella (RICHARDSON, 1893) is distributed in coastal habitats from northern Germany through parts of Great Britain and France, also Portugal, Spain, Corsica, Sardinia to Cyprus, Turkey and Lybia (HuEMER \& Karsholt 2010: 131). In Romania it was recorded from the Eastern Carpathians (Chiril in the Rarău Mountains) by PEIU \& Nemeş (1970: 60) without the study of the genitalia. It was included also in the checklist of the Romanian Microlepidoptera by POPESCU-GoRJ (1984: 128, as suadella), and mentioned from Romania without more details by Povolný (2002: 71). This record was considered incorrect, the presence of the species improbable in Romania and has been deleted from the checklist of the Romanian Gelechiidae already by Kovács \& Kovács (2000: 29).

Scrobipalpa stangei (HERING, 1889) is distributed in northern Europe and Central Asia (Huemer \& KaRSHOLT 2010: 141). In Romania it was mentioned by Kovács \& Kovács (2000: 31) based on misidentification, the species was deleted from the checklist and replaced with $S$. salinella (ZELLER, 1847) by RÁKosy et al. (2003: 357). Later the voucher 
material was re-examined by O. Karsholt and proved to be S. salicorniae (Hering, 1889) (Huemer \& KARSHOLt 2010: 141).

Scrobipalpa costella (HUMPHREYS \& WESTWOOD, $1845)$ is distributed only in north-western Europe (HuEMER \& Karsholt 2010: 157). In Romania it was recorded from the Retezat Mountains (DiószEGHY 1930a: 285, as Lita; GozMÁNY 1958: 209), from Ineu in Crişana (Kovács \& Kovács 2000: 33), and mentioned from Romania without more specific location by ELSNER et al. (1999: 44), but based on misidentification of S. hyoscyamella (STAINTON, 1869) (for details see there), which replaced S. costella in the Romanian fauna (Kovács \& KovÁcs 2001: 89, 97; RÁKosY et al. 2003: 258, 357).

Scrobipalpa salinella (ZELLER, 1847) earlier (e.g. PovolNÝ 2002) has been treated as a variable and polyphagous species, with several junior synonyms. In Romania it was mentioned from Gârboavele forest, the Danube Delta (Olaru \& Nemeş 1969: 128), Ineu (legit \& coll. L. Diószeghy) (Kovács \& Kovács 2001: 96), and included also in the checklists (PopescuGORJ 1984: 128; KARSHOLt \& RiEdL 1996; KováCs \& Kovács 2000: 18, 31; RÁkosy et al. 2003: 66; RÁKosY \& GoIA 2021: 58). Recently several taxa previously treated as its junior synonyms have been restored to full species rank based on differences in the external appearance, genitalia morphology and biology (Huemer \& Karsholt 2010). Consequently, 4 of 10 by PovolnÝ (2002: 67) as synonyms of $S$. salinella mentioned taxa currently are treated as distinct species, two of them, S. salicorniae and S. thymelaeae are recognized from Romania. During the present study the available Romanian material considered earlier to be $S$. salinella was re-examined by us and a few selected specimens also by O. Karsholt, and all proved to be $S$. salicorniae, including the record from Ineu (legit \& coll. L. Diószeghy) (Kovács \& Kovács 2001: 96). Taking in account this result and considering that $S$. salinella is distributed only in coastal and inland halophytic habitats of the Mediterranean (HuEMER \& KARSHOLt 2010: 178), we concluded, that S. salinella currently is not part of the Romanian fauna, thus we remove it now from the checklist and replace it with S. salicorniae (see also there).

Ochrodia subdiminutella (STAINTON, 1867) is a member of a genus characteristic for the eremic parts of the Palaearctic, Afrotopical, Australian and Indo-Malayan regions. In Europe it is known from Spain, Malta and Crete. Taxonomically it is one of the most confused Gnorimoschemini species, currently considered a species complex (HUEMER \& KARSHOLT 2010: 222). In Romania it was recorded from Moldova (Agapia, Neamţ County) as new to Europe by Nemeş (1974: 209, as Ephysteris), but neither mentioned again nor included in the checklists (POPESCU-GoRJ
1984; Karsholt \& Riedl 1996; Kovács \& Kovács 2000; RÁKosy et al. 2003: 357). The latter mentioned authors, considering it improbable in Romania, removed it from the checklist.

Sattleria pyrenaica (PETRY, 1904) in Romania it was recorded from the Retezat Mountains by GozMÁNy (1953: 184, 1958: 222). However, later studies revealed that it is an endemic of the HautesPyrenees and the Pyrenees Orientales, and in the entire Carpathians the only representative of the genus is $S$. dzieduszyckii (Nowicki, 1864) (PITKIN \& SATtLer 1991: 216, 223; Huemer \& Karsholt 2010: 301, 308). Considered a misidentification, this species was not mentioned for Romania in the checklists (Popescu-Gorj 1984; Povolný 1996; Kovács \& Kovács 2000; RÁKosy et al. 2003: 357). The latter mentioned authors, considering it improbable in Romania, removed it from the checklist.

\section{Conclusions}

With a total of 293 identified species, Gelechiidae became the best known Microlepidoptera family in the Romanian fauna. Following Tortricidae with 565, Noctuidae with 559 and Geometridae with 480 recorded species, it is the fourth most species rich family of the Romanian Lepidoptera. Since 1984, when the first modern Romanian checklist was published (POPESCU-GorJ 1984), the number of the identified Gelechiidae species raised from 176 to 293, which means that almost $40 \%$ of the currently known species were recorded over the past 36 years.

Until now only about $13 \%$ of the Romanian Gelechiidae was sequenced. In the view of the molecular studies we conclude that in the nature not the variability within the species is the norm, as it was believed until recently, but the high level of diversity. Following the latest results of the molecular studies became obvious that the diversity within the European Gelechiidae was highly underestimated and this statement is valid to the Romanian fauna too. We already mentioned the presence of 7 probably undescribed species in the Romanian fauna, 5 of them are confirmed also by genetic studies, and, if further DNA sequencing will be possible, this number may increase spectacularly.

Over the last two decades significant changes have taken place in the systematics and the nomenclature of the family (KARSHOLT et al. 2013; HUEMER \& KARSHOLT 2020), which, however, were not reflected in the latest Romanian checklist (RÁKOSY \& GoIA 2021). In the present study we adopted these latest results, we added several species and deleted a few, and we made more then 100 additions and corrections to the distribution of the species within the country. Finally we suggest replacing the Gelechiidae in the latest Romanian checklist (RÁKosY \& GoIA 2021: 53-62, 212-221, 275, 277, 282, 288) with this list. 


\section{Acknowledgements}

We are most grateful to Peter Huemer (Innsbruck, Austria), Ole Karsholt (Copenhagen, Denmark) and Zdenko Tokár (Šal'a, Slovakia) for help in identification, confirmation of species, providing important literature, various comments, support with barcoding and many other ways. Peter Buchner (Schwarzau, Austria) was kindly helping in sequencing. Irén Kocs (formerly of the Székely National Museum, Sfântu Gheorghe, Romania), Levente Székely (Săcele, Romania), Vlad Dincă (Oulu, Finland), László Rákosy (Cluj, Romania), the late Vasile Vicol (Târgu Mureș, Romania) supported our work with loan, and Valeriu Albu (Friant, USA) also with donation of important material. Mihai Stănescu (București, Romania), Zsolt Bálint and Gergely Katona (Budapest, Hungary) and Gábriel Pastorális (Komarno, Slovakia) helped with important literature and information about materials in collections. Special thanks go to Robert J. Heckford (Plympton, U. K.) and Stella Beavan (Zeal Monachorum, U. K.) for linguistic corrections and improvement of the manuscript, and to Ole Karsholt (Copenhagen, Denmark) for his critical reading and reviewing of the manuscript.

\section{References}

Aarvik L., Bengtsson B.Å., Elven H., Ivinskis P., Jürivete U., Karsholt O., Mutanen M. \& Savenkov N. (2017) Nordic-Baltic Checklist of Lepidoptera. Norwegian Journal of Entomology. Supplement 3. $1-236$.

Abafi-Aigner L., PÁvel J. \& Uhrik N. (1896) Lepidoptera. In: Fauna Regni Hungariae III. Arthropoda. Budapest, $82 \mathrm{pp}$.

AbAfi-Aigner L. (1903) Négy hét a Székelyföldön. Adalék Háromszék vármegye lepkefaunájához. II [Four weeks in Székely-land. Contribution to the Lepidoptera fauna of Háromszék County. II]. Rovartani Lapok 10 (9): $185-192$.

Abafi-Aigner L. (1904) A Magyar lepke-fauna gyarapodása 1903-ben [The grows of the Hungarian Lepidoptera fauna in 1903]. Rovartani Lapok 11 (9): 191-193.

AdAMSKi D. \& SATTLER K. (2019) Holcophora Staudinger, 1871, a senoir synonym of Aponoea Walsingham, 1905, syn. n., (Lepidoptera, Gelechoidea, Gelechiidae): with Holcophora iderskella (Caradja, 1920), comb. n., transferred from Blastobasis Zeller, 1855 (Blastobasidae). Nota Lepidopterologica 42 (1): 17-25.

Albu V. \& Albu S. (2016) Contributions to the knowledge of the Lepidoptera species diversity in an urban park setting of Bucharest, Romania, with considerations on the species dynamics in the city over the last century. Entomologica romanica 20: 69-78.

Albu V. \& Albu S. (2018) Contributions to the knowledge of the Lepidoptera fauna of Southern Transylvania. Entomologica romanica 22: 13-56. doi: 10.24193/ entomolrom. 22.3

Albu V. \& Albu S. (2020) Contributions to the knowledge of the Lepidoptera of Vlăsia Plain (Muntenia, Romania). Entomologica romanica 24: 5-18. doi: 10.24193/ entomolrom.24.1

Anikin B. V. \& Piskunov V. I. (1996) New species of gelechiid moths from Saratov Province, Russia (Lepidoptera: Gelechiidae). Zoosystematica Rossica 4 (1) (1995): 171-175.

Anikin B. V., Sachkov S. A. \& Zolotuhin V. V. (1999) "Fauna Lepidopterologica Volgo-Uralensis" 150 years later: changes and additions. Part 4. Coleophoridae, Gelechiidae, Symmocidae and Holcopogonidae (Insecta, Lepidoptera). Atalanta 29 (1/4): 295-336.

Ardelean G. (1998) Fauna județului Satu Mare, Țara Oașului, Culmea Codrului și Câmpia Someșului [Fauna of Satu Mare County, Țara Oaşului, Culmea Codrului and Câmpia Someșului]. Vasile Goldiș University Press, Arad, 515 pp.

Beccaloni G., Scoble M., Kitching I., Simonsen T., Robinson G., Pitkin B., Hine A. \& Lyal C. (Eds) (2003) The Global Lepidoptera Names Index (LepIndex). World Wide Web electronic publication. https://www.nhm.ac.uk/our-science/data/lepindex/ lepindex/ [accessed 26 February 2019]

Bidzilya A. V., Budashinin Yu. I., Goloborod'ko K. K., Demyanenko S. A. \& Zhakov A. V. (2012) New and interesting records of Microlepidoptera (Lepidoptera) from Ukraine. Contribution 2. Eversmannia 33: 23-31. (In Russian).

BIDZILYA O. (1996) A new species of the genus Bryotropha (Lepidoptera, Gelechiidae) from the South Ukraine. Vestnik Zoologii 6: 83 (in Russian).

BIDZILYA O. (2002) The systematic position of Gelechia semicostella Staudinger, 1871 (Lepidoptera, Gelechiidae). Entomofauna, Zeitschrift für Entomologie 23: 229-236.

BIDZILYA O. (2005a) A review of the genus Metanarsia Staudinger, 1871 (Gelechiidae). Nota Lepidopterologica 27 (4): 273-297.

BIDZILYA O. (2005b) A review of the genus Athrips (Lepidoptera, Gelechiidae) in the Palaearctic region. Mitteilungen aus dem Museum für Naturkunde in Berlin. Deutsche entomologische Zeitschrift 52 (1): 3-72.

BIDZILYA O. \& BUDASHKIN YU. I. (1998) New records of Microlepidoptera from the Ukraine. Journal of the Ukrainean entomological Society 4 (3-4): 3-16 (in Russian).

BidziLya O. \& BudashKin YU. I. (2009) New records of Lepidoptera from Ukraine. Proceedings of Zoological Museum Kiev, Taras Shevchenko National University 5: 14-28 (in Russian).

Bidzilya O. A. \& Budashkin Yu. I. (2015) New Gelechiidae (Lepidoptera) from Ukraine. Zootaxa 3974 (2): 217-230.

BiDZILYA O. \& BUDASHKIN YU. I. (2017) New records of Lepidoptera from Ukraine and description of a new species of Caloptilia Hübner, 1825 (Lepidoptera, Gracillariidae) from the mountains of Crimea. Nota Lepidopterologica 40 (2): 145-161.

Bidzilya O. \& Karsholt O. (2013) Two little-known species of Gelechiidae in the European fauna. Nota Lepidopterologica 36 (1): 77-84.

BidzILYA O. \& KARSHOLT O. (2015) Revision of the genus Istrianis Meyrick, 1918 (Lepidoptera, Gelechiidae) with special regard to the Palaeartctic region. Zootaxa 4059 (3): 401-445.

Bidzilya O. \& Karsholt O. (2021) A review of the Palearctic Ptycerata Ely, 1910 (= Caulastrocecis Chrétien, 1931, syn. nov.) based on morphology (Lepidoptera, Gelechiidae). Zootaxa 5026 (2): 151181.

Bidzilya O. \& Nupponen K. (2018) New species and new records of gelechiid moths (Lepidoptera, Gelechiidae) from southern Siberia. Zootaxa 4444 (4): 381-408.

Bidzilya O., Karsholt O., Kravchenko V. \& Šumpich J. (2019a) An annotated checklist of Gelechiidae (Lepidoptera) of Israel with description of two new species. Zootaxa 4677: 1-68.

Bidzilya O., Huemer P., Nupponen K. \& Šumpich J. (2019b) A review of some new or little-known species of 
the genus Gnorimoschema (Lepidoptera, Gelechiidae) from the Palaearctic region. ZooKeys 857: 105-138. https://doi. org/10.3897/zookeys.857.34188

Bidzilya, O., J. Gastón, O. Karsholt, K. SAttler \& Vives Moreno A. 2021. A review of the genus Holcophora Staudinger, 1871, with description of three new species and new data on the taxonomy of the genus (Lepidoptera: Gelechiidae). SHILAP Revista de lepidopterologiac 49 (194): 207-246.

BobîRnaC B. \& StĂNoIU I. (1975) Contribuţii la studiul lepidopterelor din zona litoralului românesc şi Delta Dunării [Contributions to the study of Lepidoptera of the Romanian coastal zone and the Danube Delta]. Studii şi Comunicări Muzeul de Ştiinţele Naturii Bacău 8: 147-152.

BOLD Systems (see Ratnasingham S., Hebert P.D.N. (2007) (www.barcodinglife.org))

Buhl O., Falck P., Karsholt O., LARSen K. \& Vilhelmsen F. (2020) Fund af småsommerfugle fra Danmark i 2018 (Lepidoptera) [Records of Microlepidoptera from Denmark in 2018 (Lepidoptera)]. Entomologiske Meddelelser 87 (1-2) (2019): 1-18.

Burnaz S. (1993) Le catalogue de la collection de Lépidoptères du Musée du Départament de Hunedoara - Deva. Sargetia, Acta Musei Devensis, Series Scientia Naturae 14-15 (1993): 157-302.

CĂPUŞE I. (1964) Über drei Arten paläarktischer Gelechiidae: Carpatolechia dumitrescui n. g., n. sp., Aproaerema aureliana n. sp. und Mirificarma formosella (HB.) n. comb. (Lepidoptera: Gelechiidae) [About three Palaearctic Gelechiidae species: Carpatolechia dumitrescui n. g., n. sp., Aproaerema aureliana n. sp. and Mirificarma formosella (HB.) n. comb. (Lepidoptera: Gelechiidae)]. Entomologisk Tidskrift 85 (1-2): 12-19.

CĂPuşe I. \& Kovács A. (1987) Catalogue de la collection de lépidoptères "László Diószeghy" du Musée Départamental Covasna, Sfîntu Gheorghe [The catalogue of the "László Diószeghy" Lepidoptera collection of County Covasna Museum, Sfîntu Gheorghe]. Institut de Spéologie "Émile Racovitza", Bucarest. pp: 1-397.

CARAdja A. (1899) Zusammenstellung der bisher in Rumänien beobachteten Microlepidopteren [Checklist of the Microlepidoptera observed in Romania so far]. Deutsche entomologische Zeitschrift "Iris" 12: 171218.

Caradja A. (1901) Die Microlepidopteren Rumäniens [The Microlepidoptera of Romania]. Bulletin de la Société Roumaine des Sciences, Bucarest. 10 (1-2): 110-168.

CaradjA A. (1902) Die Microlepidopteren Rumäniens. Nachtrag I. Buletinul Societăţii de Şciinţe din Bucureşci 11 (5-6): 612-619.

CARAdJA A. (1905) Neuer Beitrag zur Lepidopterenfauna Rumäniens [New contribution to the Microlepidoptera of Romania]. Bulletin de la Société Roumaine des Sciences, Bucharest 14 (1-2): 227-243.

CARAdjaA. (1920) Beitrag zur Kenntnis der geographischen Verbreitung der Microlepidopteren des palaearktischen Faunengebietes nebst Beschreibung neuer Formen. III. Teil [Contribution to the knowlidge of geographical distribution of the Microlepidoptera of Palaearctic region with description of new forms. Part III]. Deutsche entomologische Zeitschrift "Iris" 34: 75-179.

Caradja A. (1929) Badereise eines Naturfreundes nach Tekirghiol (Carmen Silva). Ein Beitrag zur Lepidopterenfauna der Dobrogea. Deutsche entomologische Zeitschrift "Iris" Dresden 41: 41-65.

CARAdja A. (1931) Beiträge zur Lepidopterenfauna Grossrumänien für Jahr 1930. Academia Română,
Memoriile Secțiunii Ştiințifice, Bucureşti 3 (7): 293344.

CARADJA A. (1932) Beiträge zur Lepidopterenfauna Grossrumäniens für das Jahr 1931. Acadèmie Roumaine, Bulletin la Section Scientifique, Bucarest 15 (1-2): 35-46.

Cean M. \& Dobrin I. 2010. Tuta absoluta (Povolný, 1994) un nou dăunător minier pentru România [Tuta absoluta (Povolný, 1994) a new mining pest for Romania]. Buletin de informare entomologică 20 (2009): 129-133.

Ciobanu M., Drosu S. \& IAmandei M. (2010) Molia cartofului Phthorimaea operculella Zeller (Lepidoptera: Gelechiidae) potential dăunător al culturii de cartof din România [Potat tuber moth Phthorimaea operculella Zeller (Lepidoptera: Gelechiidae), a potential potato pest in Romania]. Sănătatea Plantelor 143 (4): 25.

Corley M. F. V., Rosete J. \& Ferreira S. (2020) Mondegiuna, a new genus for Apapetris mediterranella Nel \& Varenne, 2012, with description of a new species from Portugal (Lepidoptera, Gelechiidae). Nota Lepidopterologica 43: 151-166.

CoRLEy M.F. V.(2014)Five new species of Microlepidoptera from Portugal. Entomologist's Reccord and Journal of Variation 126: 229-243.

Czekelius D. (1897) Beiträge zur Lepidopteren- und Odonaten-Fauna Siebenbürgens [Contributions to the Lepidoptera and Odonata fauna of Transylvania V]. Verhandlungen und Mitteilungen des siebenbürgischen Vereins für Naturwissenschaften zu Hermannstadt 46 (1896): 82-88.

Czekelius D. (1898) Kritisches Verzeichnis der Schmettterlinge Siebenbürgens [A critical checklist of the Lepidoptera of Transylvania]. Verhandlungen und Mitteilungen des siebenbürgischen Vereins für Naturwissenschaften zu Hermannstadt 47 (1897): 1-78.

Czekelius D (1900) Beiträge zur Schmetterlingsfauna Siebenbürgens I-II [Contributions to the Lepidoptera fauna of Transylvania I-II]. Verhandlungen und Mitteilungen des siebenbürgischen Vereins für Naturwissenschaften zu Hermannstadt 48 (1898): 151153.

Czekelius D (1901) Beiträge zur Schmetterlingsfauna Siebenbürgens III [Contributions to the Lepidoptera fauna of Transylvania III]. Verhandlungen und Mitteilungen des siebenbürgischen Vereins für Naturwissenschaften zu Hermannstadt 50 (1900): 8088.

Czekelius D (1905) Beiträge zur Schmetterlingsfauna Siebenbürgens IV [Contributions to the Lepidoptera fauna of Transylvania IV]. Verhandlungen und Mitteilungen des siebenbürgischen Vereins für Naturwissenschaften zu Hermannstadt 53 (1903): 8183.

Czekelius D. (1909) Beiträge zur Schmetterlingsfauna Siebenbürgens V [Contributions to the Lepidoptera fauna of Transylvania V]. Verhandlungen und Mitteilungen des siebenbürgischen Vereins für Naturwissenschaften zu Hermannstadt 58 (1908): 153-164.

Czekelius D. (1918) Beiträge zur Schmetterlingsfauna Siebenbürgens VI [Contributions to the Lepidoptera fauna of Transylvania VI]. Verhandlungen und Mitteilungen des siebenbürgischen Vereins für Naturwissenschaften zu Hermannstadt 67 (1-6) (1917): $1-56$.

Czekelius D. (1924) Beiträge zur Schmetterlingsfauna Siebenbürgens VIII [Contributions to the Lepidoptera fauna of Transylvania VIII]. Verhandlungen und Mitteilungen des siebenbürgischen Vereins für Naturwissenschaften zu Hermannstadt 72-74 (19221924): 248-257.

Czekelius D. (1934) Beiträge zur Schmetterlingsfauna 
Siebenbürgens IX [Contributions to the Lepidoptera fauna of Transylvania IX]. Verhandlungen und Mitteilungen des siebenbürgischen Vereins für Naturwissenschaften zu Hermannstadt 83-84 (19331934): 59-69.

Diószeghy L. (1930a) Die Lepidopterenfauna des Retyezatgebirges [The Lepidoptera fauna of the Retezat Mountains]. Verhandlungen und Mitteilungen des siebenbürgischen Vereins für Naturwissenschaften zu Hermannstadt 79-80 (1929-1930): 189-289.

DiószEGHY L. (1930b) Beiträge zur Lepidopterenfauna des Retyezatgebirges [Contributions to the Lepidoptera fauna of the Retezat Mountains]. Publicatiile Muzeului Județean Hunedoara, Deva, 5 (2): 5-27.

Diószeghy L. (1935) Die Lepidopterenfauna des Retyezatgebirges. Nachtrag I [The Lepidoptera fauna of the Retezat Mountains. Addendum I]. Verhandlungen und Mitteilungen des siebenbürgischen Vereins für Naturwissenschaften zu Hermannstadt 83-84 (19331934): 107-126.

Donescu D. (2009) Atenţie, molia cartofului (Phthorimaea operculella) „,bate la uşă”! [Beware of potato tuber moth (Phthorimaea operculella)]. Cartoful în România $18(1 / 2): 71$.

DrĂGHIA I. (1970) Nouvelles contributions à la connaissance des insectes mineurs de Bucarest et de ses environs [New contributions to the knowledge of mining insects of Bucharest and its surroundings]. Travaux du Muséum d'Histoire Naturelle „, Grigore Antipa" 10: 235-240.

DRĂGHIA I. (1976) Insectes mineurs. In: L'Entomofaune du nord de la Dobrogea, la zone Măcin-Tulcea-Niculițel [Mining insects. In: The entomofauna of northern Dobrudja, the Măcin-Tulcea-Niculiţel area]. Travaux du Muséum d'Histoire Naturelle „, Grigore Antipa “ 17: 179-183.

ElSNer G. \& Karsholt O. (2003) Bryotropha patockai sp. nov. - a new species of Gelechiidae from eastern Central Europe (Lepidoptera). Entomologische Zeitschrift 113 (3): 72-74.

Elsner G., Huemer P. \& ToKÁr Z. (1999) Die Palpenmotten (Lepidoptera, Gelechiidae) Mitteleuropas. Bestimmung - Verbreitung - Flugstandort - Lebensweise der Raupen [The Gelechiid Moths (Lepidoptera, Gelechiidae) of Central Europe. Identification - Distribution - Habitat - Bionomics of larvae]. Bratislava. 1-208.

ENGLERT W. D. (1974) Revision der Gattung Metzneria Zeller (Lepid., Gelechiidae) mit Beiträgen zur Biologie der Arten [Review of the genus Metzneria Zeller (Lepid., Gelechiidae) with contributions to the biology of the species]. Zeitschrift für Angewandte Entomologie 75: $381-421$.

EPPO (2021) European and Mediterranean Plant Protection Organization (EPPO) (accessed 8 October 2021).

Gozmány L. (1953) New Data to the Microlepidoptera Fauna of the Retyezát Range. Annales historiconaturales Musei Nationalis Hungarici (s. nova) 4: 181-185.

GozmÁny L. (1957) Notes on the generic group Stomopteryx Hein., and the descriptions of some new Microlepidoptera. Acta Zoologica Academiae Scientiarum Hungaricae 3 (1-2): 107-135.

Gozmány L. (1958) Molylepkék IV. (Microlepidoptera IV). Fauna Hungariae 40. Akadémiai Kiadó. Budapest, $1-295$.

Gregersen K. \& Karsholt O. (2017) Taxonomic confusion around the Peach Twig Borer, Anarsia lineatella Zeller, 1839, with description of a new species (Lepidoptera, Gelechiidae). Nota Lepidopterologica 40 (1): 65-85.

Hedemann W. (1897) Microlepidopterologische Sammel-Ergebnisse aus Herkulesbad (Mehadia)
[Microlepidopterological collection results from Herculane Bath (Mehadia)]. Verhandlungen der Zoologisch-Botanischen Gesellschaft in Wien 47: 2730.

Hormuzaki C. (1907) Die Schmetterlinge (Lepidoptera) der Bukowina. (III). Fam. Pyralidae bis Micropterigidae [The moths (Lepidoptera) of the Bukowina. (III). Fam. Pyralidae to Micropterigidae]. Verhandlungen der Zoologisch-Botanischen Gesellschaft in Wien 57: 34104.

HuEmer P. (1988) A taxonomic revision of Caryocolum (Lepidoptera, Gelechiidae). Bulletin of the British Museum (Natural History). Entomology series 57 (3): 439-571.

Huemer P. (1993) Europäische Arten der Gattung Thiotricha (= Reuttia) (Lepidoptera: Gelechiidae) [The European species of the genus Thiotricha (= Reuttia) (Lepidoptera: Gelechiidae)]. Nota Lepidopterologica 16 (1): 44-56.

HuEmer P. (2019) DNA-Barcoding und Faunistik: Erstnachweise von Schmetterlingen (Lepidoptera) für Italien. Gredleriana 19: 87-94.

Huemer P. (2020) Integrative revision of the Caryocolum schleichi species group - a striking example of a temporally changing species concept (Lepidoptera, Gelechiidae). Alpine Entomology 4: 39-63. DOI 10.3897/alpento.4.50703

Huemer P. \& Karsholt O. (1998) A review of the Old World Scrobipalpula (Gelechiidae), with special reference to central and northern Europe. Nota Lepidopterologica 21 (1): 37-65.

Huemer P. \& Karsholt O. (1999) Gelechiidae I (Gelechiinae: Teleiodini, Gelechiini). In: Huemer P., Karsholt O. \& L. LyNEBORG (Eds): Microlepidoptera of Europe 3. Apollo Books. Stenstrup, pp. 356.

Huemer P. \& Karsholt O. (2001) Additions to the fauna of Gelechiidae (Gelechiinae: Teleiodini and Gelechiini) of Europe. Nota Lepidopterologica 24 (3): 41-55.

Huemer P. \& Karsholt O. (2002) A review of the genus Acompsia Hübner, 1825, with description of new species (Gelechiidae). Nota Lepidopterologica 25 (23): 109-151.

Huemer P. \& Karsholt O. (2010) Gelechiidae II (Gelechiinae: Gnorimoschemini). In: HUEMER P., Karsholt O. \& M. Nuss (Eds) Microlepidoptera of Europe 6. Apollo Books. Stenstrup, pp. 586.

Huemer P. \& Karsholt O. (2011) Eulamprotes libertinella auctt. - ein Komplex kryptischer alpiner „Kleinschmetterlinge” (Lepidoptera, Gelechiidae)? [Eulamprotes libertinella auctt. - a complex of cryptic alpine „Micromoths" (Lepidoptera, Gelechiidae)?] Entomologische Nachrichten und Berichte 55 (4): 217229.

Huemer P. \& Karsholt O. (2018) Revision of the genus Megacraspedus Zeller, 1839, a challenging taxonomic tightrope of species delimitation (Lepidoptera, Gelechiidae). ZooKeys 800: 1-278. https://doi. org/10.3897/zookeys.800.26292

Huemer P., Karsholt O. (2020) Commented checklist of European Gelechiidae (Lepidoptera). ZooKeys 921: 65-140. https://doi.org/10.3897/zookeys.921.49197

Huemer P. \& Rabitsch W. (2002) Schmetterlinge (Lepidoptera). [Moths (Lepidoptera)]. 354-362. In: EssL F. \& RABITSCH W. (Eds) Neobiota in Österreich. (Neobiota in Austria]. Wien.

Huemer P. \& SAttler K. (1995) A taxonomic revision of Palaearctic Chionodes (Lepidoptera: Gelechiidae). Beiträge zur Entomologie 45 (1): 3-108.

Huemer P. \& TOKÁR Z. (2000) Psamathocrita dalmatinella sp.n., eine verkannte Schmetterlingsart aus dem Mediterraneum (Lepidoptera, Gelechiidae) 
[Psamathocrita dalmatinella sp.n., a misidentified moths from the Mediterranean (Lepidoptera, Gelechiidae)]. Zeitschrift der Arbeitsgemainschaft österreicher Entomologen 52: 1-10.

HuEMER P. \& Wieser C. (2020) Bemerkenswerte Neufunde von Schmetterlingen (Lepidoptera) für Italien (Cottische Alpen) [Remarcable new records of Lepidoptera for Italy (Cottian Alps)]. Carinthia II, 210/130: 457-470.

Huemer P., Elsner G. \& Karsholt O. (2013) Review of the Eulamprotes wilkella species-group based on morphology and DNA barcodes, with description of new taxa Lepidoptera, Gelechiidae). Zootaxa 3746 (1): 69-100.

Huemer P., Karsholt O. \& Mutanen M. (2014) DNA barcoding as a screening tool for cryptic diversity: an example from Caryocolum, with description of a new species (Lepidoptera, Gelechiidae). ZooKeys 404: 91111.

Huemer P., Hebert P. D. N., Mutanen M., Wieser C., Wiesmair B., Hausmann A. et al. (2018) Large geographical distance versus small DNA barcode divergence: Insights from a comparison of European to South Siberian Lepidoptera. PLoS ONE 13(11): e0206668. https://doi.org/10.1371/journal. pone. 0206668

Huemer P., Karsholt O., Aarvik L., Berggren K., Bidzilya O., Junnilainen J., Landry J.-F., Mutanen M., Nupponen K., Segerer A., Šumpich J., Wieser C., Wiesmair B., Hebert P. D. N. (2020) DNA barcode library for European Gelechiidae (Lepidoptera) suggests greatly underestimated species diversity. ZooKeys 921: 141-157. https://doi.org/10.3897/ zookeys.921.49199

JunNILAINEN J. \& NuPPONEN K. (2010) The gelechiid fauna of the Southern Ural Mountains, part I: descriptions of seventeen new species (Lepidoptera: Gelechiidae). Zootaxa 2366: 1-34.

JunNilainen J., Karsholt O., Nupponen K., Kaitila J. \& NuPPONEN T. (2010) The gelechiid fauna of the Southern Ural Mountains, part II: list of recorded species with taxonomic notes (Lepidoptera: Gelechiidae). Zootaxa 2367: 1-68.

Karsholt O. (1995) Kommentiertes Verzeichnis der Symmocidae, Blastobasidae und Gelechiidae Ostdeutschlands (Lepidoptera) [Commented checklist of the Symmocidae, Blastobasidae and Gelechiidae of East Germany (Lepidoptera)]. Beiträge zur Entomologie 45 (1): $137-154$.

Karsholt O. (2004-2020) Gelechiidae. In: Karsholt O. \& VAN NIEUKERKen E. J. (Eds) Lepidoptera. Fauna Europaea. Last update of Gelechiidae Version 2.4 January 2011. https://fauna-eu.org/.

Karsholt O. \& RiedL T. (1996) Gelechiidae (excluding Gnorimoschemini). In: KaRSHOLT O. \& RazowsKI J. (Eds) The Lepidoptera of Europe. A distributional checklist. Apollo Books, Stenstrup, 380 pp.

Karsholt O. \& RutTen T. (2005) The genus Bryotropha Heinemann in the Western Palaearctic (Lepidoptera, Gelechiidae). Tijdschrift voor Entomologie 148: 77207.

KarSholt O. \& ŠumPich J. (2015) A review of the genus Nothris Hübner, 1825, with description of new species (Lepidoptera, Gelechiidae). Zootaxa 4059 (3): 471498.

Karsholt O., Mutanen M., Lee S. \& Kaila L. (2013) A molecular analysis of Gelechiidae (Lepidoptera, Gelechioidea) with an interpretative grouping of its taxa. Systematic Entomology 38: 334-348.

KASYF.(1963)Zwei fürÖsterreichneueKleinschmetterlinge aus der Umgebung von Wien [Two Microlepidoptera species from the surroundings of Vienna new for Austria) Zeitschrift der Arbeitsgemainschaft österreicher Entomologen 15 (1-2): 53.

KASY F. (1965) Lepidopterologisch-faunistisch bemerkenswerte Neufunde aus Niederösterreich II [Interesting faunistic new records of Lepidoptera from Lower Austria II]. Zeitschrift der Arbeitsgemainschaft österreicher Entomologen 17 (1-2): 5-8.

Kovács Z. \& Kovícs S. (1994) Gelechiidae (Lepidoptera) mentioned in the Romanian fauna for the first time. Travaux du Muséum d'Histoire Naturelle „Grigore Antipa" 34: 35-50.

Kovícs Z. \& Kovács S. (2000) The commented checklist of Gelechiidae (Lepidoptera) of Romania. Entomologica romanica 4 (1999): 11-44.

Kovács Z. \& Kovícs S. (2001) The catalogue of Gelechiidae (Lepidoptera) of the „László Diószeghy” collection of the Székely National Museum. Acta - 2000: 89-101.

Kovács Z. \& Kovács S. (2002a) A new species of Filatima Busck, 1939 (Lepidoptera, Gelechiidae) from Transylvania, Romania. Acta Zoologica Academiae Scientiarum Hungaricae 47 (4) (2001): 363-370.

Kovács Z. \& Kovícs S. (2002b) New records of Gelechiidae (Lepidoptera) to the fauna of Romania. Entomologica romanica 6 (2001): 41-43.

Kovács S., Rákosy L., Kovács Z., Cremene C. \& Goia M. (2002) Lepidoptere din Rezervaţia naturală „,Dealul cu fluturi" de la Viişoara (jud. Cluj) [The Lepidoptera of the "Lepidoptera Hill" from Viişoara (Cluj County)]. Buletin de informare Societatea Lepidopterologică Română 12 (1-4) (2001): 47-85.

KöNIG F. (1998) Contribuţii la cunoaşterea faunei de lepidoptere a zonei de agrement „Pădurea Verde“, a parcurilor centrale şi grădinilor periferice din municipiul Timişoara între anii 1921-1998 [Contributions to the knowledge of Lepidoptera fauna of the leisure area „Pădurea Verde“, of central parks and the gardens from the periphery of Timişoara town between 1921-1998]. Analele Banatului, Timişoara. 4: 165-184.

Landry J. F., Nazari V., Bidzilya O., Huemer P. \& KARSHOLt O. (2017) Review of the genus Agonochaetia Povolný (Lepidoptera, Gelechiidae), and description of a new genus and species from the Canary Islands. Zootaxa 4300 (4): 451-485.

LEAotǍ E. (2009) Prima semnalare în România a organismului dăunător Tuta absoluta (minierul frunzelor de tomate) [First record in Romania of the pest Tuta absoluta (Tomato Liefminer)]. Sănătatea plantelor 135.

LeE S. \& Brown R. L. (2008) Revision of Holarctic Teleiodini (Lepidoptera: Gelechiidae). Zootaxa 1818: $1-55$.

Li H. \& SatTler K. (2012) A taxonomic revision of the genus Mesophleps Hübner, 1825. (Lepidoptera: Gelechiidae). Zootaxa 3373: 1-82.

LEPIFORUM 2019. http://www.lepiforum.de/lepiwiki.pl (accessed 27.03.2019).

Lopez-Vaamonde C., Agassiz D., Augustin S., De Prins J., De Prins W., Gomboc S., Ivinskis P., Karsholt O., Koutroumpas A., Koutroumpa F., Laštưvka Z., Marabuto E., Olivella E., Przybylowicz L., Roques A., Ryrholm N., Šefrová H., Šima P., Sims I., Sinev S, Skulev B., Tomov R., Zilli A. \& Lees D. (2010) Lepidoptera. Chapter 11. In: Roques A. et al. (Eds) Alien terrestrial arthropods of Europe. BioRisk 4(2): 603-668. doi: 10.3897/biorisk.4.50

MANN J. (1861) Zur Lepidopteren-Fauna von Amasia. Wiener entomologische Monatschrift 5: $155-$ 162, 183-193, pls 2-3.

ManN J. (1866) Aufzählung der im Jahre 1865 in der Dobrudscha gesammelten Schmetterlingen [List of the Lepidoptera collected in Dobrudja in the year 1865]. Verhandlungen der kaiserlich-königlichen zoologisch- 
botanischen Gesellschaft in Wien 16: 321-360.

Minuț S. (1998) Lepidoptere din zona localităţii Bădeni (nord-estul Câmpiei Transilvaniei) [Lepidoptera of the area of Bădeni (north-eastern Transylvanian Plane)]. Buletin de informare Societatea Lepidopterologică Română 8 (1-2): (1997) 67-77.

Neacşu P. \& DrĂGHIA I. (1973) Données écologiques sur certaines Lepidoptera et Diptera dans la forêt de Petreşti, district Vrancea [Data to the ecology of some Lepidoptera and Diptera from Petreşti forest, Vrancea County]. Travaux du Muséum d'Histoire Naturelle „, Grigore Antipa“ 13: 195-202.

Nel J. \& VARENne T. (2012) Pseudopostega cyrneochalcopepla n. sp., Monochroa cyrneogonella $\mathrm{n}$. sp., Syncopacma cinctelloides n. sp., espèces nouvelles découvertes en Corse (Lep. Opostegidae, Gelechiidae). Oreina 17: 11-13.

NemEŞ I. (1968) Contribution à la connaissance de la famille Symmocidae dans la faune de la Roumanie (Lepidoptera) [Contribution to the knowledge of the family Symmocidae in the fauna of Romania (Lepidoptera)]. Travaux du Muséum d'Histoire Naturelle ,, Grigore Antipa “ 8: 865-874.

Nemeş I. (1972a) Asupra faunei lepidopterologice din zona viitorului lac de acumulare de la „Porţile de Fier“. Partea I [About the Lepidoptera fauna of the future lake „Iron Gate“. Part I]. Studii şi Comunicări. Consiliul Județean pentru Ocrotirea Naturii Suceava 2: 201-215.

Nemeş I. (1972b) Fauna de lepidoptere a judeţului Botoşani. Partea I-a [The Lepidoptera fauna of Botoşani County. Part I]. Studii şi Comunicări. Muzeul de Ştiinţele Naturii Dorohoi 179-186.

Nemeş I. (1974) Contribuţii la cunoaşterea lepidopterelor din judeţul Neamţ. (Partea I: Agapia) [Contributions to the knowledge of Lepidoptera of Neamţ County. (Part I: Agapia)]. Muzeul de Ştiinţele Naturale Piatra Neamţ. Studii şi Cercetări de Geologie-Geografie-Biologie seria Botanică-Zoologie 203-216.

Nemeş I. \& DĂNILĂ I. (1970) Catalogul colecţiei de lepidoptere "Alexei Alexinschi” de la Muzeul Judeţean Suceava. Partea I-a, Fam. Micropterigidae - Fam. Zygaenidae [Catalogue of the "Alexei Alexinschi" Lepidoptera collection of the Departamental Muzeum Suceava. Part I, Fam. Micropterigidae - Fam. Zygaenidae]. Studii şi Comunicări, Stiinţe Naturale, Suceava: 131-265.

Nemeş I. \& Lungoci A. (1973) Lepidopterele din judeţul Suceava [The Lepidoptera of Suceava County]. Studii şi Comunicări, Ocrotirea Naturii Suceava: 233-247.

Olaru V. \& Nemeş I. (1968) Contribuţii la cunoaşterea lepidopterelor din pădurea Gârboavele (Nota II) [Contributions to the knowledge of Lepidoptera of Gârboavele forest. (Annotation II)]. Institutul Pedagogic Galaţi, Lucrări Ştiinţifice 2: 167-177.

Olaru V. \& Nemeş I. (1969) Contribuţii la cunoaşterea lepidopterelor din pădurea Gârboavele (Nota III) [Contributions to the knowledge of Lepidoptera of Gârboavele forest. (Annotation III)]. Institutul Pedagogic Galaţi, Lucrări Ştiinţifice 3: 126-133.

Park K. T. \& Ponomarenko M. G. (2006) A new species of Parastenolechia Kanazawa (Lepidoptera: Gelechiidae) from Korea, with a checklist of the genus. Zootaxa 1338: 49-55.

Pastorális G. (2014) A Coleophora mareki Tabell \& Baldizzone, 2014, Scrobipalpula diffluella (Frey, 1870) és Epinotia nigristriana Budashkin \& Zlatkov, 2011 új fajok Magyarországon [Coleophora mareki Tabell \& Baldizzone, 2014, Scrobipalpula diffluella (Frey, 1870) and Epinotia nigristriana Budashkin \& Zlatkov, 2011 new species in Hungary] (Lepidoptera: Coleophoridae, Gelechiidae, Tortricidae). Tinea Hungarica 2014 (1):
$1-3$.

Pastorális G. \& Szeőke K. (2018) A Vértes hegység lepkefaunája (Lepidoptera) [The Lepidoptera fauna of the Vértes Mountains (Lepidoptera)]. e-Acta Naturalia Pannonica 17: 1-73.

Pastorális G., Kosorín F., ToKÁr Z., Richter I., ŠUMPICH J., LišKa J., LAŠTƯVKa A., LAŠTƯVKa Z. \& ENDEL B. (2018) Sixteen species of moths (Lepidoptera) new for fauna of Slovakia. Entomofauna carpathica 30 (2): $1-24$.

PÁvel J. (1897) A Mezőség lepke-faunája [The Lepidoptera fauna of the Transylvanian Plane]. Rovartani Lapok 4 (5): 104-107.

PÁvel J. (1898) Kirándulás Besztercze-Naszód megyébe [Trip in Bistrița-Năsăud County]. Rovartani Lapok 5 (1): 17-18.

Peiu M. \& Nemeş I. (1970) Fauna de lepidoptere a masivelor Rarău-Giumalău. (Partea I-a) [The Lepidoptera fauna of the Rarău-Giumalău Massifs. (Part I)]. Studii şi Comunicări, Ocrotirea Naturii, Suceava 47-75.

PerJu T. \& Peiu M. (1968) Cercetări de bioecologie asupra unor specii de lepidoptere seminifage [Bioecological research on seed feeder Lepidoptera]. Lucrările celei de a III-a Conferinţă Entomologică Iaşi, 20-22 mai 1983: 423-430.

Pitkin M. L. (1984) Gelechiid moths of the genus Mirificarma. Bulletin of the British Museum (Natural History). Entomology series 48 (1): 1-70.

PitKIn M. L. (1988) The Holarctic genus Teleiopsis: hostplants, biogeography and cladistics (Lepidoptera: Gelechiidae). Entomologica Scandinavica 19: 143-191.

Popescu-GorJ A. (1964) Catalogue de la colection de lépidoptères „Prof. A. Ostrogovich” du Museum d'Histoire Naturelle "Grigore Antipa" Bucarest [Catalogue of the „Prof. A. Ostrogovich” Lepidoptera collection of ,Grigore Antipa” Natural History Museum in Bucharest]. Ed. Mus. „Grigore Antipa” Bucarest. pp: $1-293$.

Popescu-GorJ A. (1970) Nouvelles données pour la connaissance des Lépidoptères de Sulina et du „grind““ Caraorman (Delta du Danube) [New data to the knowledge of Lepidoptera of Sulina and the „grind“ Caraorman (Danube Delta)]. Travaux du Muséum d'Histoire Naturelle ,, Grigore Antipa “ 10: 91-102.

POPESCU-GorJ A. (1976) Ord. Lepidoptera. In: L'entomofaune du nord de la Dobrogea, la zone Măcin-Tulcea-Niculiţel [Ord. Lepidoptera. In: The entomofauna of northern Dobrudja, the MăcinTulcea-Niculiţel area]. Travaux du Muséum d'Histoire Naturelle ,, Grigore Antipa “ 17: 159-172.

PopesCU-GorJA. (1984)La liste systématique des espèces de Microlépidoptères signalées dans la faune de Roumanie, mise á jour de leur classification et nomenclature [The systematic list of the Microlepidoptera species recorded in the fauna of Romania, the update of their classification and nomenclature]. Travaux du Muséum d'Histoire Naturelle "Grigore Antipa" 26: 111-162.

Popescu-GorJ A. (1985a) Nouvelles données pour la connaissance des Microlépidoptères de Roumanie [New data for the knowledge of Microlepidoptera of Romania) Travaux du Muséum d'Histoire Naturelle "Grigore Antipa” 27: 101-119.

PoPescu-GorJ A. (1985b) Rezultatele noilor cercetări privind fauna de Lepidoptere a Deltei Dunării (Grindul Letea) [The results of the new research on the Lepidoptera fauna of the Danube Delta (Grindul Letea)]. Studii şi Comunicări de Entomologie. Delta Dunării. Tulcea 2: 65-85.

PoPescu-GorJ A. (1986) Espèces nouvelles ou peu connues dans la faune de Microlépidoptères de Roumanie [New and little known Microlepidoptera species in the fauna 
of Romania]. Travaux du Muséum d'Histoire Naturelle „, Grigore Antipa“ 28: 79-83.

POPESCU-GoRJ A. 1995. Lepidopterans from the surroundings of the Town Sinaia and from Bucegi Mountains (Romania). Travaux du Muséum d'Histoire Naturelle ,, Grigore Antipa“ 35: 161-220.

Popescu-GorJ A. \& DRĂGHIA I. (1964) Noi cercetări privind fauna de lepidoptere din nordul şi sudul Dobrogei [New research concerning the Lepidoptera fauna of northern and southern Dobrudja]. Studii şi Cercetări de Biologie, Academia RPR, seria Zoologie 16 (1): 27-38.

Popescu-GorJ A. \& DrĂGHIA I. (1967) Ord. Lepidoptera. In: L'Entomofaune des forêts du sud de Dobroudja [Ord. Lepidoptera. In: The entomofauna of the forests of southern Dobrudja]. Travaux du Muséum d'Histoire Naturelle ,, Grigore Antipa “ 7: 181-212.

Popescu-GorJ A. \& DrĂGHIA I. 1968. Ord. Lepidoptera. In: Popescu-Gorj A. \& X. Scobiola-Palade (Eds) L'Entomofaune de l'Ile de Letea (Delta du Danube) [Ord. Lepidoptera. In: The entomofauna of the Letea Island (Danube Delta)]. Travaux du Muséum d'Histoire Naturelle ,Grigore Antipa” 9: 227-278.

Popescu-GorJ A. \& Nemeş I. (1965) Les Microlépidoptères de la région de Suceava (Roumanie) [The Microlepidoptera of Suceava region]. Travaux $d u$ Muséum d'Histoire Naturelle „Grigore Antipa“ 5: $147-184$.

Popescu-Gorj A., Olaru V. \& Drăghia I. (1972) Ord. Lepidoptera. In: Popescu-GorJ A. \& X. ScobiolaPalade (Eds) L'Entomofaune du „Grind“ de Caraorman, Delta du Danube [Ord. Lepidoptera. In: The entomofauna of the "Grind" of Caraorman, the Danube Delta]. Travaux du Muséum d'Histoire Naturelle ,, Grigore Antipa “ 12: 181-206.

Povolný D. (1996) Gnorimoschemini. In: Karsholt O. \& Razowski J. (Eds) The Lepidoptera of Europe. A distributional checklist. Apollo Books, Stenstrup, 380 pp.

PovolnÝ D. (2002) Iconographia tribus Gnorimoschemini (Lepidoptera, Gelechiidae) Regionis Palaearcticae. Slamka. 110 pp., 16 colour pls, 87 pls, Bratislava.

RÁKosy L. (1998) Die endemischen Lepidopteren Rumäniens (Insecta: Lepidoptera) [The endemic Lepidoptera of Romania (Insecta: Lepidoptera)]. Staphia 55: 257-280.

RÁKosy L. (2002) Diversität der Schmetterlinge (Lepidoptera) im Cheile Turzii Naturschutzgebiet (Siebenbürgen, Rumänien) [Diversity of butterflies and moths (Lepidoptera) in the Turda Gorge Nature Reserve (Transylvania, Romania)]. Entomologica Romanica 6 (2001): 55-92.

RÁKosy L. (2013) Endemic Lepidoptera of Carpathians and their Balkanic connections. In: XVIII European Congress of Lepidopterology - 29 July - 4 August 2013, Blagoevgrad, Bulgaria. Programme and Abstracts, Pensoft, Sofia: 69-70.

Rákosy L. \& Goia M. (2007) Addenda und Corrigenda zu dem Verzeichniss der Schmetterlinge Rumäniens [Addenda and Corrigenda to the catalogue of the Lepidoptera of Romania]. Entomologica romanica 11 (2006): 69-79.

RÁKosy L. \& Goia M. (2021) Lepidopterele din România: lista sistematică și distribuție / The Lepidoptera of Romania: a Distributional Checklist. Presa Universitară Clujeană, pp. 369.

RÁKosy L. \& WIESER C. (2010) Diversität bei Schmetterlingen (Lepidoptera) im Gebiet von Rimetea (Eisenburg) (Transsilvanien, Rumänien) [Diversity of butterflies and moths (Lepidoptera) in the Rimetea (Eisenburg) area (Transylvania, Romania)]. Buletin de informare Entomologică 21: 36-83.
Rákosy L., Goia M. \& Kovács Z. (2003) Catalogul Lepidoterelor României / Verzeichniss der Schmetterlinge Rumäniens [The catalogue of the Lepidoptera of Romania]. Societatea Lepidopterologică Română. Cluj-Napoca. 1-446.

RÁKosy L., VicOL V., SzÉKelY L. \& GoIA M. (1998) Lepidoptera, pp: 18-32. In: Rezultatele taberei entomologice din Cheile Tișiței, Munții Vrancei, 26.066.07.1997 [Lepidoptera, pp: 18-32. In: The results of the entomological camp in Tișiței Gorge, Vrancei Mountains, 26.06-6.07.1997]. Buletin de informare Societatea Entomologică Română 8 (1-2) (1997).

Ratnasingham S., Hebert P.D.N. (2007) BOLD: The Barcode of Life Data System (http://www.barcodinglife. org). Molecular Ecology Notes 7: 355-364. https://doi.org/10.1111/j.1471-8286.2007.01678.x

Rebel H. (1908) Lepidopterologische Exkursion in die transsylvanischen Alpen [Trip of lepidopterists in the Transylvanian Alps]. Verhandlungen der ZoologischBotanischen Gesellschaft in Wien 58: 74-80.

ReBel H. (1911) Die Lepidopterenfauna von Herkulesbad und Orsova. Eine zoogeographische Studie [The Lepidoptera fauna of Herkulane Bath and Orsova. A zoogeographical study]. Annalen des $k$. $k$. Naturhistorischen Hofmuseums, Wien 25: 253-430.

RIST O. (2014) Erstnachweise von Elachista pomerana (Lepidoptera: Elachistidae) und Helcystogramma albinervis (Lepidoptera: Gelechiidae) aus Österreich [First record of Elachista pomerana (Lepidoptera: Elachistidae) and Helcystogramma albinervis (Lepidoptera: Gelechiidae) in Austria]. Zeitschrift der Arbeitsgemeinschaft Österreichischer Entomologen 66: $1-5$.

RothschiLd N. CH. (1912a) Beitrag zur Lepidopterenfauna der Mezőség [Contribution to Lepidoptera fauna of the Transylvanian Plane]. Verhandlungen und Mitteilungen des siebenbürgischen Vereins für Naturwissenschaften zu Hermannstadt 62 (1): 1-32.

Rothschild N. CH. (1912b) Adatok Magyarország lepkefaunájához [Data to the Lepidoptera fauna of Hungary]. Rovartani Lapok 19 (2-3): 21-29.

Rothschild N. CH. (1912c) Adatok Magyarország lepkefaunájához IV. Lepkék Szvinicza környékéről (Beiträge zur Lepidopterenfauna Ungarns IV. Lepidopteren von Szvinicza und Umgebung) [Data to the Lepidoptera fauna of Hungary IV. The Lepidoptera of the environs of Szvinicza]. Rovartani Lapok 19 (10 12): 167-180.

RutTen T. \& KARShOLT O. (2004) Review of the Nearctic species of Bryotropha (Lepidoptera, Gelechiidae). Zootaxa 740: 1-42.

SATTLER K. (1976) A taxonomic revision of the genus Ornativalva Gozmány, 1955 (Lepidoptera: Gelechiidae). Bulletin of the British Museum (Natural History). Entomology series 34 (2): 87-152, 27 pls.

SATTLER K. (1986) Die an Compositen gebundenen Scrobipalpa-Arten der östlichen Österreichs (Lepidoptera, Gelechiidae) [The Scrobipalpa species confined to Compositae in eastern Austria (Lepidoptera, Gelechiidae)]. Annalen des Naturhistorischen Museums in Wien 88/89B: 435-456.

ScHmid J. (2011) Teleiopsis laetitiae sp. n. and Teleiopsis lindae sp. n., two hitherto overlooked mountain European species (Gelechiidae: Teleiodini). Nota Lepidopterologica 33 (2): 271-283.

Segerer A. \& Huemer P. (2020) Aproaerema cinctelloides (Nel \& Varenne, 2012) is not a Mediterranean island endemic (Lepidoptera, Gelechiidae, Anacampsinae). Spixiana 43: 147-148.

STĂNESCU M. \& RuşTI D. (1997) New data concerning the Lepidoptera (Insecta) of Maramureș (Romania). 
Travaux du Muséum National d'Histoire Naturelle „, Grigore Antipa “ 37: 89-111.

STĂNoIU I. M. (1971) Cercetări noi asupra faunei de microlepidoptere (Insecta) din Oltenia [New research on the Microlepidoptera (Insecta) fauna of Oltenia]. Subcomisia Monumentelor Naturii Oltenia, Craiova, Studii și Cercetări 161-165.

STĂNOIU I. M. \& ChimişLIU C. (1993) Noi cercetări asupra microlepidopterelor din Oltenia [New research on the Microlepidoptera of Oltenia]. Oltenia, Studii și Comunicări, Muzeul Olteniei Craiova 1990-1993: 41-45.

StăNoiU I. M., BobîrnaC B. \& CopăCEsCU S. (1979) Fluturi din România [The Lepidoptera of Romania]. Scrisul Românesc, Craiova, pp. 1-199, pl. 1-90.

STAUDINGER O. (1871) Beschreibung neuer Lepidopteren des europäischen Faunengebiets [Description of new Lepidoptera of the European fauna]. Berliner Entomologische Zeitschrift 14 (1870): 273-330.

Šumpich J. (2011) Motyli Narodnich parků Podyji a Thayatal. Die Schmetterlinge der Nationalparke Podyji und Thayatal [The Lepidoptera of the Naturalparks Podyji and Thayatal]. Sprava Narodniho parku Podyji, Znojmo, $428 \mathrm{p}$.

Šumpich J., Bidzilya O. V., Ponomarenko M. G. (2019) Sophronia salaganella sp. n. from the Russian Altai and new data on Palaearctic Sophronia Hübner, [1825] species (Lepidoptera, Gelechiidae). Zootaxa 4577 (2): 348-360.

Šumpich J., Huemer P., Bidzilya O. (2020) Review of Caryocolum (Lepidoptera: Gelechiidae) from the Russian Altai with description of two new species. Acta Entomologica Musei Nationalis Pragae 60 (1): 65-76. doi: 10.37520/aemnp.2020.004

SzABó E. (1988) Neue Angaben über die Lepidopterenfauna des Rodnaer Gebirges (Nordsiebenbürgische Karpaten, Știol Berg, $1611 \mathrm{~m}$ ) [New contributions to the Lepidoptera fauna of Rodnei Mountains (Carpatians of northern Transylvania, Știol Peak, 1611 m)]. Lucrările celei de-a IV-a Conferințe Naţionale de Entomologie. 29-31 mai 1986, Cluj-Napoca: 89-92.

SzABóKy Cs. (1994) Data to the Microlepidoptera fauna of Transylvania. Folia Entomologica Hungarica 55: 347-354.

Szabóky Cs., ToKár Z., LIŠKa J. \& PAstorális G. (2009) New data to the Microlepidoptera fauna of Hungary, part XII. (Lepidoptera: Lypusidae, Bucculatricidae, Yponomeutidae, Depressariidae, Coleophoridae, Blastobasidae, Autostichidae, Gelechiidae, Tortricidae). Folia Entomologica Hungarica 70: 139-146.

SzÉKELY L. (1995) Lepidopterele din zona subalpină și alpină a Munților Bucegi [The Lepidoptera of the alpine and subalpine zone of the Bucegi Mountains]. Buletin de informare Societatea Lepidopterologică Română 5 (3-4) (1994): 187-200.

SzÉKELY L. (2011) The Lepidoptera of Bucharest and its surroundings (Romania). Travaux du Muséum National d'Histoire Naturelle ,, Grigore Antipa “ 54 (2): 461-512.

SzÉKelY L. \& CERnEA E. (2007) The catalogue of "Mircea Brătăşeanu" Lepidoptera collection. C2 Design, Braşov, pp. 207.

SzÉKEly L., HANESChläger P. \& Görbe R. (1999)
Contribuții la studiul faunei de lepidoptere din Câmpia Munteniei I [Contributions to the study of the Lepidoptera fauna of Munteniei Plane]. Buletin de informare Societatea Lepidopterologică Română 9 (1-4) (1998): 177-186.

SzILÁDY Z. (1915) Magyarországi rovargyüjtésem jegyzéke. IV. Lepidoptera [List of my insect collection in Hungary. IV. Lepidoptera]. Rovartani Lapok 22 (13): $33-43$.

TokÁr Z., LaŠtůvka A., Pastorális G., Šumpich J., ŠTEFANOviČ R. \& ElSNER G. (2015) Nové druhy drobných motýl'ov (Microlepidoptera) pre faunu Slovenska. Records of Microlepidoptera new to the fauna of Slovakia. Folia faunistica Slovaca 20 (1): 37-47.

ToKÁR Z., ŠUMPICH J., LAŠTŮVKA A., LAŠTŮVKA Z., LIŠKA J., ElSNer G., Lendel A., Štefanovič R. \& Richter I. (2021) Species of small moths (Microlepidoptera) new for the fauna of Slovakia. Entomofauna carpathica 33 (2): $1-20$.

VicOL V. (1998) Lista suplimentară de semnalări a microlepidopterelor din România [Additional list of records of Microlepidoptera from Romania]. Buletin de informare Societatea Lepidopterologică Română 8 (3-4) (1997): 189-198.

VICOL V. (2002) Istrianis myricarilla [sic!] (Frey, 1870), gen şi specie noi pentru fauna României (Gelechiinae, Teleiodini) [Istrianis myricarilla [sic!] (Frey, 1870), new genus and species for the fauna of Romania (Gelechiinae, Teleiodini)]. Buletin de informare Societatea Lepidopterologică Română 12 (1-4) (2001): 127-128.

VicoL V. (2005) Contribuţii la cunoaşterea lepidopterelor din România. Specii de microlepidoptere interesante şi cu importanţă zoogeografică [Contributions to the knowledge of the Lepidoptera of Romania. Microlepidoptera of special interest and of zoogeographical importance]. Buletin de informare Entomologică 14-15 (2003-2004): 225-230.

VICOL V. (2006) Dinamica speciilor de micro- și macrolepidoptere de noapte (Lepidoptera) în sezonul cald 2005, localitatea Sânmarghita, județul Mureș, România [The dynamics of the nocturnal Micro- and Macromoths (Lepidoptera) in the worm period of the year 2005 in Sânmarghita, Mureș County, Romania]. Marisia 28: 118-136.

Wegner H. (2011) Die Kleinschmetterlings-Fauna ausgewählter Biotope aus der nordfriesischen Insel Sylt (Lepidoptera) [The Microlepidoptera fauna of selected biotopes of Sylt Island in northern Friesland (Lepidoptera)]. Drosera 2010: 1-44.

Wieser C., RÁKosy L. \& Stangelmaier G. 2000. Schmetterlinge (Lepidoptera). In: RÁKOSY L. \& WIESER C. Das Macin Gebirge (Rumänien, Nord-Dobrudscha). Ein durch hohe Biodiversität gekennzeichnetes Refugium reliktärer Arten. Fauna und Flora, unter besonderer Berücksichtigung der Schmetterlinge und der Vegetationsverhältnisse [Butterflies and Moths (Lepidoptera). In: The Macin Mountains (Romania, northern Dobrudja). A refuge of relict species characterized by high biodiversity. Fauna and flora, with special attention to Lepidoptera and vegetation conditions]. Carinthia II 190/110: 7-116.
Zoltán Kovács

str. Câmpul Mare nr. 133, RO-530240

Miercurea Ciuc, România

E-mail: kovkopp@gmail.com
Sándor KovÁcs

str. Oltului nr. 57 bloc 6 sc. A ap. 6 , RO-520027 Sfântu Gheorghe, România

E-mail: skovacssandor@gmail.com
Received: 22.11.2021

Accepted: 20.12.2021

Published online: 04.02.2022

Article number: ER26202201

doi: 10.24193/entomolrom.26.1 